UNIVERSIDADE DE SÃO PAULO

FACULDADE DE FILOSOFIA, LETRAS E CIÊNCIAS HUMANAS

DEPARTAMENTO DE FILOSOFIA

ALEXANDER GONÇALVES

Estilo e formação na filosofia do jovem Nietzsche

(versão corrigida) 


\title{
ALEXANDER GONÇALVES
}

\section{Estilo e formação na filosofia do jovem Nietzsche}

\author{
(versão corrigida)
}

Tese apresentada ao Programa de PósGraduação da Faculdade de Filosofia, Letras e Ciências Humanas (FFLCH) da Universidade de São Paulo para obtenção do título de Doutor em Filosofia.

Orientadora: Professora Dra. Scarlett Zerbetto Marton. 
Nome: GONÇALVES, Alexander

Título: Estilo e formação na filosofia do jovem Nietzsche

Tese apresentada ao Programa de PósGraduação da Faculdade de Filosofia, Letras e Ciências Humanas (FFLCH) da Universidade de São Paulo para obtenção do título de Doutor em Filosofia.

Aprovado em:

Banca examinadora:

Prof. Dr. Instituição:

Julgamento: Assinatura:

Prof. Dr. Instituição:

Julgamento: Assinatura:

Prof. Dr. Instituição:

Julgamento: Assinatura:

Prof. Dr. Instituição:

Julgamento: Assinatura:

Prof. Dr. Instituição:

Julgamento: Assinatura: 
Aos meus mestres 


\section{AGRADECIMENTOS}

À professora Dra. Scarlett Z. Marton, minha orientadora, primeiramente pela oportunidade de receber a sua orientação e pela oportunidade de participar do GENUSP. Pelos valiosos ensinamentos e pelo exemplo de vida docente e intelectual, exemplo sob o qual continuarei a realizar minha formação.

Ao professor Dr. Wilson Antonio Frezzatti Junior, pela disposição em me auxiliar em mais um trabalho; pela cuidadosa leitura do texto e pelas inestimáveis sugestões proferidas na qualificação deste trabalho e em conversas; pelo exemplo de vida intelectual epela amizade.

Aos professores Dr. Ivo da Silva Junior (UNIFESP), pelas preciosas sugestões dadas na ocasião da qualificação deste trabalho, bem como pela disposição em participar como menbro da banca examinadora.

Ao Dr. Marco Aurélio Werle (USP), Dr. Olímpio José Pimenta Neto (UFOP), Dr. Vladimir Pinheiro Safatle (USP), Dr. Luís Eduardo Xavier Rubira (UFPel), Dr. Miguel Angel de Barrenechea (UNIRIO), Dra. Rosa Maria Dias (UERJ), Dr. Eduardo Nasser (GEN-USP), por aceitarem o convite para examinar este trabalho.

Aos professores do Departamento de Filosofia da FFLCH-USP, Dr. José Carlos Estêvão e Dr. Ricardo Nascimento Fabbrini, pelos valiosos ensinamentos.

Aos colegas do GEN-USP, Braian Matilde, Diana Decock, Éder Corbanezi, Eduardo Nasser, Emmanuel Salanskis, Geraldo Dias, Hélio Simões, João Neto, Lucas,M. Angélica, Rodolfo Ferronato, Marcia Rezende, Saulo Krieger, Stefano Busellato, Tiago Pantuzzi, pelo acolhimento no GEN, pelas inestimáveis contribuições e pelas divertidas conversas.

Aos funcionários do Departamento de Filosofia da FFLCH-USP, de modo especial à secretaria deste departamento.

Aos professores do colegiado de Filosofia da UENP, prof. Dr. Antônio Carlos de Souza; Dr. Calógero Corruba; Ms. Gerson Vasconcelos; Dr. José Carlos da Silva; Dra. Lurdes de Vargas Silveira Schio; Dr. Maurício Saliba; Professora Silvia Borba Zandoná, e aos meus alunos do curso de filosofia da UENP, pelo incentivo e apoio. Em especial, ao prof. Dr. Guilherme Müller Junior, por compartilhar a sua experiência e 
pelas palavras de conforto.

Ao meu amigo Igor A. Paiva, pela ajuda com o abstract.

Aos meus pais(Carlos e Marlene)pelo amor e apoio incondicinal.

À minha esposa Michelle, por todo amor, incentivo, respeito, companheirismo, apoio e principalmente pela paciência e compreensão.

Aos meus filhos, Gustavo e Francisco, pelo estímulo e pela sabedoria como vocês lidaram com tudo isso. Também pela compreensão.

À minha sogra Cledir, pelo apoio, respeito e pela impagável ajuda com os meninos.

Aos meus irmãos (Vera Lúcia, Carlos Alberto, Anna Carolina, Julliano), por todo apoio, respeito e consideração. 
"Se chegasse à nossa cidade um homem aparentemente capaz, devido à sua arte, de tomar todas as formas e imitar todas as coisas, ansioso por se exibir juntamente com os seus poemas, prosternávamo-nos diante dele, como de um ser sagrado, maravilhoso, encantador, mas dir-lhe-íamos que na nossa cidade não há homens dessa espécie, nem sequer é lícito que existam, e mandá-lo-íamos embora para outra cidade, depois de lhe termos derramado mirra sobre a cabeça e de o termos coroado de grinaldas" (Platão, República, 398a).

"Eu gostaria de expulsar de meu Estado ideal os chamados homens cultos, como fez Platão com os poetas: este é meu terrorismo". (Nietzsche, Nachlass/FP 1870-18717[113], KSA 7.164). 


\section{RESUMO}

GONÇALVES, Alexander. Estilo e formação na filosofia do jovem Nietzsche. 2015. 188f. Tese (Doutorado). Faculdade de Filosofia, Letras e Ciências Humanas. Departamento de Filosofia, Universidade de São Paulo, 2015.

Num âmbito geral, nosso objetivo será identificar e analisar as origens da concepção estético-ética de estilo utilizada pelo jovem Nietzsche, bem como analisar a relação entre os conceitos de estilo (Stil) e formação (Bildung) nestes escritos juvenis. Num âmbito específico, o escopo do presente trabalho consiste em mostrar a tese de que o estilo, para o jovem Nietzsche, é tomado como um princípio estético-ético fundamental para que a filosofia realize a sua meta: a formação do homem. Pretendemos mostrar que Nietzsche pensa a ideia da formação do homem em estreita relação com a proposta classicista de uma educação estética através do caráter simples e ingênuo expresso no estilo da arte dos gregos. Retomando a "luta pela formação" (Bildungkampf)iniciada outrora pelos clássicos alemães, Winckelmann, Goethe e Schiller, Nietzsche se colocacomoherdeiro e continuador de uma corrente de pensadores que idealizaram a Grécia clássica como o modelo de cultura e, doravante, utilizaram este ideal como um ponto de fuga para superar a barbárie moderna. É neste registro que Nietzsche pensará o tema do estilo na filosofia, pois, uma vez que a tarefa da filosofia é realizar a formação do homem, o melhor estilo para o discurso filosófico deve ser o estilo simples e ingênuo dos clássicos. Como exemplo de simplicidade e ingenuidade no discurso filosófico moderno, Nietzsche apresenta Schopenhauer, o filósofo educador por excelência.

Palavras-chave: Estilo. Formação. Filosofia. Cultura. Classicismo. 


\begin{abstract}
GONÇALVES, Alexander. Style and formation in young Nietzsche's philosophy. 2015. 188f. Tese (Doutorado). Faculdade de Filosofia, Letras e Ciências Humanas. Departamento de Filosofia, Universidade de São Paulo, 2015.

In a broad context, the main goal of this thesis will be to identify and analyze the origins of aesthetic-ethical conception in style used by the young Nietzsche, as well as to examine the relationship between the concepts of style (Stil) and education (Bildung) in these youthful writings. In a more specific context, the scope of this study is to describe the theory that style for young Nietzsche, is taken as an aesthetic-ethical fundamental principle for philosophy to achieveits goal: the formation of man. Nietzsche thinks the idea of the formation of man closely with the classicist proposal for an aesthetic education through the simple and naïve character expressed in the Greek art style. Returning to the "struggle for formation" (Bildungkampf) started once by German classics, Winckelmann, Goethe and Schiller, Nietzsche stands as an inheritor and continuer of a chain of thinkers who idealized the classical Greece as the model of culture and henceforth used this ideal as a breakout point for overcoming the modern barbarity. It is in this record that Nietzsche will think thetheme of style in philosophy, once, since the purpose of philosophy is to realize the formation of man, the best style for philosophical discourse should be simple and naïve style of the classics. As an example of simplicity and naivety in the modern philosophical discourse, Nietzsche presents Schopenhauer, the philosopher educator par excellence.
\end{abstract}

Keywords: Style. Formation. Philosophy. Culture. Classicism. 


\section{ABREVIATURAS}

As referências feitas às obras de Nietzsche seguem a convenção estabelecida pela edição Colli/Montinari das Obras Completas de Nietzsche, com o acréscimo das siglas em português. Seguimos, assim, o padrão de abreviaturas estabelecido pelos Cadernos Nietzsche - publicação do Grupo de Estudos Nietzsche da Universidade de São Paulo (GEN). A sigla KSA abrevia Friedrich Nietzsche Sämtliche Werke. Kritische Studienausgabe. Hg. Colli und M. Montinari, Berlim, Nova York, Munique: de Gruyter, DTV, 1980, e quinze volumes. Os primeiros algarismos depois de KSA indicam os números dos volumes; os demais remetem à numeração dos fragmentos inéditos.

1. Siglas das obras completas

KSA - Sämtliche Werke: Kritische Studienausgabe

$\mathrm{KGW}$ - Kritische Gesamtausgabe

KSB - Sämtliche Briefe: Kritische Studienausgabe

KGB - Briefwechsel: Kritische Gesamtausgabe

2. Siglas de textos publicados por Nietzsche

2.1.Textos editados pelo próprio Nietzsche

GT/NT - Die Geburt der Tragödie (O nascimento da tragédia)

DS/Co. Ext. I - Unzeitgemässe Betrachtungen. Erstes Stück: David Strauss: Der Bekenner und der Schriftsteller (Considerações extemporâneas I: David Strauss, o devoto e o escritor)

HL/Co. Ext. II - Unzeitgemässe Betrachtungen. Zweites Stück: Vom Nutzen und Nachteil der Historie für das Leben (Considerações extemporâneas II: Da utilidade e desvantagem da história para a vida)

SE/Co. Ext. III - Unzeitgemässe Betrachtungen. Drittes Stück: Schopenhauer als Erzieher (Considerações extemporâneas III: Schopenhauer como educador) WB/Co. Ext. IV - Unzeitgemässe Betrachtungen. Viertes Stück: Richard Wagner in Bayreuth (Considerações extemporâneas IV: Richard Wagner em Bayreuth) MAI/HHI - Menschliches Allzumenschliches (vol. 1) (Humano, demasiado humano 
(vol. 1)

VM/OS - Menschliches Allzumenschliches (vol.2): Vermischte Meinungen (Humano, demasiado humano (vol.2): Miscelânia de opiniões e sentenças)

WS/AS - Menschliches Allzumenschliches (vol.2): Der Wanderer und sein Schatten (Humano, demasiado humano (vol.2): $O$ andarilho e sua sombra)

M/A - Morgenröte (Aurora)

IM/IM - Idyllen aus Messina (Idílios de Messina)

FW/GC - Die fröhliche Wissenschaft (A gaia ciência)

Za/ZA - Also sprach Zarathustra (Assim falava Zaratustra)

JGB/BM - Jenseits von Gut und Böse (Para além de bem e mal)

GM/GM - Zur Genealogie der Moral (Genealogia da moral)

WA/CW - Der fall Wagner (O caso Wagner)

GD/CI - Götzen-Dämmerung (Crepúsculo dos ídolos)

NW/NW - Nietzsche contra Wagner (Nietzsche contra Wagner)

2.2 Textos preparados por Nietzsche para edição

AC/AC - Der Antichrist (O anticristo)

EH/ EH - Ecce Homo (Ecce homo)

DD/ DD - Dionysos-Dithyramben (Ditirambos de Dionísio)

3. Escritos inéditos inacabados

GMD/DM- Das griechische Musikdrama (O drama musical grego)

ST/ST- Sokrates und die Tragödie (Sócrates e a Tragédia)

DW/VD - Dio dionysische Weltanschauung (A visão de mundo dionisíaca)

GG/NP - Die Geburt des tragischen Gedankens ( $O$ nascimento do pensamento trágico)

BA/EE - Über die Zukunft unserer Bildungsanstalten (Sobre o futuro de nossos estabelecimentos de formação)

PHG/FT - Die Philosophie im tragischen Zeitalter der Griechen (A filosofia na idade trágica dos gregos)

WL/VM - Über Wahrheit und Lüge im aussermoralischen Sinn (Sobre verdade e mentira no sentido extramoral)

\section{Cursos}


VPP/FP - Die vorplatonischen Philosophen (Os filósofos préplatônicos)

EPD/IDP - Einführung in das Studium der platonischen Dialoge (Introdução aos

diálogos platônicos)

EKP/EFC - Enzyklopädie der klassischen Philologie (Enciclopédia da filologia

clássica)

5. Fragmentos Póstumos:

Para a citação dos fragmentos póstumos, utilizaremos a sigla Nachlass/FP seguido do ano e dos algarismos arábicos referentes ao fragmento.

6. Traduções.

Nas citações da obra de Nietzsche, adotamos, sempre que possível, a tradução deRubens Rodrigues Torres Filho publicada no volume das Obras Incompletas (SãoPaulo: Editora Nova Cultural, 2000). O recurso a essa tradução é indicado pela siglaRRTF, que abrevia o nome do tradutor. Nas citações de fragmentos póstumos, utilizamos como fonte de consulta a tradução espanhola de J. B. Llinares, Jesús Conill, Diego Sánchez Meca e Luis E. de Santiago Guervós publicado pela editora Tecnos, Madrid. Não obstante, as traduções destes fragmentos são de nossa responsabilidade. Nas citações referentes ao Curso de retórica utilizaremos a tradução portuguesa de Tito Cardoso e Cunha publicado pela editora Passagens, Lisboa. O recurso a essa tradução será indicado pela sigla T.C. 
SUMÁRIO

INTRODUÇÃO. 14

CAPÍTULO 1. ESTILO E FORMAÇÃO: A CAMINHO DE UMA CONCEPÇÃO ESTÉTICO-ÉTICA DE ESTILO.

CAPÍTULO 2. BÁRBAROS ILUSTRADOS: O ESTILO COMO ANTÍDOTO CONTRA A BARBÁRIE. .53

CAPítulo 3. O ESTILO E A EDUCAÇÃo ESTÉTICA DO HOMEM NO JOVEM NIETZSCHE: DA FORMAÇÃO TRÁGICA À FORMAÇÃo RETÓRICA .91

CAPÍTULO 4. O ESTILO NA FILOSOFIA: UM INSTRUMENTOPARA A FORMAÇÃO DO HOMEM. .128

CONCLUSÃO. 171

REFERÊNCIAS .175 


\section{INTRODUÇÃO}

No que diz respeito à filosofia de Nietzsche, o tema do estilo não é um tema menor. Amplo e diversificado, o conjunto dos comentários que tratam desse assunto atestam a sua relevância e, por conseguinte, sua importância para todos os que pretendem ler o autor de Assim falava Zaratustra. Grande foi o interesse dos intérpretes em encontrar um sentido filosófico para a peculiar estilística nietzschiana, sobretudo, para os textos a partir de Humano, demasiado humano (1876), primeira obra aforística do filósofo alemão ${ }^{1}$. Por outro lado, pouco foi o interesse em averiguar, na obra de Nietzsche, como ele mesmo pensou a relação entre estilo e filosofia. Contudo, no tocante aos escritos nietzschianos, a preocupação com a temática do estilo precede em muito a redação de Humano, demasiado humano e, como atestam fragmentos póstumos da década de 1870, antes mesmo da publicação de sua primeira obra, $O$ nascimento da tragédia (1872), o filósofo já se ocupava com o tema do estilo na filosofia. Como se pode observar num fragmento póstumo deste período, Nietzsche pensa este tema sob a perspectiva da valoração do problema estilístico. O filósofo escreve:

O estilo nos escritos filosóficos.

A valoração do problema estilístico depende do que se exija ao filósofo.

Se o fim é o puro conhecimento científico ou se se quer divulgar conhecimentos filosóficos.

Se a finalidade é a instrução [Belehrung]ou a edificação, etc. [...] (Nachlass/FP 1869, 75[20], KWGI. 5. 241).

Com efeito, o melhor estilo deve ser aquele que melhor corresponde à respectiva exigência. Neste caso, é necessário indagar acerca dessa exigência, isto é, questionar acerca da tarefa do filósofo e, por conseguinte da meta da filosofia: se é produzir puro conhecimento científico à instrução do indivíduo, ou divulgar conhecimentos filosóficos tendo em vista a sua edificação.

Em sua Terceira Consideração Extemporânea, acerca do papel do filósofo, Nietzsche escreve: "Para mim, um filósofo é importante na justa medida em que está em condições de dar exemplo (Beispiel). Não há dúvida alguma de que, mediante o

\footnotetext{
${ }^{1}$ Sobre a concepção nietzschiana de estilo nas obras tardias, Cf. NEHAMAS, A. Nietzsche: life as literature. Cambridge/Massachusetts: Harvard University Press, 1985; ITAPARICA, André. Nietzsche: estilo e moral. São Paulo: Discurso Editorial, 2002.
} 
exemplo, pode arrastar atrás de si povos inteiros; a história da Índia, que é praticamente a história da filosofia hindu, o prova"(SE/Co. Ext. III $\S 3$, KSA 1.350). Como indivíduo modelar, o filósofo é um educador (Erzieher) por excelência. Contudo, a tarefa de educar, na acepção nietzschiana, é algo radicalmente diferente e, num certo sentido, oposto à de instruir.

Para o jovem Nietzsche, educar não é um processo que ocorre pela via teórica da ilustração (Aufkärung) ${ }^{2}$, mas que se dá através do contato com modelo exemplar, o próprio educador, sendo assim, ele acontece por uma via ao mesmo tempo estética e ética. Neste sentido, num póstumo do verão de 1872 - começo de 1873, Nietzsche afirma:

a formação (Bildung) não é necessariamente conceitual (begriffliche), mas sobretudo é intuitiva (anschauende), e elege corretamente (...) A educação (Erziehung) de um povo para a formação é essencialmente o acostumar-se a bons modelos (gute Vorbilder) e uma formação de necessidades nobres" (Nachlass/FP 1872 - 1873, 19 [299], KSA, 7.511)

Uma vez que não se trata de um processo de ilustração do homem, a educação não tem como meta a erudição do indivíduo e o acúmulo de saberes científicos, mas sim a edificação estética e moral do indivíduo, o que significa, em última análise, realizar a sua plena formação ${ }^{3}$. Na busca pela formação, cabe ao indivíduo encontrar o seu educador e formador (Bildner), aquele que, em última análise, é o seu descobridor e libertador. Nietzsche escreve:

[...] descobre o verdadeiro sentido originário e a matéria fundamental do teu ser, algo que é totalmente ineducável e imodelável, mas que em todo caso também é dificilmente acessível e que está atado e paralisado: os únicos que podem ser

\footnotetext{
${ }^{2}$ Utilizaremos a palavra "ilustração" como correspondente em nosso vernáculo para o termo alemão Aufkärung. Sobre o conceito de Aufkärung, seguimos a interpretação de Rubens Rodrigues Torres Filho em que escreve: "Luzes (Século das): com essa metáfora de claridade (Lumières, Iluminismo, Enlightenment, Ilustración, Aufklärung), o pensamento europeu do século XVIII formou sua autoimagem, caracterizada pela confiança no poder da luz natural, da razão, contra todas as formas de obscurantismo (TORRES FILHO, 1987, p. 84).

${ }^{3}$ No sentido aqui empregado, os conceitos nietzschianos de formação (Bildung) e de educação (Erziehung) se encontram particularmente imbricados. Enquanto o termo Erziehung alude a um processo pedagógico ao qual uma pessoa ou grupo se submete a outro seguindo o aspecto normativo de um modelo determinado, a Bildung diz respeito ao processo de autoformação do indivíduo. Neste sentido, Erziehung e Bildungsão termos convergentes na medida em que a autoformação indicada pela Bildung requer um modelo a ser fornecidopela Erziehung.
} 
seus educadores são teus libertadores. E este é o segredo de toda formação [Bildung] (SE/Co. Ext. III § 1, KSA 1.337).

Assim, com o exemplo do educador, o educando tem a possibilidade de vislumbrar e de acessar o seu ser mais íntimo e aquilo que ele verdadeiramente é. Desta perspectiva, a educação (Erziehung) tem a ver com as ideias de liberdade e emancipação. Segundo Nietzsche, ela "é libertação (Befreiung), limpeza de todas as ervas daninhas, dos escombros, dos vermes que querem atacar os ternos gérmenes das plantas"(SE/Co. Ext. III $\S 1$, KSA 1.337). Haja vista o filósofo como o educador nietzschiano por excelência, sua tarefa consiste em emancipar o indivíduo de todas as amarras que o impedem de se elevar até si mesmo (Selbst). Nietzsche escreve: "teu verdadeiro ser não se encontra oculto no fundo de ti, mas imensamente elevado acima de ti, ou pelo menos acima do que considera habitualmente como o seu eu" (SE/Co. Ext. III $\S 1$, KSA 1.337).

Completa a tarefa da libertação, o filósofo educador passa a operar numa via propositiva, pois, uma vez emancipado, o indivíduo se encontra livre para realizar de modo pleno a sua formação. É neste sentido que o filósofo educador é também o formador do homem, pois é por intermédio de sua vida e obra exemplar que o educando encontra os meios para realizar em sua vida uma transfiguração (Verklärung) ${ }^{4}$, ou seja, aperfeiçoar a sua natureza de modo a fazer de si mesmo um todo harmônico e coeso, eis o sentido de uma autêntica formação. Em relação a este caráter propositivo do filósofo educador, Nietzsche escreve: “(...) a tarefa de sua educação consistiria melhor, a meu ver, em remodelar (umbilden) o ser humano inteiro em um sistema solar e em um sistema planetário dotados de vivos movimentos" (SE/Co. Ext. III $§ 2$, KSA 1.341).

Com efeito, a filosofia vem a ser o meio pelo qual o filósofo realiza sua tarefa educativa visando à formação do homem como uma totalidade, como um sistema solar em que todas as forças girem em torno e em prol de uma força central ${ }^{5}$; ou, nos termos da antiga retórica, totum ponere ${ }^{6}$ : fazer do homem um todo; uma unidade a partir da relação harmônica entre as partes. Mas porque é o indivíduo uma parte de um todo

\footnotetext{
${ }^{4}$ Cf. SE/Co. Ext. III $\S 4$, KSA 1.363 .

${ }^{5}$ Cf. SE/Co. Ext. III $§ 2$, KSA 1.341.

${ }^{6} \mathrm{~A}$ noção de totum ponere é proveniente da estética clássica, particularmente das artes poética e retórica. Nesta acepção, a realização do belo na obra de arte depende da capacidade do artista em criar uma totalidade, uma obra de arte em que as partes estejam ordenadas de modo a compor um todo harmônico. O ideal clássico dototum ponere influenciará de maneira decisiva a crítica nietzschiana aos escritores alemães de sua época e, de modo particular,ao teólogo e escritor David Strauss em sua Primeira consideração extemporânea. Sobre a noção de belo no classicismo antigo, Cf. Tringali, 1993, p. 540.
} 
social, também deve alcançar a plena harmonia com as outras partes de modo a formar uma cultura (Kultur) una e coesa. Desse modo, embora o conceito de formação tenha a ver diretamente com o indivíduo, com o seu aperfeiçoamento estético e moral, não deixa de se comunicar com o todo social e a cultura à qual pertence. Assim, ainda que os conceitos de formação e cultura apareçam num primeiro momento como conceitos antagônicos, já que com o primeiro Nietzsche geralmente se refere ao indivíduo e com o segundo à coletividade, esta oposição é apenas secundária. A formação e a cultura, para o jovem Nietzsche, são instâncias em permanente comunicação, pois para que haja uma autêntica formação do indivíduo é necessário que o mesmo esteja inserido em uma autêntica cultura, ou pelo menos tenha sido formado segundo os preceitos da mesma ${ }^{7}$.

Ora, se a tarefa do filósofo é educar o homem e não apenas instruí-lo, e se esta educação não se dá via exemplos concretos, mas sim de forma como via de apreensão estética, então o estilo sob o qual o discurso filosófico se apresenta corresponderá à finalidade do filósofo educador, ou seja, tem em vista à formação do homem e não à divulgação de conhecimentos científicos. Em última instância, o filósofo deverá promover a transfiguração do homem assim que o formar como uma totalidade em si mesmo, mas que se reconhece como parte de um todo cultural. Por isso, o nexo que é estabelecido por Nietzsche entre o estilo e a filosofia não pode ser analisado de modo satisfatório senão à luz dos temas da formação e da cultura.

É na Primeira Consideração Extemporânea que os conceitos de estilo, formação e cultura aparecem pela primeira vez relacionados na obra de Nietzsche. O polêmico ensaio contra David Strauss apresenta uma definição de cultura (Kultur) como se fosse a "unidade de estilo artístico" (Einheit des künstlerischen Stiles) no âmbito das manifestações da vida de um povo ${ }^{8}$. Imbricados deste modo, os conceitos de estilo e cultura recebem uma determinação recíproca, uma vez que já não é possível pensar um sem pensar o outro ${ }^{9}$. Dessa perspectiva, se não há unidade estilística na vida do povo alemão, logo não há, segundo Nietzsche, uma cultura original alemã ${ }^{10}$, pois o que o

\footnotetext{
${ }^{7}$ Neste sentido, concordamos com a posição de Wotling quando este escreve: “a Cultur não é Bildung. Mas os dois conceitos não se opõem simplesmente como uma determinação individual e subjetiva a uma determinação coletiva, embora a Bildung remeta sobretudo à formação intelectual de um indivíduo particular, e a Cultur se aplique, geralmente, em compensação, a um povo ou a um grupo humano relativamente grande. O caráter relativamente secundário dessa oposição se mostra particularmente, quando se considera o exemplo de Goethe, celebrado por Nietzsche não pela qualidade de sua Bildung, mas, ao contrário, porque ele encarna, enquanto indivíduo singular, a Cultur" (WOTLING, 2013, p. 55).

${ }^{8}$ Cf. DS/Co. Ext. I § 1, KSA 1.159.

${ }^{9}$ Sobre esta relação de interdependência entre os conceitos de Kultur e Stil, Cf. GENTILE, 2010, p. 56.

${ }^{10} \mathrm{Cf}$. DS/Co. Ext. I § 1, KSA 1.159.
} 
povo alemão denomina cultura é exatamente o seu oposto, a barbárie (Barbarei), ou seja, a ausência de um estilo ou a confusão caótica de todos os estilos ${ }^{11}$. Ora, se o alemão moderno é bárbaro é porque não tem uma autêntica cultura e, enquanto vive em meio à barbárie, não pôde se formar senão como um bárbaro.

O alvo dos ataques nietzschianos é a pseudoformação filisteia predominante na Alemanha pós-Revolução Francesa, um tipo de "formação" que valoriza o acúmulo de saber e a erudição do indivíduo em detrimento de sua formação estética. Para Nietzsche, os responsáveis por este tipo de formação e, consequentemente, pela instalação da barbárie na Alemanha moderna são os filisteus da formação (Bildungsphilister) ${ }^{12}$ e as instituições de formação (Bildungsanstalten) alemãs. Contra este tipo de formação teórica e erudita, mas também contra o modelo de educação propagado pelas instituições de ensino alemãs de seu tempo, Nietzsche apresenta a hipótese de uma formação intuitiva ${ }^{13}$, um tipo de formação que tem no ideal classicista da educação estética do homem o caminho para a formação plena do indivíduo e instituição uma autêntica cultura alemã.

Ao assumir uma posição contrária às tendências educacionais vigentes em sua época, que tomavam a ilustração como instrumento para a formação do ser humano, Nietzsche se alinha à concepção de educação estética do homem do classicismo alemão que aposta na arte como via segura para a educação do homem. Educar a sensibilidade com a arte é construir o alicerce necessário para que o homem se forme como um ser harmônico e coerente, tanto consigo mesmo quanto com a sociedade, pois como afirma Schiller: "Somente o gosto permite harmonia na sociedade, pois institui harmonia no indivíduo" (SCHILLER, 2002, p. 140). Educado pela arte, o homem supera seus anseios imediatos e realiza sua verdadeira formação, como um cultivo de si mesmo, mas sem perder de vista o todo. O sentido desta afirmação Goethe revela a Eckermann na

\footnotetext{
${ }^{11}$ Cf. DS/Co. Ext. I § 1, KSA 1.159.

${ }^{12}$ Por utilizarmos "formação" como correspondente em nosso vernáculo ao termo alemão Bildung (ver nota 1), justificamos nossa opção pela expressão "filisteus da formação" para traduzir o termo nietzschiano Bildungsphilister. Em textos posteriores, Nietzsche tecerá algumas considerações acerca da origem e do uso deste termo. Em Ecce homo, num capítulo designado à primeira extemporânea, o filósofo escreve: "a palavra Bildungsphilister ficou na linguagem a partir do meu escrito" (EH/EH As extemporâneas § 2, KSA 6. 317). No conhecido prólogo de 1886 à Humano, demasiado humano II, o filósofo escreve: "reivindico a paternidade da expressão Bildungsphilisterque se usa e abusa atualmente" (HHII, prólogo, KSA 2.370). Em nota à tradução de Ecce homo para o idioma inglês, Walter Kaufmann afirma que a palavra Bildungsphilister teria sido já utilizada anteriormente por Gustav Teichmüller (1832 - 1888), no entanto, na opinião do pesquisador americano, a reivindicação nietzschiana é legítima pois, segundo Kaufmann, Nietzsche não diria tudo isso caso se recordasse de que a cunhagem do termo é de Teichmüller (Cf. Nietzsche, F. Ecce homo. Trad. Walter Kaufmann, New York: The Modern Library, 1992).

${ }^{13}$ Cf. Nachlass/FP $1872-1873,19$ [299], KSA, 7.511.
} 
seguinte sentença: "cada um deve a rigor formar-se como um indivíduo à parte, mas deve procurar alcançar a noção do que todos representam em conjunto" (GOETHE, 1950, p. 31).

Mas afirmar que a educação pela arte é o caminho para uma formação de um homem pleno e harmônico, consigo e com a sociedade, traz à pessoa mais problemas do que soluções, pois como romper a arte produzida por uma sociedade bárbara pode realizar a transfiguração do homem? Dessa forma, como romper o ciclo da barbárie, ou seja, como realizar uma formação autêntica e deixar de ser bárbaro enquanto vive numa constituição bárbara?

Da perspectiva do classicismo alemão, que, como se procurará mostrar, é a perspectiva assumida ocasionalmente pelo jovem Nietzsche, o único meio de romper este ciclo é formar o alemão por outra cultura, realmente autêntica. Dito de outro modo, se o alemão não tem uma autêntica cultura, então deve buscar em outra os elementos para a sua formação e, por conseguinte, superar a condição de bárbaro. É na cultura grega, de modo particular na arte dos gregos antigos, que o classicismo alemão buscou os subsídios necessários para a formação do alemão moderno, bem como para a realização de sua cultura como unidade e totalidade.

Para o jovem Nietzsche, Winckelmann, Goethe e Schiller foram os primeiros homens a iniciar, na Alemanha moderna, um processo de luta pela formação (Bildungskampf), uma vigorosa luta para aprender com os gregos o verdadeiro sentido da formação ${ }^{14}$. Esses clássicos alemães são, portanto, os guias seguros para conduzir o alemão moderno à nostálgica terra da $\mathrm{Grécia}^{15}$ e realizar uma autêntica formação e uma verdadeira cultura alemã. Não obstante, não é toda produção artística que concorre para promover a educação estética do homem, mas um tipo de produção específico da Grécia que Winckelmann designou como clássica e para o qual Goethe e também Schiller forjaram o conceito de estilo $(\mathrm{Stil})^{16}$, modo de designar o grau supremo atingido pela obra de arte clássica, cujas características principais são a simplicidade e a ingenuidade de estilo.

É a partir deste ideal estético e ético do classicismo alemão que Nietzsche pensará a filosofia. Neste sentido, uma vez que a meta do filósofo é a formação do

\footnotetext{
${ }^{14} \mathrm{Cf}$. GT/NT §20, KSA 1.129.

${ }^{15} \mathrm{Cf}$. BA/EE, II KSA, 1.672.

${ }^{16}$ Cf. GOETHE, J.W.Imitação simples da natureza, maneira, estilo. In: Escritos sobre arte. Trad. Marco Aurélio Werle. São Paulo: Humanitas, 2008; cf. SCHILLER, F. Kallias ou sobre a beleza.Trad. Ricardo Barbosa. Rio de Janeiro: Jorge Zahar Editor, 2002.
} 
homem, o estilo do discurso filosófico deve corroborar para o seu fim, o que significa ser simples e ingênuo, tal como aquele que os clássicos alemães viram nos gregos. Simplicidade de estilo (Simplicität des Stil) e ingenuidade serão, portanto, as principais características do escritor clássico, aquele que cria um todo (totum ponere) a partir do caos dos elementos linguísticos e rítmicos; mas também serão, segundo Nietzsche, os indícios da genialidade, uma vez que o gênio é o único que tem o privilégio de se expressar com simplicidade, naturalidade e ingenuidade ${ }^{17}$. Schopenhauer, para o jovem Nietzsche, é o gênio ingênuo de seu tempo. Comparado a Kant, afirma Nietzsche num póstumo de 1868-1869, Schopenhauer é ingênuo (naïf) e clássico (klassisch) ${ }^{18}$; é o filósofo de uma "reanimada classicidade" e de uma "grecidade alemã"19. Dotado de capacidade para o simples e ingênuo, Schopenhauer é filósofo educador (Erzieher) por excelência, pois em seu estilo a sua filosofia realiza a sua principal meta, a formação humana.

Entender a escrita de Nietzsche como um instrumento de formação do homem e construção da cultura é se perguntar pelos sentidos estético e ético de seu estilo. De fato, a peculiar forma com que Nietzsche apresentou sua filosofia foi uma das causas que levaram diversas correntes político-ideológicas do século passado a se apropriarem de suas ideias, como foi o caso, por exemplo, da apropriação feita pelo Nazismo alemão, do Fascismo italiano e de pensadores anarquistas no Brasil ${ }^{20}$. Esse fato levou alguns intérpretes a tomá-lo como um dos precursores da Revolução Conservadora na Europa $^{21}$. Autores como Ernst Jünger ${ }^{22}$ chegam a apontar Nietzsche, juntamente com Schopenhauer e Hölderlin, como os faróis dessa revolução. Assim, seja pelo emprego de formas literárias como o aforismo e a poesia, seja pelo tom incisivo de suas sentenças, o pathos moral dos escritos nietzschianos provocou grande inquietação, tanto

\footnotetext{
${ }^{17}$ DS/Co. Ext. I, 10, KSA 1.216.

${ }^{18}$ Nachlass/FP 1868 - 1869, 75[20], KWG I. 5. 241.

${ }^{19}$ Nachlass/FP 1868 - 1869, 75[20], KWG I. 5. 241.

${ }^{20}$ Referimo-nos a intelectuais como José Oiticica (1882-1957) e Maria Lacerda de Moura (1887-1945).

${ }^{21}$ A imagem de Nietzsche como um antecipador da Revolução Conservadora foi amplamente difundida a partir da obra de Armin Mohler: Die Konservative Revolution in Deutschland 1918 - 1932, que na terceira parte intitulada "Imagens-guia" é dedicada ao pensamento de Nietzsche. Influenciando autores como Adriano Romualdi e Giorgio Locchi, a obra de Mohler repercute ainda hoje na leitura de Nietzsche, como, por exemplo, no Nietzsche enquanto um "rebelde aristocrata" do escritor italiano Losurdo. Sobre a interpretação de Nietzsche como um precursor da Revolução conservadora, cf. LOSURDO, Domenico.Nietzsche, il ribelle aristocrático. Torino: Bollati Boringhieri, 2002.Acerca da recepção italiana do pensamento de Nietzsche, Cf. MARTON, S. (org.). Nietzsche pensador mediterrâneo: a recepção italiana. São Paulo: Discurso Editorial, 2013.

${ }^{22}$ Ernst Jünger (1895 - 1998), escritor, poeta e novelista alemão, foi soldado durante a Primeira Grande Guerra. Sobre a interpretação de Nietzsche como um dos "faróis" da Revolução conservadora cf. JÜNGER, E. Scritti politici e di guerra 1919-1933. Gorizia: LEG, 2003.
} 
no mundo da arte quanto no da política do século XX, de modo a se mostrar um importante instrumento de articulação entre essas duas esferas.

Já nas primeiras décadas do século XX, Nietzsche é recebido não como filósofo, mas como um literato, por artistas e escritores politicamente engajados como Gabriele d'Annunzio ${ }^{23}$ e Giovani Papini ${ }^{24}$. Partidários da ideologia fascista, estes intelectuais italianos encontraram nos escritos nietzschianos uma fonte de inspiração poética para seus ideais éticos e políticos, ideais reconhecidamente aristocráticos. Todavia, classificar Nietzsche como um poeta e um literato não é um privilégio da recepção artística, uma vez que esta posição também encontrará alguns adeptos no campo da filosofia.

É o caso, por exemplo, da interpretação de W. Dilthey que, em Die Typen der Weltanschauung und ihre Ausbildung in den metaphysischen Systemen (1919), situa o nome de Nietzsche junto ao nome de artistas e escritores como Byron, Leopardi, Carlyle, Wagner, Tolstoi e Maeterlinck, todos eles expoentes daquilo que Dilthey denomina "filosofia da vida" - tendência literário-filosófica que se afirma na modernidade com o suposto ocaso do pensamento metafísico e a crença no fim da filosofia científica. Dilthey sustenta que o estilo poético do autor de Zaratustra exerceu uma influência arrebatadora sobre a juventude. O filósofo escreve: "Sua influência era fortalecida por sua conexão natural com a poesia; pois também os problemas da poesia são problemas vitais. Seu procedimento chega a ser o de uma experiência metódica da vida, que rechaça formalmente todos os supostos sistemáticos” (DILTHEY, 1998, p. 124).

De modo semelhante, Bertrand Russell, em seu History of Western Philosophy (1945), considera que, devido ao seu peculiar trabalho estilístico, Nietzsche deve ser considerado mais como um literato e menos como um filósofo. Russell escreve: "Nietzsche, apesar de professor, foi antes um literato do que um filósofo acadêmico" (RUSSELL, 1947, p.788). Para Russell, isso é o que justifica o fato de que as posições

\footnotetext{
${ }^{23}$ D'Annunzio (1863-1938), poeta e dramaturgo italiano que teve uma conturbada carreira política marcada por ideais nacionalistas e aristocráticos. D'Annunzio exerceu forte influência sobre Benito Mussolini que, em certa ocasião, manifestou o desejo de proclamá-lo o "João Batista do Fascismo". A influência que o pensamento político de Nietzsche exerceu sobre d'Annunzio pode ser notada em suas obras Il Trionfo della Morte (1894), Le Vergini delle Rocce (1896), Il Fuoco (1900). Em 1906, d'Annunzio publicou um livro de poesias, intitulado In Memoriam Friedrich Nietzsche.

${ }^{24}$ Giovanni Papini (1881-1956), jornalista, ensaísta, escritor e poeta italiano, foi um dos principais ativistas da cultura italiana entre o Futurismo e o Fascismo. Papini fundou e dirigiu influentes revistas italianas como Il Leonardo e La Voce. Sua interpretação de Nietzsche pode ser percebida em obras como Il crepuscolo dei filosofi (1906).
} 
éticas e políticas aristocráticas de Nietzsche exercessem uma grande influência, sobretudo, no cenário artístico e cultural do mundo moderno. Russell escreve: "é inegável que Nietzsche teve uma grande influência, não entre os filósofos técnicos, mas entre pessoas de cultura literária e artística. É preciso também reconhecer que suas profecias para o futuro, até agora, mostraram-se mais certas do que as dos liberais ou socialistas" (RUSSELL, 1947, p.794). A impossibilidade de se estabelecer uma aristocracia de nascença, afirma Russell (1947, p. 798), leva a crer que o pensamento ético e filosófico de Nietzsche visava a uma aristocracia totalitária, conforme estabelecida em organizações como o Fascismo e o Nazismo.

De certo modo, o pathos moral do estilo nietzschiano foi o que levou Alfred Bäumler ${ }^{25}$ - ideólogo filosófico oficial de Hitler - a considerar o filósofo da "vontade de potência" como um arauto do Nazismo. Bäumler vê o estilo aforismático de Nietzsche como uma forma absolutamente coerente para expressar a profunda radicalidade de seu pensamento, um pensamento guiado pelas forças irracionais da vida e não pelas leis da lógica: "ele sentiu com clareza aguda que sua posição era infinitamente audaciosa, infinitamente mais perigosa do que aquela da Igreja do século XVIII e mais ousada que a dos seus adversários racionalistas" (BÄUMLER apud LUKÁCS, 1958, p.318). Ao considerar os aforismos nietzschianos isoladamente, a interpretação de Bäumler procura circunscrever o pensamento de Nietzsche no âmbito político e ideológico do Terceiro Reich.

Para Georg Lukács, que considera o Nietzsche de Bäumler como o verdadeiro Nietzsche, o aspecto estilístico da filosofia de Nietzsche revela com nitidez as suas tendências políticas reacionárias. Em Die Zerstiirung der Vemunf (1952), o filósofo húngaro afirma que o conteúdo e o método reacionários da filosofia nietzschiana se ligam intimamente com a sua principal forma expressiva, o aforismo. Diferente da exposição sistemática, esta forma literária permite a revisão permanente dos conteúdos, o que, da perspectiva de Lukács, torna o texto vulnerável às necessidades interpretativas vigentes. Lukács escreve: "tal forma literária possibilita o elemento da mudança no interior do contexto da sua influência duradoura" (LUKÁCS, 1958, p. 278). Para o autor de História e consciência de classe, o estilo aforismático se torna politicamente

25 Entre os trabalhos que Bäumler escreveu sobre Nietzsche, destacam-se Nietzsche, der Philosoph und Politiker. Leipzig: Reclam, 1931; Nietzsches Philosophie in Selbstzegunissen. Ausgewählt und herausgegeben von Alfred Baeumler. Leipzig: Reclam, 1931 e Bachofen und Nietzsche. Zurich: Verlag der Neuen Schweizer Rundschau, 1929. 
perigoso quando "uma mudança na interpretação torna-se uma necessidade social como, por exemplo, na época imediatamente preparatória para o hitlerismo, e, como ainda hoje, depois da queda de Hitler"26 (LUKÁCS, 1958, p. 278).

No intuito de proteger o texto nietzschiano de interpretações equivocadas, sobretudo a literária e a política, alguns autores buscaram amenizar o entusiasmo em torno do estilo nietzschiano ao propor uma metodologia de leitura que ultrapasse a superfície do texto, o seu estilo, e retire de suas profundezas a sua verdadeira filosofia, o seu sentido oculto. Dessa forma, Karl Jaspers defende um tipo de interpretação do texto nietzschiano que "consiste em penetrá-lo, em vez de subsumi-lo" (JASPERS, 2000, p. 14). Segundo Jaspers, o princípio sobre o qual esta interpretação autêntica deve ser construída é a linguagem: "Nietzsche se situa nessa origem onde fundamento e limites se objetivam na linguagem; pensamento e imagem, sistema dialético e poesia tornam-se aqui expressões do mesmo valor" (JASPERS, 2000, p. 16). Com efeito, o filósofo alemão considera o estilo como um fator secundário e de pouca relevância para o texto na medida em que, independente da forma expressiva, nele subsiste um sentido absoluto, o próprio ser: "Nietzsche é o homem que, por lidar com a totalidade, pôde verdadeiramente e essencialmente comunicar o aprendizado e a compreensão que ele tem do ser" (JASPERS, 2000, p. 16).

Ao seguir este mesmo intuito de blindar o texto nietzschiano das interpretações equivocadas, a leitura de Heidegger também pode ser caracterizada pelo seu pouco interesse pelo aspecto estilístico. Enquanto defende a tese de que "a filosofia propriamente dita de Nietzsche é deixada para trás como uma obra 'póstuma', não publicada" (HEIDEGGER, 2007, p. 11), o pensador alemão tende a valorizar os escritos póstumos em detrimento dos textos publicados. Tal posicionamento deixa clara a sua opinião em relação ao lugar secundário que o estilo ocupa na leitura do texto nietzschiano, obra publicada por Nietzsche se comunica como se pretendeu, seja qual for o estilo utilizado. Nesse caso, Heidegger subtrai o aspecto estilístico dessa filosofia em troca da tarefa de encontrar as intenções ocultas e reconstruir o legítimo pensamento de Nietzsche a partir das não publicadas. Neste sentido, pouco importa o estilo de uma obra, o que vale, em última análise, é o pensamento que ela oculta: “em verdade, a obra

\footnotetext{
${ }^{26}$ Sobre a interpretação lukacsiana de Nietzsche, cf. MONTINARI, M. Equívocos Marxistas. Cadernos Nietzsche. São Paulo, n.12, p. 33-52, 2002.
} 
capital planejada $A$ vontade de potência é uma obra tão poética quanto Zaratustra é uma obra de pensamento" (HEIDEGGER, 2007, p. 14).

No mesmo ímpeto, Karl Löwith proporá um tipo de leitura que compreenda o estilo aforismático e fragmentário nietzschiano em um sistema, pois, para Löwith, a filosofia de Nietzsche "é um sistema em aforismos" (LÖWITH, 1991, p. 19). Guardada as devidas particularidades, afirma-se que os procedimentos metodológicos de Jaspers, Heidegger e Löwith visam à mesma meta: superar de algum modo o obstáculo do estilo e encontrar o sentido oculto do texto nietzschiano.

Em oposição a essa busca do pensamento único de Nietzsche operada pela hermenêutica de Jaspers e Heidegger, Gilles Deleuze, em Pensamento nômade (1972) resgata o sentido político do estilo para a filosofia de Nietzsche. Deleuze entende que a forma peculiar da escrita nietzschiana, de modo particular o estilo aforismático, consiste numa máquina de guerra (machine de guerre) com a qual o filósofo alemão pretende tornar incodificável sua própria língua ${ }^{27}$. O filósofo francês argumenta: "quanto à Nietzsche, ele vive ou se considera polonês em relação ao alemão. Apodera-se do alemão para montar uma máquina de guerra que vai fazer passar algo que é incodificável em alemão. É o estilo como política" (DELEUZE, 1985, p. 59). Com o aforismo, afirma Deleuze, a filosofia nietzschiana escapa dos três grandes instrumentos de codificação da sociedade, "a lei, o contrato e a instituição" (DELEUZE, 1985, p. 58), pois em sua escrita e de seu pensamento, Nietzsche persiste "numa tentativa de decodificação, não no sentido de uma decodificação relativa que consistiria em decifrar os códigos antigos, presentes ou futuros, mas numa decodificação absoluta - fazer passar algo que não seja codificável, embaralhar todos os códigos" (DELEUZE, 1985, p. 59).

\footnotetext{
${ }^{27}$ Em Pourparlers, Deleuze define o conceito de machine de guerre nos seguintes termos: "Definimos a 'máquina de guerra' como um agenciamento linear construído sobre linhas de fuga. Nesse sentido, a máquina de guerra não tem, de forma alguma, a guerra como objeto; tem como objeto um espaço muito especial, espaço liso, que ela compõe, ocupa e propaga. O nomadismo é precisamente essa combinação máquina de guerra-espaço liso." (DELEUZE, 1990, p. 50). Como "máquina de guerra", o aforismo nietzschiano se revela para Deleuze como uma exterioridade que, embora possa ser apropriada pelo Estado, não pode ser reduzida aos seus desígnios político-ideológicos. Neste sentido, Zourabichvili explica: "A tese da exterioridade da máquina de guerra significa ao mesmo tempo que não se concebe o Estado sem uma relação com um fora de que ele se apropria sem poder reduzí-lo (a máquina de guerra institucionalizada como exército), e que a máquina de guerra se relaciona de direito, positivamente, com um agenciamento social que, por natureza, nunca se fecha sobre uma forma de interioridade. Esse agenciamento é o nomadismo: sua forma de expressão é a máquina de guerra, sua forma de conteúdo - a metalurgia; o conjunto relaciona-se a um espaço dito liso" (ZOURABICHVILI, 2004, p. 34).
} 
Em consonância como o pensamento de Deleuze, Jacques Derrida (2010, p. 30) sustenta, contra a tese de que o texto de Nietzsche oculta um pensamento autêntico e um sentido absoluto, que o estilo é um instrumento que emancipa o texto de sua conexão metafísica com $a$ verdade, $o$ sentido ou $o$ conteúdo. Nesse sentido, o estilo é algo que, por tornar o discurso incaptável, promove um excesso de liberdade e um acréscimo de democracia. Em Politiques de l'amitié, o filósofo da desconstrução escreve:

A cada instante o discurso é levado ao limite, à beira do silêncio: transporta-se para além de si mesmo. É arrebatado pela extrema oposição, a saber, pela alteridade, pela hipérbole que o compromete num sobrelanço infinito (mais livre que a liberdade do espírito livre, melhor democrata que a multidão dos democratas modernos, aristocrata entre todos os democratas, mais futuro e futurista que o moderno), arrebatado pelo talvez que vem indecidir o sentido em cada momento decisivo (DERRIDA, 2003, p. 56).

Ao considerar o texto nietzschiano como passível de infinitas interpretações, como um espaço democrático para o encontro com a alteridade, Derrida vê na escrita nietzschiana a possibilidade de se compreender a ética e a política sob uma nova perspectiva, a que prescinde de qualquer fundamento metafísico absoluto, bem como de um discurso lógico e racional. Desse modo, afirma Derrida, o estilo nietzschiano fere uma ideia tradicional de comunicação como está prevista, por exemplo, na noção habermasiana do agir comunicacional: "Tudo isto (este acréscimo de democracia, este excesso de liberdade, esta reafirmação do porvir) não é lá muito propício, não há dúvida, à comunidade, à comunicação, às regras e máximas de um agir comunicacional" (DERRIDA, 2003, p. 56).

Certamente, a peculiar arte de estilo de Nietzsche serviu de pretexto para as apropriações literárias e políticas de seu pensamento. No entanto, embora tais interpretações - como é o caso das interpretações Nazista e Fascista - reconheçam a potência moral e política do estilo nietzschiano, elas não se preocuparam em analisar detidamente as considerações morais e políticas da obra de Nietzsche. Enquanto se desvincula forma e conteúdo, estes intérpretes desprezaram o último e sobrevalorizaram a primeira de modo a adequarem o texto nietzschiano aos seus interesses políticos e 
ideológicos. Ao entender o estilo aforismático de Nietzsche como uma forma literária perigosa e reacionária, uma vez que se torna passível de revisão constante, logo coerente com os ideais políticos totalitários, a reflexão de Lukács continua a priorizar a forma do discurso em detrimento do seu conteúdo porque trabalha ainda com a distinção entre estas duas partes.

A separação entre forma e conteúdo é ainda mantida nas interpretações protecionistas, como a de Jaspers e Heidegger, porém, de modo contrário a essas interpretações, neste caso o que se priorizou foi o conteúdo. Ao tentarem proteger o texto de Nietzsche de tais usurpações políticas e más interpretações, tanto Heidegger quanto Jaspers optaram por despotencializar o potencial ético e político de sua escrita por desconsiderar a importância de sua forma e sobrevalorizando sobretudo o conteúdo, isto é, o "sentido" do texto. Assim, o maior ganho da interpretação libertária francesa pode ter sido a compreensão de que, em Nietzsche, forma e conteúdo não se distinguem.

Para Deleuze, e também para Derrida, não há mais hiato entre signo e significado; entre palavra e sentido, entre texto e interpretação. No entanto, ainda que a interpretação deleuziana vise a recuperar o potencial político do estilo nietzschiano quando aponta o estilo aforismático de Nietzsche como um meio de resistência e subversão contra os instrumentos de codificação da sociedade, esta interpretação valoriza apenas o aspecto negativo, isto é, a face crítica e desconstrutiva da escrita de Nietzsche. É certo que a face demolidora da escrita de Nietzsche tem uma importância relevante para sua filosofia, porém, ao negligenciar o aspecto propositivo de seu estilo, Deleuze parece negligenciar o poder edificador desta escrita e também desta filosofia. Neste sentido, a interpretação de Derrida parece estar mais atenta, à medida que toma o procedimento crítico e demolidor operado pelo estilo de Nietzsche como o momento inaugural para a proposição de um novo modo de comunicação. Isso torna possível pensar uma nova modalidade ética e política destituída de metafísica. No entanto, Derrida não procura inspecionar, no próprio texto de Nietzsche, as condições que ele próprio estabelece para tal construção.

Em meio a estas questões, este trabalho se propõe a tarefa de buscar, na obra de Nietzsche, um conceito propriamente nietzschiano de estilo para compreender de que modo o filósofo alemão pensou a relação entre estilo e filosofia. É no contexto de sua filosofia juvenil, sob a influência de preceitos estéticos, éticos e políticos do classicismo 
alemão, que Nietzsche iniciará a sua reflexão sobre o conceito de estilo. Assim, pensado no âmbito maior para discutir sobre a formação e a educação humana, o estilo surge como um elemento fundamental para a que a filosofia atinja a sua meta suprema: realizar a formação plena do homem e, por conseguinte, a edificação da cultura.

No âmbito de perseguir os objetivos propostos, a pesquisa incidirá sobre a totalidade dos textos do período de juventude, ou seja, os escritos redigidos até o ano de 1875, tanto os textos publicados quanto os fragmentos póstumos, contudo serão priorizadas as obras que estão diretamente relacionadas com o tema. Destarte, em $O$ nascimento da tragédia, bem como nos escritos preparatórios, e em A visão dionisíaca do mundo, avaliar-se-á de que modo Nietzsche esboçou uma primeira teoria do estilo ainda sob os preceitos da metafísica schopenhaueriana. Nos textos posteriores à primeira obra, em particular as Extemporâneas I, II, III, em Sobre o futuro de nossas instituições de formação e em póstumos deste período, procurar-se-á analisar a relação que o conceito de estilo (Stil) estabelece com os conceitos de formação (Bildung) e de cultura (Kultur). No Curso de retórica, em Sobre o pathos da verdade e Verdade e mentira no sentido extra-moral, será o estatuto estético e retórico da linguagem para, em seguida, com o auxílio dos póstumos do caderno 19, dedicados ao Philosophenbuch, fundamentar-se-á a hipótese acerca do estatuto poético da filosofia no jovem Nietzsche.

Obras de outros filósofos também serão utilizadas no intuito de complementar a discussão. Neste sentido, utilizar-se-ão textos de Winckelmann, como as Reflexões sobre a imitação das obras gregas na pintura e escultura, os Ensaios sobre filosofia e história da arte; de Goethe, como o ensaio A imitação simples da natureza, maneira, estilo, Conversas com Eckermann e Os anos de aprendizado de Wilhelm Meister; e de Schiller, como Kallias ou sobre a beleza e A educação estética do homem numa série de cartas, para fundamentar a hipótese acerca das posições classicistas de Nietzsche no que diz respeito ao seu modo de pensar a relação entre estilo e filosofia.

A metodologia empregada para a leitura dos textos Nietzschianos foi a de leitura imanente, o que significa que não se utilizou o recurso às fontes. Quando se recorreu a texto de outros autores, como Winckelmann, Goethe e Schiller, isto não se deu no sentido de apresentar o pensamento de Nietzsche por meio de suas fontes, mas reconstruir o percurso de uma história das ideias e de uma tradição de pensadores alemães ao qual Nietzsche, ao menos em sua juventude, parece ter herdado e continuado. Com o objetivo de aprofundar a leitura do texto nietzschiano, recorreu-se ao método genético no intuito de reconstituir e compreender o percurso dos conceitos de 
estilo e formação no texto nietzschiano. Por fim, a abordagem filológica também se mostrou como um recurso eficaz e necessário em momentos pontuais da leitura.

Para o desenvolvimento dessa reflexão acerca da relação entre estilo e filosofia no pensamento juvenil de Nietzsche, dividiu-se este trabalho em quatro capítulos. Na medida em que a relação entre o estilo e a filosofia, no pensamento do jovem Nietzsche, se dá à luz da noção de formação, no primeiro capítulo o ponto de partida consistirá em reconstituir historicamente a relação entre a concepção de estilo e a de formação até o momento histórico em que surgem as considerações do jovem Nietzsche sobre este tema. Esse resgate histórico, por permitir uma melhor compreensão do pensamento de Nietzsche sobre este tema, mostra-se fundamental para análise que virá a seguir nos próximos capítulos. Para tanto, far-se-ão com alguns preliminares semânticos acerca dos referidos conceitos para que, em seguida, seja averiguada a origem e o desenvolvimento da concepção de estilo desde a antiga retórica até o contexto político e cultural da Alemanha do século XVIII, mediante a reflexão de Winckelmann, Goethe e Schiller, o conceito de estilo passa a ser entendido em estreita relação com a ideia de formação clássica do homem.

No segundo capítulo, analisar-se-á a relação entre estilo e formação no percurso que vai de Winckelmann a Goethe e Schiller. Mostrar-se-á como o estilo tem sido um tema recorrente no pensamento estético-político do classicismo alemão na medida em que se apresenta como um elemento necessário para uma nova concepção de educação e formação do homem. Será avaliado o estatuto da "volta aos gregos", conforme empreendida pelo historicismo estético de Winckelmann, pelas intuições artísticas de Goethe e pela reflexão estético-pedagógica de Schiller. Por fim, considerar-se-ão os pontos centrais do ideal classicista de educação estética do homem, uma educação fundamentada nos princípios da estética clássica que tem como objetivo servir de instrumento para a formação plena do homem e superação da barbárie alemã. A análise da relação entre os conceitos de estilo e formação nesses autores do classicismo alemão se mostra necessária na medida em que o jovem Nietzsche se coloca como um continuador daquilo que chamou como "luta pela formação", um movimento estéticomoral em prol da formação do homem alemão que teria sido iniciado por eles.

Após apresentar a relação entre estilo e formação no pensamento destes autores classicistas, será analisado, no terceiro capítulo, de que modo estes conceitos se relacionam na filosofia do jovem Nietzsche. Nos textos juvenis, analisar-se-á o percurso da relação entre o estilo e a formação, primeiramente em $O$ nascimento de tragédia e 
em A visão dionisíaca do mundo, textos ainda fundamentados por uma metafísica de artista wagneriana e schopenhaueriana. Na tentativa de mostrar que, num primeiro momento, embora Nietzsche empreenda a "luta pela formação" alemã ao modo dos clássicos alemães, esta luta não será travada segundo os princípios da estética do classicismo alemão, uma vez que, segundo Nietzsche, eles se limitaram a considerar apenas uma das faces da arte dos gregos, a apolínea, uma vez que se desconsidera o papel fundamental do elemento dionisíaco. Ainda neste capítulo, a análise recairá sobre os textos posteriores ao período de redação de $O$ nascimento da tragédia, momento em que Nietzsche apresenta a relação entre estilo e formação a partir de uma abordagem retórica da linguagem que culminará numa concepção estética da linguagem.

No quarto e último capítulo, pretender-se-á mostrar de que modo Nietzsche retoma algumas noções fundamentais da estética do classicismo alemão, como os ideais de ingenuidade e simplicidade, para compor a sua ideia de formação estética do homem a partir de uma relação íntima com a literatura e com a língua. Neste sentido, mostrarse-á, por intermédio da crítica nietzschiana à linguagem, à literatura e aos meios educacionais de seu tempo, quais são os pontos fundamentais da oposição nietzschiana àquilo que designou como a formação de seu tempo. Ao analisar a relação entre estilo e formação de um ponto de vista da língua e da linguagem, abrir-se-á caminho para a reflexão que virá em seguida acerca do sentido formador que o estilo tem para a filosofia. Assim, a intenção principal neste capítulo, consistirá em demonstrar a tese de que o estilo é um elemento fundamental para que a filosofia realize a sua meta principal, a formação do homem. Ao retomar os princípios estéticos do classicismo alemão, será apresentada a ideia de que o estilo simples e ingênuo dos clássicos é, para Nietzsche, o melhor estilo para que a filosofia atinja a sua meta formadora. Por fim, ver-se-á como a ingenuidade e a simplicidade do estilo de Schopenhauer fazem dele o filósofo educador por excelência.

Embora os temas do estilo e da formação tenham sido amplamente analisados e discutidos pelos estudiosos da filosofia nietzschiana, acreditar-se-á que a proposta de abordar esses dois conceitos de maneira imbricada, bem como de reconstituir a gênese dessa relação na filosofia juvenil de Nietzsche, apresenta-se como uma proposta original e, desse modo, como uma reflexão que possa contribuir para lançar luz a uma das questões mais instigantes da filosofia de Nietzsche, aquela que pergunta sobre o sentido filosófico do seu próprio estilo. 


\section{CAPÍTULO 1 \\ ESTILO E FORMAÇÃO \\ A caminho de uma concepção estético-ética de estilo}

De um modo geral, Nietzsche utiliza a palavra estilo (Stil) numa diversidade de acepções. Pode-se detectar um uso normativo do termo, por exemplo, quando se fala em "verdadeiro estilo" (wahren Stils), “estilo ideal” (idealen Stil), ou (Nachlass/FP 18691872, 9[90], KSA 7.306) ou "doutrina do estilo" (Lehre vom Stil) (Nachlass/FP 18751876, 8[4], KSA 8.129). Poderá ser encontrado também num sentido próximo de uma concepção artística que, desde o cinquecento italiano até a teoria da arte de seu tempo, tomou por estilo a maneira (maniera) ou forma peculiar na produção artística de um indivíduo ou de um povo ${ }^{28}$. É neste sentido que o filósofo se refere a um "estilo de Strauss" (Stil des Strauß) (DS/CO $§ 11$, KSA 1.120), um "estilo artístico de Ésquilo" (den künstlerischen Stil des Aischylos) (Nachlass/FP 1872-1873, 19 [22], KSA 7.423); ou ainda um estilo grego (griechische Stil) (Nachlass/FP 1874-1874 26[15], KSA 7.581), um estilo alemão (Deutscher Stil) (Nachlass/FP1869-1872, 16[2], KSA 7.393) ou "estilo nacional" (nationalen Stile) (DS/Co. Ext. I § 11, KSA 1.220). Em numerosas e diversificadas ocorrências, o termo aparece num registro classificatório e, neste sentido, vem acompanhado de uma variedade de adjetivos como "estilo elevado" (hohe Stil) (Nachlass/FP 1872-1874, 21[2], KSA 7.523) ou "grande estilo" (grossen Stile) $\left(\mathrm{SE} /\right.$ Co. Ext. III $\S 4$, KSA 1.363) ${ }^{29}$. Em passagens menos frequentes, nota-se que a palavra estilo é utilizada num sentido paralelo ao de uma concepção iluminista, que o compreende como a expressão do próprio pensamento de um indivíduo singular. No seguinte fragmento póstumo da época da redação do seu Zaratustra, Nietzsche parece expressar tal concepção de estilo nos seguintes termos: "Melhorar o estilo - isso significa melhorar o pensamento - e nada além disso!" (Nachlass/FP 1882 - 1884, 12[1], KSA 10.383$)^{30}$.

\footnotetext{
${ }^{28}$ Outras expressões utilizadas neste sentido, como "estilo latino", "estilo francês", "estilo asiático", são recorrentes nos escritos nietzschianos de juventude, tanto póstumos como publicados.

${ }^{29}$ No que tange os escritos juvenis, póstumos e publicados, há uma quantidade considerável de estilos mencionados por Nietzsche, além das que já nomeamos aqui, por exemplo: "grande estilo", "estilo elevado", "estilo seco", "estilo hierático", "estilo simples", "estilo jornalístico", "estilo velado", "estilo de movimento", "belo estilo", "mau estilo", "estilo falado", "estilo naturalista", "estilo do intelecto", "estilo da vontade", "estilo do pensamento impuro", etc.

${ }^{30}$ A despeito deste paralelo, a noção nietzschiana de pensamento e de linguagem, neste período de sua escrita, difere radicalmente do racionalismo dos autores do Iluminismo e da Aufklärung, o que exige uma
} 
Além desta multiplicidade de sentidos, ainda é possível detectar no corpus nietzschiano uma última acepção de estilo, a estético-ética. Ao levar em consideração os textos juvenis, como A Visão Dionisíaca do Mundo, pode-se verificar esta acepção quando o filósofo alemão se propõe a avaliar a cultura trágica dos gregos a partir dos dois "estilos antagônicos" (Stilgegensätze) (DW/VD §1, KSA, 1.553) da arte grega, a saber, Apolo e Dioniso; ou, por exemplo, quando num póstumo de 1869 o filósofo condiciona o valor do estilo à ideia de edificação do homem ${ }^{31}$. Ao operar neste último registro, Nietzsche retoma uma tradição de pensadores do classicismo alemão que, desde as investigações históricas e estéticas de J.J.Winckelmann, passou a compreender o estilo artístico dos povos antigos como um instrumento hermenêutico para a compreensão e avaliação da cultura destes povos, mas também como um instrumento pedagógico destinado à formação (Bildung) do homem.

O escopo deste capítulo inicial consiste em apresentar as origens históricofilosóficas da concepção estético-ética de estilo no pensamento alemão dos séculos XVIII e XIX, momento em que o tema do estilo é pensado em relação íntima com os temas da formação e da educação. Compreender o desenvolvimento histórico da relação entre os conceitos de estilo e formação se faz necessário na medida em que se entende o jovem Nietzsche como continuador desta acepção estético-ética de estilo. Assim, este capítulo se iniciará com alguns preliminares semânticos acerca do termo estilo, desde sua gênese no âmbito da antiga tradição retórica até a sua acepção moderna. Em seguida, procurar-se-á averiguar em que circunstâncias se dá a conexão entre este conceito e o pensamento da Bildung na Alemanha dos séculos XVIII e XIX.

A palavra estilo provém do latim stilus (punção). É errônea a afirmação de alguns autores ${ }^{32}$ de que a palavra latina stilus tenha alguma relação etimológica com o termo grego stylos( $\sigma \tau \tilde{U} \lambda o \varsigma)$, que significa "coluna" ${ }^{33}$. Segundo $\mathrm{Soca}^{34}$, a origem mais

interpretação deste fragmento à luz desta diferença, o que foge do escopo de nosso trabalho haja vista que nosso trabalho incide sobre a concepção de estilo nietzschiana nos textos juvenis.

${ }^{31}$ Cf. FP V, 75[20] fevereiro de 1868-outubro de 1869.

${ }^{32} \mathrm{Cf}$. BAYARD, E. L'artde reconnaitreles styles, p.10.

${ }^{33}$ Em A Latin Dictionary, organizado por LEWIS, C.T.; SHORT, C, Oxford: Clarendon Press, 1879, a relação entre os termos stylos e stilus parece ter sido fruto de uma confusão entre os latinos que, por influxo da língua grega, acabaram por adotar a grafia desta utilizando o " $y$ " no lugar do "i". Trata-se, 
remota que se conhece do termo stilus se encontra provavelmente no sânscrito tigmas, "pontiagudo", que gerou o termo indo-europeu steig, "cravar", "puncionar", e deste o substantivo grego stigma, "estigma". Do substantivo stigma derivou-se o verbo grego stizein, "pintar", "perfurar com um instrumento pontiagudo", donde provém o termo latino stimulus, "aguilhão", e, desse, o termo stilus. Entre os antigos, contudo, a utilização da palavra se dá de forma diversificada.

Num amplo sentido, stilus significava uma haste pontiaguda em forma de lança ou estaca: "extra vallum stili caeci" ("fora dos muros, estilos escondidos") (Auctor Belli Africani, 31, 5apud LEWIS, SHORT, 1958, p.1759) ${ }^{35}$. Já no âmbito da agricultura, o termo stilus designava uma ferramenta pontiaguda utilizada para liberar as plantas de vermes ou de brotos, enquanto promovia o seu fortalecimento. Nesse mesmo sentido, a palavra stilus também servia para designar o caule ou a haste de determinadas plantas, como aspargos: "Omnis autem nux unam radic emmittit, et simplici stilo prorepit" ("Mas cada noz enviou uma raiz, e o estilo facilmente se arrastou") (Columella, Res Rustica, 5.10.13apud LEWIS, SHORT, 1958, p.1759).

No tocante às letras, stilus designava um pequeno instrumento metálico em forma de haste. Com uma das extremidades pontiaguda e a outra achatada na forma de uma espátula, o stilus era uma espécie de estilete com a qual os antigos gravavam por incisão caracteres sobre uma tábua encerada: "effer cito stilum, ceram et tabellas et linum" (trazei logo estilo, cera, tábua e linho) (Plauto,Bacch. 4, 4, 64, apud LEWIS, SHORT, 1958, p.1759). Diante da necessidade de se apagar um erro ou mesmo um escrito na íntegra, alisava-se a cera com a extremidade chata do stilus fazendo "tabula rasa": "saepe stilum vertas, iterum quae digna legi sint, (...)" ("retornou o estilo, refazendo coisas dignas de serem lidas (...)" (Cícero,Verr. 2, 2, 41, § 101) ${ }^{36}$.

Foi por metonímia que o termo stilus, utilizado para designar o instrumento da escrita, passou a designar, entre os antigos retóricos, o modo de escrever ou falar

portanto, de uma aproximação meramente formal, uma vez que etimologicamente os termos não se relacionam. A língua inglesa e a francesa conservaram este equívoco gráfico no termo style.

${ }^{34}$ Cf. SOCA, 2004, p. 86.

${ }^{35}$ As citações referentes a essas obras foram retiradas de A Latin Dictionary, organizado por LEWIS, C.T.; SHORT, C.(Oxford: Clarendon Press, 1879). No entanto, preferimos apontar as referências das obras latinas para as quais adotamos a convenção dos Estudos Clássicos, apondo o nome latino da obra abreviado após o autor, livro e/ou parágrafo das edições consultadas. A tradução do latim para o português é de nossa responsabilidade.

36 Traduzido de CICERO. M. Tullius. The Orations of Marcus Tullius Cicero.Trad. C. D. Yonge. London: George Bell \& Sons, 1903. 
(modus scribendi/dicendi) $^{37}$. Cícero ocasionalmente empregou o termo neste sentido, como lemos na seguinte sentença: "stilus optimus et praestantissimus dicendi effector ac magister" ("O estilo é o melhor e mais eminente dos artesãos e mestres do bem dizer") (Cícero, de Or. 1, 33, 150, apud LEWIS, SHORT, 1958, p.1759). Nesse seguimento, em De vitis Caesarumde Suetônio lemos: "affectationeobscurabatstilum" (“a afetação obscurece o estilo") (Suetonius. Aug. 85, apud LEWIS, SHORT, 1958, p.1759); e ainda: "stilidicendiduosunt: unusestmaturusetgravis, alterardenserectusetinfensus, etc" ("Há dois estilos de falar: um é maduro e sério, o outro é ardente, elevado e hostil, etc") (Suetonius. Tib. 70apud LEWIS, SHORT, 1958, p.1759).

Com efeito, a transposição do termo estilo para o campo das letras traz consigo o problema da valoração estilística. Ao ser o estilo o modus scribendi/dicendi, é necessário que o escritor ou orador questione acerca do melhor estilo para a sua arte: se este deve ser sóbrio ou afetado; sério ou ardente. Em vista disto, o termo estilo recebe da antiga retórica um acento normativo na medida em que, para os antigos retóricos, estabelecer um estilo significa selecionar e organizar os elementos discursivos de modo a compor um discurso que deve ser conveniente a uma determinada ocasião. Para tanto, tais elementos discursivos, como as palavras, o ritmo, a entonação, o gesto e a postura do orador, devem estar submetidos às normas e leis rígidas da estética clássica. Associado à ideia de conveniência ${ }^{38}$, o estilo constituirá um dos pontos centrais da doutrina latina do decorum.

\footnotetext{
${ }^{37}$ Philip Sohm (1999, p. 104), em seu artigo 'Maniera' and the absent hand: avoiding the etymology of style, afirma que Quatremère de Quincy $(1755$ - 1849) foi o primeiro autor a problematizar o estilo como metonímia. A fim de introduzir sua discussão sobre o estilo, Quincy teria entendido a produção estilística como um processo metonímico em que uma atividade mecânica é identificada com uma atividade mental. Em outros termos, o estilo, para Quincy, significa a arte de expressar ideias através de sinais de escrita (Cf. SOHM, P. Maniera and the absent hand: Avoiding the etymology of style. RES: Anthropology and Aesthetics, Harvard, n.36, p.100-124, Autumn, 1999.).Ainda neste sentido, no âmbito da Encyclopédie ou Dictionnaire raisonné des sciences, des arts et des métiers(1751-1772), encontramos a afirmação de que a palavra estilo (style), para os antigos, se referia ao objeto utilizado para a escrita, mas que no contexto moderno teria recebido uma nova acepção denotando não mais o referido objeto, mas a maneira de expressar os pensamentos de forma oral ou escrita. (Cf.DIDEROT, D; D' ALEMBERT, 1751-1765, p. 551). Anos depois, a Encyclopédie Panckoucke(1788-1825) apresenta o seguinte argumento sobre o estilo: "por metonímia é aplicada à operação da mente na arte de expressar seus pensamentos com os sinais de escrita, a ideia de a operação mecânica da mão ou instrumento que traça estes sinais" (Encyclopédie Méthodique, p. 410).Sobre o conceito de estilo como metonímia, ver também o verbete "Stil", in: Historisches Wörterbuch der Philosophie, organizado por J. Ritter e K. Gründer, Bd.10, Basel: Schwabe 1989, p. 150 - 159.

${ }^{38} \mathrm{~A}$ tradução brasileira utiliza o termo "conveniência" como correlato ao termo latino decorum. Cf. ARISTÓTELES; HORÁCIO; LONGINO. A Poética clássica. Trad. Jaime Bruna. São Paulo: Cultrix, 1997; TRINGALI, D. A arte poética de Horácio. São Paulo: Musa Editora, 1993.
} 
De acordo com o Oxford Latin Dictionary, o advérbio latino decore deriva do adjetivo decorus, cuja raiz é o substantivo decor e o verbo decet, verbo utilizado sempre na terceira pessoa e que significa "estar de acordo com os padrões aceitos de gosto e conduta; ser apropriado; ser correto"39. Segundo Tringali (1993, p. 55), o termo decorum é o correspondente latino para a palavra grega prépon, termo que foi haurido de Aristóteles e que significava, ao mesmo tempo, o que é belo e o que convém. Entre os antigos retóricos, o decorum, ou doutrina da conveniência, consiste num instrumento racional que visa à realização do belo na obra de arte ${ }^{40}$. Sobre a noção de decorum, Tringali afirma: "É a virtude suprema da criação artística. É a ética da estética. A própria natureza dita o que convém em arte. A conveniência estatui o que convém e o que não convém e, como conseqüência, o que se deve ou não fazer" (TRINGALI, 1993, p. 55).

A obediência ao decorum, portanto, revela a presença de uma ética no processo de produção do estilo, já que esta deve ser regulada de acordo com a ideia de conveniência. Isto significa que os elementos do discurso, como o ritmo e as palavras, devem ser selecionados de acordo com o gênero, o tema e, sobretudo, com o espectador a que será dirigido. Em sua Arte Poética, Horácio constata que Homero perceberá que o verso que convém à narração de grandes feitos próprios da epopeia é o hexâmetro. Por outro lado, Arquíloco ${ }^{41}$ teria criado o metro jâmbicono intuito de expressar os assuntos coléricos. Horácio afirma ainda que, "a um tema cômico repugna ser desenvolvido em versos trágicos" (Horácio, Ars Poetica, 89) ${ }^{42}$. No que diz respeito à poética clássica, a poesia se encontra necessariamente condicionada a um conjunto de regras e princípios racionais e objetivos, condição sem a qual não se realiza o objetivo, o belo. Desta perspectiva, se não há respeito às regras e leis da arte, isto é, ao decorum, não há beleza, tampouco há poesia ou poeta ${ }^{43}$.

De Aristóteles a Platão, de Horácio a Quintiliano, a noção de belo que impera nas artes poética e retórica do antigo classicismo é o "belo matemático" ou "pitagórico",

\footnotetext{
${ }^{39}$ Cf. PALMER, R. C. Oxford Latin Dictionary. Oxford: Clarendon Press,1968, p.551.

${ }^{40}$ Cf. TRINGALI, D. A arte poética de Horácio. São Paulo: Musa Editora, 1993.

${ }^{41}$ Natural de Paros, o poeta Arquíloco viveu em meados do século VII a. C. e é tido como o criador da elegia e do metro jâmbico. Já na antiguidade, Arquíloco gozava de um prestígio semelhante ao de Homero. Sobre a constituição rítmica da poesia de Arquíloco, cf. ANTUNES, L.B.C. Ritmo e sonoridade na poesia grega antiga. São Paulo: Humanitas/FAPESP, 2011.

${ }^{42}$ In: ARISTÓTELES; HORÁCIO; LONGINO. A Poética clássica. Trad. Jaime Bruna. São Paulo: Cultrix, 1997, p. 57.

${ }^{43}$ Sobre a condição do poeta, Horácio escreve: "Se não posso nem sei respeitar o domínio e o tom de cada gênero literário, por que saudar em mim um poeta? Por que a falsa modéstia de preferir a ignorância ao estudo?" (Horácio, Ars Poetica, 86-88).
} 
ideal de beleza que se caracteriza pelas ideias de unidade, harmonia, lúcida ordem e justa medida ${ }^{44}$. Grosso modo, na acepção clássica, o belo está relacionado à habilidade do artista para construir uma totalidade (totum ponere) ${ }^{45}$, ou seja, sua capacidade para ordenar as partes de uma obra de modo a conceber um todo harmônico. O decorum é o suporte para que se desenvolva, na obra de arte, relação de caráter necessário entre as suas partes ${ }^{46}$ de modo a realizar a beleza. Concebida assim, a beleza tende a agradar ${ }^{47}$ na medida em que se apresenta ao público como uma totalidade equilibrada e harmônica. Ao ser o decorum a condição para a realização do belo na obra de arte, cabe ao artista a disciplina e o estudo rigoroso deste que é o critério fundamental para que sua arte obtenha o reconhecimento junto ao público.

Daniel Kapust considera o decorum como “(...) a pré-condição do êxito da persuasão e é medido pela resposta de aprovação de um auditório" (KAPUST, 2012, p. 266). Deste modo, o decorum se apresenta como um conjunto de normas estilísticas que ajustam o discurso a uma ocasião particular. Este decorum está arraigado a um communis sensus que opera ao mesmo tempo sobre o nível racional, linguístico, emocional e estético $^{48}$, e que se encontra no corpo do escritor ou orador e nas paixões expressas através dele com a finalidade de agradar o seu público. Sobre a expectativa do orador ou escritor em agradar ao público, Horácio em Arte Poética escreve:

Não basta serem belos os poemas; têm de ser emocionantes, de conduzir os sentimentos do ouvinte aonde quiserem. $\mathrm{O}$ rosto da gente, como ri com quem ri, assim se condói de quem chora; se me queres ver chorar, tens de sentir a dor primeiro tu; só então, meu Télefo, ou Peleu, me afligirão os teus infortúnios; se declamares mal o teu papel, ou dormirei, ou desandarei a rir" (Horácio, ArsPoetica, 100-105).

Nesse fragmento, é notória a forma como o poeta procura equilibrar os elementos estéticos da obra de modo a realizar a beleza, porém sem perder de vista o sentimento. Ora, se o belo é um princípio estético racional e universal, falará à razão e ao êthos do espectador, ao passo que a emoção, elemento idiossincrático, é o que desperta o pathos. Neste sentido, em Acerca do Orador, Cícero sugere que um estilo

\footnotetext{
${ }^{44}$ Cf. Tringali, 1993, p. 54.

${ }^{45} \mathrm{Cf}$. nota 06.

${ }^{46} \mathrm{Cf}$. Tringali, 1993, p. 55.

${ }^{47}$ Cf. Tringali, 1993, p. 54.

${ }^{48}$ Cf. KAPUST, D. Cicerón: El decorum y La moralidad de La retórica. Trad. Christian Felipe Pineda Pérez. Praxis Filosófica, Cali, v.35, p. 257-282, julho/dez. 2012, p. 266.
} 
tênue é sempre adequado para cultivar o êthos, ao passo que um estilo veemente se mostra apropriado para excitar o pathos ${ }^{49}$. Associado ao princípio do decorum, o classicismo antigo desenvolveu três possibilidades estilísticas: o estilo simples, o estilo elevado ou sublime e o estilo médio ${ }^{50}$.

Na Enciclopédia (1751-1765, p. 551), as três espécies de estilos desenvolvidas pelos antigos retóricos são caracterizadas do seguinte modo: a) o estilo simples, marcado pela pureza, clareza e ausência de ornamentação, é o mais apropriado para cartas e para fábulas; b) o estilo elevado ou sublime, que faz reinar a nobreza, a dignidade e a magnitude em uma obra, em que todos os pensamentos são nobres e elevados e que todas as expressões são graves, sonoras e harmoniosas; c) o estilo médio, que consiste em um meio entre o estilo simples e o elevado, pois tem a nitidez do primeiro, mas recebe todos os ornamentos e cores do segundo. Embora distintos, os três estilos podem conviver em uma mesma obra, já que na medida em que segue o decorum, o estilo deve ser estabelecido de acordo com as circunstâncias.

No que diz respeito às artes poética e retórica da antiguidade clássica, a eleição por um determinado estilo varia de autor para autor. Segundo Kapust (2012, p. 267), Cícero defende o uso dos três modos estilísticos, porém cada um deles deve estar devidamente adequado às circunstâncias. Para Tringali (1993, p. 65), Horácio se inclina decisivamente para o estilo médio, pois, conforme exigem as circunstâncias, o estilo médio tende para o simples ou para o sublime. No entanto, o poeta adverte contra os perigos do estilo simples cair no rasteiro e do sublime cair no empolado. Longino, por sua vez, escreverá um tratado no qual defenderá o uso da paixão e do entusiasmo no discurso, elementos característicos do estilo elevado ou sublime. Contudo, na medida em que no classicismo predomina o ideal do belo, ou seja, a realização da harmonia e da ordem na obra de arte, o estilo sublime é tolerado apenas como um fenômeno eventual e ainda assim de forma moderada, ao depender menos do engenho do artista do que do caráter normativo do decorum ${ }^{51}$. Submetido à doutrina do decorum, o estilo constitui, para os antigos retóricos, um cânone formal, ou seja, um sistema de leis e normas pelo qual o artista, escritor ou orador pode expressar o seu pensamento.

\footnotetext{
${ }^{49}$ Cf. Kapust, 2012, p. 266.

${ }^{50} \mathrm{Na}$ Enciclopedia lemos: "as palavras são escolhidas e arranjadas segundo as leis da harmonia e do número, relativamente à elevação ou à simplicidade do assunto que tratamos, isso resulta no que chamamos de estilo" (DIDEROT; D’ ALEMBERT, 1751-1765, p. 551).

${ }^{51}$ Cf. Tringali, 1993, p. 65.
} 
É a partir do Renascimento italiano que o termo stile assumirá cada vez mais uma nova faceta em que se inicia um processo de radical transformação que encontrará o seu apogeu séculos mais tarde na era do iluminismo. Neste sentido, os artistas e teóricos renascentistas iniciarão uma ruptura com o passado de norma, regra e prescrição do stile e passarão a utilizar cada vez o termo para designar o modo próprio ou pessoal de um artista realizar a sua obra. É também neste período que o emprego da palavra estilo ultrapassará definitivamente o âmbito das artes literárias e se estenderá para outras artes, como as artes plásticas, a arquitetura e a música ${ }^{52}$.

No que tange o universo das artes plásticas, afirma Sauerländer (1983, p. 257258), o uso moderno da palavra stileparece não ter ocorrido antes do cinquecento. Em Il Cortegianode Castiglione, encontra-se uma sentença que confirma a hipótese de que na Itália de 1530 a palavra stilejá era utilizada para se referir a outras artes, de modo particular às artes plásticas. Mas o que mais surpreende é que a ideia de estilo, neste período, ultrapassa o registro do decorum, das normas e leis objetivas que passam a se referir também ao modo particular com que o artista realiza a sua obra. Em Il Cortegiano, Castiglione associa o termo estilo com individualidade dos pintores:

Considere que, na pintura, são excelentes Leonardo da Vinci, Mantegna, Raphael, Michelangelo, e Giorgio de Castel Franco, e ainda assim eles são todos diferentes um do outro, de modo que em nenhum deles parece faltar coisa alguma na maneira, porque se conhece queem seu estilo cada um é perfeito (Castiglione apudSauerländer, 1983, p. 268) ${ }^{53}$.

Neste fragmento do livro de Castiglione, o termo estilo é empregado para designar a expressão particular de um determinado artista. Neste sentido, a literatura italiana sobre arte plástica deste período retoma a palavra estilo num sentido próximo ao do termo latino maniera (maneira), termo empregado em Le vite de' piùeccellentipittori,

\footnotetext{
${ }^{52}$ De acordo com Sauerländer (1983, p.155), o termo estilo foi inicialmente utilizado na retórica e na poesia e posteriormente transferido para as artes irmãs, como a música, a pintura, a arquitetura e a escultura. Segundo o autor alemão, este lento processo de transferência do termo deixou marcas profundas na história da teoria artística na Itália do cinquecento, bem como na França do século XVII. Sobre a relevância do conceito de estilo para a história da arte, cf. SAUERLÄNDER, W. From stilus to Style: Reflections on the Fate of a Notion. Art History, Hamilton,v. 6, n.3, p. 253-270, September 1983.

${ }^{53}$ Traduzimos este fragmento direto original italiano, conforme foi reproduzido na nota 15 do referido texto de Sauerländer (1983, p.268).
} 
scultori e architettori (1550) de Giorgio Vasari (1511-1574) para designar o modo de produção característico de cada $\operatorname{artista}^{54}$.

Com efeito, a concepção de estilo como característica pessoal, ou seja, como a "maneira" particular de cada artista, permanecerá na literatura sobre arte do seicento italiano, porém podemos notar algumas inovações no uso do termo. Em Osservazione de Nicolò Pussino (1672), de Giovanni Pietro Bellori (1613-1696), a palavra stile já é utilizada com mais frequência do que no texto de Vasari, contudo, o seu uso ainda se dá num sentido idêntico ao do termo maniera. Bellori escreve: "o estilo é uma maneira particular e industriosa de pintar e desenhar nascido do gênio particular de cada um na

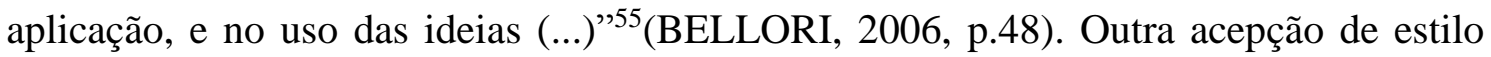
que se encontra no texto de Bellori é a qualificativa. É neste sentido que o autor de Vite de'Pittori, Scultori e Architetti Moderni traz o termo stile associado com uma diversidade de adjetivos, como magnífico, ottimo, perfetto, eroico, puro, bello e raro. Estilo, portanto, é algo como aprimoramento ou avaliação de uma obra ou de um $\operatorname{artista}^{56}$. Em seu Vite, Bellori afirma que Michelangelo foi sempre um modelo de "grande" estilo, e que em Deposition, Barocci teria atingido o perfetto stile ${ }^{57}$.

Entretanto, a despeito desta associação do estilo com a individualidade do artista e a originalidade da obra, em suas notas sobre Nicolò Pussino, Bellori aconselha os pintores de seu tempo a não subverter o decoro da história, o que sugere o emprego do termo estilo num sentido normativo ${ }^{58}$. Quando defende a importância dos grandes temas

\footnotetext{
54 Esta concepção de maneira aparece, por exemplo, em Le vite de' piùeccellentipittori, scultori $e$ architettori (1550) de Giorgio Vasari (1511-1574). Segundo Sohm (1999, p.104), ainda que o termo estilo já apareça no escrito de Vasari, encontramos uma supremacia do termo maniera. Enquanto o termo estilo aparece apenas 15 vezes no escrito, o termo maniera aparece 1300 vezes.

55 BELLORI, Giovanni Pietro. Observações de Nicolas Poussin sobre a pintura. In.: A pintura Textos essenciais. (VOL 10: Os gêneros pictóricos). Ed. 34. São Paulo: 2006 p. 48.

56 Acompanhamos aqui a leitura de Säuerlander que afirma: "Stile é uma noção de qualificação e avaliação (...) stile é sempre a qualidade de um artista individual ou de uma obra de arte singular"(SÄUERLANDER, 1983, p.258).

${ }^{57}$ Cf.SÄUERLANDER, 1983, p.258.

${ }^{58}$ Significativo para a consolidação e o desenvolvimento da estética clássica no Renascimento de modo geral, e na obra de Bellori de modo particular, foi a obra de Leon Battista Alberti (1404 - 1472).A partir de seus estudos sobre a obra de Vitrúvio, Alberti elaborou tratados como o De re aedificatoria e De statua, em que retoma os princípios centrais da arte clássica, a saber, a definição do belo como a harmonia entre todas as partes de um objeto. Também refletiu sobre o conceito grego demimese e a teoria das proporções na obra de arte, bem como as relações da arte com a ética e a ciência, repensando a função social do artista dentro do espírito da paideia grega. Para o historiador alemão J. Burckhardt, Alberti foi o protótipo do homem universal renascentista. Sobre a influência de Alberti no Renascimento, cf. BRANDÃO, Carlos Antônio Leite. Quid tum?: o combate da arte em Leon Battista Alberti. Belo Horizonte: Editora da Universidade Federal de Minas Gerais, 2000;
} 
em pintura, bem como a ideia de que o estilo deve se harmonizar à temática, isto é, deve ser grande ${ }^{59}$, o autor de Vite escreve:

[...] mas sendo grande a matéria em torno da qual vai concentrando seus esforços o pintor, a primeira advertência é que dos detalhes, com todas as suas forças, ele se afaste para não violar o decoro da história ${ }^{60}$, percorrendo com o impaciente pincel as coisas magníficas, e grandes, para deixar-se estar nas fúteis e vulgares (BELLORI, 2006, p.48)

Ao propor que a produção do grande estilo deve exigir do artista o respeito ao decoro da história, o que, neste contexto, significa se dedicar à criação do grande e se afastar do trabalho minucioso e do apreço pelo detalhe, Bellori reafirma a concepção normativa do estilo dos clássicos antigos, porém sem abrir mão da nova concepção individual e pessoal, o que parece denunciar um antagonismo inerente a esta moderna concepção de estilo, que ora é determinado por um decorum, ora é determinado pelo gênio individual. Este antagonismo que nasce com a modernidade irá perdurar até o seu ocaso.

De acordo com o Ästhetische Grundbegriffe, no século XVIII, a reivindicação da razão iluminista na produção discursiva inicia um processo de perda progressiva do prestígio da retórica. De uma disciplina relacionada ao conhecimento e à formação (Bildung) do homem, a retórica é rebaixada à condição de mera técnica inferior, o que resultará num gradativo abandono do paradigma retórico da concepção de estilo ${ }^{61}$ para se adotar cada vez mais a ideia de estilo como uma expressão individual e original. No Großes vollstandigesUniversallexikon ${ }^{62}$, enciclopédia alemã realizada por Johann Heirich Zedler entre os anos de 1731 e 1754, encontra-se o termo estilo não mais relacionado à normas ou prescrições estéticas que podem ser aplicadas a qualquer tempo e em todo lugar, mas como algo específico produzido por um indivíduo, região, ou país. Destarte, o termo estilo se afasta cada vez mais das ideias de norma e padronização para ser entendido como originalidade e, ainda que seja uma originalidade guiada por

\footnotetext{
${ }^{59}$ Cf. Lichtenstein, 2006, p. 46. LICHTENSTEIN, J (org.). A Pintura - vol.10: os gêneros pictóricos. Trad. Magnólia Costa. São Paulo: Ed. 34, 2006.

${ }^{60}$ Grifo nosso.

${ }^{61}$ Cf. BARK, K. FONTIUS, M. SCHLENSTEDT, D. (Orgs.). Ästhetische Grundbegriffe. Historisches Wörterbuch, Band 5.Stuttgart: Metzler, 2003, p. 651

62 Cf. ZEDLER, J.H. Großes vollstandiges Universallexikon, Bd.40. Leipzig: Bernhard Christoph Breitkopf, 1744, col.1471 - 1476.
} 
regras $^{63}$, estas já não constituem o fundamento do estilo que doravante passará a ser o próprio homem.

No contexto da discussão sobre o estilo do século XVIII, o Discours sur le Stylede Georges-Louis L. de Buffon é considerado um testemunho desta reformulação da noção de estilo na era do Iluminismo. Pronunciado na ocasião de sua recepção na Academia Francesa no ano de 1753, o Discurso de Buffon tende a valorizar as, ainda, incipientes noções da estética moderna, como as de gênio criador e de gosto, em detrimento das antigas noções da arte retórica, como as de harmonia, proporção e o belo matemático.

Dessa forma, no que diz respeito à concepção de estilo, quanto mais se exaltava a expressividade individual e original do artista ou escritor, menos sentido faziam as regras e o decoro da história até ao ponto de serem escamoteadas e transformadas em meros instrumentos a serviço do gênio criador. Buffon argumenta:

As regras, dizíeis-me ainda, não podem suprir o gênio; seeste faltar, elas serão inúteis. Escrever bem é, ao mesmo tempo, bempensar, bem sentir e bem reproduzir; é ter, ao mesmo tempo, o espírito,alma e gosto. $O$ estilo supõe a reunião e o exercício de todas asfaculdades intelectuais. As ideias, só por si, formam o fundo do estilo, a harmonia das palavras é tão-só o acessório e depende apenas dasensibilidade dos órgãos [...]. (BUFFON, 2011, p. 10-11)

Produzido a partir de uma operação que envolve todas as faculdades intelectuais do indivíduo, o estilo, para Buffon, consiste na capacidade do homem para dar forma aos seus pensamentos. Logo, o fundamento do estilo não está nas regras e nas normas clássicas da composição, como a harmonia, mas sim nas ideias e pensamentos.

Buffon acredita que o artista que segue com rigor os preceitos da retórica clássica não produzirá nada de significativo em arte, pois a submissão às normas significa o cerceamento do ímpeto criativo, logo, o fim de toda originalidade. O artista ou escritor cujo estilo se fundamenta em regras e normas está fadado à mera imitação, ou seja, a simples reprodução de formas canônicas desprovidas de ideias. Buffon afirma: "Ora a imitação nunca criou nada: por isso, a harmonia das palavras não constitui nem o fundo nem o tom do estilo e encontra-se, muitas vezes, em escritos desprovidos de ideias” (BUFFON, 2011, p. 11). Nesta acepção de estilo, as leis e regras

${ }^{63}$ Cf.SÄUERLANDER, 1983, p.256. 
são concebidas apenas como acessórios e jamais fundamentos. Neste sentido, se o princípio da harmonia nunca constituiu o fundo do estilo, tampouco determinou o seu tom. Este, segundo Buffon, resulta do seu ajustamento à natureza do assunto e deve ser sempre espontâneo, jamais forçado.

Então, cada forma estilística é compreendida como resultado do modo que o pensamento do artista é ordenado por ele mesmo segundo determinadas regras que, como visto, já não é o fundamento do estilo, mas apenas um instrumento para a sua realização. Buffon escreve:

O estilo é apenas a ordem e o movimento que se instaura nos seus pensamentos. Se eles forem encadeados de modo apropriado, se forem ajustados, o estilo torna-se robusto, nervoso e conciso; se eles se sucederem de forma lenta e se juntarem apenas por meio das palavras, por elegantes que sejam, o estilo será difuso, desligado e moroso (BUFFON, 2011, p.06).

O estilo, portanto, é o pensamento ordenado. Isto significa que toda variedade de formas estilísticas é determinada, em última instância, pelo tom, ou seja, pelo ajustamento do pensamento de acordo com o assunto, e não segundo regras formais prescritas.

No que tange o problema da variação estilística, na Enciclopédia se encontra esta mesma relação entre os vários estilos e o tom. Desta maneira, o "estilo poético" pode variar de acordo forma, originando diferentes gêneros (genres) ou estilos de poesia, como o "estilo lírico", o "estilo dramático", o "estilo bucólico", o "estilo do apólogo" e o "estilo épico". No décimo quinto tomo da Enciclopédia lê-se: "Por exemplo, as qualidades principais que convêm ao estilo épico são a força, a elegância, a harmonia e o colorido" (DIDEROT; D’ ALEMBERT, 1751-1765, p. 551). A prosa, por sua vez, assume a forma do estilo periódico, em que as proposições ou frases são ligadas umas às outras, ou o estilo fragmentado, em que todas as partes são independentes e sem ligação recíproca. Não obstante, tal como no estilo poético, cada gênero de obra prosaica demanda o estilo que lhe é próprio: "O estilo oratório, o estilo histórico e o estilo epistolar tem cada um suas regras, seu tom e suas leis particulares" (DIDEROT; D’ ALEMBERT, 1751-1765, p. 553).

Uma vez que se sobrepõe às normas e prescrições do decoro da história, a concepção moderna de estilo, conforme expressa por Buffon, assume como fundamento 
o pensamento ${ }^{64}$ e, por conseguinte, o próprio indivíduo. Tal concepção está expressa de modo peremptório na sentença mais conhecida do seu Discurso, aquela em que o autor identifica o estilo com o homem: "O estilo é o próprio homem” (Le style, c'est l'homme même $)^{65}$ (BUFFON, 2011, p.11). A sentença de Buffon representa o acabamento de uma concepção de estilo que começou a se delinear no pensamento moderno desde a sua fundação.

Não obstante, pode-se constatar nas últimas décadas do século XVIII uma radicalização desta concepção, como é o caso dos escritores do Sturm und Drang (Tempestade e ímpeto), movimento literário que eclodiu na Alemanha por volta de $1770^{66}$. Dentre os expoentes deste movimento, Karl Philip Moritz foi um dos primeiros a adotar e radicalizar esta moderna acepção do termo estilo. Em seu Vorlesungen über Stil (1793), o filósofo alemão se esquiva da concepção normativa da retórica para reafirmar a concepção fundada na ideia moderna de que o estilo está relacionado com a atividade criadora e original do artista genial, aquele que busca as regras de sua arte em si mesmo.

Neste sentido, o estilo belo não está submetido às leis matemáticas da harmonia e proporção, mas advém da força formadora do artista capaz de criar uma forma perfeita a partir do sentimento e da observação de objetos sensíveis e vulgares ${ }^{67}$. Em Signatur des Schönen und andere Schriften zur Begründung der Autonomieästhetik, Moritz escreve:

Uma vez que essa representação do Belo mais elevado tem que, necessariamente, fixar-se por meio de alguma coisa, a força formadora (...) elege algo que seja visível, audível ou palpável

\footnotetext{
${ }^{64}$ Podemos encontrar em Nietzsche esta acepção de estilo, por exemplo, quando afirma que melhorar o estilo é melhorar o pensamento. No entanto, é preciso levar em conta a distância entre a noção de pensamento em Nietzsche e Buffon. Cf. Nachlass/FP 1882 - 1884, 12[1], KSA 10.383.

65 Sobre a relevância das ideias de Buffon para uma concepção moderna de estilo, cf. BARK, K. FONTIUS, M. SCHLENSTEDT, D. (Orgs.). Ästhetische Grundbegriffe. Historisches Wörterbuch, Band 5. Stuttgart: Metzler, 2003, p. 651; SAUERLÄNDER, W. From stilus to Style: Reflections on the Fate of a Notion. Art History, Hamilton,v. 6, n.3, p. 253-270, September 1983, p. 256.

${ }^{66}$ A expressão Sturm und Drang foi retirado de uma peça homônima de F. M. Klinger, simbolizava a inquietude e a força expressiva de seus integrantes, jovens brilhantes como Hamann, Herder, Goethe, Lenz e Schiller. Segundo Werle (2000, p. 23), o objetivo do movimento era a emancipação das letras nacionais e seus temas básicos eram: a) a incompatibilidade entre o indivíduo e a sociedade, cuja conseqüência era uma dor do mundo (Weltschmerz); b) a ênfase no gênio criador e na subversão das regras artísticas; c) o acentuado individualismo nas artes e d) o sentimentalismo. Sobre este tema Cf. WERLE, M.A. Winckelmann, Lessing e Herder: estéticas do efeito? Trans/Form/Ação. São Paulo, n.23, p. 19-50, 2000.

67 Este pensamento exercerá uma forte influência sobre a concepção goethiana-schilleriana de estilo, como pretendemos mostrar no segundo capítulo.
} 
(...) para o qual ela possa transferir o brilho do Belo mais elevado em medida rejuvenescida (MORITZ, 2009, p. 42)

Com efeito, ao conceber o estilo como a impressão de si do gênio individual, o pensamento de Moritz fomentará na estética alemã do fim do século XVIII uma considerável valorização do culto ao gênio, bem como das noções de inovação e originalidade em arte. No entanto, paralelamente a esta concepção de estilo como criação original, Moritz também foi influenciado pela especulação fisionômica de Johann Caspar Lavater ${ }^{68}$, o que o levou a desenvolver uma concepção fisionômica de estilo $^{69}$. Conforme concepção, assim como há uma fisionomia do corpo, há também uma fisionomia do espírito ou da mente, para expressar o estilo. As consequências desta concepção fisionômica de estilo influenciarão mais tarde autores como Arthur Schopenhauer.

Em Parerga e paralipomena, Schopenhauer escreve: "O estilo é a fisionomia do espírito. É mais infalível que a do corpo" (SCHOPENHAUER, 2009, p. 527) ${ }^{70}$. Com isso, o filósofo alemão pretende mostrar que, ainda que a fisionomia do corpo possa enganar, ou seja, que um belo corpo seja desprovido de um grande espírito e vice-versa, é indiscutível que o bom estilo e a bela arte sejam outra coisa senão a produção de um espírito superior, assim como o mau estilo a de um espírito trivial. Neste sentido, afirma o filósofo, o estilo é também "a simples silhueta do pensamento" (SCHOPENHAUER, 2009 , p. 530) e, como tal ele deve trazer necessariamente a marca do pensamento que o precedeu.

Para Schopenhauer, o estilo de um determinado autor ou artista expressa o grau de força e autenticidade do seu pensamento, logo, o espírito superior, aquele que pensa por si, é capaz de produzir uma obra superior, enquanto o espírito vulgar, que só reproduz pensamentos alheios, está fadado à mediocridade. A capacidade de pensar por si de um espírito superior deriva de sua disposição para contemplar as Ideias $(\text { Idee })^{71}$,

\footnotetext{
${ }^{68}$ Johann Kaspar Lavater (1741 - 1801) foi um pastor, teólogo e poeta suíço entusiasta do magnetismo animal. É considerado o fundador da fisiognomonia no Ocidente, a arte de conhecer a personalidade das pessoas através dos traços fisionômicos.

${ }^{69}$ Cf. BARK, K. FONTIUS, M. SCHLENSTEDT, 2003, p. 652.

${ }^{70}$ Esta mesma definição de estilojá aparece naCrítica da filosofia kantiana de Schopenhauer (Cf. Schopenhauer, 2005, p.560).

${ }^{71} \mathrm{O}$ conceito schopenhaueriano de Ideia deriva de uma aproximação que o filósofo alemão intenta fazer entre as doutrinas de Platão e Kant. Schopenhauer escreve: "Por conseguinte, só a Ideia é a mais adequada objetidade possível da Vontade ou coisa-em-si; é a própria coisa-em-si, apenas sob a forma da representação: aí residindo o fundamento para a grande concordância entre Platão e Kant, embora, em sentido estrito e rigoroso, aquilo de que ambos falam não seja o mesmo" (SCHOPENHAUER, 2005, p.242). Para Schopenhauer, o mundo em sua totalidade é concebido como Vontade e Representação. As
} 
representações eternas e imutáveis da Vontade $(\text { Wille })^{72}$. Já a beleza de seu estilo consiste na sua capacidade de expressar com clareza e objetividade a Ideia apreendida na obra. Para Schopenhauer, a contemplação de uma Ideia, bem como a técnica necessária para expressá-la num estilo claro, simples e ingênuo, são atributos que constituem a essência do gênio ${ }^{73}$.

Quanto mais o ideal moderno de liberdade e originalidade da expressão individual ganhava força, mais a concepção de estilo se identificava com as noções de inovação e singularidade, contudo sem se desligar completamente do seu passado tradicional de regra, norma e prescrição, a moderna concepção de estilo assume um caráter antagônico, pois, se por um lado é determinado pela personalidade do indivíduo, por outro nunca abandonou o seu aspecto normativo e prescritivo remanescente da antiga retórica. Neste sentido, Säuerlander escreve:

Somente por ser estilizado, apenas por adaptar o original eo particular com certas regras pré-estabelecidas, qualquer obra de arte pode se tornar a portadora de uma mensagem social e um fato social total. Mesmo as formas mais extremas de originalidade só podem funcionar enquanto têm as normas e as convenções de estilo para defini-los. Assim, nós não vamos tão facilmente nos livrar da estrutura de dupla face do conceito moderno de estilo, com os seus princípios antitéticos de regra $e$ originalidade (SÄUERLANDER, 1983, p. 259).

\footnotetext{
representações são objetivações da Vontade, isto é, a Vontade que se torna objeto para um sujeito, o que pode ocorrer em diversos e específicos graus. Dentre essas representações estão as Ideias, o grau mais nítido e completo de objetivação da Vontade, uma vez que são a objetidade imediata da Vontade. No $\$ 32$ de $O$ Mundo como Vontade e Representação, Schopenhauer afirma: “Antes, a Ideia é para nós apenas a objetidade imediata e por isso adequada da coisa-em-si, esta sendo precisamente a Vontade, na medida em que ainda não se objetivou, não se tornou representação" (SCHOPENHAUER, 2005, p.241). A Ideia, portanto, é a única objetivação imediata e mais adequada da coisa-em-si, que é a Vontade (Cf. Schopenhauer, 2005, p.242). Ela se expõe em inúmeros fenômenos individuais, estes últimos se relacionam com a primeira como as cópias se relacionam com os modelos.

${ }^{72} \mathrm{Em}$ linhas gerais, o conceito de vontade (Wille) representa o núcleo da metafísica de Schopenhauer e é empregado pelo autor de $O$ Mundo como Vontade e Representação para designar o princípio ontológico fundador do mundo enquanto representação, logo é a única coisa que existe para além das representações. Ao propor tal princípio, a filosofia de Schopenhauer se afasta da concepção otimista da existênciaque emanava do racionalismo moderno, particularmente, o de Hegel. $\mathrm{O}$ ato volitivo, ao contrário do racional, não conduz ao aquietamento e ao conforto, mas à insaciabilidade e ao sofrimento eterno, o que gera um pessimismo radical cujo único conforto é a negação da vida através do ideal ascético. De acordo com a opção do tradutor da edição brasileira de $O$ Mundo como Vontade e Representação, utilizaremos o termo "Vontade" com o emprego do maiúsculo na letra inicial para designar o princípio ontológico schopenhaueriano, e "vontade" com o minúsculo na letra inicial para designarmos a vontade no sentido do querer humano.

${ }^{73}$ Nietzsche retoma esta ideia de Schopenhauer em sua Primeira Consideração Extemporânea, quando afirma que a simplicidade de estilo sempre foi uma característica do gênio, o único capaz de se expressar com naturalidade e ingenuidade (Cf. DS/Co. Ext. I $§ 10$, KSA 1.216).
} 
Desta perspectiva, por mais que a expressividade artística esteja relacionada à singularidade e originalidade da obra, só pode ser compreendida e comunicada caso se submeta a normas e princípios estéticos objetivos. Tomar o estilo como a expressão singular de um indivíduo, de um país ou de uma região, portanto, é apresentar apenas uma face deste conceito em relação ao sentido que assume na modernidade. Alguns passos deste percurso para examinar o momento mais significativo desta construção moderna da concepção de estilo, em que o estilo deixa de ser visto sob a expressão do indivíduo genial, conforme visto em Bellori e Buffon, para ser novamente concebido num sentido normativo e histórico, assim que é utilizado como instrumento de periodização da história da arte.

Schapiro entende que o estilo é compreendido como "uma manifestação da cultura como totalidade; é o signo visível de sua unidade. O estilo reflete ou projeta a 'forma interior' do pensamento e do sentimento coletivos"(SCHAPIRO, 1982, p. 36). Com efeito, o que interessa não é o estilo de um indivíduo específico ou de uma obra específica, mas as formas ou qualidades que são partilhadas por todos os artistas e artes de uma determinada cultura durante um determinado tempo. Dessa maneira ocorrem as expressões "homem clássico", "homem do renascimento", bem como "estilo grego clássico" e "estilo barroco".

Destarte, um crítico julga um determinado artista por "ter estilo" ou uma determinada arte por ser "desprovida de estilo", uma cultura também pode ser avaliada nesses termos. Neste sentido normativo, o estilo é utilizado como um critério de avaliação da cultura, uma vez que torna evidente tanto a unidade quanto a dispersão na forma do pensar, de sentir e de agir de seus integrantes. A grandeza ou a decadência de uma determinada cultura, portanto, varia de acordo com a força e disposição para instituir um estilo, ou melhor; dela "ter estilo" ou de "ser desprovida de estilo"74. Para Schapiro (1982, p. 36), é neste sentido que Winckelmann, ao avaliar o estilo da arte grega clássica, irá considerar o estilo como um fenômeno mais complexo do que uma mera convenção formal. Com efeito, ele é um produto consciente, o apogeu de uma determinada concepção e foi realizado através de uma rigorosa disciplina e do constante aperfeiçoamento deste povo. $\mathrm{O}$ estilo da arte grega clássica é entendido, por Winckelmann, em última análise, como a forma sensível da unidade do ideal grego

\footnotetext{
${ }^{74}$ Cf. Schapiro, 1982, p. 37.
} 
clássico; é a expressão artística e concreta do modo de pensar e de sentir, não de um indivíduo isolado, mas de uma cultura como totalidade.

De fato, no decurso das especulações históricas e estéticas de Winckelmann que esta concepção de estilo foi introduzida. Para Hoops (2005, p. 01), Winckelmann concebeu o estilo como uma unidade formalmente estruturada que expressa oêthose as formas de vida de uma determinada cultura. Em sua Geschichte der Kunst des Altertums, Winckelmann afirma que as fases de origem, crescimento e ocaso de uma determinada cultura ficam marcadas na produção artística de seu povo por intermédio do estilo. Nesta obra, o historiador alemão relaciona o desenvolvimento da cultura grega com quatro fases estilísticas da arte: o estilo "mais antigo", o "grande estilo", o "belo estilo" e o "estilo imitativo"75. Dessa forma, sempre que defende como possível o intento da história da arte em mostrar a origem, o progresso, as transformações e o ocaso da arte a partir dos diferentes estilos das nações, períodos e $\operatorname{artistas}^{76}$, o estilo, para Winckelmann, compreende-se como um instrumento hermenêutico com o qual o historiador da arte acessa e compreende o êthos de povos antigos ${ }^{77}$. Segundo Ritter e Gründer (1998, p. 155), ao propor tal concepção histórica de estilo, Winckelmann tornase o "pai da história da arte"78.

${ }^{75}$ Cf. WINCKELMANN, J.J. Essays on the philosophy and history of art. Vol. III. Trans. Curtis Bowman. New York: Continuum, 2005.

${ }^{76}$ Cf. WINCKELMANN, J.J. Essays on the philosophy and history of art. Vol. III. Trans. Curtis Bowman. New York: Continuum, 2005. Sobre a criação de uma nova concepção de estilo por Winckelmann, cf. BARK, K. FONTIUS, M. SCHLENSTEDT, 2003, p. 653; HOOPS, 2005, p. 01; RITTER; GRÜNDER, 1998, p. 155.

77 Para Säuerlander (1983, p. 260), Winckelmann é o reponsável pela "estetização" do historicismo iluminista de Voltaire e Montesquieu, bem como por tornar a tradicional concepção normativa de estilo numa concepção retórica.

${ }^{78}$ De fato, a partir da concepção histórica de estilo desenvolvida por Winckelmann foi decisiva para uma nova compreensão de história da arte que, desde então, passa a considerar a história dos estilos artísticos como uma ferramenta de pesquisa. Em Conceitos fundametais da história da arte. HeinrichWölfflin sustenta que a história da arte deve conceber o estilo "sobretudo como expressão, expressão do espírito de uma época, de uma nação, bem como expressão de um temperamento individual" (WÖLFFLIN, 1982, p.13). Neste registro também encontramos L'Art de reconnaitre les styles, de Émile Bayard, em que escreve: "Os estilos são a lembrança estética das épocas através dos vários cultos de beleza. $\mathrm{O}$ pensamento dos séculos dorme nestas pedras, nestes móveis, numa palavra, nestas coisas sobrevivem gerações como tantas testemunhas de sua moral e suas aspirações ideais" (BAYARD, 1913, p. 01). Meyer Schapiro (1982, p. 36) considera o estilo como um importante objeto de investigação, uma vez que possibilita situar e datar a origem das obras de arte, bem como elucidar as relações entre escolas artísticas distintas. Schapiro, considera que o estilo consiste num "sistema de formas" e que, por possuir uma qualidade e uma expressão significativas, é capaz revelar a personalidade de um artista e a concepção geral de um determinado grupo social. Assim, com Winckelmann, Schapiro considera o estilo como "um veículo de expressão no interior do grupo, que comunica e que fixa certos valores de sua vida religiosa, social e moral através das sugestões emotivas das formas" (SCHAPIRO, 1982, p. 36). Considerando a sucessão das obras no tempo e no espaço, o historiador da arte compara a variação estilística com os eventos históricos e com as mudanças em outras esferas da cultura. Nesta perspectiva, o estudo histórico dos estilos pode ajudar a elucidar os processos que subjazem a transformação e o desenvolvimento das formas. 
Não obstante, a despeito da importância desta nova concepção histórica de estilo para toda a história da arte vindoura, a ideia de tomar o estilo como um instrumento hermenêutico destinado à compreensão do êthosde povos antigos não é, para Winckelmann, a meta de sua reflexão. O objetivo de Winckelmann ultrapassa o âmbito estritamente especulativo na medida em que propõe utilizar o estilo, particularmente o da arte grega clássica, como um paradigma estético e ético para se pensar o seu próprio tempo. É nessa perspectiva que o historiador alemão pensará as obras de arte do período grego clássico para produzir uma teoria acerca da importância da imitação da arte grega, particularmente a escultura, na formação do bom gosto (Bildung des guten Geschmacks) do artista moderno.

Em suas Reflexões sobre a arte antiga, Winckelmann escreverá que a única maneira do homem se tornar tão grande e inimitável como os gregos é imitá-1o ${ }^{79}$. Em linhas gerais, Winckelmann acredita que os gregos expressaram em seu estilo artístico a "nobre simplicidade" e a "serena grandeza" de seu caráter ${ }^{80}$, logo imitar este estilo consiste em incorporar em si este caráter, ou seja, formar a alma de acordo com ele. Para Winckelmann, o que Rafael fez foi imitar os antigos, eis a sua grandeza. Em relação ao pintor italiano, escreve:

O verdadeiro gosto da Antiguidade o acompanharia (Rafael) constantemente, mesmo para imitar a natureza comum, e todas as observações que ele fizesse tornar-se-iam nele, por uma espécie de transformação química, aquilo que constituía o seu ser, a sua alma (WINCKELMANN, 1975, p. 49).

Com efeito, os gregos antigos são, para Winckelmann, o modelo paradigmático de formação do homem; e o estilo, como forma visível do ethos de um povo, é o princípio estético a partir do qual esta formação se torna comunicável e imitável ao homem moderno. Deste modo, assim que se relaciona pela primeira vez o estilo e ideia de formação, Winckelmann dará uma extensão ética e pedagógica a compreensão histórica de estilo influenciará decisivamente toda uma geração de autores que, doravante, pensarão o estilo no âmbito da discussão sobre a formação do homem.

Neste sentido, em Einige Wahrnehmungen über Form und Gestalt (1778), Herder aprofundará esta concepção ao relacionar o estilo com a ideia de formação da

\footnotetext{
${ }^{79}$ Cf. WINCKELMANN, 1975, p.39-40.

${ }^{80}$ Cf. WINCKELMANN, 1975, p.53. Uma análise mais aprofundada da relação entre estilo e formação no pensamento de Winckelmann será feita no nosso segundo capítulo.
} 
alma. Segundo Hoops (2005, p.01), Herder considera a arte visual ${ }^{81}$ como uma alegoria estável (beständige Allegorie), pois, para o filósofo alemão, “(...) ela forma a alma (Seele) através do corpo"(Herder apud HOOPS, 2005, p. 01). Assim, afirma Hoops, “(...) Sob a forma (Form) e o estilo (Stil), manifesta-se o sentido espiritual (geistige Sinn)" (HOOPS, 2005, p. 01) ${ }^{82}$. As considerações de Winckelmann e de Herder sobre a relação entre o estilo artístico e a formação do homem será o ponto de partida da reflexão estético-pedagógica do classicismo alemão de Goethe e Schiller.

Em seu ensaio Imitação simples da natureza, maneira, estilo, de 1789, Goethe continua a perspectiva normativa do estilo desenvolvida por Winckelmann. Neste ensaio, Goethe defende a "imitação simples da natureza"(Einfache Nachahmung der Natur) e a "maneira"(Manier) como etapas introdutórias e necessárias à atividade artística mais elevada que é o estilo (Stil): a essência ideal de coisas representada em formas visíveis e tangíveis ${ }^{83}$. Segundo Ritter e Gründer, "Numa época que está começando a descobrir o estilo como a expressão individual de personalidade, Goethe eleva o estilo 'ao mais autoconceito de valor (Wertbegriff) atemporal de uma estética objetivista"” (1998, p. 156). Como nível mais elevado da produção artística, o conceito goethiano de estilo se encontra em estreita relação com a sua noção de formação da bela alma (Schönseele), o que significa formar o homem por meio da arte, de modo particular, a grega clássica.

A concepção estético-moral de estilo desenvolvida por Goethe será retomada por Schiller. Em cartas enviadas ao amigo Körner, no ano de 1793, o autor afirma ser o estilo o princípio supremo das artes, o que significa a plena liberdade da obra de arte e a realização do belo. Ao contrário de Goethe, que é complacente com a "maneira", Schiller não aceitará tal procedimento em arte opondo-o de modo radical ao conceito de estilo. Não obstante, entenderá o estilo ideal como a realização dos princípios winckelmannianos de ingenuidade e simplicidade da arte clássica, doravante, atingirá o estilo ingênuo e simples como o ponto de partida para uma nova concepção de formação do homem através de uma educação estética (aesthetischerErziehung), uma educação da

\footnotetext{
${ }^{81}$ Segundo Hoops, Herder utiliza um mecanismo de diferenciação entre as artes plásticas segundo o qual, afirma: “A escultura é uma 'arte corpórea' - em oposição à pintura, que não é uma representação corpórea, mas é descrição, fantasia e representação, qualidades que se revelam através do olho (HOOPS, 2005, p.01).

${ }^{82}$ Sobre a noção de estilo em Herder, cf. BOTZ-BORNSTEIN, T. 'ART', Habitus, and style in Herder, Humboldt, Hamann, and Vossler: Hermeneutics and linguistics. Linguistic and Philosophical Investigations. New York, Volume 13, p. 121-139, 2014; HOOPS, 2005, p. 01.

${ }^{83}$ Cf. Goethe, 2008, p. 69.
} 
sensibilidade humana através da $\operatorname{arte}^{84}$. Deste modo, no que diz respeito ao pensamento estético da época de Goethe, não se pode separar o estilo do conceito de formação.

A proximidade entre os conceitos de estilo e formação também pode ser observada de uma perspectiva etimológica, haja vista que, tal como o termo alemão Stil, a palavra Bildung, em suas origens latinas, converge tanto para o vetor ético quanto para o estético ${ }^{85}$. No que tange o sentido estético, o Geschichtliche Grundbegriffe traz a afirmação de que, em sua origem, o termo Bildung significava Bild (imagem/figura), Abbild (imagem), Ebenbild (retrato/imagen), como também Nachbildung (cópia/imitação) e Nachahmung (imitação). Importante também serão os significados de Gestalt (forma) e Gestaltung (formação/realizaçao) e, neste sentido, encontra-se bem próximo de outro termo alemão Form (forma) e Formation ${ }^{86}$. No Deutsches Wörterbuch dos Irmãos Grimm, a palavra Bildung aparece com quatro significados latinos: (1) Imago; (2) forma; (3) cultus animi; (4) formatio, institutio.

Contudo, a palavra Bildung aos poucos se afasta deste sentido de forma para assumir cada vez mais o sentido religioso e pedagógico de imagem e modelo. Segundo Hell, Bildung

[...] é um termo tipicamente goethiano. Suas origens remontam à mística da Idade média, o verbo bilden logo se aplica à imagem de Cristo que se imprime na alma do cristão, mas é no curso do século XVIII que a ideia de Bildung determina essencialmente a evolução da pedagogia, que visa menos a inculcar conhecimentos do que a desenvolver dons inatos (HELL, 1974, p.38).

Originado na mística medieval, o termo alemão Bildung faz referência à imagem (Bild) de Deus que o homem carrega na sua alma, imagem segundo a qual ele foi criado e deve se formar. Nesta acepção está representada a ideia de Imago Dei que se encontra

\footnotetext{
${ }^{84}$ Analisaremos de modo mais aprofundado a relação entre estilo e formação no pensamento de Goethe e Schiller em nosso segundo capítulo.

${ }^{85}$ Segundo Bombassaro, "as raízes greco-latinas da Bildung convergem para três vetores responsáveis pela formação humana: o conhecimento, a ética e a estética" (BOMBASSARO, 2009, p. 202).

${ }^{86} \mathrm{Em}$ Verdade e Método, Gadamer faz um dedicado estudo etimológico acerca do termo alemão Bildung procurando termos equivalentes em outras línguas, como no latim (formatio), no inglês (form e formation) e alguns termos no alemão que competem com o termo Bildung, como Formierung e Formation. O filósofo alemão escreve: “(...) desde o aristotelismo da Renascença, forma (Form) vem sendo inteiramente desvinculada de seu significado técnico e interpretada de maneira puramente dinâmica e natural. Também o triunfo da palavra Bildung sobre a palavra Form não parece só acaso, pois no conceito de "formação" (Bildung) encontra-se a palavra 'imagem' (Bild). O conceito de forma retrocede para aquém da misteriosa duplicidade da palavra 'imagem', que abrange tanto o significado de 'cópia' (Nachbild) quanto o de 'modelo' (Vorbild)" (GADAMER, 2005, p. 46).
} 
nos místicos do medievo alemão, como Meister Eckart (1260 - 1328) e Jacob Böhme (1575 - 1624). Segundo Klafki (2007, p. 20) a partir do século XVIII a palavra Bildung receberá um tratamento filosófico uma vez associada a conceitos-chave da filosofia alemã deste período como os de liberdade, emancipação, autonomia, razão, autodeterminação, maioridade etc. Nesta sequência, Gadamer considera o pensamento da Bildung como o maior pensamento do século XVIII. O filósofo alemão escreve:

O conceito de formação [Bildung] [...] é, sem dúvida alguma, a ideia mais importante do século XVIII e é precisamente esse conceito que designa o elemento em que vivem as ciências do espírito do século XIX, mesmo que não saibam justificar isso epistemologicamente. [...] No conceito de formação percebe-se claramente quão profunda é a mudança espiritual que nos permite parecer contemporâneos do século de Goethe, e, em contrapartida, considerar a época barroca como um passado préhistórico. Conceitos e palavras decisivas, com as quais costumamos trabalhar, foram cunhadas naquele tempo [...] (GADAMER, 2005, p. 44).

Para Gadamer, o conceito de Bildung,um conceito capital no contexto do pensamento social e político da Alemanha dos séculos XVIII e XIX, no qual se expressa o anseio do alemão para a construção de uma unidade simbólica, uma primeira imagem da nação alemã, o que poderia ocorrer a partir da formação individual do homem. Não obstante, a formação do homem dependia de uma reforma da educação alemã ${ }^{87}$.

É neste contexto que Winckelmann, Goethe e Schiller constituirão, para o jovem Nietzsche, os primeiros alemães a empreenderem uma luta pela autêntica formação alemã. Em $O$ nascimento da tragédia, Nietzsche escreve:

Haveria alguma vez de esclarecer, sob os olhos de um juiz insubordinável, em que tempo e em que homens o espírito

\footnotetext{
${ }^{87}$ Esta conexão entre a formação do indivíduo e a construção da cultura (Kultur) será o ponto central do pensamento neo-humanistaalemão, cuja maior expressão é o pensamento de Wilhelm von Humboldt, pensador que exercerá forte influência sobre o pensamento nietzschiano. Segundo Gadamer, "com o fino senso que lhe é próprio, já percebe perfeitamente uma diferença de significado entre cultura e formação" (2005, p. 44). Tomando o conceito de cultura no sentido kantiano de um aperfeiçoamento de talentos, Humboldt estabelece uma diferença fundamental em relação ao conceito de formação. Humboldt escreve: "quando em nosso idioma dizemos 'formação', estamos nos referindo a algo mais elevado e mai íntimo (que cultura), ou seja, o modo de perceber que vem do conhecimento e do conhecimento do conjunto do empenho espiritual e moral, e que se expande harmoniosamente na sensibilidade e no caráter" (HUMBOLDT apud GADAMER, 2005, p.45-46). Sobre a noção de Bildung em Humboldt, cf. SORKIN, David. Wilhelm von Humboldt: the theory and practice of self-formation (Bildung), 1791-1810. In: Journal of the History of Ideas Jan. - March/1983.
} 
alemão lutou com mais vigor por aprender dos gregos; e se admitimos com confiança que esse elogio único deveria ser atribuído à nobilíssima luta de Goethe, Schiller e Winckelmann pela formação [Bildungskampfe], haveria em todo caso que acrescentar que, desde aquele tempo e depois das influências imediatas daquela luta, tornou-se cada vez mais débil, de maneira incompreensível, o esforço para chegar por uma mesma via à formação e aos gregos. (GT/NT $§ 20, K S A, 1.129)$

Enquanto configura o estilo como uma via de acesso aos ideais norteadores da cultura grega clássica, mas sobretudo como um princípio estético e ético com o qual o indivíduo moderno pode superar a barbárie do seu tempo, estes autores foram, segundo Nietzsche, os primeiros homens a se levantarem em meio à barbárie moderna e empreenderem uma verdadeira "luta pela formação", cuja ideia principal consiste em aprender com os gregos o verdadeiro sentido da formação do homem. Como herdeiro e continuador desta tradição, o jovem Nietzsche entenderá o estilo como um princípio estético fundamental para a tarefa da educação estética do homem.

Assim, quando se retorna à tradição da antiga retórica, pode-se observar que o termo estilo surge, primeiramente, para designar determinados instrumentos da agricultura, bem como o objeto utilizado pelos gregos para a escrita. Foi por metonímia que o termo passou a designar o modo de dizer ou escrever de um autor e, ainda no âmbito da antiga retórica, recebeu uma acepção normativa relativa a ideia do decorum. Ainda num sentido normativo, mas já apontou o caminho para uma concepção subjetiva, o Renascimento italiano aproximou a noção de estilo maniera, enquanto entendeu por estilo o modo como um autor realizou a sua produção artística. Neste contexto, viu-se que a palavra estilo extrapolou os domínios das artes retórica e poética para ser utilizada em outras artes, como as artes plásticas e a música. Foi apenas no século XVIII que o termo ganhou uma conotação completamente subjetiva, ou seja, deixou de ser entendido a partir da normatividade e objetividade do decorum para ser compreendido como uma expressão estética particular de um sujeito singular. Não obstante, paralelamente a esta concepção de estilo como originalidade e individualidade, viu-se surgir, como Winckelmann, outra concepção de estilo, concepção histórica a partir da qual o estilo passou a ser entendido como um instrumento hermenêutico 
utilizado pelo historiador da arte para compreender as épocas e povos passados. No entanto, como se evidenciou, as reflexões de Winckelmann não se limitaram à especulação histórica uma vez que deu ao seu conceito de estilo uma extensão ética. Com suas Reflexões sobre os gregos, Winckelmann propôs a utilização do estilo, particularmente o dos gregos clássicos, como instrumento para a formação do artista moderno. Quando relacionou pela primeira vez os conceitos de estilo e formação, Winckelmann abriu o caminho para que posteriormente Goethe e Schiller desenvolvessem uma teoria da formação cujo princípio consistiu na educação estética do homem a partir do estilo simples e ingênuo dos egos. A proposta a seguir será apresentar a análise da relação entre as noções de estilo e formação no âmbito do pensamento classicista de Winckelmann, Goethe e Schiller. 


\section{CAPÍTULO 2 \\ BÁRBAROS ILUSTRADOS \\ O estilo como antídoto contra a barbárie}

$\mathrm{Na}$ Primeira Consideração Extemporânea Nietzsche define o conceito de cultura nos seguintes termos: "Cultura (Kultur) é antes de tudo a unidade de estilo (Stil) artístico de todas as manifestações da vida de um povo" (DS/Co. Ext. I $\S 1$, KSA 1.159). Uma relação de reciprocidade é estabelecida entre as concepções de cultura e estilo e, neste sentido, pensar um implica necessariamente pensar o outro. Foi por constatar a ausência de unidade estilística na vida do povo alemão que o jovem filólogo pode afirmar, de modo peremptório, que "não existe nenhuma cultura original alemã" (DS/Co. Ext. I § 1, KSA 1.159).

Deste modo, o que o alemão moderno toma por cultura é exatamente o seu oposto, a barbárie (Barbarei), o que nos termos do filósofo quer dizer a "falta de estilo ou a confusão caótica de todos os estilos” (DS/Co. Ext. I § 1, KSA 1.159). Em suma, os alemães são bárbaros por serem incapazes de reduzir o caos de todos os estilos a uma unidade estilística comum, logo são impotentes para realizar uma autêntica cultura. Desprovido dos meios necessários para tal realização, o alemão deve buscar fora, numa cultura verdadeira, os elementos necessários para sua formação. Refere-se, neste caso, à concepção grega antiga.

Com efeito, ao tomar a cultura grega como um modelo de formação para o alemão moderno, Nietzsche passa a empreender, junto de Winckelmann, Goethe e Schiller, o que ele mesmo designou como uma "luta pela formação" (Bildungskampf) ${ }^{88}$ alemã. Enquanto segue a mesma via de seus predecessores, o jovem filósofo aponta a falta de educação estética como o motivo principal da barbárie alemã, mas também com os autores supracitados, irá propor a educação da sensibilidade através do estilo grego como o caminho para a superação da barbárie e a constituição de uma cultura como unidade de estilo artístico.

Em linhas gerais, neste capítulo, pretende-se reconstituir a relação entre o jovem Nietzsche e o pensamento classicista de Winckelmann, Goethe e Schiller a partir da relação entre os conceitos de estilo e formação. Mostrar-se-á, no presente estudo, que a relação estabelecida por Nietzsche entre a barbárie e a falta de educação estética do

${ }^{88}$ Cf. GT/NT § 20, KSA, 1.129. 
homem é uma herança do pensamento classicista alemão, como também o é, a proposta de recorrer à arte grega, ou melhor, aos princípios estéticos e éticos concretizados no estilo artístico dos gregos, como um meio de superação da barbárie.

Se cultura é unidade de estilo artístico de todas as manifestações da vida de um povo, então falar de conhecimento no contexto da Alemanha moderna é, da perspectiva do jovem Nietzsche, um contrassenso. Marcado pela ausência de unidade de estilo, bem como pela convivência caótica de todos os estilos, o alemão moderno está mais próximo da barbárie do que da sabedoria: "O alemão", afirma Nietzsche, "acumula em torno de si formas, cores, produtos e curiosidades de todos os tempos e de todos os lugares, ao produzir esse moderno colorido de feira que os doutos por sua vez vêm a considerar, e assim o formulam, o 'moderno em si' (Moderne an sich) "(DS/Co. Ext. I $\S 1$, KSA 1.159, trad. J.B.L.).

Nietzsche propõe uma inversão de perspectiva, pois aquilo que os doutos alemães consideram como sendo algo positivo, o "moderno em si", o filósofo considera como algo que foi derivado negativamente, já que o que este termo expressa, em última análise, a ausência de uma totalidade de conhecimento e de um estilo eminentemente alemão. Assim, a falta de uma unidade de estilo artístico que caracteriza a barbárie alemã é também o que faz desta nação uma modernidade nacional e, em plena oposição com a filosofia grega antiga.

Embora Nietzsche utilize frequentemente o termo bárbaro para caracterizar o homem alemão de seu tempo, o filósofo não o faz sem considerações prévias. Num apontamento póstumo redigido entre os anos de 1872 e 1873 escreve:

Os termos bárbaro e barbárie são expressões más e temerárias e assim, sem um preâmbulo, não me atrevo a utilizá-las: e se é verdade que os gregos diziam que o acento com que falavam os povos estrangeiros era como o coaxar e que, por isso, usavam o mesmo termo também para as rãs, então os bárbaros são, portanto, seres que coaxam - balbucios sem beleza e sem sentido. Falta de educação estética [aesthetischer Erziehung]. (Nachlass/FP 1872 - 1873, 19 [313], KSA 7.515). 
Com este preâmbulo, o filósofo alemão purifica o termo eximindo-o de seu sentido vulgar, como, por exemplo, da relação que se estabeleceu entre a expressão bárbara e a prática do canibalismo ou da pirataria. Obviamente que não se trata disso, haja vista que tais práticas já não correspondiam ao modo de vida da moderna Alemanha do século XIX. Ao associar a barbárie à falta de educação estética, o jovem Nietzsche retoma do classicismo alemão a oposição conceitual entre cultura e barbárie e, tal como seus predecessores, rebaterá essa com o antagonismo entre o "clássico" e o "moderno".

Em sua origem, o termo bárbaro foi derivado de "barbarófonos" (barbarophônon), palavra que aparece pela primeira vez no contexto dos poemas de Homero, mais especificamente no canto II da Ilíada. Num primeiro momento, a palavra foi utilizada para caracterizar os cários, habitantes da região de Cária localizada na Ásia menor. Estes homens eram considerados "barbarófonos" porque tartamudeavam de maneira confusa e incompreensível; falavam em borborismos e, por isso, foram designados bárbaros $^{89}$. Porém, mais tarde, o termo bárbaro ganhará uma tonalidade não apenas descritiva, mas pejorativa e, sobretudo, etnocêntrica, passando a ser utilizado para designar não mais exclusivamente os cários, mas todos os que não pertencem à raça ou à família grega ${ }^{90}$, enfim, os não-gregos. Diante da pureza e da beleza da língua grega, os idiomas estrangeiros, como afirma Nietzsche, soavam como um coaxar desprovido de beleza e sentido. Educado numa tal língua, o grego se sentia como o homem do discurso belo e racional, quando se sobrepunha aos áglôssoi (os sem-língua) e aos bárbaroi (os coaxantes) ${ }^{91}$. Posteriormente, o termo ganhará uma nova acepção na

\footnotetext{
${ }^{89}$ Ao definir os bárbaros como seres que coaxam (Cf. Nachlass/FP 1872 - 1873, 19 [313], KSA 7.515) Nietzsche se apóia numa interpretação filológica que constata a origem do termo bárbaro no procedimento grego de substantivação de uma onomatopéia. Sobre esta hipótese, Mattéi argumenta: "Se os filólogos hesitam a respeito da etimologia exata do termo barbaros,talvez uma onomatopéia proveniente de bambaino, 'bater os dentes', 'tremer de medo' (cf. o latim balbutio), não há dúvida de que a palavra soa mal em grego, com a repetição da primeira sílaba (bar-bar) e a rugosidade das duas consoantes $b$ e $r$ que retiram por duas vezes a liquidez da vogal. Falar em bárbaro significa falar em borborismos, o que não é a melhor maneira de se fazer entender" (MATTÉI, 2001, p. 77). Sobre a concepção de barbárie, cf. MATTÉI, J.F. A barbárie interior: ensaio sobre o i-mundo moderno. Trad. Isabel Maria Loureiro. São Paulo: Editora UNESP, 2002.

${ }^{90}$ Em Platão, o termo bárbaro já assumeuma perspectivaetnocêntrica na medida em que visa a demarcar a alteridade étnica dos povos estrangeiros em relação aos gregos, o que pode ser observado no seguinte argumento de Sócrates: "Vê então se o que vou dizer é também apropositado. Afirmo que a raça helênica é da mesma família e origem, e a dos bárbaros é de família estrangeira e alheia (...) Por conseguinte, diremos que, quando os Gregos combatem com os bárbaros e os bárbaros com os Gregos, estão em guerra, e que são inimigos por natureza, e que esta inimizade se deve chamar guerra" (Rep. V, 470c).

${ }^{91}$ Não obstante, a constituição deste discurso belo não foi casual, mas sim o resultado de um longo e meticuloso trabalho sobre a língua, empreendimento que culminou na arte da retórica Nos extratos do curso sobre a história da eloquência grega, Nietzsche escreve: "A eloquência foi cultivada pelos gregos com um labor e uma constância sem equivalente em nenhum outro domínio; dedicam-lhe uma energia
} 
tradição retórica latina que designará como barbarismo determinados vícios de linguagem ${ }^{92}$.

Porém, se por um lado as concepções nietzschianas de bárbaro e barbárie se aproximam da acepção antiga do termo, por outro ela se distancia na medida em que o objeto de sua crítica não é o homem antigo, mas moderno. Destarte, tais noções não podem ser reduzidas à categoria antropológica da alteridade étnica, o que se mostra evidente na medida em que o homem a quem o filósofo se refere como bárbaro é o alemão de seu tempo, seu patrício. É na esteira do classicismo alemão de Winckelmann, Goethe e Schiller que Nietzsche procura compreender o bárbaro e a barbárie como fenômenos tipicamente modernos. Por esta tradição, o jovem Nietzsche associará tais fenômenos ao tipo de formação que predomina na Alemanha moderna, uma estrutura que prioriza a ilustração (Aufklärung $)^{93}$ do intelecto em detrimento da educação da sensibilidade. Também com estes autores, Nietzsche pensará um novo conceito formador do homem alemão, que tem na educação estética do indivíduo o seu princípio fundamental.

Para Nietzsche, em suas incursões pelo mundo grego antigo, Winckelmann não teria como objetivo principal a especulação histórica acerca do objeto artístico, mas sim fazer uma crítica contundente à formação (Bildung), especialmente à alemã ${ }^{94}$. Ao afirmar que a imitação das obras de arte clássicas é o único caminho para se tornar grandes e inimitáveis como os gregos, o historiador alemão pensará o conceito de estilo um estreito relacionamento com o de formação, pois, para Winckelmann, imitar o estilo dos clássicos significa incorporar a nobre simplicidade e a grandeza serena de seu caráter.

No que diz respeito à interpretação moderna da cultura grega antiga, a reflexão de Winckelmann sobre a arte grega representa um ponto de virada na Alemanha e, de

cujo símbolo pode ser a educação que Demóstenes se impôs a si mesmo; a devoção à oratória é o elemento mais tenaz da cultura grega, e persiste através de todo o declínio desta (...) Ninguém deve pensar que uma tal arte caiu do céu; os Gregos nisso trabalharam mais do que qualquer outro povo e mais que qualquer outra coisa (...)" (extratos do curso sobre a história da eloquência grega, KGW II 4).

${ }^{92}$ Esta acepção pode ser constatada no seguinte fragmento de Donato: "O barbarismo é uma parte da oração que é viciosa na fala comum; nos poemas é um metaplasmo, e, do mesmo modo, barbarismo, em nossa língua, diz-se barbarolexis no estrangeiro, como se alguém disser mastruga, cateia, magalia. O barbarismo se faz de dois modos, falado e escrito, que se subdividem em quatro espécies: adição, supressão, alteração de letra, sílaba, tempo, tom ou aspiração" (Donato, Ars, GL IV, 367). (Barbarismus est una pars orationis uitiosa in communi sermone; in poemate metaplasmus, itemque in nostra loquella barbarismus, in peregrina barbarolexis dicitur, ut siquis dicat mastruga cateia magalia. Barbarismus fit duobus modis, pronuntiatione et scripto. His bipertitis quattuor species subponuntur: adiectio, detractio, inmutatio, transmutatio litterae, syllabae, temporis, toni, adspirationis (Donato, Ars, GL IV, 367).

${ }^{93}$ Sobre o conceito de Aufkärung, cf, nota 02.

${ }^{94} \mathrm{Cf} . \mathrm{GT} / \mathrm{NT} \S 20, \mathrm{KSA}, 1.129$. 
certo modo, em toda Europa do século XVIII. O modo original e rigoroso com que se tratou a cultura grega levou alguns autores a afirmar que, com Winckelmann, a Grécia deixa de ser uma categoria genérica para se tornar um objeto de reflexão muito específico $^{95}$. Em meio ao amplo debate moderno acerca do classicismo, o autor de Reflexões sobre a arte antiga fundará aquilo que se chamou de uma verdadeira "ciência do clássico" fixando as bases do novo classicismo europeu ${ }^{96}$.

Obras como Gedanken über die Nachahmung der griechischen Werke in der Malerei und Bildhauerkunst (1755) e Geschichte der Kunst des Alterthums (1764), inauguram, na modernidade, uma nova compreensão acerca dos gregos na medida em que visa a assinalar, com precisão, que o chamado "período clássico" não era, como se pensava até então, um longo período que compreenderia tanto a Grécia de Péricles quanto a Roma de Adriano. Tratava-se, sobretudo, de um momento histórico muito preciso localizado entre o final do século VI a. C. e o século V a. C., período marcado pelo surgimento de um corpo de obras, estilos e artistas que, para Winckelmann, consistia na mais alta conquista da arte em todos os tempos e, por isso mesmo, merecedor do qualificativo "clássico" 97.

Em Reflexões sobre a imitação das obras gregas na pintura e na escultura, Winckelmann descreverá esta arte grega clássica a partir de características mais fundamentais: a "nobre simplicidade" e a "grandeza serena". Nesta famosa passagem, que foi amplamente difundida por ter sido citada no Laocoonte (1766) de Lessing, Winckelmann apresenta as respectivas características estéticas como a expressão idealizada daquilo que, para os gregos, seria uma grande alma:

[...] o caráter geral, que antes de tudo distingue as obras gregas, é uma nobre simplicidade e uma grandeza serena tanto na atitude como na expressão. Assim como as profundezas do mar permanecem sempre calmas, por mais furiosa que esteja a

\footnotetext{
95 Cf. MAS, 2008, p. 09.

${ }^{96}$ Cf. Borhein, 1975, p. 13.

97 No que tange a sua etimologia, o termo "clássico", em alemão Klassische, deriva do termo latino classicus, modo como os latinos designavam a trombeta utilizada para convocar o povo para as assembléias na Grécia antiga dos séculos V-IV a.C. Não obstante, a conotação do termo sofre transformações no decorrer da história. Neste sentido, no Dicionário Oxford de Literatura Clássica afirma-se que, no latim tardio, o adjetivo classicus passou a designar aquilo que é "excelente em sua classe"; denotava ainda a procedência social do cidadão: classe alta. É neste sentido que o gramático romano Aulo Gélio (séc. II) contrapunha o scriptor classicus, escritor de primeira classe, ao sermoproletarius, linguagem chula empregada pelas classes baixas. Na língua alemã, o termo clássico passa a ser usual somente a partir do século XVIII sendo utilizado para designar os escritores e artistas antigos, os gregos e romanos, considerados como sendo os clássicos por excelência.Cf. HARVEY, P. Dicionário Oxford de Literatura Clássica. Rio de Janeiro: Jorge Zahar Editor, 1987.
} 
superfície, da mesma forma a expressão nas figuras dos gregos mostra, mesmo nas maiores paixões, uma alma magnânima e ponderada" (WINCKELMANN, 1975, p. 53).

Surge, com esta observação acerca do ideal grego de nobre simplicidade e de grandeza serena, uma visão da Grécia clássica como uma cultura eminentemente apolínea, ou seja, regida pelos princípios estéticos da harmonia e da bela aparência, eis o porquê de Winckelmann, em suas investigações, privilegiar as artes plásticas, de modo particular a escultura. Não obstante, é preciso ter em vista que "nobre simplicidade" e "serena grandeza" não são ideais propriamente estéticos, mas, sobretudo, éticos.

Gerd Bornhein (1975, p. 13) explica que a ideia de "nobre simplicidade" e "grandeza serena" não é uma ideia criada por Winckelmann, mas apropriada por ele de uma tradição que remonta ao pré-socrático Xenófanes ${ }^{98}$. Em linhas gerais, é uma tendência básica e constante do humanismo ocidental acreditar que o divino, o digno, o grande, o nobre e o perfeito estão necessariamente associados ao simples e ao calmo, ao imóvel e ao repouso. A contrapartida disso é a consideração de que o movimento é sintoma da ausência de perfeição, de insuficiência, debilidade e carência de realidade. No âmbito da tradição humanista ocidental, a sancta simplicitas (santa simplicidade) na Renascença italiana, as ideias de simplicité naturelle (simplicidade natural) e de noble simplicité (nobre simplicidade) nos clássicos franceses, a accurate simplicity of the ancients de Shaftesbury e a noção de schoene Seele (bela alma) no classicismo alemão seriam algumas versões desse antigo ideal humanista ${ }^{99}$. A originalidade de Winckelmann não estaria, portanto, na ideia, mas no modo de apreendê-la e incorporála no contexto do homem moderno.

É na imitação das obras de arte gregas, e não na imitação da natureza ${ }^{100}$, que Winckelmann vislumbra a possibilidade do homem moderno apreender o ideal grego.

\footnotetext{
${ }^{98}$ Bornhein identifica a primeira expressão deste ideal que associa o princípio de grandeza e nobreza ao de simplicidade, serenidade, enfim, estaticidade, encontra-se em Xenófanes, por exemplo, no fragmento em que diz que "nem é próprio de Deus mover-se". Cf. Bornhein, 1975, p. 15.

${ }^{99}$ Cf. Bornhein, 1975, p. 15.

${ }^{100}$ A concepção de que a imitação da natureza é o princípio da produção artística era uma ideia corrente no século XVIII, difundida, sobretudo, pela forte influência do estilo barroco. Cabe aqui mencionarmos que, cerca de dez anos antes de Winckelmann concluir suas Reflexões, foi publicado na França o tratado Les beaux-arts réduits à un même príncipe(1746), do abade Charles Batteux (1713-1780). Nesta obra,Batteux defende a imitação da natureza como o princípio supremo de toda produção artística. O autor escreve: "Qual é a função das artes? É a de transpor os traços que estão na natureza e apresentá-los em objetos que não são naturais (...) Donde concluo que as artes, naquilo que é propriamente arte, são apenas imitações, semelhanças que não são a natureza, mas que parecem sê-lo; e que, assim, a matéria das
} 
Em suas Reflexões, afirma que "o único meio de nos tornarmos grandes e, se possível, inimitáveis, é imitar os antigos (...)” (WINCKELMANN, 1975, p. 39-40). A exortação aparentemente paradoxal, que incita o artista moderno a imitar os antigos para se tornar tão inimitável como eles, não pode ser entendida como uma defesa da mera cópia como princípio da produção artística. Neste sentido, o conceito de imitação, em Winckelmann, indica aquilo que deve ser imitado é algo transcendental à obra, enfim, sua forma ideal; o eidos no sentido platônico. O que se objetiva com o procedimento da imitação da obra de arte dos gregos, em última análise, não é a própria obra imitada, a cópia, mas sim a apreensão do modo como os gregos, através da imitação da natureza real, tornou-a ideal. Winckelmann escreve:

\begin{abstract}
A imitação do belo na natureza diz respeito a um objeto único, ou reúne as observações sugeridas por diversos objetos e realiza um todo único. O primeiro procedimento significa fazer uma cópia parecida, um retrato; é o caminho que leva às formas e figuras dos holandeses. O segundo caminho que leva ao belo universal e às imagens ideais desse belo; foi o que os gregos trilharam. (WINCKELMANN, 1975, p. 47).
\end{abstract}

Há, portanto, duas vias possíveis para a produção artística: o primeiro resulta da apreensão imediata dos objetos naturais, como fizeram os pintores holandeses; o segundo da apreensão mediata da natureza, uma vez que se ocupa do objeto natural já idealizado pelo artista, procedimento tipicamente grego. Desse modo, o estilo grego não resultou de uma mera cópia da natureza, por mais exuberante que esta se apresentasse ao homem grego. Resultou do aperfeiçoamento da natureza com o objetivo de torná-la mais perfeita e ideal, ao dignificá-la.

Eis o sentido do ataque de Winckelmann à Bernini ${ }^{101}$ e ao estilo barroco, bem como o motivo que levou o autor das Reflexões a considerar o estilo dos gregos antigos como radicalmente oposto a este estilo. Em linhas gerais, Bernini procurava incentivar

belas-artes não é o verdadeiro, mas somente o verossímil” (BATTEUX, 2009, p. 27). Para Winckelmann, a imitação da natureza não é o fim da arte e tampouco o método adequado para o aprendizado artístico. Em suas Reflexões, Winckelmann escreve: "Mesmo se a imitação da natureza pudesse dar tudo ao artista, este não lhe deveria a exatidão do contorno que somente os gregos podem ensinar" (WINCKELMANN, 1975, p. 49).

${ }^{101}$ Gian Lorenzo Bernini (1598 - 1680) foi um eminente artista do barroco italiano que atuou, sobretudo, na cidade de Roma. Foi pintor, desenhista, cenógrafo, porém distinguiu-se como escultor e arquiteto. Produziu uma quantidade significativa de obras de arte sendo que parte delas ainda se encontra até os dias atuais em Roma e no Vaticano. As Reflexões de Winckelmann constitui um manifesto contra o estilo barroco e, de maneira particular, contra a obra e as concepções estéticas e pedagógicas de Bernini, concepções bastante difundidas na Alemanha no final do século XVIII. Sobre a crítica de Winckelmann à Bernini e ao estilo barroco, cf. Bornhein, 1975, p. 17. 
os jovens artistas a estudar preferencialmente a natureza no que ela mostra de mais belo, ao imitá-la. Tal modo de proceder, segundo Winckelmann, seria o caminho mais longo e menos seguro para chegar ao conhecimento do belo perfeito, a verdadeira meta de todo artista. Um caminho mais rápido e eficaz seria o da imitação das obras de arte dos gregos clássicos.

Obras como o Antinous Admirandos e o Apolo do Vaticanodemonstram, segundo Winckelmann, que os gregos já haviam superado a simples imitação da beleza natural e atingido a beleza ideal, por isso a imitação dessas obras pode oferecer ao jovem artista um caminho mais curto e mais seguro: "Creio que a imitação dessas obras permite mais rapidamente o aprendizado, pois o artista encontra, numa, a soma do que se encontra disperso em toda a natureza e, na outra, o ponto a que pode elevar-se a si mesma a mais bela natureza, com coragem e sabedoria” (WINCKELMANN, 1975, p. 48). Contudo, a teoria winckelmanniana da imitação não se aplica à arte grega como um todo, mas sim à produção artística de um período bem delimitado.

Em A história da arte, Winckelmann (2005, p. 116-117) considera como o apogeu da arte grega o período que vai do início do século $\mathrm{V}$ a. C. ao fim do século IV a. C, período que ficou conhecido como clássico. Este período tem início na transição do "estilo mais antigo", ainda pouco definido e marcado pela influência de outras culturas, como a egípcia, para o "grande estilo", representado na obra de artistas como Fídias $^{102}$ e Policleto ${ }^{103}$. Não obstante, esta época se prolongará até o aparecimento do que Winckelmann designou por "belo estilo", consumado na obra de artistas como Praxiteles ${ }^{104}$ e Lísipo ${ }^{105}$. Sobre esta fase, Winckelmann escreve:

\footnotetext{
${ }^{102}$ Fídias (480 a. C. - 430 a.C.) foi um célebre escultor da Grécia Antiga e fundador do classicismo escultórico, período também designado como alto classicismo. A ele costumam-se atribuir duas das mais conhecidas estátuas da Antiguidade, a Atena Partenos e o Zeus Olímpico. Durante o governo de Péricles, Fídias foi encarregado de supervisionarum amplo programa construtivo em Atenas cujo objetivo consistia na reedificação da Acrópole, devastada pelos persas em 480 a.C.

${ }^{103}$ Policleto $(460$ a. C. $-420 / 410$ a.C.) foi, junto com Fídias, um dos fundadores do classicismo escultórico. Pelos seus esforços teóricos no campo da arte - de modo particular o seu Cânone, tratado onde estipulou as regras da sua arte -, mas também pela grandeza de seu talento artístico - consumado em seu Doríforo, obra em que aplicou as regras de seu tratado e que por muito tempo foi considerada como o ideal da beleza masculina -, Policleto ficou conhecido como o "Pai da Teoria da Arte" do Ocidente.

${ }^{104}$ Praxiteles (395 a.C. -330 a.C.) foi um escultor da Grécia clássica. Várias obras de sua autoria, descritas na antiguidade, são conhecidas através de cópias romanas. Sua obra mais importante é a Afrodite de Cnido, vendida à cidade de Cnido depois de ter sido rejeitada em Kos, que preferiu uma versão mais pudica da deusa.

${ }^{105}$ Lísipo (390 a. C. - ?) foi o último dos grandes escultores da época clássica grega. Com Praxiteles, conduziu a evolução do alto classicismo para o helenismo, também denominado de classicismo tardio ou baixo classicismo.
} 
O estilo mais antigo durou até Fidias; através dele e dos artistas de seu tempo a arte atingiu a sua grandeza. Este estilo pode ser chamado de grande e sublime. Desde o tempo de Praxíteles ao de Lísipo e Apelles, a arte adquiriu mais graça e agradabilidade; este estilo deve ser nomeado o belo. (WINCKELMANN, 2005, p. 116-117).

Segundo Winckelmann, os grandes mestres do grande estilo procuravam a beleza ideal na perfeita harmonia e proporção ${ }^{106}$ entre todas as partes da obra, bem como no destaque da expressão da figura representada ${ }^{107}$. Por isso, é característico do grande estilo o traço impessoal, equilibrado e austero, pois o que se busca é representar a magnitude de um caráter divino e a aretê ideal. Para tanto, procura-se excluir da representação artística o sentimento individual e as violentas paixões. Winckelmann escreve:

Agora, se o princípio fundamental do grande estilo era, como parece, representar o semblante e atitude dos deuses e heróis como livres de emoção e não agitados por perturbação interior, num equilíbrio de sentimento e com serenidade; estado de espírito constante;vemos então por que uma certa graça foi desejada; mesmo que ainda não tenha sido feita nenhuma tentativa de apresentá-la (WINCKELMANN, 2005, p. 135).

Composto de leis simples e severas ${ }^{108}$, o grande estilo conferia à obra de arte grega o caráter ideal e divino almejado pelo artista, porém desprovido do elemento da graça $^{109}$.

É no início de Umensaiosobrea graça na obra de arte que Winckelmann define este conceito nos seguintes termos: "Graça é a harmonia do agente e da ação. Esta é

\footnotetext{
${ }^{106}$ De acordo com Steiner (2001, p. 39), a relação entre proporção e beleza parece ter sido um dos temas fundamentais do Cânone de Policleto, obra perdida de cujo conteúdo só podemos ter uma vaga compreensão através dos seus comentadores. Sobre a noção de beleza no Cânone, no De placitis Hippocratis et Platonis de Galeano lê-se:"não reside na simetria dos elementos do corpo, mas na adequada proporção entre as partes, como, por exemplo, de um dedo para outro dedo, dos dedos em conjunto para as mãos e o pulso, destes para o antebraço, dali para o braço, e de tudo para com tudo, assim como está escrito no Cânone de Policleto. Tendo nos ensinado neste tratado todas as simetrias do corpo, Policleto ratificou o texto com uma obra, tendo feito uma estátua de um homem de acordo com os postulados de seu tratado, e chamando a estátua, assim como o tratado, de Cânone. Desde então todos os filósofos e doutores aceitam que a beleza reside na devida proporção das partes do corpo" (GALEANO apud STEINER, 2001, p. 39-40).Cf. STEINER, Deborah. Images in mind: Statues in Archaic and Classical Greek Literature and Thought. Princeton: Princiton University Press, 2001.

${ }^{107}$ Cf. Winckelmann, 2005, p. 134.

${ }^{108} \mathrm{O}$ estilo a que Winckelmann se refere como "grande" também é designado pelos historiadores da arte como "estilo severo".

${ }^{109}$ Cf. Winckelmann, 2005, p. 134.
} 
uma ideia geral: para o que razoavelmente agrada nas coisas e ações denomina-se gracioso" (WINCKELMANN, 1765, p. 273). O elemento da graça foi introduzido na arte escultórica grega somente por um conjunto de artistas que sucederam os mestres do grande estilo. Enquanto torna mais flexíveis as regras do grande estilo e mais graciosa a expressão da figura representada, os novos artistas fundaram um estilo novo: o belo estilo. Para Winckelmann, comparar o grande estilo com o belo estilo é como comparar o homem da idade heroica, o herói homérico, com o homem ateniense cultivado no florescimento da república ${ }^{110}$

A graça, portanto, é a "peculiaridade distintiva" do belo estilo ${ }^{111}$ e é conseguida na medida em que o novo artista torna mais próximo da natureza as belezas sublimes e ideais de seus grandes mestres, o que ocasionou uma variedade maior nas formas no âmbito da produção artística grega ${ }^{112}$. Não obstante, afirma Winckelmann, "A variedade e maior diversidade de expressão no belo estilo não impede a sua harmonia e grandeza"(WINCKELMANN, 2005, p. 138). Nas representações do belo estilo, como no grande estilo, a alma ainda se manifesta de forma equilibrada e serena e está desprovida de ímpeto e violência. Winckelmann escreve: "Na representação do sofrimento, como no Laocoonte, a maior dor é ocultada; e a alegria flutua, como uma brisa suave que quase não mexe as folhas, sobre as faces de uma Leucotéia no Capitólio e de uma bacante nas moedas da ilha de Naxos" (WINCKELMANN, 2005, p. 138). Nas Reflexões, o Laocoonteé descrito como a obra de arte perfeita ${ }^{113}$ : a manifestação sensível do ideal estético e ético da Grécia clássica.

\footnotetext{
${ }^{110}$ Cf. Winckelmann, 2005, p. 134.

${ }^{111}$ Cf. Winckelmann, 2005, p. 134.

${ }^{112}$ A beleza grave e o caráter severo do grande estilo, segundo Winckelmann, reproduziam o caráter de seu tempo. O historiador alemão escreve: "Com tais ideias graves de beleza, a arte começou a ser grande, como os estados bem ordenados que prosperam com leis severas; e as figuras eram simples, como os modos e os homens da época". (WINCKELMANN, 2005, p. 135). Contudo, os novos artistas, diferente dos novos legisladores, não seguiram os antigos mestres da arte em suas regras e, introduzindo o elemento da graça na obra de arte, criaram um novo estilo: "Os sucessores imediatos dos grandes legisladores na arte, contudo, não procederam como Sólon o fez com as leis de Draco, eles não partiram de suas regras; mas como as leis mais rígidas tornaram-se mais usuais e aceitáveis através de uma interpretação temperada deles, então estes últimos procuraram trazer mais perto da natureza as belezas sublimes que, nas estátuas de seus grandes mestres, eram como ideias abstratas da natureza, e as formas modeladas sobre um sistema; e desta forma eles atingiram uma maior variedade. Este é o sentido em que devemos entender a graça introduzida pelos mestres do belo estilo em suas obras" (WINCKELMANN, 2005, p. 135).

${ }^{113}$ Para Winckelmann, a magnanimidade da alma grega se encontra expressa na fisionomia de Laocoonte. Nesta obra, afirma o historiador alemão, "A dor do corpo e a grandeza da alma estão repartidas com igual vigor em toda a estrutura da estátua e por assim dizer se equilibram. Laocoonte sofre como o Filoctetes de Sófocles. Seus sofrimentos nos penetram até o fundo do coração, mas desejaríamos poder suportar o sofrimento com essa grande alma" (WINCKELMANN, 1975, p. 53). OLaocoonte, escreve Winckelmann
} 
Dessa maneira, o procedimento da imitação das obras de arte gregas extrapola o sentido meramente técnico relacionado à produção artística na medida em que vislumbra, por meio do contato com a beleza ideal dos gregos, a formação do bom gosto (Bildung des guten Geschmacks) do homem moderno ${ }^{114}$. Com o estilo grande e belo, os gregos do período clássico expressaram não apenas um princípio estético, mas um caráter ideal, a nobre simplicidade e a grandeza serena que aproxima o homem natural dos deuses e heróis. Imitá-los, portanto, significa incorporar esta beleza e este caráter ideal para tornar-se tão inimitável quanto seus idealizadores. Ao tomar a Grécia antiga como um modelo de cultura a ser imitado pelos modernos, Winckelmann promove uma aproximação entre os domínios da ética e da estética, o que, no âmbito de uma época caracterizada pela ilustração (Aufklärung) era pouco usual, mas que entre os gregos era comum.

É importante ter em vista, quando se pensa a cultura grega do chamado período clássico, que para este povo a esfera ética e a estética eram complementares e indissociáveis. Tal relação se mostra evidente na pluralidade de acepções (estética, moral e epistemológica) do conceito do Belo (to kalón), o que faz com que este conceito tenha implicações não somente estéticas, mas morais e intelectuais no pensamento de filósofos como Sócrates e Platão. Ao basear-se na interpretação de Nunes quando declara que, entre os gregos clássicos, "A fruição da beleza, que participa tanto da inteligência quanto da sensibilidade, afeta moderadamente a alma. Ao contrário do gozo físico, ilimitado e instável, que leva à insatisfação permanente e ao desequilíbrio das paixões, o verdadeiro prazer estético, para os filósofos gregos que se ocuparam do Belo, é inseparável da medida e da contenção, virtudes impostas pelas faculdades superiores da alma. No Belo estético há, pois, uma antecipação das qualidades morais que o homem deverá possuir e expressar em seus atos" (NUNES, 2002, p. 18).

Desse modo, Poesia e Música, as artes das Musas, servir-se-iam para acalmar as paixões e não para despertá-las, pois é a serenidade e não a impetuosidade a condição

\footnotetext{
"significava, para os artistas da Roma antiga, exatamente o que significava para nós: o cânon de Policleto, uma regra perfeita da arte (WINCKELMANN, 1975, p. 40).

${ }^{114}$ É neste sentido que Winckelmann dirige o seu elogio a seu soberano, príncipe Frederico-Augusto pelo fato deste ter proporcionado o contato do homem e do artista alemão com obras dos mestres antigos. Com isso, afirma Winckelmann, este monarca teria contribuído para a imitação destas obras e, por conseguinte, para a formação do bom gosto entre os alemães. O historiador alemão escreve: "Visando a formação do bom gosto (Bildung des guten Geschmacks) - e isto constitui um monumento imperecível da grandeza desse monarca - os maiores tesouros da Itália, como também todas as obras-primas da pintura de outros países, são expostos aos olhos de todo mundo. Finalmente, seu afã de perpetuar as artes não conheceu descanso antes de ter proporcionado aos artistas, para fins de imitação, verdadeiras e autênticas obras de mestres gregos de primeira ordem" (WINCKELMANN, 1975, p. 39)
} 
mais favorável para a prática das virtudes, o que confere à arte finalidades morais e pedagógicas, bem como ao conceito de Belo uma acepção moral. No que concerne à Beleza estética, "será tanto melhor quanto mais correlacionada estiver com a de índole moral" (NUNES, 2002, p. 19). Em suma, para os gregos, ética e estética deveriam se unir de tal forma que jamais pudessem existir separadamente. Esta união, afirma Nunes (2002, p. 19), pode ser constatada no conceito grego de kalokagathia, ideal pedagógico da Grécia clássica que quer dizer: ser ao mesmo tempo belo e bom. Winckelmann parte deste ideal para pensar a dimensão ao mesmo tempo estético e ético do estilo, o que lhe permite entendê-lo como instrumento histórico-hermenêutico, mas também pedagógico na formação do homem moderno.

Contudo, a despeito desta ampliação semântica do conceito de estilo, Winckelmann não criou um conceito próprio de estilo, como o fez Goethe, e tampouco desenvolveu uma teoria profunda acerca da educação estética do homem, como o fez Schiller, haja vista que seus esforços se concentravam primeiramente na formação do artista. Porém, com as investigações históricas e estéticas, bem como o posicionamento estético, o autor das Reflexões abriu caminho para o pensamento estético-pedagógico do classicismo alemão vindouro, de modo particular o de Goethe e Schiller. Para o jovem Nietzsche, a reflexão de Winckelmann constitui o início de um movimento pela formação alemã, logo uma resposta à constituição bárbara da Alemanha dos séculos XVIII e XIX.

Com efeito, Nietzsche não foi o primeiro a utilizar os termos barbárie e bárbaro para se referir à Alemanha e ao povo alemão de seu tempo. Ao proceder deste modo, o filósofo reitera a crítica que há alguns anos Goethe já havia dirigido ao seu povo. Num escrito póstumo do período da juventude, Nietzsche afirma: "Poucos homens serão perdoados por se referirem ao seu povo como bárbaros. Mas Goethe o fez (...)" (Fragmento Póstumo I, 19 [305] do verão de 1872 - começo de 1873, KSA 7.512). Em outra anotação póstuma do mesmo ano, o jovem filósofo procura legitimar suas considerações acerca da barbárie alemã ao se apoiar na autoridade do poeta alemão. Nietzsche escreve:

Ademais, que os alemães todavia sejam bárbaros, era a opinião de Goethe, o qual chegou a ter a suficiente idade para poder dizer também aos alemães esta verdade, e sobre cujas palavras eu devo me permitir fundar minhas considerações, posto que, 
caso contrário, ninguém queria me autorizar (Nachlass/FP 18721873,19 [312], KSA 7.514).

É notório que, no contexto dos escritos juvenis de Nietzsche, Goethe apareça como um guia para a realização da crítica da cultura e, neste âmbito, as Gespräche Von Goethe mit Eckermann são frequentemente aludidas pelo jovem filósofo. Já nas primeiras páginas da sua Primeira Extemporânea Nietzsche reproduz o seguinte fragmento da referida obra:

Nós alemães somos de ontem; é verdade que há um século nos vimos cultivando [Kultiviert] de modo excelente; decorrerão porém ainda mais alguns até que espírito [Geist] e elevada cultura [höhere Kultur] penetrem em nossos patrícios e se generalizem; que eles, como os gregos, honrem a beleza; que se encantem numa bela canção e que deles se possa dizer: há muito deixaram de ser bárbaros [Barbaren]"115 (GOETHE, 1950, p. 237. Trad. modificada).

Goethe se refere aos seus compatriotas como bárbaros por acreditar que, a despeito do longo processo de cultivo, ainda falta ao alemão espírito e elevada cultura $^{116}$, bem como o sentimento para a beleza, condição que resulta da insuficiência formadora do povo alemão. Em conversa com Eckermann, o poeta reivindica um tipo de formação que, embora se inicie com o aperfeiçoamento (Ausbildung) individual, tenha como meta a totalidade cultural:

[...] é de se desejar o aperfeiçoamento coletivo [gemeisame Ausbildung ${ }^{117}$ ] das forças humanas, por corresponder aos anseios gerais. O homem, porém, não nasceu para isso; cada um

\footnotetext{
${ }^{115}$ Nietzsche reproduz a seguinte passagem com pequenas modificações em DS/Co. Ext. I, 1, KSA 1.159.

116 Como observa Frezzatti (2006, p.50-60), a palavra "cultivado", e com ela termos correspondentes como "civilizado", "polido" ou "disciplinado", eram designações com as quais a aristocracia européia diferenciava-se das classes inferiores, as "simples" ou "primitivas". Com efeito, tais termos expressam os bons hábitos e as boas maneiras da corte alemã em oposição aos modos rudes das classes inferiores. Não obstante, afirma Frezzatti, no âmbito da Alemanha da época de Goethe, o fato de um homem ser civilizado (zivilisiert) ou cultivado (kultiviert) não implica que ele tenha uma autêntica cultura (Kultur). A cultura, neste contexto, consiste numa instância superior a do cultivo e da civilização na medida em que não se reduz ao aperfeiçoamento de convenções e etiqueta, mas está relacionada ao desenvolvimento do espírito humano através das ciências, da religião e da arte. Sobre a oposição entre os conceitos de cultura (Kultur) e civilização (Zivilisation), cf. FREZZATTI, W. A Fisiologia de Nietzsche: a superação da dualidade cultura/civilização. Ijuí: Ed. Unijuí, 2006, especialmente o capítulo 1.

117 Utilizaremos o termo "aperfeiçoamento" para traduzir o termo alemão Ausbildung. No contexto em que se encontra, o conceito de Ausbildung está numa relação direta com o conceito de Bildung (formação) e com o de Erziehung (educação), pois é pelo aperfeiçoamento das forças humanas pela educação que se realiza a formação do homem.
} 
deve a rigor formar-se [bilden] como um indivíduo à parte, mas deve procurar alcançar a noção do que todos representam em conjunto" (GOETHE, 1950, p. 131).

Com efeito, ao considerar os anseios do povo e da cultura, a formação mais adequada deveria ser a que promovesse o aperfeiçoamento da totalidade das forças humanas constituindo uma personalidade harmoniosa, como ocorreu com a formação do homem grego antigo. Contudo, na medida em o homem moderno está impossibilitado de realizar tal formação, Goethe propõe que cada um se forme como um indivíduo, porém sem perder de vista o seu lugar na totalidade ${ }^{118}$. Assim, é improvável que um grande filósofo possa ser ao mesmo tempo um grande atleta; ou que um grande músico tenha tempo suficiente para desenvolver competências no campo da política. Seja como for, como filósofo ou atleta; músico ou político, o indivíduo deve se reconhecer como parte de um todo, só assim as suas ações terão como fim esta totalidade.

No entanto, segundo Goethe, este não é modelo de formação que predomina na Alemanha de seu tempo, época pronunciadamente subjetiva. De modo contrário, o modelo de formação predominante visa ao aperfeiçoamento da interioridade (Innerlichkeit) $^{119}$ e ao isolamento do indivíduo em relação ao exterior. Logo, se o alemão moderno não é capaz de realizar uma formação que vise à coletividade, é porque se encontra contaminado por aquilo que Goethe diagnosticou como a "doença comum da atualidade" (allgemeinen Krankheit der jetzigen Zeit): a subjetividade $(\text { Subjektivtät })^{120}$.

A oposição entre objetividade e subjetividade, que durante algum tempo dividiu as opiniões de Goethe e Schiller no que tange o procedimento poético, foi, segundo

\footnotetext{
118 Em vários momentos de sua reflexão, Goethe se mostra atraído pelo ideal da formação da personalidade harmoniosa, como ocorre nesta passagem das Gespräche, mas também em outros escritos como no ensaio sobre Winckelmann (1801). No entanto, afirmamos com Bruford (2009, p. 56) queo realismo de Goethe o impede de ter esperanças de que o homem moderno possa realizar tal ideal. Contra o otimismo expresso por Schiller nacarta VI de Sobre a educação estética do homem, a formação do homem pleno e harmônico foi algo atingido somente pelos antigos e, portanto, só a eles está reservado. Tomando como exemplo a personagem de Wilhelm dosLehrjahrede Goethe,Bruford escreve: "O realista Goethe reconheceu então que devemos nos contentar em educação, com algo menos do que 'restaurar a totalidade de nossa natureza', como Schiller havia exigido. Ele deixou Wilhelm, no final do Lehrjahre, ainda sem realizar o objetivo desejado, mas com a perspectiva de provar a si mesmo, na companhia de seu filho Felix, sua esposa Natalie e os amigos dela, e através da aceitação de uma tarefa limitada em matéria de sociedade civil, que seria uma pessoa razoavelmente cultivada em algum momento no futuro" (BRUFORD, 2009, p. 57). Sobre a noção goethiana de Bildung em Wilhelm Meister Lehrjahre cf. BRUFORD, W.H. The German Tradition of Self-Cultivation: 'Bildung' from Humboldt to Thomas Mann. Cambridge: Cambridge University Press, 2009.

${ }^{119}$ Cf. Goethe, 1950, p. 155.

${ }^{120} \mathrm{Cf}$. Goethe, 1950, p. 153.
} 
Goethe, o ponto de partida da querela entre clássicos e românticos. A Eckermann o poeta alemão argumenta:

A ideia de poesia clássica e romântica que corre o mundo hoje e que tantas contendas e divergências tem suscitado, partiu de mim e de Schiller. Eu seguia em poesia a máxima do procedimento do objetivo e só essa aceitava. Schiller, porém, que agia subjetivamente, considerava-se na justa atitude e para se defender contra mim escreveu o ensaio sobre a poesia ingênua e sentimental. Provou-me que mesmo sem o querer, eu era romântico, e que minha 'Ifigênia', pelo predomínio do sentimento, não é clássica e nem de gosto antigo como talvez se poderia supor. Os Schlegel apoderaram-se da ideia e divulgaram-na a tal ponto, que todos falam hoje em classicismo e romantismo, quando há cinqüenta anos ninguém pensava nisso. (GOETHE, 1950, p. 346).

A contraditória entre subjetivo e objetivo, para Goethe, pode ser rebatida noutros pares opositores como ingênuo e sentimental, clássico e romântico. Não obstante, todos eles estão relacionados à oposição entre interior e exterior ${ }^{121}$. Neste sentido, por subjetividade, Goethe entende o domínio da interioridade do sujeito, um domínio privado que está em plena oposição ao domínio da expressão objetiva da natureza. Quando se toma a poesia como exemplo, Werle explica que a dimensão subjetiva de uma poesia consiste no fato dela expressar um sentimento (Empfindung) ou uma vivência própria do poeta: “em todos os casos, implica uma demora junto a um objeto que servirá de ocasião para a expressão lírica, de modo que é o próprio caráter do poeta que desempenha um papel fundamental" (WERLE, 2013, p. 115-116). Na medida em que o homem moderno, como afirma Goethe, concentra tudo para o interior, ele sofre da moléstia da subjetividade.

Tal tendência se mostra evidente nos modos de proceder da ciência e das artes modernas, produções que, uma vez encerradas no âmbito da subjetividade perdem a sua conexão com a realidade exterior, logo, a relação com a vida. No que tange o universo da produção científica da modernidade, afirma Goethe, a visão do mundo estreita e

\footnotetext{
${ }^{121}$ A oposição entre os domínios do interior e do exterior do sujeito é de procedência cristã, bem como a primazia do primeiro em detrimento do segundo. Segundo Mattéi, este predomínio da interioridade se afirmará como sendo a característica principal da época moderna. O pesquisador francês afirma: "Poderse-ia mesmo afirmar que o caráter principal da Modernidade, pelo qual ela se distingue radicalmente da Antiguidade, provém dessa passagem insensível da substancialidade à subjetividade ou, para dizer numa linguagem menos severa, da passagem da alma ao eu e, ao mesmo tempo, da passagem da exterioridade à interioridade (MATTÉI, 2002, p.147).
} 
parcial dos teóricos ocasionada pela amplitude do cabedal das investigações e pela crescente especialização pode comprometer a pureza do objeto, já que ela está sempre atravessada pela subjetividade. O poeta alemão argumenta: "Se esses sábios dão contas de suas percepções, apesar do acendrado amor de cada um pela verdade, não encontramos todavia a realidade objetiva e de forma alguma o objeto em sua realidade, mas apenas com um sabor acentuadamente subjetivo (...) Nestas pessoas tudo deriva para o seu interior" (GOETHE, 1950, p. 90).

Tal como a ciência, o âmbito da produção artística receberá a mesma crítica de Goethe, uma vez que também se encontra afetado por esta inclinação à subjetividade. Enquanto elege como princípio supremo da produção artística a recusa da tradição, o artista moderno direciona todo o seu esforço produtivo para a afirmação de seu próprio ego. Goethe afirma: "É de lastimar-se, em Arte, que ninguém se queira regozijar com aquilo que já existe, e sim com o que cada um por sua vez pretende produzir". E acrescenta: “(...) E não há, além disso, um sereno esforço que vise às conveniências da coletividade (...) Todos tratam apenas de, na medida do possível, evidenciar o seu próprio ego perante a sociedade" (GOETHE, 1950, p. 129-130).

A tendência à subjetividade, para Goethe, é o que caracteriza época moderna. Desta perspectiva, o homem moderno surge em plena oposição ao grego clássico, formado em uma época marcada pela objetividade. Neste sentido, em tom de revelação, o poeta diz a Eckermann: "Todas as épocas em retrocesso e dissolução são subjetivas, ao passo que os tempos em franca evolução apresentam tendência acentuadamente objetiva (...). Nossa era atual é retroativa por ser pronunciadamente subjetiva (...)" (GOETHE, 1950, p. 154, trad. modificada). A objetividade, portanto, é o que caracteriza as grandes épocas; é o traço mais marcante das épocas realmente produtivas e progressivas cujo exemplo mais contundente foi a Grécia clássica. Nesse momento, afirma o poeta alemão, em todos os setores da produção humana cada esforço verdadeiro se movimenta do interior do homem para o exterior.

Por outro lado, a "moléstia" da subjetividade, mazela que faz da modernidade uma era retroativa, é também o que faz do alemão um povo de bárbaros e, por conseguinte, um povo de “ontem”. Uma nação de bárbaros, pois, encerrado nos limites de sua interioridade, o alemão se formou como um indivíduo isolado e sem conexão alguma com a exterioridade, incapaz de ver a si mesmo como parte de um todo. Um 
povo de "ontem", pois, quanto mais o alemão se encarcerou em sua interioridade, menos importância deu à vida prática e, neste sentido, menos produtivo se fez ${ }^{122}$.

À guisa de exemplo, Goethe afirma que um poeta quando se expressa subjetivamente os sentimentos não é verdadeiramente um poeta, mas ele sê-lo-á “(...) se tiver integrado no mundo real e souber expressá-lo" (GOEHTE, 1950, p. 154), ou seja, quando aprender a proceder de maneira objetiva. Não obstante, o único caminho possível para que o artista moderno aprenda a agir deste modo é o contato com as obras de arte dos clássicos gregos. Nesta acepção, ao artista moderno, Goethe sugere: "concentra-te no mundo real e procura exprimi-lo, pois assim procediam os antigos que nele viviam" (GOETHE, 1950, p. 154). Assim, ao se basear na trilha aberta por Winckelmann, Goethe sugere a formação do artista moderno através do contato com a obra de arte dos clássicos. Contudo, diferente do autor das Reflexões, Goethe não exorta o artista a imitar as obras clássicas, mas a imitar o modo de proceder dos clássicos, isto é, como os gregos alçaram da imitação simples da natureza real ao belo ideal, ou seja, ao "estilo" (Stil).

No ensaio Imitação simples da natureza, maneira, estilo, de 1789 , o poeta alemão revela a necessidade nada supérflua de se indicar, com precisão, aquilo que pensa quando se utiliza a palavra estilo ${ }^{123}$. E pouco mais adiante, escreve:

\footnotetext{
${ }^{122}$ Da perspectiva histórica, não podemos deixar de mencionar o considerável atraso da Alemanha em relação à Inglaterra e à França no que diz respeito às transformações políticas e ao desenvolvimento econômico. Acontecimentos como a Revolução Inglesa de 1640 e a Revolução Francesa de 1789 contribuíram para que a democracia moderna e o modo de produção capitalista irrompessem primeiramente nestes dois países para somente um século depois iniciar na Alemanha. Neste sentido, Silva (2007, p. 68) sugere que o relativo atraso político e econômico da Alemanha em relação aos seus vizinhos marcou significativamente a vida intelectual alemã ao difundir a ideia de que o desenvolvimento da nação alemã deveria estar condicionado ao aperfeiçoamento cultural dos seus mandarins, termo utilizado de maneira pejorativa por Fritz K. Ringer para caracterizar uma parte culta alemã constituída por "(...) médicos, advogados, clérigos, funcionários do governo, professores de escolas secundárias e professores universitários, todos eles com diploma de curso superior (...)" (RINGER, 2000, p. 22). Blindados pelo reconhecimento da sociedade civil alemã, argumenta Silva, os intelectuais puderam afirmar as idiossincrasias alemãs e, dentre elas, a mais característica: a interioridade. Silva escreve: "O traço principal dessas especificidades é a famosa 'interioridade' alemã, que se aprofunda com a inexistência de um mundo "exterior"' (SILVA, 2007, p. 69). Na medida em que a interioridade alemã vai sendo cada vez mais afirmada, mais os intelectuais alemães se afastam da ordem política e do compromisso com a vida prática, tendência que se manifesta no idealismo alemão. Retroativo, alheio à vida exterior e às relações materiais, o povo alemão faz da Alemanha uma nação cada vez mais atrasada no processo civilizatório.

${ }^{123}$ Nas primeiras linhas do ensaio de 1789 lê-se: "Não parece supérfluo indicar precisamente o que pensamos com estas palavras que empregaremos com frequência. Pois mesmo que há muito tempo em textos já se tenha feito uso delas, mesmo que pareçam estar determinadas por escritos teóricos, na maioria das vezes todo mundo as emprega em um sentido próprio e com elas pensa ora uma, ora outra coisa, quanto mais forte ou fracamente apreendeu o conceito, que deve ser deste modo expresso" (GOETHE, 2009, p. 67).
} 
Se a arte, por meio da imitação da natureza, por meio do esforço, logra constituir uma linguagem universal, chega por fim, por meio do estudo atento e profundo dos objetos mesmos, a conhecer sempre mais exatamente as propriedades das coisas e o modo como subsistem, de tal forma que se abstrai da série das formas e sabe colocá-las lado a lado e imitar as formas características diversas: então o estilo torna-se o grau mais elevado que ela pode alcançar, o grau no qual ela tem o direito de se igualar aos supremos esforços humanos (GOETHE, 2009, p. 69).

Como resultado de um procedimento mimético que ultrapassa a condição de mera cópia da natureza sensível para lograr uma linguagem universal e objetiva através da razão, o conceito goethiano de estilo se encontra na esteira da imitação de Winckelmann. Como este, Goethe toma a imitação como princípio supremo para toda produção artística que anseie pela realização do belo ideal, o que significa dizer do estilo. Enquanto Winckelmann se mostra pessimista no que diz respeito à possibilidade do artista moderno atingir o belo ideal parte da imitação da natureza, ao incentivá-lo, portanto, à imitação das obras clássicas, Goethe vê com otimismo tal possibilidade e aposta no talento e na força produtiva do artista moderno.

Desta forma, a "imitação simples da natureza" (Einfache Nachahmung der Natur) se mostra como o primeiro passo do artista em direção ao estilo. Goethe escreve:

A imitação simples da natureza, portanto, trabalha, por assim dizer, no átrio do estilo. Quanto mais fiel, cuidadosa e puramente proceder com as obras, quanto mais calmamente observar o que sente, quanto mais tranquilamente o imitar, quanto mais ela nisso se acostuma a pensar, isto é, quanto mais aprender a comparar o que é semelhante e a separar o dessemelhante entre as coisas e a ordenar objetos isolados sob um conceito universal, tanto mais digna ela se tornará de pisar a soleira do santuário (GOETHE, 2009, p. 71).

Por estilo, Goethe entende o estado mais elevado da arte e, desse modo, essa tendência é o resultado de um procedimento que depende, antes de tudo, da capacidade e do talento de um tipo especial de artista, o gênio: o que pensa e estuda de maneira calma e atenta os objetos naturais de forma a conhecer profundamente suas propriedades e o modo como estes subsistem; mas, sobretudo, o que é dotado de uma capacidade singular para elevar os objetos reais individuais a um estatuto ideal e universal. Eis o motivo que leva Goethe a afirmar que um pintor, ao imitar a natureza 
será ainda melhor e mais talentoso se for também um botânico versado ${ }^{124}$, pois só o artista que pensa e conhece profundamente a natureza pode reduzir a multiplicidade caótica dos objetos naturais que lhe saltam aos olhos à ordem e à harmonia, ao revelar uma beleza mais elevada e ideal do universo ao seu redor.

Dessa maneira, o artista genial produz o estilo na medida em que submete a multiplicidade do mundo sensível à unidade da razão, enquanto constrói sua obra como uma totalidade perfeita e ideal. Para Goethe, o que eleva a arte do estatuto inferior da imitação simples da natureza ao seu grau superior, o estilo, é a "maneira" (Manier) ${ }^{125}$, modo subjetivo e individual de proceder. É a, portanto, intersecção entre esses dois estágios da obra de $\operatorname{arte}^{126}$. O poeta escreve:

Quanto mais em seu método mais leve ela [a maneira] se aproximar da imitação fiel, quanto mais assiduamente procurar, do outro lado, apreender o que é característico nos objetos e expressá-lo de modo captável, quanto mais ligar ambos por meio de uma individualidade pura, vivaz e ativa, tanto mais ela se tornará elevada, maior e respeitosa (GOETHE, 2009, p. 71).

A maneira deve ser o elo necessário entre a imitação simples da natureza e o estilo, mas não deve passar disso. Do contrário, quanto mais o artista deixar de se ater à natureza sensível e à natureza ideal, quanto mais deixar transparecer sua subjetividade na obra, mais longe estará da fundação da arte e seu modo será destituído de sentido ${ }^{127}$. Ao levar em conta o talento e o sentimento do artista, enfim, sua forma como uma das etapas do percurso que leva ao estilo, Goethe se afasta do conceito de imitação de Winckelmann que não admitia tais elementos em arte ${ }^{128}$.

\footnotetext{
${ }^{124}$ Cf. Goethe, 2009, p. 70.

${ }^{125} \mathrm{O}$ termo "maneira" (em alemão Manier) deriva do latim maniera. O termo passa a ser utilizado na literatura italiana sobre arte do século XVI ainda como uma designação valorativamente indiferente. Em Le vite de' più eccellenti pittori, scultori e architettori(1550) deGiorgio Vasari (1511-1574), o termo se refere ao modo de produção característico de cada artista. No âmbito do classicismo alemão, Goethe recorre ao termo Manier para designar um tipo de arte ainda demasiado presa à subjetividade do artista, porém lhe confere um juízo respeitável na medida em que consiste numa etapa necessária da formação do artista que pretende chegar à objetividade do estilo. Contrário à Goethe, Schiller entenderá o procedimento da Manier a partir de um juízo desaprovador Cf. Goethe, 2009, p. 71; Schiller, 2002, p.114. ${ }^{126}$ Concordamos com Werle quando afirma que Goethe, com as noções de imitação simples da natureza, maneira e estilo, não pretendia se referir a três tipos distintos de artistas, tampouco de escolas diferentes. Para Werle, também não se trata de padronizar a atividade artística a partir destas noções ou de afirmar um modelo: "Trata-se, isto sim, de fazer valer diferentes formas que se interpenetram" (WERLE, 2013, p. 110).

${ }_{127}$ Cf. Goethe, 2009, p. 71

${ }^{128}$ Um exemplo disso, segundo Goethe, é Rafael. No ensaio Antigo e moderno, Goethe escreve: "Ele jamais greciza, mas sente, pensa e age completamente como um grego. Nós vemos aqui o mais belo talento, desenvolvido num período igualmente feliz como o que ocorreu, sob circunstâncias análogas, na
} 
No que se refere à produção da bela arte, Goethe se aproximará da noção de "imitação formadora do belo" (bildende Nachahmung des Schönen) de Karl Philipp Moritz, que entende o belo elevado como o produto de uma força formadora do artista capaz de criar a partir do sentimento e da observação atenta dos objetos sensíveis, ordinários e vulgares, a forma mais perfeita e elevada ${ }^{129}$ de arte. Com efeito, o estilo, como realização do belo ideal, é algo possível somente ao gênio, um tipo de artista ainda inédito na época de Goethe, porém com os meios e os caminhos já preparados para o seu surgimento. A Eckermann, o poeta confessa o seu otimismo:

Faz-se mister o advento de um gênio que se aproprie logo do que há de bom na atualidade, assim excedendo a tudo mais. Os meios aí estão todos, os caminhos indicados e aplainados. Temos até mesmo as obras de Fídias ante os olhos, no que nem se podia pensar, em nossa juventude. Falta agora, como disse, um grande talento, e esse está por vir, assim o espero. Talvez viva já em seu berço, e você ainda o verá em sua glória (GOETHE, 1950, p. 168).

Quando se trata dos meios necessários para a formação do gênio, Goethe se refere à grande quantidade de obras de arte do período clássico, bem como cópias de obras deste período e que, naquele momento, encontravam-se disponíveis para a contemplação do artista alemão. Em obras de arte como as de Fídias, o artista moderno poderá contemplar exemplos notáveis do ideal clássico de beleza: a proporção e harmonia entre as partes de modo a compor uma totalidade. O contato com este ideal através das obras clássicas é, para Goethe, o meio necessário para a formação do gênio; o caminho é a imitação, não da obra, mas do seu ideal. Dessa maneira, o artista genial deve buscar fora de seu tempo, na Grécia clássica, o modo adequado para expressar o seu tempo e eternizá-lo.

Com efeito, esta forma adequada de expressão é o que Goethe designa por estilo. Posto isto, é característico do gênio, bem como de sua arte, a extemporaneidade. Em

época de Péricles" (GOETHE, 2009, p. 232). Desse modo, em detrimento da orientação de Winckelmann de que, para aprender o ideal clássico, deve-se necessariamente imitar os antigos, em Antigo e moderno o poeta alemão nos apresenta a ideia radicalmente distinta de que o essencial consiste em seguir o talento próprio: "Que cada um seja à sua maneira um grego! Mas que ele o seja"(GOETHE, 2009, p. 232).

129 Goethe manteve contato pessoal com Moritz durante a temporada romana (1786-1788), chegando a escrever uma resenha sobre a obra de Moritz Über die bildende Nachahmung des Shönen (Sobre a imitação formadora do belo) de 1788. Sobre a resenha de Goethe, cf. "Sobre a imitação formadora do belo de Moritz". In: GOETHE, J.W. Escritos sobre arte. Trad. Marco Aurélio Werle. São Paulo: Humanitas/Imprensa Oficial, 2008).Sobre a influência de Moritz no pensamento de Goethe Cf. MAAS, Wilma Patricia. A bela alma e a estética goethiana do símbolo. Viso - Caderno de estética aplicada. Rio de Janeiro, $N^{\circ}$ 9, jul-dez 2010. 
relação a um quadro de Correggio, Goethe afirma: "Uma pintura dessas é eterna, porque se relaciona tanto com os tempos mais primitivos da humanidade como com os futuros" (GOETHE, 1950, p.168). Por isso, é no estilo que a arte encontra sua autonomia e independência, isto é, encontra-se livre das determinações da natureza sensível, bem como da subjetividade do artista e do caráter do seu tempo, uma vez que ultrapassa a realidade atual na constituição do belo ideal, logo é a própria expressão da liberdade.

Pode-se, portanto, criar um paralelismo entre o procedimento goethiano de formação do gênio artístico e o procedimento de formação do homem na constituição daquilo que o poeta alemão chamou de "Bela alma" (schoene Seele). Neste sentido, afirma-se que, assim como o artista genial deve buscar a sua formação nas obras de arte clássicas, de estilo, o homem comum também pode atingir uma formação harmônica pelo mesmo meio. Para tanto, é necessário um procedimento pedagógico capaz de harmonizar as partes do homem de forma a compor uma totalidade, enfim, uma educação que vise o espírito sem perder de vista o corpo, mas que ao mesmo tempo eduque o corpo sem subtrair o espírito. É necessária, em última análise, uma educação estética do homem por meio da arte de estilo.

O livro VI de Os anos de aprendizado de Wilhelm Meister ${ }^{130}$, que tem por subtítulo "Confissões de uma bela alma", narra as vivências de uma personagem anônima ${ }^{131}$, desde suas experiências primevas de infância até as de sua maturidade. Tal percurso é marcado por alguns acontecimentos decisivos para a formação da Bela alma. Primeiramente, ainda criança, a personagem é acometida de uma doença que acaba por afastá-la do universo das brincadeiras infantis quando a aproxima de leituras científicas, literárias e religiosas que lhe eram oferecidas por entes familiares. O segundo acontecimento diz respeito ao primeiro contato com o amor sensível representado na personagem de Narcisse, o noivo. Tais vivências serão determinantes na medida em que fomenta a libertação do seu espírito das determinações do mundo material. A consequência deste isolamento social foi o completo desapego dos jogos e diversões mundanos, e a substituição do amor sensível que nutria pelo noivo pelo amor ideal por

\footnotetext{
${ }^{130}$ Os anos de aprendizado de Wilhelm Meister, publicado entre os anos de 1795 e 1796, inaugura na literatura mundial aquilo que mais tarde foi chamado de "romance de formação" (Bildungsroman), termo utilizado pela primeira vez por Karl Morgenstern (1770-1852), numa conferência proferida em 1810 intitulada "Sobre o espírito e a relação de uma série de romances filosóficos" (Cf. Mazzari, 2009, p. 7).

${ }^{131}$ Embora tais "confissões" se apresentem no âmbito de uma obra de ficção, o livro VI reproduz, numa versão romanceada, os escritos da pietista Susanna Katharina von Klettenberg, parente e amiga da família de Goethe, bem como prováveis conversas que esta teve com o poeta alemão. Em 1912, os escritos de Klettenberg serão reunidos e publicados sob o título A bela alma: confissões, escritos e cartas de Susanna Katharina von Klettenberg.
} 
Deus. Porém, o acontecimento mais decisivo vir-se-ia: o contato com o tio Philo, homem nobre e distinto que a introduz no universo da contemplação artística, de modo que a personagem compreendesse a arte como um meio sensível para a contemplação de Deus. Na voz da Bela Alma, o poeta afirma:

Dirigiu (Philo) minha atenção para os diversos quadros pendurados na parede; meus olhos se detinham naqueles cujo aspecto era atraente ou significativo o assunto; ele esperou um momento, antes de me dizer:

- Conceda também alguma atenção ao gênio que criou essas obras. As boas almas gostam de ver na natureza o dedo de Deus; por que não devemos dispensar também alguma consideração à mão daquele que o imita? (GOETHE, 2009, p. 393).

A iniciação na arte afirma a importância de formar o gosto para a constituição da bela alma, o que revela um paralelismo entre o processar do gênio e do homem por meio da arte. Tal como proposto no ensaio de 1789, em que o processo de produção artística ideal aparece marcado quando se supera a imitação simples dos objetos sensíveis da natureza e da maneira pelo estilo, forma idealizada da natureza, a personagem se inicia com o afastamento gradual do mundo sensível e de seu estado natural e a aproximação de Deus. No entanto, assim como o estilo resulta da fusão entre o sensível e o racional, o ciclo da formação da bela alma só estará completo na medida em que a moral extrapole o âmbito da interioridade e da fé e se dirija ao mundo exterior, não o da natureza real, mas o da natureza idealizada pelo gênio, isto é, pela arte de estilo. Assim, a arte de estilo é apresentada como um suporte sem a qual estaria incompleta a formação do homem, o que implica num vínculo necessário entre a formação do espírito e do corpo, entre a educação moral e a estética. Através de Philo, Goethe diz:

- A senhora tem completa razão, e daí constatamos que não está bem entregar-se à educação moral, solitário e ensimesmado; antes descobriremos que aquele cujo espírito anseia por uma formação moral tem todas as razões para educar ao mesmo tempo sua mais fina sensibilidade, a fim de não correr o risco de despencar do alto de sua moral, entregando-se às tentações de uma fantasia desregrada e chegando ao caso de degradar sua natureza mais nobre mediante o prazer em brincadeiras insípidas, quando não em algo ainda pior (GOETHE, 2009, p. 394). 
A formação moral solitária e introspectiva da religião não dá conta de realizar a plenitude do homem moderno, que, diferente dos gregos ${ }^{132}$, revela-se como um ser fragmentado, cindido entre alma e corpo, entre razão e sensibilidade. Desse modo, ele pode a qualquer momento cometer excessos, ou por parte do espírito, ao incorrer em delírios e fantasias, ou por parte do corpo, quando se entrega a prazeres efêmeros. Uma formação plena do homem, portanto, deve considerar tanto a educação do espírito quanto a do corpo, logo o estilo se torna o ponto de partida para isso, pois representa uma totalidade na união entre natureza sensível do objeto imitado e a natureza ideal do artista.

Em suma, a tendência à subjetividade, ao fomentar o aperfeiçoamento do homem interior promove, ao mesmo tempo, a sua cisão com o exterior ao impedir que o povo se realize na cultura da Alemanha de seu tempo. Desta forma, a barbárie, como signo da desagregação social em que se encontra a Alemanha de Goethe, revela-se como o oposto daquilo que o poeta alemão designa por espírito e alta cultura, expressões da harmonia individual e da realização do todo social. O contato com a cultura grega e com a obra de arte de estilo, para Goethe, na medida em que ensina o homem moderno a proceder de maneira objetiva, mostra-se como um meio eficaz contra a "doença da subjetividade" e, neste sentido, o estilo se mostra como um elemento fundamental para uma ideia de educação estética do homem, logo um elemento indispensável à formação. Próximo de Goethe, porém amparado pelo criticismo kantiano, o pensamento de Schiller também se mostrará fundamental para compreender o tema da formação do homem, bem como a sua relação com o tema do estilo.

Schiller considera que, a despeito de todo cultivo e todo ensinamento (Aufklärung) $)^{133}$, bem como de todo o movimento que a razão operou ao desconstruir as ilusões e fantasias que turvam o conhecimento humano, o homem moderno ainda

\footnotetext{
132 É característico do pensamento de Goethe, e do romantismo alemão de um modo geral, considerar o homem moderno como um ser fragmentado, isto é, marcado pela cisão entre o corpo e o espírito, razão e sensibilidade. $\mathrm{O}$ aspecto essencial da "volta aos gregos" no classicismo e no romantismo alemão é por estes enxergarem nos gregos modelos supremosdo homem pleno, no qual o corpo e espírito são elementos complementares e indissociáveis. Esta totalidade teria sido idealizada pelos gregos e alcançada pela rigorosa formação (paideia) e pelo duplo aspecto da educação, que desde a Grécia arcaica consistia na educação oferecida pelo paidotribes, mestre da ginástica, e pelo kitharistes, mestre da música. Vale mencionar a proposta platônica de formação da juventude para sua república ideal, a qual consistia no ensino da ginástica para o cultivo do corpo (finalidade estética), eno estudo da música para a harmoniosa conformação da alma (finalidade moral).

${ }^{133}$ Cf. nota 02 .
} 
permanece bárbaro ${ }^{134}$. Em A educação estética do homem, Schiller indaga: "De onde vêm, pois, esse domínio ainda tão geral dos preconceitos e esse obscurecimento das mentes a despeito de toda luz que a filosofia e experiência acenderam? (...) - onde reside, pois, a causa de ainda sermos bárbaros?" (SCHILLER, 2002, p. 46). Para Schiller, a causa do alemão moderno ainda permanecer na condição de bárbaro está na sua formação (Bildung) precária ${ }^{135}$, que resulta de um conceito unilateral de educação (Erziehung) que prioriza a ilustração do entendimento (Aufklärung des Verstandes) quando deveria priorizar o aperfeiçoamento da sensibilidade (Ausbildung des Empfindungsvermögens) ${ }^{136}$.

Todo indivíduo "real", afirma Schiller em A educação estética do homem, "traz em si, quanto à disposição e destinação, um homem ideal e puro, e a grande tarefa de sua existência é concordar, em todas as suas modificações, com sua unidade inalterável" (SCHILLER, 2002, p. 28). Nesta perspectiva, a constituição do homem se encontra dividida entre duas forças antagônicas: a natureza que almeja a dissipação e a multiplicidade; a razão, que impele o indivíduo à unidade ideal. No homem antigo, de modo particular o grego da época clássica, estas duas forças coexistiram harmoniosamente ao formar um homem pleno. De maneira distinta se formou o homem moderno, em que esta plenitude se fragmentou quando dividiu o homem em "natural" e “ideal". O homem natural é o homem empírico e "real", pois o domínio da natureza é o da sensibilidade. Em contraposição, o homem racional é o homem "ideal”, pois o domínio da razão é domínio do pensamento, das leis e princípios. Não obstante, a fragmentação interior do homem, segundo Schiller, é um reflexo do fragmentar da própria cultura (Kultur) ${ }^{137}$. Na Carta VI, Schiller argumenta:

Tão logo a experiência ampliada e o pensamento mais preciso tornaram necessária uma separação mais nítida das ciências, assim como, por outro lado, o mecanismo mais intrincado dos Estados tornou necessária uma delimitação mais rigorosa dos estamentos e dos negócios, rompeu-se a unidade interior da natureza humana e uma luta funesta separou as suas forças harmoniosas (SCHILLER, 2002, p. 36-37).

\footnotetext{
${ }^{134}$ Cf. Schiller, 2002, p. 47.

${ }^{135}$ Cf. Schiller, 2002, p. 28.

${ }^{136}$ Cf. Schiller, 2002, p. 47.

${ }^{137}$ Cf. Schiller, 2002, p. 36-37.
} 
Para Schiller, a unidade cultural fragmentada de um lado no âmbito científico e de outro pela fragmentação do corpo político, refletiu no homem de modo a promover um conflito entre as suas faculdades especulativas e intuitivas. Em outros termos, desfez-se a harmonia que outrora havia entre o entendimento intuitivo (intuitive Verstand) e o especulativo (spekulative Verstand), e uma oposição belicosa se instalou entre o âmbito da especulação e o da intuição. Deste modo, afirma Schiller, "cada um deu a si mesmo um senhor que não raro termina por oprimir as demais potencialidades" (SCHILLER, 2002, p.37).

Desde então, pensamento e sensibilidade são concebidos como instâncias opostas e incompatíveis ${ }^{138}$. Schiller escreve: “(...) a partir da exclusão do sentimento, enquanto se pensa, e do pensamento, enquanto se sente, poder-se-ia concluir uma incompatibilidade das duas naturezas (...)” (SCHILLER, 2002, p. 128). Tal incompatibilidade teria contribuído para uma formação deficitária do homem que doravante se tornou incapaz de se formar como uma totalidade: "Eternamente acorrentado a um pequeno fragmento do todo", afirma Schiller, "o homem só pode formar-se (bildet) enquanto fragmento (...)" (SCHILLER, 2002, p. 37).

Esta precariedade derivada da oposição entre razão e natureza, pode se apresentar no homem, de dois modos. Schiller escreve: “O homem, entretanto, pode ser oposto a si mesmo de duas maneiras: como selvagem (Wilder), quando seus sentimentos imperam sobre seus princípios, ou como bárbaro (Barbar), quando seus princípios destroem seus sentimentos" (SCHILLER, 2002, p. 29). Assim, o bárbaro schilleriano, como oposição ao tipo selvagem, é aquele cuja razão suplanta os sentimentos ao ignorar o que há de natural no homem. Enquanto o selvagem toma a natureza como soberana e age segundo a sua cega necessidade e arbítrio, "o bárbaro", afirma Schiller, "escarnece e desonra a natureza" (SCHILLER, 2002, p. 29) ao agir unicamente sob o imperativo da razão.

Deveras, o homem se torna bárbaro na medida em que, no ímpeto de abandonar seu estado natural, em que impera a cega necessidade e determinação, entrega-se ao rigor de seus princípios racionais e de seu caráter ético. Não obstante, o sacrifício do caráter natural pelo ético não é indício de uma formação ideal do homem, mas sim de uma formação precária. Schiller escreve: "Daí ser sempre testemunho de uma formação (Bildung) ainda precária se o caráter ético só se afirmar com o sacrifício do natural (...)”

${ }^{138}$ Cf. Schiller, 2002, p. 37. 
(SCHILLER, 2002, p. 28). À formação precária do homem moderno, soma-se a constituição imperfeita de um Estado constituído de partículas sem vida ${ }^{139}$.

O Estado, para Schiller, é forma objetiva do homem ideal. Dito de outro modo, ele é a representação na qual a multiplicidade dos sujeitos tenta se unificar, o que pode ocorrer de dois modos: ou pela opressão do homem natural (empírico) pelo homem ideal, o que se dá quando o Estado suprime os indivíduos através da força da lei; ou quando o indivíduo se torna Estado, o que pode ocorrer quando o homem se "enobrece" através da beleza em direção ao homem ideal ${ }^{140}$. Na primeira hipótese temos um Estado cuja concepção de educação teórica prioriza o caráter ético e sacrifica o natural; na segunda, um Estado resultado de uma concepção de educação estética que prioriza o aperfeiçoamento da sensibilidade (Ausbildung des Empfindungsvermögens) vislumbrando a formação de um homem total.

Em linhas gerais, a educação teórica atua de modo a promover 0 aperfeiçoamento separado das forças humanas (getrennte Ausbildung der menschlichen Kräfte), pois ao mesmo tempo em que fomenta a ilustração do entendimento (Aufklärung des Verstandes), tende a suplantar a sensibilidade assim q renega aquilo que há de natural no homem. Em vista disto, o procedimento teórico e abstrato sacrifica a totalidade do homem e, por conseguinte, compromete a constituição do Estado, pois um país cujos homens são formados de modo unilateral, ao privilegiar a razão em detrimento da natureza, possui necessariamente uma constituição também imperfeita. Na Carta IV, Schiller escreve: “(...) e é ainda muito imperfeita uma constituição do Estado que só seja capaz de produzir a unidade pela supressão da multiplicidade" (SCHILLER, 2002, p. 28).

Diferentemente de Goethe, Schiller não associa esta formação precária do bárbaro à valorização do princípio da subjetividade em detrimento da objetividade, mas sim ao Estado que, ao principiar-se na objetividade da ideia, oprime o que há de subjetivo no homem pelo sacrifício da natureza em nome dos princípios éticos e morais: “O Estado não deve honrar apenas o caráter objetivo e genérico nos indivíduos, mas também o subjetivo e específico; não deve, ao ampliar o reino invisível dos costumes, despovoar o reino dos fenômenos" (SCHILLER, 2002, p. 28). Para o poeta de Jena, ao

\footnotetext{
${ }^{139}$ Comparado com o Estado grego, afirma Schiller, o Estado moderno se mostra como uma composição de partículas sem vida. Schiller escreve: "A natureza de pólipo dos Estados gregos, onde cada indivíduo gozava uma vida independente e podia, quando necessário, elevar-se à totalidade, deu lugar a uma engenhosa engrenagem cuja vida mecânica, em sua totalidade, é formada (bildet) pela composição de infinitas partículas sem vida" (SCHILLER, 2002, p. 36).

${ }^{140}$ Cf. Schiller, 2002, p. 28.
} 
suplantar o homem subjetivo pelo objetivo, o Estado humilha a individualidade do homem, pois ainda que o retire do reino da natureza e da cega necessidade, não é capaz de fazê-lo sem lhe imputar o arbítrio e o rigor da lei e da razão. Nas palavras de Schiller: “(...) o Estado empunhará contra o cidadão o severo rigor da lei e deverá, para não ser sua vítima, espezinhar sem consideração uma individualidade tão hostil" (SCHILLER, 2002, p. 29).

Dessarte, é necessário que o Estado, ao promover a educação do homem, não perca de vista a totalidade de sua constituição, ou seja, não opere de modo a desconsiderar a sua força racional, com o risco de formar os indivíduos como selvagens, e tampouco sua força natural, com o risco de formá-los como bárbaros ilustrados. Em ambos os casos, o homem não supera a sua condição de escravo, bem como o Estado a condição de privação. Uma educação adequada, portanto, deve atuar de modo a restaurar a harmonia e o equilíbrio entre estas duas potencialidades a fim de constituir uma totalidade. Por este motivo, "a força vitoriosa", afirma Schiller, "repousa a igual distância da uniformidade e da confusão", ou seja, da unidade moral e da multiplicidade natural. Segundo o filósofo de Jena: "É preciso, portanto, encontrar totalidade de caráter no povo, caso este deva ser capaz e digno de trocar o Estado da privação (Staat der Not) pelo Estado da liberdade (Staat der Freiheit)" (SCHILLER, 2002, p. 30).

Para Schiller, toda a melhoria política depende do enobrecimento do caráter humano. Em sua Carta IX, Schiller questiona “(...) - mas como o caráter pode enobrecer-se sob a influência de uma constituição do Estado bárbara (barbarischen Staatsverfassung)?” (SCHILLER, 2002, p. 49. Trad. Modificada). Em outros termos, como o homem pode deixar de ser bárbaro se é formado em meio à barbárie? Como romper o círculo entre a formação precária e o Estado bárbaro? Para a quebra deste ciclo, Schiller sugere a utilização de um instrumento que o Estado não forneça, só assim será possível a abertura de possibilidades inéditas, ou seja, "fontes que se conservem limpas e puras", isentas de toda corrupção política. "Este instrumento", afirma Schiller, "são as belas-artes (schöne Kunst). Estas fontes nascem em seus modelos imortais" (SCHILLER, 2002, p. 49).

O conceito de educação mais adequado ao homem moderno deve ser aquele que promova o aperfeiçoamento da sensibilidade, numa palavra, a educação estética. Para Schiller, "O aperfeiçoamento da sensibilidade é, portanto, a necessidade mais premente da época" (SCHILLER, 2002, p. 47. Trad. modificada), e é no contato com a 
beleza ${ }^{141}$ imortal contida nas obras clássicas dos gregos que ocorrerá o enobrecimento da sensibilidade do homem natural ao elevá-lo ao ideal, bem como a integração deste homem à totalidade da cultura ${ }^{142}$. Dessa maneira, a superação da dicotomia entre o entendimento e a sensibilidade e, por conseguinte, da barbárie, só é possível a partir de uma educação estética do homem, o que significa realizar o aperfeiçoamento da sensibilidade humana a partir da fruição da bela arte, ou nas palavras de Schiller, do estilo.

Em uma carta enviada à Körner ${ }^{143}$ em 1 de março de 1793, Schiller afirma que o estilo "nada mais é do que a suprema independência da apresentação perante todas as determinações subjetiva e objetivamente contingentes" (SCHILLER, 2002, p. 114). O estilo, portanto, consiste numa apresentação livre, isto é, que não se encontra

\footnotetext{
${ }^{141} \mathrm{O}$ conceito schilleriano de beleza marca sua posição em relação aos estetas sensualistas e racionalistas de seu tempo. Schiller escreve: "Todas as disputas referentes ao conceito de beleza que tenham dominado o mundo filosófico e que, em parte, ainda o dominam não têm outra origem senão no fato de que ou se iniciou a investigação sem uma distinção adequada e rigorosa ou ela não culminou numa ligação de todo pura. Aqueles filósofos que se entregam cegamente à direção do sentimento na reflexão sobre este objeto não podem alcançar nenhum conceito de beleza, pois que não distinguem absolutamente nada no conjunto da impressão sensível. Os outros, que tomam o entendimento como guia exclusivo, jamais podem alcançar um conceito de beleza, pois no todo nada veem além das partes, e espírito e matéria aparecemlhes eternamente separados, mesmo em sua unidade mais perfeita", e acrescenta, "Evitaremos os dois escolhos em que ambos naufragaram, se começarmos pelos dois elementos em que a beleza se divide diante do entendimento, e depois nos elevarmos à pura unidade estética mediante a qual ela atua sobre a sensibilidade e na qual esses dois estados desaparecem inteiramente" (SCHILLER, 2002, p. 93-94).

${ }^{142}$ A alusão à cultura grega antiga como cultura modelar é procedimento já utilizado em escritos anteriores e bastante recorrente nas Cartas. Na Carta VI, Schiller escreve: "Numa observação mais atenta do caráter do tempo, entretanto, admirar-nos-emos do contraste que existe entre a forma atual da humanidade e a passada, especialmente a grega. A glória do aperfeiçoamento (Ausbildung) e do refinamento, que fazemos valer, com direito, contra qualquer outra mera natureza, não nos pode servir contra a natureza grega, que desposou todos os encantos da arte e toda a dignidade da sabedoria sem tornar-se, como a nossa, vítima dos mesmos. Não é apenas por uma simplicidade, estranha a nosso tempo, que os gregos nos humilham; são também nossos rivais, e frequentemente nossos modelos (...)" (SCHILLER, 2002, p. 35. Trad. modificada).Em O fragmento e a síntese, Silva (2003, p. 45) sustenta que o retorno de Schiller ao mundo grego antigo tem por objetivo fornecer à época moderna um modelo de cultura da totalidade à qual o homem possa se comparar, mas também seguir. Neste sentido, Silva afirma: "O primeiro (o mundo grego) comprova haver constituído uma cultura da totalidade, pela forma como os avanços da razão especuladora harmonizando-se com uma natureza feita de cosmos, deuses e homens. Se a razão unifica e a cultura especializa, os gregos só fizeram coordenar uma instância com a outra ligando saber e arte, fazendo a erudição conforme aos costumes e às crenças na idealidade do homem pleno, culto, total (SILVA, 2003, p. 45-46).

${ }^{143}$ A correspondência mantida entre Schiller e Christian Gottfried Körner, teórico da arte e amigo de Schiller, durante a última década do século XVIII, revelam o processo de gestação e desenvolvimento da teoria da beleza schilleriana, marcada em grande medida pelo confronto com os pressupostos estéticos correntes:de um lado o subjetivismo empírico inglês, de modo particular o de Edmund Burke (17291797); de outro, pelo racionalismo objetivo da escola de Leibniz Wolff, especialmente o de Baumgarten (1718-1777) e de seus discípulos.Com Kant, Schiller buscará demonstrar a insuficiência destas escolas no que diz respeito à fundamentação do juízo estético. Contra Kant, Schiller afirmará a possibilidade de se demonstrar um fundamento objetivo para o belo. Tais reflexões tinham como objetivo as preleções de estéticas do semestre de inverno de 1792-93, que foram publicadas por um de seus alunos um ano após a morte de Schiller sob o título Fragmentos das preleções sobre estética de Schiller no semestre de inverno de 1792-93.
} 
determinada pela objetividade do medium, a matéria (ex: o mármore da escultura) e tampouco pela subjetividade ou pelo gosto peculiar do artista. O primeiro caso resulta na apresentação "rígida" e "pesada" do fenômeno, numa palavra, "feia"; no segundo, uma apresentação "amaneirada". Schiller escreve: "Se num desenho há um único traço que torna reconhecíveis a pena ou o lápis, o papel ou a chapa de cobre, o pincel ou a mão que o realizou, então ele é rígido ou pesado; se nele é visível o gosto peculiar do artista, então é amaneirado" (SCHILLER, 2002, p. 114). Em ambos os casos, afirma Schiller, a heteronômica, uma interferência exterior, faz-se presente na apresentação, o que significa dizer que a natureza do representado sofre violência ou do medium ou do artista, jamais pode se apresentar livremente. Na referida carta à Körner, Schiller escreve:

Livre seria pois a apresentação se a natureza do médium aparecesse inteiramente aniquilada pela natureza do imitado, se o imitado afirmasse sua personalidade pura também no seu representante, se o representador, através de uma completa renúncia ou, antes, através de uma renegação de sua natureza, parecesse tê-la trocado completamente com o representado - em suma - se nada existisse pelo material e sim tudo pela forma(SCHILLER, 2002, p. 114).

Caracterizar o estilo como suprema independência da apresentação é entender o belo artístico como uma "imitação" livre de determinações exteriores, enquanto afirma aquilo que Schiller designa como a "autodeterminação" (Selbst-selbstbestimmung) de sua forma, ou seja, dar livre curso a sua natureza (em sentido estético) ${ }^{144}$. O conceito schilleriano de estilo, certamente influenciado pelo ensaio de Goethe (Imitação simples da natureza, maneira, estilo), revela-se como o princípio objetivo e normativo da bela arte: "Pura objetividade da apresentação é a essência do bom estilo: o princípio supremo das artes" (SCHILLER, 2002, p. 114).

\footnotetext{
${ }^{144} \mathrm{O}$ conceito schilleriano de natureza deve ser compreendido numa acepção estética. Numa carta a Körner de 23 de fevereiro de 1793, Schiller escreve: "O que seria pois natureza nesta acepção? O princípio interno da existência numa coisa, considerado ao mesmo tempo como fundamento de sua forma; a necessidade interna da forma. A forma tem de ser ao mesmo tempo autodeterminada $\mathrm{e}$ autodeterminante no sentido mais próprio; tem de haver aí não mera autonomia, e sim autoautodeterminação" (Selbst-selbstbestimmung). A auto-autodeterminação da forma, portanto, consiste na sua liberdade própria para a atualização de sua necessidade interna, o que significa dizer a livre manifestação de sua natureza. Em introdução à tradução brasileira da correspondência entre Schiller e Körner entre janeiro e fevereiro de 1793, Barbosa (2002, p.24) explica que a Selbst-selbstbestimmung, termo que traduz por "heautonomia", consiste numa "propriedade rigorosamente objetiva, já que subsiste no objeto mesmo quando abstraímos do sujeito, mas não se confunde com um 'em si', uma vez que é subjetivamente mediatizada".
} 
O grande artista, afirma Schiller, é o que apresenta o objeto puro, pois a apresentação tem objetividade pura; o medíocre mostra a si mesmo, a própria natureza, uma vez que sua apresentação sofre a interferência da subjetividade; e o mau artista, por fim, mostra a matéria, pois a apresentação pessoal é determinada pela natureza do medium e pela limitada capacidade técnica. Em outros termos, bom é o artista que opera em conformidade com a "forma", isto é, com a natureza (estética) do objeto, ao superar ao mesmo tempo a natureza da matéria, o medium, e a natureza do artista, a maneira, ao produzir o estilo, princípio supremo da arte e condição da beleza: "Beleza", afirma Schiller, "não é pois outra coisa senão liberdade no fenômeno" (SCHILLER, 2002, p. 60). Contudo tal liberdade não é total, mas domada pela natureza do objeto, ou seja, pela regra que este impõe a si mesmo. Em suma, a condição da beleza é a não determinação do exterior e a liberdade para seguir sua própria determinação. É neste por isso que se deve entender a beleza como "natureza na conformidade à arte" (SCHILLER, 2002, p. 85).

Pura objetividade na aparência, o estilo é o princípio e a condição da arte bela. Ora, se a beleza se refere ao objeto "livremente apresentado", de acordo com o princípio do estilo, então se afirma que o belo na beleza artística, seu princípio formal e objetivo, é o estilo. Schiller apresenta uma relação de reciprocidade entre os conceitos de estilo e de belo. Associado ao conceito de belo, o conceito schilleriano de estilo revela sua face estética, ao conceito de liberdade, sua face ética. Mas como pensar esta pura objetividade do estilo? Em outras palavras, se a beleza é um juízo estético e a liberdade, um juízo moral, como conceber a beleza como liberdade no fenômeno, e, portanto, livre da subjetividade? Esta questão conduz ao âmago da teoria schilleriana do belo, ao demarcar o ponto de sua ruptura com a estética de Kant.

É manifesto que a Crítica da faculdade do juízo de Kant, publicada em 1790, é o ponto de partida para a teoria da beleza de Schiller ${ }^{145}$. Porém, contra a asserção kantiana acerca da impossibilidade de se deduzir, a partir do juízo de gosto, um princípio objetivo para o belo ${ }^{146}$ - o que implica a validade universal e necessária, bem como a

\footnotetext{
${ }^{145}$ Em uma carta de 5 de março de 1791, pouco depois da publicação da terceira crítica kantiana, Schiller escreve a Körner: "Você não adivinha o que leio e estudo agora? Nada menos do que Kant. Sua Crítica da faculdade do juízo, que adquiri, me estimula através do seu conteúdo pleno de luz e rico em espírito, e me trouxe o maior desejo de me familiarizar aos poucos com sua filosofia" (SCHILLER, 1874, p. 402-3. Trad. Ricardo Barbosa).

${ }^{146}$ No início do $\S 17$ da Crítica da faculdade do juízo, intitulado Do ideal de beleza, Kant argumenta sobre a impossibilidade de se estabelecer um critério objetivo para o gosto. O filósofo escreve: "Não pode haver nenhuma regra de gosto objetiva que determine através de conceitos o que seja belo. Pois todo juízo proveniente dessa fonte é estético; isto é, o sentimento do sujeito, e não o conceito de um objeto, é seu
} 
imanência deste princípio ao objeto (coisa-em-si) -, Schiller admite a possibilidade de dedução deste princípio, não via razão, o que implicaria necessariamente uma apreensão subjetiva, mas da objetividade da obra de arte.

Dado que a representação do belo prescinde de $\operatorname{conceitos}^{147}$, a beleza, para Schiller, não se encontra nos domínios da razão teórica, ao necessitar, portanto, de buscar no âmbito da razão prática ${ }^{148}$. Diferente da razão teórica, que aplica forma a representações, podem ser estas, conceitos ou intuições, a razão prática aplica forma a ações, que são ações livres (ações morais) ou não-livres (efeitos naturais). As ações livres ou autodeterminadas são as ações produzidas de acordo com a forma da razão prática, o que significa, da vontade pura, faculdade de autodeterminação: "pois uma vontade pura e a forma da razão prática são a mesma coisa" (SCHILLER, 2002, p. 58). Por serem livres e autodeterminadas, são morais. Desse modo, quando a razão aplica sua forma a uma ação moral, "ela exige imperativamente que seja pela forma pura da razão" (SCHILLER, 2002, p. 58). Mas se a razão aplica sua forma a uma ação que não for produzida pela vontade pura, por exemplo, a um efeito natural, então empresta "ao objeto (regulativamente, e não constitutivamente, como no ajuizamento moral) uma faculdade de determinar a si mesmo, uma vontade, e o considera em seguida sob a forma dessa vontade dele (e não dela, pois senão o juízo tornar-se-ia um juízo moral)"(SCHILLER, 2002, p. 58). Dessa forma, a razão pode afirmar acerca do objeto

fundamento determinante. Procurar um princípio do gosto, que forneça o critério universal do belo através de conceitos determinados, é um esforço infrutífero, porque o que é procurado é impossível e em si mesmo contraditório. A comunicabilidade universal da sensação (da complacência ou descomplacência), e na verdade uma tal que ocorra sem conceito, a unanimidade, o quanto possível, de todos os tempos e povos com respeito a este sentimento na representação de certos objetos, é o critério empírico, se bem que fraco e suficiente apenas para a suposição da derivação de um gosto, tão confirmado por exemplos, do profundamente oculto fundamento comum (gemeinschaftlichen) a todos os homens, da unanimidade no ajuizamento das formas sob as quais lhes são dados objetos" (KANT, I. Fundamentação da metafísica dos costumes. Trad. Valerio Rohden e António Marques. Rio de Janeiro: Forense Universitária, 1993, p. 77).

147 No $\$ 6$ da Crítica da faculdade do juízo,Kant escreve: “O belo é o que é representado sem conceitos como objeto de uma complacência universal” (KANT, 1995, p. 56). Sobre esta asserção kantiana, numa carta de 8 de fevereiro de 1793, Schiller escreve a Körner: "Pois bem, Kant está manifestamente correto ao dizer que o belo apraz sem conceito; posso já ter achado belo um belo objeto muito antes simplesmente de ser capaz de indicar a unidade do seu múltiplo e de determinar o que é a força dominante no mesmo" (SCHILLER, 2002, p. 54). Tomar o belo como uma representação sem conceitos implica na impossibilidade dessa representação ser apreendida pela razão teórica, pois esta não pode aplicar sua forma a representações que não estejam em conformidade com ela mesma.

${ }^{148} \mathrm{Na}$ carta de 8 de fevereiro de 1873, dirigida a Körner, Schiller escreve: "Suponho que você se surpreenderá por não encontrar a beleza sob a rubrica da razão teórica e que isso o deixará bastante inquieto. Mas não posso sequer lhe socorrer; ela certamente não se encontra na razão teórica, pois é simplesmente independente de conceitos; e como tem de ser seguramente procurada na família da razão, e além da razão teórica não existe outra senão a prática, teremos então de procurá-la e também encontrála justo aqui. E penso também que você deve, ao menos no que se segue, se convencer de que esse parentesco não a desonra" (SCHILLER, 2002, p. 57). 
(ação) se ele é por si mesmo, ou nos termos de Schiller, "se ele é aquilo que é por sua vontade pura, ou seja, pela sua força autodeterminadora" (SCHILLER, 2002, p. 58), pois a forma da razão prática é a "autodeterminação pura".

Destarte, a autodeterminação pura na ação de um ser racional advém da razão pura, pois o seu si mesmo é a razão; a autodeterminação pura de um ser natural advém da natureza pura, "pois o si mesmo do ser natural é a natureza" (SCHILLER, 2002, p. 59). Quando a razão prática, aplicada a um ser natural, constata que ele é determinado por si mesmo, por sua própria natureza, então ela the atribui o que Schiller designa de "similaridade à liberdade (Freiheitsähnlichkeit) ou, numa palavra, liberdade" (SCHILLER, 2002, p. 59). Contudo, dado que esta liberdade é emprestada pela razão ao objeto natural, ou seja, que o objeto apareça como liberdade sem que efetivamente seja livre, "então essa analogia de um objeto com a forma da razão prática não é liberdade de fato, e sim meramente liberdade no fenômeno, autonomia no fenômeno"(SCHILLER, 2002, p. 59).

Para Schiller, um ajuizamento de ações não-livres como, por exemplo, os efeitos naturais segundo a forma da razão prática, é um ajuizamento estético. A analogia entre o fenômeno e a forma da vontade pura ou da liberdade é a beleza. A seguir, a definição de beleza como "liberdade no fenômeno". Mas se a liberdade é acrescida pelo pensamento ao objeto natural, então Schiller ainda permanece no campo da subjetividade. É preciso doravante investigar o que, no objeto, proporciona-lhe a possibilidade de aparecer como livre e autodeterminado ao apresentar, contra Kant, um princípio objetivo para o belo ${ }^{149}$. Em suma, é preciso demonstrar o que torna possível que a liberdade no fenômeno, a beleza, seja necessária e universal, logo assentida por todos. Para tanto, afirma Schiller, "é exigido que o objeto mesmo nos convide, ou antes nos obrigue a notar nele a qualidade de não-ser-determinado-do-exterior (das Nichtvonaußensbestimmtsein)" (SCHILLER, 2002, p. 83), isto é, a qualidade de ser livre de determinações alheias, em que se obriga a produzir no homem essa ideia de liberdade e a referi-la ao objeto.

A qualidade de não-ser-determinado-do-exterior do objeto, portanto, sua liberdade, lhe é conferida de forma negativa pela razão. Todo objeto é determinado ou

\footnotetext{
${ }^{149}$ Esta é a objeção colocada por Körner à definição de beleza proposta por Schiller na carta de 8 de fevereiro de 1793. Na carta de resposta a Schiller, datada de 15 de fevereiro do mesmo ano, Körner argumenta: "Seu princípio de beleza é meramente subjetivo; ele se baseia na autonomia, a qual é acrescentada em pensamento ao fenômeno dado. Pois bem, é de se perguntar se não é possível conhecer nos objetos as condições sobre as quais se baseia esse acrescentar em pensamento a autonomia" (SCHILLER, 2002, p. 62).
} 
do exterior, ou do não exterior, o que significa dizer do interior ${ }^{150}$. O entendimento é a faculdade que busca o determinante para o determinado; o fundamento para a consequência, ao aplicar sua forma ao objeto e verificar se a forma do objeto está em conformidade com a forma do pensamento ${ }^{151}$. A forma de um objeto indica que este existe a partir de uma regra, de uma determinação, e, segundo Schiller, "Uma forma que indica uma regra (que se deixa tratar por uma regra) chama-se conforme à arte ou técnica" (SCHILLER, 2002, p. 84).

Num ajuizamento lógico, promovido pelo entendimento, a técnica deve ser conhecida e a correlação formal entre o objeto e o pensamento deve ser necessária. A forma de um relógio, por exemplo, indica sua determinação uma vez que é possível reconhecer nele a técnica que lhe foi dada pela própria razão. Porém, quando o ajuizamento é estético, isto é, quando se aplica a formas naturais, o entendimento não exige que a técnica seja conhecida. No caso de não conhecer a técnica, o entendimento não se deduz a determinação exterior, assim, não pensado como originado do exterior, este objeto aparece como, do interior, ou seja, determinado por si mesmo e por isso objetivamente livre: “"Assim pois que o ser-determinado (das Bestimmtsein) é pensado, o não-ser-determinado-do-exterior é indiretamente, ao mesmo tempo, a representação do ser-determinado-do-interior (des Voninnenbestimmtsein) ou da liberdade"" (SCHILLER, 2002, p. 82-83).

Ora, ainda que a forma do objeto estético provoque o entendimento a buscar sua determinação, esta deve ser negada ao conhecimento. Schiller escreve:

Uma regra, um fim, nunca podem aparecer, pois eles são conceitos e não intuições. O fundamento real da possibilidade do objeto nunca se dá nos sentidos, e ele é tão bom quanto não existente, 'tão logo o entendimento não é levado à procura do mesmo' (...) Portanto, uma forma aparece como livre tão logo não encontramos seu fundamento fora dela nem sejamos levados a procurá-lo fora dela (SCHILLER, 2002, p. 70).

Dessa mameira, a condição para a representação da liberdade no fenômeno e, portanto, do estilo, é o não conhecimento da técnica. Em outras palavras, é necessário que a regra permaneça para o entendimento sempre oculta e indeterminada, pois se a técnica for conhecida, o objeto deixa de ser livre e, portanto, belo. "Bela, explica

\footnotetext{
${ }^{150}$ Cf. Schiller, 2002, p. 83.

${ }^{151}$ Cf. Schiller, 2002, p. 83.
} 
Schiller, é uma forma que não exige nenhuma explicação ou também que se explica sem conceito" (SCHILLER, 2002, p. 70); como se a técnica, ou a arte, estivesse em plena conformidade com a sua natureza própria, isto é, com o seu si mesmo. Quanto mais a técnica do objeto for captável pelo entendimento, mais determinado do exterior e menos livre ele será. Destarte, afirma Schiller, "A liberdade no fenômeno é, a saber, o fundamento da beleza, mas a técnica é a condição da nossa representação da liberdade" (SCHILLER, 2002, p. 85).

Em conformidade com a técnica que dá a si mesmo, o objeto se mostra livre para atualizar sua natureza (estética) e tornar-se o que ele é. Dado isso, a definição de beleza proposta por Schiller: "Beleza é natureza na conformidade à arte (...) Natureza na conformidade à arte é o que dá a regra a si mesmo - o que é através de sua própria regra. (Liberdade na regra, regra na liberdade)" (SCHILLER, 2002, p. 85). Assim, a beleza diz respeito à conformidade entre a natureza do objeto, isto é, "a necessidade interna da forma" (SCHILLER, 2002, p. 90) e sua matéria, o seu conteúdo. No caso dos objetos naturais, estes aparecem como corpos dotados de massa e de movimento próprios. Porém, a beleza, afirma Schiller, só é percebida “onde a massa é inteiramente dominada pela forma" (SCHILLER, 2002, p. 87) e pelo movimento: "Se a massa teve influência sobre a forma, então esta é chamada de maciça; se a massa teve influência sobre o movimento, então este se chama desajeitado" (SCHILLER, 2002, p. 87). Desse jeito, quanto maior for a influência da massa, de sua força gravitacional, sobre a sua forma ou sobre o movimento, menos belo ele será, pois menos livre se apresenta:

Tão $\operatorname{logo}$ a gravidade atue sobre uma coisa, por si mesma e independentemente da propriedade específica dessa coisa, apenas como força natural universal, então ela é vista como uma violência estranha e seus efeitos comportam-se como heteronômica diante da natureza da coisa (SCHILLER, 2002, p. 86).

A representação do belo, portanto, ocorre onde a relação entre a forma e a massa do objeto apareça equilibrada, onde não ocorra nenhuma violência ou heteronômica por parte de sua massa, o que o privaria da liberdade. Nesta acepção, um pássaro aparece mais belo do que um touro na medida em que aparece mais livre e menos condicionado pela matéria ${ }^{152}$. Em suma, julga-se mais belo o objeto quanto mais este apareça para o

${ }^{152}$ À guisa de exemplificação, Schiller escreve: "Entre os gêneros animais, a linhagem dos pássaros é a melhor prova do meu princípio. Um pássaro em vôo é a mais feliz apresentação da matéria subjugada 
indivíduo como autodeterminado. Schiller escreve: “o conteúdo, por sublime e amplo que seja, atua sempre como limitação sobre o espírito, e somente da forma pode-se esperar verdadeira liberdade estética (...) O verdadeiro segredo do mestre, portanto, é este: pela forma, ele destrói sua matéria” (SCHILLER, 2002, p. 111-112).

Embora a autodeterminação (Selbst-selbstbestimmung) se mostre como uma propriedade objetiva, uma vez que subsiste no objeto independente de sua relação com o sujeito, não se toma como um "em si”, posto que ele é, através da técnica, subjetivamente mediatizado pela razão. Nos termos de Schiller: "O fundamento da liberdade adjudicada ao objeto encontra-se pois nele mesmo, embora a liberdade se encontre apenas na razão" (SCHILLER, 2002, p. 91). A beleza, para Schiller, consiste numa síntese das determinações objetiva e subjetiva, a objetividade da técnica e a subjetividade da razão que representa a liberdade.

No tocante à obra de arte, a sua plena conformidade com a natureza é o que Schiller designa por estilo. Livre de determinações exteriores da natureza e da maneira, o estilo é pura objetividade da apresentação, o que possibilita que a liberdade apareça no fenômeno. Doravante, este conceito passa a ser um imperativo para a obra de arte que anseie pela beleza objetiva e seu assentimento universal. Desse modo, quanto mais determinada por si mesma, quanto mais próxima de sua natureza própria, mais bela a arte será. É por este motivo, afirma Schiller, que o ingênuo é belo, "porque aí a natureza afirma seus direitos sobre a artificialidade e o fingimento" (SCHILLER, 2002, p. 99).

No entanto, a ingenuidade como expressão artística é uma qualidade possível apenas ao artista ingênuo, o que significa dizer, ao gênio. Em Poesia ingênua $e$ sentimental (1800), Schiller afirma: "Todo verdadeiro gênio tem de ser ingênuo, ou não é gênio. Apenas sua ingenuidade o torna gênio (...)” (SCHILLER, 1991, p. 51). Assim, as características principais do gênio consistem na naturalidade e na ingenuidade, bem como na espontaneidade: "Em primeiro lugar, é de todo necessário que o objeto que o inspira seja natureza ou ao menos assim considerado por nós; em segundo lugar, que seja (no significado mais amplo da palavra) ingênuo, isto é, que a natureza esteja em contraste com a arte e a envergonhe" (SCHILLER, 1991, p. 43).

pela forma, da gravidade superada pela força. Não é sem importância observar que a capacidade de vencer a gravidade é frequentemente usada como símbolo da liberdade. Expressamos a liberdade da fantasia enquanto lhe damos asas; deixamos Psiche erguer-se com asas de borboleta sobre o plano terreno quando queremos designar sua liberdade dos grilhões da matéria. A força da gravidade é manifestamente um grilhão para todo o orgânico, e uma vitória sobre a mesma não oferece, pois, nenhum símbolo inadequado da liberdade" (SCHILLER, 2002, p. 88). 
Uma arte verdadeiramente bela é uma arte regida pelas leis formais da harmonia, como se mostra no estilo simples e ingênuo dos antigos em que o conteúdo é inteiramente subsumido pela forma. Por aparecer ao espectador como uma totalidade, isto é, como indeterminada, a arte verdadeiramente bela pode oferecer uma contemplação livre das determinações do entendimento e dos sentidos, assim, afirma Schiller: "Se nos entregarmos, entretanto, à fruição da beleza autêntica, somos senhores, a um tempo e em grau idêntico, de nossas forças passivas e ativas, e com igual facilidade nos voltaremos para a seriedade e para o jogo (...) para o pensamento abstrato ou para a intuição" (SCHILLER, 2002, p. 93-94). É, portanto, na fruição da arte verdadeiramente bela que se pode superar a dicotomia entre pensamento e intuição; entre interioridade e exterioridade e, por conseguinte, entre indivíduo e Estado. Em $A$ educação estética do homem Schiller institui a beleza como princípio fundamental do que chamou de Estado estético (Äestelischer Staat):

Se já a necessidade constrange o homem à sociedade e a razão nele implanta princípios sociais, é somente a beleza que pode dar-lhe um caráter sociável. Somente o gosto permite harmonia da sociedade, pois institui harmonia no indivíduo. Todas as outras formas de representação dividem o homem, pois fundamse exclusivamente na parte sensível ou na parte espiritual; somente a representação bela faz dele um todo, porque suas duas naturezas têm de estar de acordo (SCHILLER, 2002, p. 144145).

Contra a violência imposta por um Estado racional, que constrange o homem à sociedade, Schiller propõe um Estado estético fundado na educação estética do indivíduo, pois na fruição da arte bela o indivíduo deixa de ser fragmento e se forma como o todo do Estado.

Schiller acredita que na experiência estética com a beleza o homem possa se realizar como homem pleno, por este motivo aposta numa educação estética do homem como possibilidade de construção de um homem total, que ultrapasse a condição de indivíduo e ascenda ao sujeito moral, livre das inclinações individuais. Na Carta XXIII, o poeta conclui ser esta uma tarefa da cultura (Kultur):

É das tarefas mais importantes da cultura, pois, submeter o homem à forma ainda em sua vida meramente física e torná-lo estético até onde possa alcançar o reino da beleza, pois o estado moral pode nascer apenas do estético, e nunca do físico. Se o 
homem deve possuir, em cada caso particular, a faculdade de tornar sua vontade e seu juízo o juízo da espécie; se deve encontrar a passagem de cada existência limitada para uma existência infinita; se deve poder elevar-se de todo estado dependente para a espontaneidade e liberdade, é preciso prover para que em nenhum momento ele seja somente indivíduo e sirva apenas a lei natural. Se deve ser capaz e estar pronto para elevar-se do círculo estreito dos fins naturais para os fins da razão, ele há de ter se exercitado para os fins da razão já nos primeiros e há de ter realizado já sua determinação física com uma certa liberdade de espírito, isto é, segundo as leis da beleza (SCHILLER, 2002, p. 115).

A partir do criticismo kantiano, Schiller constata a origem da barbárie na fragmentação da totalidade do homem. Se na antiguidade grega a natureza humana gozava de uma plena harmonia entre suas faculdades especulativas e intuitivas, no homem moderno se instalou uma oposição radical entre essas duas faculdades. Por priorizar a ilustração da sabedoria em detrimento da evolução da sensibilidade, o homem moderno se constituiu de modo unilateral e fragmentado. A superação da dicotomia entre o entendimento e a sensibilidade e, consequentemente, dessa condição de bárbaro, só é possível a partir de uma nova concepção de formação do homem, o que significa uma formação que tenha como princípio a educação estética do indivíduo a partir da fruição da obra de arte autenticamente bela, simples e ingênua, numa palavra, com estilo.

\section{$* * *$}

Procurou-se mostrar de que modo o pensamento de Winckelmann, Goethe e Schiller constitui um legado precioso para o jovem Nietzsche na medida em que é a partir destas matrizes que o filósofo alemão pensará a relação entre o estilo e formação e, por conseguinte, entenderá a barbárie alemã do século XIX como ausência de educação estética do homem. Embora Winckelmann não tenha formulado um conceito preciso de estilo, tampouco desenvolvido uma teoria estético-pedagógica minuciosa a partir de sua intuição acerca da formação do gosto, sua concepção estético-ética de estilo será fundamental para uma ulterior elaboração desses elementos no contexto do classicismo alemão que se segue. Neste ambiente teórico, Goethe é o primeiro a dar ao conceito de estilo um sentido preciso e um lugar central no pensamento estético do século XVIII, seja no âmbito de sua reflexão sobre a produção artística, como expõe o 
ensaio Imitação simples da natureza, maneira, estilo, seja como base para elaboração de sua proposta de formação a partir da educação estética do homem, conforme apresentada no romance Os anos de aprendizado de Wilhelm Meister. Dessa maneira, o conceito goethiano de estilo retomará de Winckelmann a acepção ao mesmo tempo ética e estética quando influência de forma decisiva o pensamento de Schiller que passará a formular, a partir da teoria do belo ideal ou do estilo goethiano, uma teoria da educação estética do homem como condição para a superação da barbárie. Guardadas as diferenças entre os dois autores, as considerações de Goethe e Schiller sobre o tema da barbárie parecem incidir sobre a mesma causa: a falta de educação estética do homem. Dessa forma, cada um ao seu modo procurou demonstrar que a superação da barbárie e, consequentemente, a formação do homem, bem como a realização da cultura total de um povo não dependem da ilustração do homem e do desenvolvimento das suas potencialidades racionais. Pelo contrário, na medida em que fortalece o sentimento da interioridade e o exercício da subjetividade, a manutenção deste tipo de formação só obterá como fim a barbárie. Com Winckelmann, Goethe e Schiller, Nietzsche associará a barbárie alemã ao desenvolvimento da interioridade (Innerlichkeit) do alemão e, tal como os mestres, buscará na concepção de educação estética do homem um possível caminho para a superação da barbárie alemã. 


\section{CAPÍTULO 3 \\ O ESTILO E A EDUCAÇÃO ESTÉTICA DO HOMEM NO \\ JOVEM NIETZSCHE}

Da formação trágica à formação retórica

Se Nietzsche constata a falta de unidade de estilo e, portanto, a barbárie em seu tempo, foi porque, enquanto segue a trilha aberta por Winckelmann, Goethe e Schiller, tomou a cultura grega antiga como modelo de formação (Bildung) e cultura (Kultur). Ao associar a barbárie alemã à falta de educação estética (aesthetische Erziehung), o jovem Nietzsche, tal como os seus mestres, tomará a arte como o princípio fundamental da formação. Contudo, num primeiro momento, no contexto de $O$ nascimento da tragédia e de $A$ visão dionisíaca do mundo, ele se afastará de seus mestres em dois pontos essenciais. Primeiramente, a Grécia que o filósofo alemão considera como modelo para a formação não é a clássica, mas sim a da época trágica, pré-socrática, cuja característica não é a serenojovialidade, mas o pessimismo.

Não obstante, após $O$ nascimento da tragédia, Nietzsche fará uma segunda incursão pelo mundo Grego, porém desta vez o filósofo não tomará a arte trágica como instrumento de educação estética dos helenos, mas sim a arte retórica. Esta mudança de perspectiva, que ocorre entre os anos de 1872 e 1875, é designada por alguns comentadores pela expressão "giro retórico"153. Se de um lado este movimento indica o afastamento de Nietzsche dos motivos românticos do primeiro livro, sobretudo da ideia wagneriana de fundação de uma nova mitologia e da "metafísica de artista" de procedência schopenhaueriana, por outro lado, revela uma nova maneira de abordar o fenômeno da linguagem, que já não é mais entendida como uma ilusão apolínea forjada a partir da música, mas como arte retórica.

Dessarte, o escopo deste capítulo consiste em apresentar uma concepção estético-ética de estilo em Nietzsche, desde sua primeira versão integrada à "metafísica de artista" de procedência schopenhaueriana, até a sua virada retórica fundamentada pela sua crítica da linguagem. Com isso, pretende-se mostrar de que modo o jovem Nietzsche pensou o vínculo entre estilo e formação através da tragédia e da arte retórica, instrumentos de educação estética do homem grego. Compreender esta relação no

${ }^{153}$ Cf. Casares, 2002, p.07. 
pensamento juvenil de Nietzsche se faz necessário na medida em que está na base dos ataques nietzschianos contra a pseudoformação alemã de sua época, bem como em sua avaliação do estilo na filosofia.

Se o classicismo alemão tomou a nobre simplicidade e a grandeza serena ${ }^{154}$ como princípios éticos e estéticos que fizeram do estilo artístico dos gregos um instrumento de formação foi porque, para Nietzsche, eles não compreenderam o verdadeiro sentido da tragédia ática ${ }^{155}$. Da perspectiva trágica, a cultura grega não pode ser reduzida aos ideais de "serenojovialidade" (Heiterkeit) ${ }^{156}$ e "simplicidade" (Simplicität), haja vista que o sentido mais profundo desta arte é o"pessimismo" (Pessimismus) ${ }^{157}$ e o "antagonismo" (Gegensatz). Na afirmação da conjuntura terrível

\footnotetext{
${ }^{154}$ Em Geschichte der Kunst des Alternhums, Winckelmann caracteriza a cultura clássica grega como dotada de uma nobre simplicidade e uma grandeza serena(edle Einfalt und stille Größe) tanto na atitude quanto na expressão (Cf. Winckelmann, J.J. Reflexões sobre arte antiga. Trad. Herbert Caro e Leonardo Tochtrop. Estudo introdutório de Gerd Bornheim. Porto Alegre: Movimento, 1975, p. 53-4). Esta interpretação influenciará tanto o classicismo quanto o romantismo no que diz respeito à concepção de que características essenciais da cultura grega são a simplicidade e serenidade, o que faz dela uma cultura eminentemente apolínea.

${ }^{155}$ Segundo Meca (2011, p.25), o motivo do descontentamento de Nietzsche em relação às interpretações classicistas e românticas, reside no fato de que nem o classicismo nem o romantismo foram capazes de determinar o real significado de expressões como "volta aos gregos", "imitação da cultura grega", "renascimento na Alemanha de uma nova Grécia". Tais expressões, na acepção nietzschiana, só seriam compreendidas à luz de uma visão integral da cultura grega, o que depende, em última análise, de uma compreensão mais profunda da tragédia ática. Meca escreve: "[...] De modo que, por 'volta aos gregos' haveria que entender um trabalho de revisão e de reatualização (Vergegenwärtigung) capaz de sobreporse ao esquecimento do trágico que não é algo acidental, isto é, que não é devido a ignorância nem ao descuido, mas que é algo constitutivo de e consubstancial ao mais próprio e essencial da modernidade (como assinalou bem mais tarde o pensamento de Heidegger)".

156 Acompanhamos aqui a decisão de J. Guinsburg que, em sua tradução para o português de $O$ nascimento da tragédia(Companhia das Letras, 1992),visando resgatar a amplitude semântica do termoalemão Heiterkeit, optou por um acoplamento de dois dos principais sentidos do termo, a serenidade e a jovialidade.

157 Segundo Machado (2005), a procura por um princípio constitutivo do mundo grego diferente da serenojovialidade não é uma invenção nietzschiana. Tal procura, afirma o autor, teve início com o idealismo absoluto do final do séc XVIII, particularmente com Schelling, que realiza pela primeira vez uma interpretação ontológica de uma tragédia grega de modo a construir uma visão trágica do mundo. Doravante, este modo de proceder se torna constante não só entre os idealistas alemães, mas em toda interpretação ontológica da tragédia grega. O autor escreve: "É assim, por exemplo, que a primeira interpretação ontológica de uma tragédia grega — a que Schelling dá, em 1795, de Édipo rei — se baseia na oposição e na reconciliação da liberdade e da necessidade. É assim também que a interpretação hegeliana de Antígona é feita a partir da oposição entre a família e o Estado. É ainda assim que Hölderlin interpreta Édipo e Antígona a partir da oposição entre a composição orgânica representada pela sobriedade e o tumulto aórgico originário" (MACHADO, 2005, p. 177). Para maior compreensão acerca da interpretação ontológica da arte trágica grega, Cf. MACHADO, R. Nietzsche e o renascimento do trágico. Kriterion, Belo Horizonte, nº 112, p. 174-182, Dez/2005.
} 
da existência, expressa na sabedoria de Sileno ${ }^{158}$, o pessimismo grego se revela como uma manifestação de saúde e vitalidade desse povo. Sua origem, segundo Nietzsche, encontra-se no impulso artístico mais profundo da cultura helênica, o dionisíaco. Num póstumo da década de 1870, Nietzsche escreve: "O dionisíaco como mãe do mistério, da tragédia, do pessimismo (Pessimismus)" (Nachlass/FP 1870, 9 [60], KSA 7.297). Filho do dionisíaco, o pessimismo é um sentimento mais primordial do que a serenojovialidade, pois é a partir dele que ela se torna possível. Em $O$ nascimento da tragédia, Nietzsche escreve:

[...] as luminosas aparições dos heróis de Sófocles, em suma, o apolíneo da máscara, são produtos necessários de um olhar no que há de mais íntimo e horroroso na natureza, como que manchas luminosas para curar a vista ferida pela noite medonha. Só neste sentido devemos acreditar que compreendemos corretamente o sério e importante conceito da 'serenojovialidade grega' [griechischen Heiterkeit]; ao passo que, na realidade, em todos os caminhos e sendas do presente, encontramo-nos com o conceito falsamente entendido dessa serenojovialidade, como se fosse um bem-estar não ameaçado (GT/NT § 9, KSA, 1.64)

A serenojovialidade grega, desta perspectiva, não é entendida como um sentimento primordial e tampouco constante, como pensaram os clássicos alemães, mas secundário e passageiro, pois é apenas o efeito da ilusão apolínea que, por algum tempo, inibe o horror dionisíaco. Desse modo, a serenojovialidade é relacionada ao mundo da aparência (Schein), mais especificamente com o "mecanismo (Mechanismus) do apolíneo e do dionisíaco" (Nachlass/FP 1870, 6 [15], KSA 7.134).

Em A visão dionisíaca do mundo, escrito preparatório para $O$ nascimento da tragédia, este mecanismo se expressa como um antagonismo estilístico sobre o qual os gregos construíram sua arte trágica. Dessa maneira, as divindades gregas Apolo e Dioniso são apresentadas por Nietzsche como a dupla fonte de toda produção artística helênica, isto é, como nomes que representam estilos artísticos antagônicos, mas que, uma vez unidos, produziram a tragédia ática ao elevar a arte a um nível jamais visto. $\mathrm{O}$ filósofo escreve:

${ }^{158} \mathrm{Cf}$. GT/NT § 3, KSA, 1.34. 
Os gregos, que em seus deuses nos dizem as doutrinas secretas de sua visão do mundo e a mantém ao mesmo tempo em silêncio, apresentaram duas divindades, Apolo e Dioniso, como a fonte dupla de sua arte. Estes nomes representam estilos antagônicos [Stilgegensätze] no âmbito da arte, os quais, quase sempre em luta entre eles, vão caminhando um ao lado do outro e só uma vez, no momento de floração da "vontade"[Wille] helênica, se manifestam fusionados para produzir a obra de arte da tragédia ática (DW/VD $\S 1$, KSA, 1.553, Trad. J.B.L. modificada).

Estilos artísticos primordiais e antagônicos de toda produção artística grega, os deuses Apolo e Dioniso surgem, "sem a mediação do artista humano" (GT/NT § 2, KSA, 1.30), como princípios estéticos ideais designados a simbolizar os dois estados (Zuständen) em que, segundo Nietzsche, "o ser humano alcança a sensação deliciosa da existência" (DW/VD $\S 1$, KSA, 1.553, Trad. J.B.L. modificada): o sonho (Traum) e a embriaguez (Rausch). Assim, a vontade ${ }^{159}$ ora surge como "bela aparência onírica" (schöne Schein der Traumwelt) na figura de Apolo; ora como embriaguez na figura do deus Dioniso; e, por fim, uma vez mais como fusão entre os estilos anteriores na ideia trágica (tragische Idee).

Para Nietzsche, tais ideais artísticos são necessários na medida em que o homem necessita da ilusão e da aparência como meio de se esquivar à consciência de miserável condição expressa na sabedoria de Sileno. No jogo $(\text { Spiel })^{160}$ com a arte, o homem se

\footnotetext{
${ }^{159} \mathrm{O}$ conceito de vontade (Wille) utilizado pelo jovem Nietzsche remonta à metafísica schopenhaueriana. Sobre a noção de vontade em Schopenhauer, cf. nota 73.

$160 \mathrm{O}$ conceito de jogo é introduzido na estética alemã moderna a partir das reflexões de Kant, de modo particular, da sua Crítica da faculdade do juízo, em que o filósofo de Königsberg descreve a experiência estética do belo como consequência do "jogo das faculdades" do entendimento e imaginação, diferentemente da experiência do sublime, em que não há jogo, mas uma ocupação séria da imaginação.No $\$ 23$ da terceira crítica kantiana, lê-se: "A última complacência (Kant refere-se aqui à satisfação estética do sublime) também se distingue muito da primeira quanto à espécie: enquanto o belo comporta diretamente um sentimento de promoção da vida, e por isso é vinculável a atrativos e a uma faculdade de imaginação lúdica, o sentimento do sublime é um prazer que surge só indiretamente, ou seja, ele é produzido pelo sentimento de uma momentânea inibição das forças vitais e pela efusão imediatamente consecutiva e tanto mais forte das mesmas, por conseguinte enquanto comoção não parece ser nenhum jogo, mas seriedade na ocupação da faculdade da imaginação" (KANT, 1995, p. 90). A não seriedade do jogo e a concordância entre as faculdades do entendimento e da imaginação, portanto, é a condição da experiência do belo na medida em que liberta o objeto da apreensão da razão revelando uma finalidade puramente formal. A complacência do belo, a satisfação estética da beleza, desperta o sentimento de liberdade e totalidade no sujeito que se torna o mesmo com o objeto, no caso do sublime, é interditado por conceitos da razão. Assim, o jogo exprime a possibilidade da conciliação de faculdades que, sem ele, são inconciliáveis, permitindo ao homem o sentimento de totalidade.Duflo (1999) escreve:
} 
cura da dor e do sofrimento eternos de sua existência mais íntima ${ }^{161}$. Contudo, a arte em si já é também, um jogo. Como estilo artístico, Apolo nasce do "jogo do artista com o sonho"(DW/VD $\S 1, \mathrm{KSA}, 1.553$, Tad. J.B.L.), ao passo que Dioniso surge "do jogo com a embriaguez" (DW/VD $\S 1$, KSA, 1.553, Tad. J.B.L.). Compreendida como jogo, a vida e, por conseguinte, toda produção artística e experiência estética se encontra destituída de qualquer implicação subjetiva, já que quem joga não é o sujeito artista, mas a vontade. Em outros termos, quando o homem joga com a efetividade, quando artista joga com os sonhos ou com a embriaguez, não é o indivíduo quem joga, mas o único jogador que realmente existe: a vontade.

Jogo do homem com o efetivo (Wirkliche), o sonho se revela como uma capacidade inata ao homem de transfigurar a efetividade criando a partir dela a aparência (Schein) prazenteira. Neste jogo com o efetivo, cada ser humano é "um artista completo" (DW/VD $\S 1, K S A, 1.553)$. Assim que se submete efetividade à forma e à medida que o homem cria, em seus sonhos, as belas imagens oníricas que, em seguida, serão imediatamente compreendidas e apreciadas. Nietzsche escreve: "Nós gozamos na compreensão imediata da figura, todas as formas nos falam; não há nada indiferente e

\footnotetext{
"Há nisso a ideia profunda de que duas faculdades que, por sua distinção, poderiam marcar uma divisão no ser humano, verificam, na experiência estética, que se convêm mutuamente, atestando por meio do jogo, a unidade final do ser humano. O prazer é a reconciliação do ser inteiro, é a satisfação de ser uno" (DUFLO, 1999, p. 61).Na esteira da filosofia kantiana, o conceito de jogo aparece nas Cartas sobre a educação estética do homem de Schiller também como um meio para se pensar a unificação entre razão as faculdades que dividem o homem, visando assim sua constituição plena. Schiller escreve: "A razão, sobre fundamentos transcendentais, impõe a exigência: entre a tendência formal (Formtrieb) e a tendência material (Stofftrieb), deve haver uma comunhão (Gemeinschaft), isto é, uma tendência ao jogo (Spieltrieb), pois somente a unidade da realidade e da forma, da contingência e da necessidade, da passividade e da liberdade pode realizar o conceito de humanidade" (SCHILLER, apud, DUFLO, 1999, p. 73). A reciprocidade entre a razão e a sensibilidade é o que se deve sempre almejar quando se pensa na constituição do homem total. Sobre a noção schilleriana de "tendência ao jogo", Duflo (1999) explica: "Ela (a reciprocidade entre razão e sensibilidade) é o que está sempre a realizar. Enquanto tal, é uma Ideia no sentido kantiano, isto é, um conceito regulador e não constitutivo, mais a visar do que a encontrar, e essa Ideia nada mais é para o homem do que a Ideia de sua humanidade" (DUFLO, 1999, p. 73). O caráter lúdico da contemplação estética interdita a faculdade do entendimento e impede a razão de atuar conceitualmente. Assim, a satisfação estética do belo se mostra desinteressada, pois emancipa o sujeito dos interesses práticos da vida. Na acepção nietzschiana, o jogo é destituído de todo elemento subjetivo, na medida em que não se restringe a uma atividade lúdica entre faculdades do sujeito, mas sim numa atividade da Vontade com ela mesma. Nietzsche pensa no caráter lúdico da criança; no jogo no sentido heraclitiano do termo. Sobre a noção de jogo em Nietzsche Cf. FINK, E. Spiel als Weltsymbol. Stuttgart: Kohlhammer, 1960; BEHLER, E. Nietzsche und die romantische Metapher von der Kunst als Spiel, In: BATTS, M.S. et al. (orgs.). Echoes and influences of German Romanticism. Frankfurt/Meno: Peter Lang, 1987. GERVÓS, L.E.S. A dimensão estética do jogo na filosofia de F. Nietzsche. Cadernos Nietzsche. São Paulo, nº 28, p. 49-72, 2011.

${ }^{161}$ Num fragmento póstumo do final de 1870-abril de 1871, Nietzsche escreve: "A vontade tende à cura, aos gozos supremos isentos de dor. Para isso tem necessidade das representações ilusórias que como mecanismos enganadores se potencializam até a santificação e a obra de arte" (Nachlass/FP 18701871,7[100], KSA, 7.161).
} 
não necessário" (DW/VD $\S 1, K S A, 1.553)$. Não obstante, é possível que o sonhador confunda os limites entre a vivência aparente do sonho e a vivência efetiva da vigília, o que pode ter como consequência efeitos patológicos uma vez que os sonhos já não podem mais reconfortar o homem. Em meio a esse perigo, Apolo surge como o deus que salvaguarda, na obra de arte, os limites da aparência quando isenta o homem de tais efeitos nocivos.

Para Nietzsche, jogar com o sonho é uma característica humana, contudo só é dado ao artista o privilégio de produzir, a partir deste jogo, a obra de arte. Nietzsche escreve:

A estátua como bloco de mármore é uma coisa muito efetiva, mas o efetivo da estátua como figura onírica é a pessoa vivente do deus. Enquanto a estátua flutua ainda como imagem da fantasia ante os olhos do artista, este ainda joga com o efetivo: quando traduz essa imagem ao mármore, o artista joga com os sonhos" (DW/VD $\S 1, \mathrm{KSA}, 1.553$, trad. J.B.L. modificada).

Nietzsche compara o ato de produção do artista apolíneo ao ato de produção filosófica. Neste sentido, assim como o filósofo procede com a realidade aparente na qual se vive e se é, pressente-se que sob esta realidade existe outra, oculta, e que também é uma aparência. Do mesmo jeito procederá o artista apolíneo com a realidade dos sonhos quando interpreta a vida a partir da aparência onírica e, com base nela, produzirá uma nova aparência. Como deus da aparência, Apolo se caracteriza, segundo Nietzsche, “(...) com a esplêndida imagem divina do principium individuationis (princípio de individuação)" (GT/NT § 2, KSA, 1.30) ${ }^{162}$. Em outras palavras, ele é a representação artística do poder multiplicador do Uno-primordial (Ur-Einen ${ }^{163}$ que, por

\footnotetext{
${ }^{162}$ Nietzsche retoma o conceito de principium individuationis de Schopenhauer e o utiliza no mesmo sentido deste, ou seja, como o que possibilita singularizar e pluralizar, através do tempo e do espaço, a Vontadeessencialmente indivisa. No $\S 23$ de $O$ mundo como vontade e representação, Schopenhauer escreve: "Até a forma mais universal de toda representação, ser objeto para um sujeito, não lhe concerne, muito menos as formas subordinadas àquela e que têm sua expressão comum no princípio de razão, ao qual reconhecidamente pertencem o tempo e espaço, portanto também a pluralidade, que existe e é possível somente no tempo e no espaço. Neste sentido, servindo-me da antiga escolástica, denomino tempo e espaço pela expressão principium individuationis (...)" (SCHOPENHAUER, 2005, p. 171).

${ }^{163}$ Nietzsche utiliza a expressão schopenhaueriana "Uno-primordial" ora como correlato de "natureza", ora como um correlato do conceito schopenhaueriano de vontade. Tal como em Schopenhauer, o Unoprimordial nietzschiano consiste na unidade metafísica essencial e indivisa a partir da qual surge toda a multiplicidade dos fenômenos.
} 
se encontrar pleno de contradição,"necessita, para a sua constante redenção, também da visão extasiante, da aparência prazerosa (...)"(GT/NT § 4, KSA, 1.38). Para tanto, ele intui o gênio (Genius) ${ }^{164}$.

Nos escritos juvenis de Nietzsche, o gênio é compreendido como uma intuição necessária da vontade ou do Uno-primordial. Este, uma vez contraditório - vontade incessante que só encontra repouso na aparência (Schein) -, necessita intuir o gênio: o recurso que redime esta contradição primordial no mundo fenomênico. Em um póstumo de 1873, o jovem filólogo escreve: "Enquanto a contradição é a essência do Uno primordial, pode ser ao mesmo tempo dor suprema e prazer supremo: o submergir-se na aparência é um prazer supremo: quando a vontade permanece completamente no exterior. Isto consegue a vontade no gênio" (Nachlass/FP 1869 - 1874, 7[157], KSA 7.200). O gênio artístico, portanto, é a projeção pela qual o Uno-Primordial projeta suas representações e, assim, Apolo, como divindade artística, consiste numa representação do Uno-primordial (Vorstellung des Ur-Einen).

Como deus artístico, Apolo representa os limites do sonho e da bela aparência. Nietzsche escreve: "Em que sentido foi possível converter Apolo em deus artístico? Só enquanto é o deus das representações oníricas (Traumesvorstellungen)"(DW/VD $§ 1$, KSA, 1.553). Apolo é o "resplendente" (Scheinende); o deus do sol e da luz, portanto, da verdade, dos vaticínios e também da bela arte. A beleza, afirma Nietzsche, é o seu elemento $^{165}$. Apolo é identificado ao conceito schopenhaueriano de belo (Schön) que, em última instância, surge da negação da vontade e, por conseguinte, do sofrimento. No $\S 39$ de $O$ Mundo como Vontade e Representação, Schopenhauer descreve a experiência estética do belo nos seguintes termos:

Enquanto esse vir-ao-encontro da natureza e a significação e distinção de suas formas mediante as quais nos falam as Ideias nelas individualizadas for o que nos tira do conhecimento das meras relações que servem à vontade, pondo-nos no estado de contemplação estética, para assim nos elevar a puro sujeito do conhecer destituído de vontade, é simplesmente o belo que age sobre nós, e o sentimento aí despertado é o da beleza (SCHOPENHAUER, 2005, p. 273)

\footnotetext{
${ }^{164} \mathrm{O}$ conceito de gênio (Genius) atravessa todo o corpus nietzschiano, assumindo perspectivas distintas em cada fase de seu pensamento. Sobre o conceito de Genius nos textos de juventude, Cf. NASSER, Eduardo. O destino do gênio e o gênio enquanto destino: o problema do gênio no jovem Nietzsche. Cadernos Nietzsche. São Paulo,n.30, 287-302, 2012.

${ }^{165} \mathrm{Cf}$. DW/VD $\S 1$, KSA, 1.553.
} 
O belo, para Schopenhauer, consiste num estado de contemplação estética que emancipa temporariamente o indivíduo dos desígnios da vontade, ao livrá-lo momentaneamente do sofrimento. Nietzsche também conceberá o belo como um paliativo, um sentimento estético que leva o homem a esquecer as intenções da vontade. Em um fragmento póstumo do final de 1870-Abril de 1871, o filósofo escreve: “O que é o belo? - uma sensação de prazer que nos oculta as verdadeiras intenções que tem a vontade em um fenômeno (...) O belo é a negação do sofrimento, a verdadeira negação do sofrimento ou a aparente negação dele" (FP III 7[27], KSA, 7.143). Como ilusão prazenteira, a bela aparência impõe limites ao terrível caos da existência: "Não há superfície bela sem uma profundidade terrível” (FP III 7[91], KSA, 7.159). Segundo Nietzsche, "é na arte dórica que se imortalizou essa majestosa e rejeitadora atitude de Apolo" (GT/NT § 2, KSA, 1.30).

Como estilo artístico, portanto, Apolo surge entre os dóricos caracterizado pela clareza e simplicidade, pela mesura e pelo limite que salvaguarda o homem na bela aparência onírica ao isentá-lo da dor e do sofrimento da existência. Nietzsche escreve: "Apolo: essa moderada limitação, esse estar livre das agitações mais selvagens, essa sabedoria e calma do deus escultor. Seu olho deve ser 'solar' e tranquilo: ainda quando está enojado e olhe de mau humor, a solenidade e a bela aparência o recobre" (DW/VD $\S 1$, KSA, 1.553). Não obstante, a força para erguer sobre o fundo terrível do existir uma aparência clara e bela não é comum a todo artista, mas somente ao artista ingênuo (naiv).

Nietzsche retoma o conceito de ingênuo da teoria estética de Schiller ${ }^{166}$, que o emprega para designar o estilo simples e objetivo, destituído de toda maneira (Manier) e

\footnotetext{
${ }^{166} \mathrm{O}$ conceito de ingênuo (naïf) é tomado por Nietzsche do ensaio Poesia ingênua e sentimentalde Schiller. O conceito de ingênuo, para Schiller, está relacionado com a sua ideia de natureza. Tomando a arte poética como exemplo, uma poesia será ingênua se não guardar traços de sua técnica de execução, parecendo ter sido gerada pela natureza e não pelo homem. Contudo, é preciso demarcar esta aproximação bem como a distância entre a utilização deste conceito pelos dois autores. Enquanto a estética nietzschiana encontra seus subsídios teóricos na metafísica da vontade de Schopenhauer, entendendo a ingenuidade como característica principal do gênio apolíneo, o único artista capaz de redimir o eterno sofrimento da Vontade no eterno prazer da aparência, o ponto de partida de Schiller é a terceira crítica kantiana, em que, em oposição à poesia sentimental, produzida a partir da subjetividade do poeta, a poesia ingênua se encontra numa relação direta com a objetividade da natureza. No contexto de $O$ nascimento da tragédia, ao aproximar o seu conceito de apolíneo ao conceito schilleriano de ingênuo (naïf), Nietzsche faz a ressalva de que o ingênuo "não é de modo algum um estado tão simples, resultante de si mesmo, por assim dizer inevitável (...)" (GT/NT § 3, KSA 1.34), mas é o resultado de uma luta, é um estado artístico a ser conquistado pelo artista dotado de força plástica para criar uma visão de mundo suplantando outra. Sobre o conceito de ingênuo em Schiller, Cf. SCHILLER, F. Poesia ingênua e sentimental. Trad. Márcio Suzuki. São Paulo: Iluminuras, 1991.
} 
subjetividade; um produto do gênio cuja característica principal é a naturalidade (aproximação da natureza) e a espontaneidade com que realiza a sua obra. Contudo, embora identifique o estilo apolíneo ao estilo ingênuo, Nietzsche não pode acompanhar Schiller na sua acepção deste conceito, pois, para Nietzsche, o estilo ingênuo não advém da espontaneidade e da naturalidade do artista e de sua união com a natureza ${ }^{167}$, mas da luta do gênio contra as forças terríveis da natureza.

Foi do combate contra as terríveis imagens do mundo dos Titãs que Homero, o gênio ingênuo grego, ergueu o ingênuo e belo mundo dos deuses olímpicos ${ }^{168}$. Por conseguinte, toda a cultura olímpica (olympische Cultur) dos gregos, segundo Nietzsche, revela-se como uma cultura apolínea (apollinischen Cultur). Em $O$ nascimento da tragédia Nietzsche escreve:

Onde na arte nos encontramos com o 'ingênuo' [Naive], ali temos de reconhecer o efeito supremo da cultura apolínea: a qual sempre há de primeiro derrubar um reino de Titãs e matar monstros, e, graças a poderosas ficções enganosas e ilusões prazenteiras, há de haver conseguido triunfar sobre uma horrorosa profundidade na consideração do mundo e sobre uma capacidade de sofrimento de máxima susceptibilidade (GT/NT § $3, \mathrm{KSA}, 1.34)$.

Para Nietzsche, o estilo ingênuo emerge da luta contra o sofrimento e a dor, não a luta do indivíduo, mas da própria vontade que, inicialmente transfigurada no gênio, realiza uma segunda forma de transfiguração (Verklärung) ao impor a bela forma à terrível aparência da efetividade. Diante disso, a vontade atinge o seu propósito: contemplar-se a si mesma, ver a si mesma na esfera superior da aparência e da individuação. Eis que, para Nietzsche, a grandeza de Homero, o gênio ingênuo por excelência: “A 'ingenuidade' homérica só deve ser entendida como a vitória completa da ilusão apolínea: é uma ilusão semelhante a que a natureza emprega com tanta

\footnotetext{
${ }^{167}$ Sobre o conceito de natureza em Schiller, cf. nota 143.

${ }^{168}$ Estamos de acordo com a leitura de Pimenta quando este questiona: "A pergunta que se impõe é: como o grego enfrentou e ultrapassou essa moral popular pessimista? A resposta: redimindo a existência através de sua transfiguração épica e mitológica, isto é, lançando sobre os horrores do mundo o véu maravilhoso da arte e da religião de extração apolínea" (PIMENTA, 2007, p. 67). Sobre o estatuto do apolíneo em $O$ nascimento da tragédia de Nietzsche Cf. PIMENTA, Olímpio. Sobre O Nascimento da Tragédia. In: ALVES Jr., D.G.(Org.). Os destinos do trágico: arte, vida, pensamento. Belo Horizonte: Autêntica/FUMEC, 2007.
} 
frequência para a realização de seus propósitos” (GT/NT § 3, KSA, 1.34). Na contemplação da beleza dos deuses olímpicos de Homero, a Vontade vê a si mesma transfigurada e delimitada.

Dessarte, o culto às imagens apolíneas se exteriorizava não só na poesia épica de Homero, mas também no estatuário, na arquitetura e em todo o conjunto das artes plásticas dos gregos. Ao objetivar a exigência ética da moderação e, concomitantemente, a exigência estética da beleza, ideais que se tornavam visíveis no estilo simples e ingênuo de Apolo. Nietzsche escreve: "A moderação, posta como exigência, é possível somente ali onde a medida, o limite, são considerados conhecíveis. Para poder ater-se aos próprios limites é necessário conhecê-los: daí a advertência

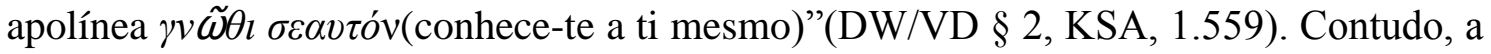
única visão que os gregos tinham de si mesmos, afirma Nietzsche, era a dos deuses olímpicos, que é a da bela aparência dos sonhos. Destarte, afirma o filósofo: "a moderação, sob cujo jugo se movia o novo mundo dos deuses (frente ao destruído mundo dos Titãs), era a moderação da beleza: o limite ao qual o grego havia de ater-se era o da bela aparência"(DW/VD $\S 2, \mathrm{KSA}, 1.559)$. Entendida assim, a perspectiva nietzschiana produz uma inversão da interpretação socrática do $\gamma \nu \tilde{\omega} \theta l \sigma \varepsilon \alpha v \tau \iota^{169}{ }^{169}$, uma vez que o conhecimento de si mesmo reside na experiência estética do belo e não na abstração dos conceitos filosóficos.

Enquanto o estilo apolíneo nasce do jogo do artista ingênuo com o sonho para se apresentar como a manifestação visível dos princípios ético da moderação e estético da beleza simples e ingênua, o estilo dionisíaco repousa no jogo do artista com a embriaguez e se apresenta como a subversão dos princípios constituintes do estilo apolíneo. Segundo Nietzsche, são dois os poderes que levam o ser humano ingênuo e natural ao auto-esquecimento e à embriaguez dionisíaca: o impulso da primavera e a bebida narcótica ${ }^{170}$. Sob o efeito desses poderes, o principium individuationis se esvai e,

\footnotetext{
${ }^{169}$ Discordamos da interpretação de Gentile (2010, p. 58) ao afirmar que, ao se referir ao $\gamma \nu \tilde{\omega} \theta l \sigma \varepsilon \alpha v \tau o ́ v$, Nietzsche teria sobrevalorizado o significado religioso da sentença e ignorado a interpretação filosófica feita por Sócrates. Defendemos que a menção à máxima délfica já traz consigo, ainda que de modo implícito, um posicionamento diante do cientificismo socrático na medida em que considera a máxima como um princípio para a formação estética e não filosófica do homem. Sobre a interpretação de Gentile, Cf. GENTILE, C. Os gregos aprenderam aos poucos a organizar o caos: os conceitos de estilo e cultura na Segunda consideração extemporânea deF. Nietzsche. Cadernos Nietzsche. São Paulo, n. ${ }^{\circ}$ 27, p. 51-71, 2010.

${ }^{170} \mathrm{Cf} . \mathrm{DW} / \mathrm{VD} \S 1, \mathrm{KSA}, 1.553$.
} 
com ele, toda delimitação moral e distinção social é dissolvida no Uno-primordial.

Nietzsche escreve:

\begin{abstract}
As festividades de Dioniso não só selam uma aliança de pessoa a pessoa, também reconciliam o ser humano com a natureza. De maneira voluntária oferece a terra seus dons, pacificamente se acercam os animais mais selvagens: panteras e tigres arrastam o carro de Dioniso, coroado de flores. Desaparecem todas as delimitações de casta que a necessidade e a arbitrariedade estabeleceu entre os homens: o escravo é homem livre, o nobre e o de baixo nascimento se unem para formar os mesmos coros báquicos. (DW/VD § 1, KSA, 1.553).
\end{abstract}

Segundo Nietzsche, a ruptura do principium individuationis dá acesso ao que há de mais íntimo no ser. Diferente da efetividade onírica, em que todo homem se mostra como completo artista, no jogo com a embriaguez o indivíduo deixa de ser artista e se torna ele mesmo, obra de arte produzida pelo modelador do universo: a Vontade. Agora, relaciona-se com a natureza "como a estatua com o artista apolíneo" (DW/VD § 1, KSA, 1.553). Assim, de um modo geral, o culto a Dioniso era caracterizado pela desenfreada licença sexual e pela dissolução de todos os vínculos sociais, o que constitui um pleno antagonismo frente a Apolo, deus da moderação ética e da beleza estética.

Como estilo artístico, Dioniso surge na Ásia e se expande por toda antiguidade. Para o homem grego apolíneo, a dança e a música entoada nos cultos dionisíacos era algo inaudito e até mesmo repulsivo. Os nómos ${ }^{171} \mathrm{e}$ os instrumentos da música

\footnotetext{
${ }^{171}$ Nos primórdios da música grega, nómos (lei) são pequenas fórmulas musicais que mais tarde originaram os modos ou escalas musicais. Eles são nómos justamente porque eram leis artísticas impostas pelo estado e, desrespeitá-los ou violá-los consistia uma infração contra o estado. Cada nomos corresponde a sua respectiva nacionalidade, conservando portanto o êthos (costumes; hábitos; normas) de seu lugar de origem (ex: dórico, Dória; frígio, Frígia etc.). Desse modo, no que tange o universo musical grego, podemos afirmar que há uma teoria do êthos que subjaz a teoria musical, uma vez que a música, para os gregos, tem o poder de despertar estados de ânimo no ouvinte e, por conseguinte, influenciar na sua formação e em suas ações. Tais estados de ânimo poderiam ser diversos, pois dependeriam da estrutura musical, ou seja, das combinações possíveis entre melodia, ritmo e poesia (melos, rhytmus, poiesis). Segundo Nasser (1997, p. 251-2), determinadas combinações, nómos musicais, poderiam induzir à ação, sendo que outras conduziriam ao estado de languidez e indolência; determinados nómos podem fortalecer o equilíbrio na alma do indivíduo, ao passo que outros poderiam enfraquecer a unidade da alma e o equilíbrio. 1) Ethos praktikón: induz à ação; 2) Ethikón: manifesta a força, o ânimo; a estes dois estados éticos estão relacionados os modos dórico e frígio (Cf. Rep. 399a); 3) Ethos malakón ou threnôdes: segundo Platão, este estado de espírito resulta dos cantos trenódicos baseados nas harmonias
} 
dionisíaca induziam o ouvinte a um estado de ânimo incompatível com o ethos ${ }^{172}$ apolíneo, caracterizado pela serenidade e constância expressas no nómos dórico quando entoado pela cítara e pela lira ${ }^{173}$.

Contudo, a despeito do radical antagonismo estilístico, Nietzsche afirma que o contato com a cultura apolínea grega faz com que Dioniso assuma novos contornos, como se, diante de Apolo, o deus selvagem fosse domesticado a ponto de tornar-se um aliado. O filósofo escreve: "Esta coexistência caracteriza o cume do helênico: originariamente só Apolo é um deus artístico na Grécia, e seu poder foi o que a Dioniso, que irrompia desde a Ásia, o moderou de tal medida que pode surgir a aliança fraterna mais formosa" (DW/VD $\S 1, \mathrm{KSA}, 1.553$ ). Assim, o que caracterizou o artista e a arte dionisíaca entre os gregos não foi a negação radical do estilo apolíneo, mas sim a coexistência destes dois estilos na música e na palavra. $\mathrm{O}$ primeiro fruto dessa união estilística foi o estilo lírico de Arquíloco.

Nietzsche criticará o posicionamento dos chamados "estetas mais recentes" (neueren Aesthetiker) acerca do conteúdo subjetivo da poesia lírica ${ }^{174}$, bem como sobre

plangentes (lastimosas) como lídia mista e a lídia tensa (Cf. Platão, Rep. 398e); 4) Ethos enthousiastikón: induz temporariamente à ausência de faculdades volitivas produzindo um estado de inconsciência. Esse ethos está associado aos ritos dionisíacos propícios à indução do êxtase e do delírio. Sobre o problema do ethos na música grega Cf. NASSER, N. A doutrina do ethos na música. Boletim do CPA, Campinas, n. ${ }^{\circ} 4$, p. 241-254, jul./dez. 1997.

${ }^{172}$ Nos referimos aqui a uma acepção do termo êthos (com epsílon inicial) que diz respeito ao costume, um comportamento que resulta de um constante repetir-se dos mesmos atos. É, portanto, o que ocorre com frequência ou muitas vezes (pollákis), mas não sempre (aế), nem em virtude de uma necessidade natural. Desta acepção provém a oposição entre éthei e physei, ou seja, o habitual e o natural. Nesta segunda acepção, podemos afirmar que o êthos representa uma constância no agir que se contrapõe ao impulso do desejo (órexis). É nesta acepção do termo, entendendo o êthos como disposição permanente que podemos encontrar as raízes semânticas que dá origem à significação do êthos como caráter, uma vez que a constância do seu modo de agir, seu hábito, será entendido como expressão de sua personalidade ética, daí a relação entre êthos como caráter e êthos como hábito (hexis). Sobre as acepções do termo, cf. VAZ, 1999, p.14; SPINELLI, 2009, p.10.

173 Os instrumentos utilizados pelos dóricos eram preferencialmente a cítara e a lira. As cítaras e liras mais antigas tinham de três a quatro cordas e, de acordo com sua afinação reproduziam somente as consonâncias fundamentais (4,5,8 justa), no canto produzia-se as sonoridades intermediárias. Associado à cítara e a lira está o nómos dórico (re/mi/fa/sol/la/si/do): austero, firme, capaz de manter o espírito firme diante das adversidades, e o frígio ( $\mathrm{mi} / \mathrm{fa} / \mathrm{sol} / \mathrm{la} / \mathrm{si} / \mathrm{do} / \mathrm{re}$.): capaz de conservar o caráter moral e também ser utilizada no canto de louvor aos deuses. Na República, Platão considera a cítara e a lira como os instrumentos ideais para expressa os hinos litúrgicos dedicados a Apolo. O timbre grave e majestoso desses instrumentos provoca no ouvinte um sentimento de ação e virilidade e, por isso, deveriam ser os instrumentos utilizados na formação dos guardiões da cidade ideal: "Resta-te a a lira e a cítara para se utilizarem na cidade (...) Certamente, meu amigo, que não fazemos nada de novo, ao preferirmos Apolo e os instrumentos de Apolo a Mársias". (Platão, Rep. 399e). Por outro lado, os modos lídios (fa/sol/la/si/do/re/mi) e mixolídio (sol/la/si/do/re/mi/fa) deveriam ser expulsos da cidade ideal, pois induzem à languidez e à preguiça. Sobre a relação entre a música e a educação em Platão, Cf. MOUTSOPOULOS, E. La musique dans l'ouvre de Platon. Paris: Presses Universitaires de France, 1959. 
a hipótese de que Arquíloco, "o belicoso servidor das musas" (kriegerischen Musendieners), o poeta da subjetividade, surge como oposição a Homero, o artista ingênuo (naiven Künstlers) e poeta da objetividade (Objectivität). Nietzsche afirma: "a estética mais recente soube apenas acrescentar interpretativamente que aqui, ao artista 'objetivo' (objectiven Künstler), se contrapõe o primeiro artista 'subjetivo' (subjectiven Künstler)" (GT/NT § 5, KSA, 1.42). Como expressão do sentimento (Empfindung) e subjetividade do poeta, a estética mais recente considerou o gênero lírico como plena oposição com a poesia ingênua, gênero ligado ao exterior e à objetividade da natureza $^{175}$. Na busca da superação dessa dialética entre subjetividade e objetividade, entre sujeito e natureza, Nietzsche encontrará na metafísica da vontade de Schopenhauer seu aporte teórico.

Para Nietzsche, a poesia lírica, enquanto expressão da subjetividade do artista, não pode ser tomada como atividade de um sujeito uno, idêntico a si mesmo e apartado do vir a $\operatorname{ser}^{176}$. De modo contrário, o sujeito, para Nietzsche, consiste já num modo de aparecer do Uno-primordial: “O 'eu’ do lírico (Ich des Lyrikers) soa portanto a partir do abismo do ser: sua 'subjetividade' (Subjectivität), no sentido dos estetas modernos, é uma ilusão (Einbildung)" (GT/NT § 5, KSA, 1.42). Dito de outro modo, o "eu” da poesia lírica é interpretado por Nietzsche como mera aparência, isto é, como transfiguração do Uno-primordial num aparente "sujeito" que fala. Logo, o universo imagético da poesia lírica não revela outra coisa senão ele mesmo, pois, segundo Nietzsche, tais imagens são "tão-somente objetivações diversas de si próprio" (GT/NT $\S$ 5, KSA, 1.42), porém este "si próprio" já é uma ilusão. Enquanto se refere a Arquíloco, Nietzsche escreve: "Na verdade, Arquíloco, o homem apaixonadamente ardoroso, no amor e no ódio, é apenas uma visão do gênio, que já não é Arquíloco, porém o gênio

\footnotetext{
${ }^{174}$ Encontramos na estética de Hegel um exemplo deste posicionamento. Segundo Werle (2001, p. 179), o tema da poesia lírica, em Hegel, define-se pela dimensão subjetiva que se resume, em linhas gerais, na interioridade do poeta. Neste sentido, diferente de Nietzsche que pensa a origem da poesia lírica na música, Hegel pensará esta origem na poesia épica a partir de um gradativo processo de autonomização do cantor épico. Sobre as considerações hegelianas acerca do caráter subjetivo da poesia lírica, Werle escreve: "A lírica surge para os povos como a expressão do desenvolvimento privado interior, no horizonte de uma consolidação das relações civis ou burguesas, ou seja, é a exploração da Empfindung, do sentimento, que na Enciclopédia das ciências filosóficas situa-se entre a intuição e a representação. A dimensão subjetiva da lírica nasce essencialmente nesta nova atitude do ser humano, que se volta para o seu interior desde o âmbito de uma situação, por assim dizer, épica. A lírica grega originou-se, segundo Hegel, da épica, o cantor lírico é nela o cantor (Sänger) épico que se autonomizou, que se singularizou e 'domesticou' o mundo exterior" (WERLE, 2001, p. 179).

${ }^{175}$ A oposição entre objetividade e subjetividade no procedimento poético, segundo Goethe, foi o ponto de partida da querela entre clássicos e românticos. Cf. nota 139.

${ }^{176}$ Sobre a noção de sujeito em Nietzsche, Cf. NIEMEYER, 2014, p.533.
} 
universal, e exprime simbolicamente seu sofrimento primigênio naquele símile de homem Arquíloco (...)”(GT/NT § 5, KSA, 1.42).

Por conseguinte, o fundamento da poesia lírica, para Nietzsche, não está na subjetividade do artista, mas na música, a própria expressão da Vontade ${ }^{177}$. Na poesia lírica, portanto, Dioniso fala a linguagem de Apolo. Sobre esta segunda forma de transfiguração, a do gênio lírico, em $O$ nascimento da tragédia lê-se:

Em primeiro lugar, ele [o poeta lírico], como artista dionisíaco, tornou-se um só com o Uno-primordial, com sua dor e contradição, e desse Uno-primordial produz uma réplica que é a música, ainda quando, por outro lado, esta seja denominada com todo direito de uma repetição do mundo e de uma segunda moldagem do mesmo; mas agora esta música se faz visível novamente, sob o efeito apolíneo dos sonhos, como em uma imagem onírica do tipo metafórico (GT/NT § 5, KSA, 1.42)

No universo das imagens oníricas da poesia lírica, não é a subjetividade do poeta quem fala, mas é a própria Vontade; é Dioniso que se expressa através da linguagem simbólica de Apolo. À questão acerca de como ocorre esta segunda forma de transfiguração da música em linguagem, Nietzsche responde: "Manifesta-se como vontade, ao tomar a palavra no sentido schopenhaueriano, isto é, como antagônico ao estado de ânimo estético puramente contemplativo, isento de vontade" (GT/NT § 6, KSA, 1.48).

Deste modo, a poesia épica se revela como a imitação da bela aparência, ao passo que a lírica consiste na imitação da música. Entretanto, a ideia de imitação da música traz consigo a necessidade de sua limitação. Isolada, é a pura expressão da

\footnotetext{
${ }^{177}$ No que diz respeito à hipótese nietzschiana sobre o fundamento musical da poesia, além da doutrina de Schopenhauer, a intuição poética de Schiller parece ter tido grande influência.Em $O$ nascimento da tragédia, Nietzsche escreve: "Acerca do processo de seu poetar, Schiller ofereceu-nos alguma luz através de uma observação psicológica, que se afigurava a ele próprio inexplicável, mas não problemática; ele confessou efetivamente ter tido ante si e em si, como condição preparatória do ato de poetar, não uma série de imagens, com ordenada causalidade dos pensamentos, mas antes um estado de ânimo musical" (GT/NT § 5, KSA, 1.42). Esta passagem do texto nietzschiano faz alusão a uma carta de Schiller a Goethe de 18 de março de 1796, na qual o poeta escreve: "Os preparativos para um conjunto assim tão complicado, como é esse drama, põem o espírito num movimento realmente singular (...) Gostaria de saber como o senhor procedeu em casos assim. Comigo, no início a sensação não tem um objeto determinado e claro; este só se forma mais tarde. Precede uma certa predisposição musical, e só então segue-a a ideia poética" (GOETHE; SCHILLER, 2011, P. 62).
} 
desmesura e do ilimitado impulso dionisíaco, no entanto, quando ela entra em contato com Apolo recebe deste, o poder da transfiguração que, em última análise, significa a possibilidade de se apresentar como imagem e palavra. Neste sentido, não é a música quem necessita da palavra, mas ao contrário, é a palavra quem necessita da música. Nietzsche escreve: “Toda essa discussão se atém estritamente ao fato de que a lírica depende do espírito da música tanto quanto a música mesma, em sua completa ilimitação (Unumschränktheit), não precisa da imagem nem do conceito, mas que unicamente os suporta ao seu lado" (GT/NT § 6, KSA, 1.48).

Com o intuito de compreender a distinção estilística entre o épico-apolíneo e o dionisíaco, afirma Nietzsche, "basta que por uma vez se medite profundamente sobre a diferença linguística de cor, estrutura sintática e material léxico em Homero e Píndaro, para se captar o significado deste antagonismo (Gegensatzes)" (GT/NT § 6, KSA, 1.48). A hipótese nietzschiana acerca da origem antagônica do estilo lírico consiste no núcleo de suas reflexões estéticas sobre a finalidade da tragédia ática grega.

O problema a respeito da origem e finalidade do drama ático não é nietzschiano, tampouco podemos atribuir a Nietzsche a hipótese de que a tragédia ática se originou do ditirambo, gênero lírico coral. Tanto o problema quanto a hipótese já existem na tradição ao menos desde a Poética de Aristóteles ${ }^{178}$. Não obstante, contra a hipótese aristotélica sobre a finalidade ética do drama grego, bem como o valor que o estagirita atribui à ação e à trama em detrimento do elemento lírico do coro $^{179}$, Nietzsche

\footnotetext{
178 Na Poética de Aristóteles esta hipótese é enunciada nos seguintes termos: "Mas, nascida de um princípio improvisado (tanto a tragédia, como a comédia: a tragédia dos solistas do ditirambo; a comédia dos solistas dos cantos fálicos, composições estas ainda hoje estimadas em muitas de nossas cidades), [a tragédia] pouco a pouco foi evoluindo, à medida que se desenvolvia tudo quanto nela se manifestava" (Poética, 1449a). Não obstante, ainda que Aristóteles tenha afirmado que a tragédia se originou do ditirambo, isso não significa que o ditirambo seja pura e simplesmente a célula primordial do drama trágico.Na introdução à tradução portuguesa da Poética, Eudoro de Souza (2003, p. 53) afirma ser na atividade peculiar dos "solistas do ditirambo" que se deve procurar a origem do drama ático: "É, portanto, no 'entoar (exárchein) o ditirambo', atitude já não mais puramente lírica, nem ainda perfeitamente dramática, mas onde afluem e donde refluem virtualidades expressivas de um e de outro gênero - que devemos procurar a oculta origem da tragédia" (SOUZA, 2003, p. 53).

${ }^{179}$ Sobre a valorização da ação e a finalidade moral da tragédia, Aristóteles escreve: "Porém, o elemento mais importante é a trama dos fatos, pois a tragédia não é a imitação de homens, mas de ações e de vida, de felicidade [e infelicidade; mas, felicidade] ou infelicidade reside na ação, e a própria finalidade da vida é uma ação, não uma qualidade (...) Daqui se segue que, na tragédia, não agem as personagens para imitar caracteres, mas assumem caracteres para efetuar certas ações; por isso, as ações e o mito constituem a finalidade da tragédia, e a finalidade é de tudo o que mais importa" (Poética, 1450a).
} 
entenderá o coro não só como o princípio fundador da tragédia, mas como o elemento mais importante dessa arte ${ }^{180}$ cuja finalidade não é ética, mas puramente estética.

Nietzsche também refuta a hipótese posta por August-Wilhelm Schlegel em suas Preleções sobre arte dramática e literatura que vê no coro trágico a imagem do perfeito espectador ideal (idealischen Zuschauers). Se pensado em sua forma primordial, o coro em si, destituído de todo elemento cênico e dramático, não faz sentido que seja a imagem do espectador ideal, uma vez que seria o espectador de si mesmo; um espectador sem espetáculo, o que, segundo Nietzsche, consiste num conceito absurdo ${ }^{181}$. Mais coerente, para Nietzsche, é a hipótese schilleriana expressa no prefácio à Noiva de Messina, em que a função do coro é salvaguardar o caráter ideal e a liberdade poética da tragédia, quando o protege do realismo. Nietzsche escreve: “A introdução do coro é o passo decisivo com o que de maneira aberta e explícita se declara a guerra a todo naturalismo em arte" (GT/NT § 7, KSA, 1.52). Para Nietzsche, é o sentido da experiência estética que está em jogo. Preservar a arte do realismo grosseiro ao conservá-la no plano do ideal significa, portanto, preservar a própria finalidade dessa experiência: o seu poder de cura.

É da música entoada pelo coro trágico que, segundo Nietzsche, desprende-se todo o universo da bela aparência apolínea no drama: a cena, o ator, a palavra são transfigurações de Dioniso. Assim, a tragédia se apresenta como fruto do mesmo antagonismo estilístico presente na poesia lírica, porém agora numa escala definitivamente maior de uma obra de arte total. Nietzsche escreve:

[...] reconhecemos na tragédia um radical antagonismo estilístico [Stilgegensatz]: a linguagem, a cor, a mobilidade, a dinâmica do discurso se dividem na lírica dionisíaca do coro e, por outro lado, no apolíneo mundo onírico do cenário, como esferas de expressão completamente separadas (GT/NT § 7, KSA, 1.52).

Filha do antagonismo estilístico, a nova arte dos gregos já não representa simplesmente a bela aparência apolínea e tampouco da embriaguez dionisíaca, mas na

\footnotetext{
${ }^{180}$ Cf. GT/NT $\S 8$, KSA, 1.57.

${ }^{181} \mathrm{Cf}$. GT/NT $\S 7, \mathrm{KSA}, 1.52$.
} 
forma de uma fusão entre as duas se apresenta como um fenômeno completamente inaudito para o espectador.

$\mathrm{O}$ espelho claro em que o principium individuationis se expressa; o belo e estático mundo erguido no combate do gênio ingênuo contra a Vontade, agora dá lugar a um vertiginoso devir de imagens que, tocadas pelo ímpeto dionisíaco, surgem e sucumbem. Em relação à experiência estética do espectador da arte trágica, Nietzsche escreve:

\begin{abstract}
[...] baseando-nos nas experiências do ouvinte verdadeiramente estético, nos imaginamos nós mesmos tal como o artista trágico, que cria suas figuras como se fosse uma exuberante divindade da individuatio, e neste sentido dificilmente se poderia considerar suas obras como uma 'imitação da natureza', - e logo, no entanto, o seu imenso impulso dionisíaco engole todo esse mundo dos fenômenos, para deixar pressentir, por trás desse mundo e mediante a sua aniquilação, uma suprema alegria primordial artística no seio do Uno primordial (GT/NT $\S 22$, KSA, 1.140).
\end{abstract}

Diferente da ilusão estática provocada pelo estilo ingênuo apolíneo, e diferente da completa embriaguez e dissensão provocada pelo estilo dionisíaco, o estilo trágico proporciona ao ouvinte verdadeiramente estético a experiência artística do vir-a-ser. Nela, o mundo da aparência e da individuação apolínea chega ao limite e nega a si mesmo na decomposição dionisíaca de seus indivíduos. Frente ao vir-a-ser do drama trágico, o espectador sente o deleite estético da bela imagem do herói, mas sente ainda um prazer maior em seu ocaso. Diante disso, a experiência estética do estilo trágico jamais pode ser a experiência do belo, da negação da vontade, mas sim do sublime ${ }^{182}$ : “a contenção artística do horroroso" (DW/VD $\S 1, \mathrm{KSA}, 1.553)$. A experiência estética do sublime, para Nietzsche, é a experiência da afirmação da vida em seu vir-a-ser. Na quebra do feitiço da individuação, o espectador se torna um só consigo mesmo e com o Uno primordial, isento do risco de ser dilacerado nele, pois tudo não passa de um jogo. Eis o poder formador da tragédia e do estilo trágico, que foi gradativamente extirpado na medida em que a "cultura socrática"(sokratischen Cultur) suplantou a "cultura

182 Sobre o rebatimento dos conceitos de belo e sublime sobre os conceitos de Apolo e Dioniso, cf. NABAIS, 1997, p. 32-33. 
trágica" (tragische Cultur) dos gregos, momento em que o conhecimento teórico assume cada vez mais o lugar do mito na formação do homem.

A influência da cultura socrática sobre a arte, segundo Nietzsche, pode ser constatada na formação do stilo rappresentativo e do recitativo, os gêneros precursores da ópera moderna. Enquanto se antecipa uma crítica que fará a Wagner anos mais $\operatorname{tarde}^{183}$, Nietzsche critica o modo como em tais gêneros a música é suplantada pela palavra. Sobre o recitativo, Nietzsche escreve:

Ao ouvinte que deseja captar com nitidez a palavra sob o canto corresponde o cantor, pelo fato de falar mais do que cantar e de aguçar nesse semicanto a expressão patética da palavra: por meio desse aguçamento do pathos, ele facilita a compreensão da palavra e subjuga aquela metade da música ainda restante (GT/NT § 19, KSA, 1.120)

Com efeito, é esta preponderância da palavra sobre a música, é este modo de proferir um discurso semicantado que caracteriza o recitativo e que está na essência do stilo rappresentativo. No entanto, para Nietzsche, nada é mais equivocado do que entender este "novo estilo" (neue Stil) ${ }^{184}$ como o ressurgimento da música grega antiga.

Diferentemente do estilo trágico, que é o resultado da união feliz dos estilos Apolo e Dioniso, o novo estilo não é capaz de realizar uma plena fusão estilística. Nietzsche escreve: "O que será das sempiternas verdades do dionisíaco e do apolíneo numa tal mistura de estilos, como eu a expus na essência do stilo rappresentativo, onde a música é considerada como serva, a palavra do texto como senhor (...)" (GT/NT § 19, KSA, 1.120). Para Nietzsche, o "novo estilo" se ergue sob os mesmos princípios da cultura socrática ou alexandrina (alexandrinischen Cultur), uma vez que é fruto do homem teórico e do crítico, não do autêntico artista. O entendimento da palavra é uma exigência de ouvintes não musicais e, neste sentido, afirma Nietzsche, "a ópera é a

\footnotetext{
183 Sobre Wagner, Nietzsche afirma: "Nisso podemos tê-lo (Wagner) como inventor e inovador de primeira ordem - ele aumentou desmesuradamente a capacidade de expressão da música: ele é o Victor Hugo da música como linguagem. Sempre com o pressuposto de se ter válido que a música possa, em dadas circunstâncias, não ser música, porém linguagem, instrumento, ancilla dramatúrgica (criada da dramaturgia)" (WA/CW §8, KSA, 6.29).

${ }^{184} \mathrm{Cf}$. GT/NT $\S 19, \mathrm{KSA}, 1.120$.
} 
expressão do laicado na arte, que dita as suas leis com o otimismo serenojovial do homem teórico" (GT/NT § 19, KSA, 1.120).

Estilo e cultura estão, portanto, intimamente ligados na medida em que é o predomínio de um estilo ou de outro que definirá a característica essencial da cultura como apolínea, trágica ou alexandrina. Neste seguimento, como expressão do "novo estilo", a ópera moderna é aquilo que, segundo Nietzsche, mais caracteriza a cultura socrática: "Não se pode caracterizar de forma mais aguda o conteúdo íntimo dessa cultura socrática do que denominando-a cultura da ópera (Cultur der Oper)" (GT/NT $\S$ 19, KSA, 1.120). O mundo moderno, afirma Nietzsche: "está preso na rede da cultura alexandrina e reconhece como ideal o homem teórico, equipado com as mais altas forças cognitivas, que trabalha a serviço da ciência (...) Todos os nossos meios educativos (Erziehungsmittel) tem originariamente esse ideal em vista (GT/NT § 18, KSA, 1.115).

Embora Nietzsche considere que a finalidade da arte não consiste na melhoria e formação do homem ${ }^{185}$, não deixará de ver na tragédia grega um instrumento de formação a ser imitado pelos modernos. Desta forma, a música alemã representa, para Nietzsche, o ressurgimento do espírito dionisíaco, logo um remédio contra este tipo de formação teórica do homem. Nietzsche escreve:

Do fundo dionisíaco do espírito alemão alçou-se um poder que nada tem em comum com as condições primigênias da cultura socrática e que não é explicável nem desculpável, a partir dela, sendo antes sentido por esta como algo terrivelmente inexplicável, como algo prepotentemente hostil, a música alemã, tal como nos cumpre entendê-la sobretudo em seu poderoso curso solar, de Bach a Beethoven, de Beethoven a Wagner. O que poderá empreender, no melhor dos casos, o socratismo de nossos dias, cobiçoso de conhecimentos, com esse demônio

\footnotetext{
${ }^{185}$ Compreendida como jogo, a vida e, por conseguinte, toda produção artística e experiência estética se encontra destituída de qualquer implicação subjetiva, já que quem joga não é o indivíduo artista, mas a Vontade. Em outros termos, quando o homem joga com a efetividade, quando artista joga com os sonhos ou com a embriaguez, não é o indivíduo quem joga, mas o único jogador que realmente existe: a Vontade. Assim, filósofo alemão desconsidera a hipótese acerca da finalidade pedagógica da arte na medida em que, sendo a arte não um produto do sujeito, mas da Vontade ela independe "de qualquer conexão com a altitude intelectual ou a formação artística do indivíduo" (künstlerischen Bildung des Einzelnen) (GT/NT $\S 2, \mathrm{KSA}, 1.30)$. Segundo Nietzsche: “(...) a comédia da arte não é representada por nossa causa, para a melhoria e formação (Bildung), tampouco que somos efetivos criadores desse mundo da arte: mas devemos sim, por nós mesmos, aceitar que nós já somos, para o verdadeiro criador desse mundo, imagens e projeções artísticas, e que a nossa suprema dignidade temo-la no nosso significado de obras de arte pois só como fenômeno estético podem a existência e o mundo justificar-se eternamente (...)" (GT/NT §5, $\mathrm{KSA}, 1.42)$.
} 
surgido de profundezas inexauríveis? (GT/NT § 19, KSA, $1.120)$.

De Bach a Wagner, a história da música alemã consiste, para Nietzsche, num gradual despertar do espírito dionisíaco que agora se apresenta aos alemães de seu tempo como a própria alma alemã. Este despertar do espírito dionisíaco se revela como o início do estilo trágico, a obra de arte total de Wagner, novo paradigma para a cultura e a formação do homem alemão. Neste sentido, Nietzsche considera que a música alemã, de modo particular a wagneriana,

[...] é, em meio a toda a nossa cultura, o único espírito de fogo limpo, puro e purificador, a partir do qual, como na doutrina do grande Heráclito de Éfeso, se movem em dupla órbita circular todas as coisas: tudo o que chamamos agora de cultura, formação, civilização (Civilisation) terá algum dia de comparecer perante o infalível juiz Dioniso" (GT/NT § 19, KSA, 1.120).

Deste modo, embora Nietzsche incorpore a acepção estético-ética de estilo desenvolvida por Winckelmann e continuada por seus sucessores classicistas, na medida em que propõe a arte trágica como o paradigma estético grego, o filósofo se volta contra essa tradição. Ao retomar os motivos românticos de Wagner e Schopenhauer, Nietzsche encontra no estilo trágico, resultado da união entre o estilo apolíneo e o dionisíaco, o princípio da formação do homem grego. Não obstante, a partir de $O$ nascimento da tragédia a sua avaliação sobre os gregos sofre uma radical transformação. Tal movimento foi entendido por alguns comentadores como um "giro retórico".

Em Le détour (Nietzsche et la rhétorique), artigo publicado em 1971 para a Poétique, Lacoue-Labarthe identifica que, entre os anos de 1872 e 1875, houve uma mudança radical de perspectiva nos escritos nietzschianos, ao revelar, em última análise, o crescente interesse pela questão da retórica em detrimento de sua primeira teoria trágica da arte. O deslocamento das preocupações do filósofo alemão é evidenciado, segundo Lacoue-Labarthe, pelo decisivo abandono das fontes românticas, sobretudo as wagnerianas, que subsidiavam toda aquela "metafísica de artista" consumada em $O$ 
nascimento da tragédia ${ }^{186}$. Neste sentido, Nietzsche fará uma segunda incursão pela Grécia antiga, porém sua atenção já não está voltada para a música, mas para a língua. É na língua de um povo que se encontra o espírito deste povo, logo é o instrumento para formar o homem e edificação da cultura por excelência. Para Nietzsche, o interesse dos gregos pela a arte retórica não é fortuito.

Da perspectiva nietzschiana, assim como a tragédia grega foi o resultado de um longo processo de fusão entre os estilos apolíneo e dionisíaco, também a criação do belo discurso, entre os gregos, não foi casual, mas o resultado de um longo e meticuloso trabalho sobre a língua, empreendimento que culminou na arte da retórica. Nos extratos do curso sobre a história da eloquência grega, Nietzsche escreve:

A eloquência foi cultivada pelos gregos com um labor e uma constância sem equivalente em nenhum outro domínio; dedicam-lhe uma energia cujo símbolo pode ser a educação que Demóstenes se impôs a si mesmo; a devoção à oratória é o elemento mais tenaz da cultura grega, e persiste através de todo o declínio desta [...] Ninguém deve pensar que uma tal arte caiu do céu; os Gregos nisso trabalharam mais do que qualquer outro povo e mais que qualquer outra coisa [...] (extratos do curso sobre a história da eloquência grega, KGW II 4, Trad. T.C.).

Presente em todas as etapas da vida do grego, desde a educação do jovem até a formação do homem político, a arte retórica atesta a natureza estética da pedagogia dos helenos. Em nota ao seu Curso sobre a retórica, Nietzsche escreve: “A formação do homem antigo culminava habitualmente na retórica: é a mais elevada atividade intelectual do homem politicamente formado - um pensamento que nos é bem estranho!" (Curso de retórica §1, KGW II 4, Trad. T.C).

O retorno à antiga arte retórica e a constatação de seu valor no âmbito da paideia grega tem um sentido estratégico no pensamento juvenil de Nietzsche. Filólogo, mas irredutível diante do historicismo e do otimismo científico característicos da filologia de

\footnotetext{
${ }^{186}$ No entanto, estamos de acordo com a opinião de Manuel B. Casares (2002, p.10) de que LacoueLabarthe teria se precipitado em afirmar que, após a liquidação dos pressupostos metafísicos de sua tese sobre a tragédia grega, Nietzsche abandona de vez o tema da retórica para se dedicar a uma abordagem naturalista orientada por argumentos fisiológicos. Se assim for, afirma Casares (2002, p.14), o "giro retórico" limitar-se-ia apenas a uma manobra pontual realizada por Nietzsche na ocasião específica do abandono de suas teses e fontes românticas, ou, em termos coloquiais, uma "cartada" ocasional contra o romantismo, o que em nosso entender não procede.
} 
seu tempo, Nietzsche encontra na retórica antiga uma via alternativa para compreender a relação entre linguagem e verdade, entre estilo e formação. Nos extratos sobre a eloquência grega, o filósofo escreve:

A pretensão mais ilimitada de tudo poder, como oradores ou como estilistas, atravessa toda a Antiguidade, de uma maneira para nós incompreensível. Controlam "a opinião sobre as coisas" e assim o efeito das coisas sobre os homens, eis o que eles sabem. Claro que para isso é preciso que a própria humanidade tenha recebido uma educação retórica (Extratos do curso sobre a história da eloquência grega, KGW II 4, Trad. T.C.).

Como oradores ou estilistas, os gregos foram capazes de perceber os efeitos do discurso sobre o homem, desde que este fosse previamente educado na arte da retórica. Doravante, desenvolveram tal arte de maneira metódica e consciente com vistas afins de natureza moral e política. Quando retoma Diodoro, Nietzsche afirma o poder discursivo como o elemento que distingue os gregos dos bárbaros; que "põe os gregos acima dos outros povos e as pessoas cultivadas acima dos incultos", e ainda que é "graças à oratória que um indivíduo pode se tornar senhor de uma multidão" (Extratos do curso sobre a história da eloquência grega, KGW II 4, Trad. T.C.).

$\mathrm{Na}$ medida em que se dirige à intuição (Anschauung) e não ao intelecto, o discurso retórico determina o "efeito (Wirkung) das coisas sobre os homens": "o efeito", afirma Nietzsche, "não é a essência das coisas" (Curso de retórica §1, KGW II 4, Trad. T.C), mas sim o modo como elas "aparecem" ao auditório. À proporção que controla o modo como as coisas aparecem, o estilista ou orador é capaz de controlar também a opinião (doxa) dos homens sobre as coisas e, ao suplantar o caos das opiniões antagônicas com o seu ponto de vista, torna-se senhor de uma multidão. Não obstante, o poder de determinar o "efeito das coisas sobre os homens", bem como o de controlar a “opinião dos homens sobre as coisas" só foi possível devido à natureza retórica da linguagem. Em seu Curso de retórica, o jovem Nietzsche escreve:

Mas não é difícil provar, à luz clara do entendimento, que o que se chama 'retórica', para designar os meios de uma arte consciente, estava já em ato, como meios de uma arte inconsciente, na linguagem e no seu vir a ser, e mesmo que $a$ retórica é um aperfeiçoamento [Fortbildung] dos artifícios já presentes na linguagem (Curso de retórica $\$ 3, \mathrm{KGW}$ II 4, Trad. T.C). 
Tem-se, então, que a arte retórica, enquanto uma produção consciente de um estilista ou orador, ou seja, como utilização consciente dos meios artísticos da linguagem para fins persuasivos, está desde sempre presente na linguagem como uma arte inconsciente. Logo, a linguagem é desde a origem constitutivamente retórica, ou, nas palavras de Nietzsche: "Não existe de maneira nenhuma a 'naturalidade' não retórica da linguagem à qual se pudesse apelar: a linguagem ela mesma é o resultado de artes puramente retóricas" (Curso de retórica§3, KWG II 4).

O contato com História do materialismo de Friedrich Albert Lange, mas também com a rica tradição filológica e linguística de sua época ${ }^{187}$, influenciou de maneira decisiva a concepção de linguagem do jovem Nietzsche que, em oposição à sua metafísica de artista, bem como à tradição racionalista, pressupõe a linguagem como sendo derivada da intuição e não da razão. Contra a ideia de uma gênese intelectual da linguagem, Lange defende a tese de que o seu surgimento advém de um procedimento estético, o que o leva a afirmar a polêmica tese da linguagem como obra de arte.

Desde escritos póstumos de 1870 e 1871 que Nietzsche pensa a linguagem como um produto da intuição humana, o que parece depor contra a ideia de um "giro retórico" uma vez que antes de 1872 Nietzsche já se pensava a linguagem nesta acepção. Não obstante, nestes escritos o conceito nietzschiano de intuição se afasta do fenomenalismo subjetivo de Kant e Schopenhauer para se aproximar de um fenomenalismo objetivo na linha da filosofia do inconsciente de Hartmann ${ }^{188}$. Neste sentido, Nietzsche entende mundo fenomênico como o resultado de um mecanismo da vontade que se intui a si mesma, e não como derivado de juízos sintéticos a priori ou de um princípio de razão ${ }^{189}$ constitutivo do sujeito. Nietzsche escreve:

Tenho receio em deduzir espaço, tempo e causalidade da miserável consciência humana: pertencem à vontade. Trata-se de pressupostos para todo simbolismo dos fenômenos [Erscheinung]: o homem mesmo é agora um tal simbolismo, e o mesmo há de se dizer do Estado e da terra. Mas este simbolismo

\footnotetext{
${ }^{187}$ Guervós (2000, p. 16) divide as fontes nietzschianas em dois grupos: um ligado à tradição da filologia clássica, integrado por Richard Volkmann, A. Westermann, L. Spengel e F. Blass; o outro ligado à tradição filológico-lingüística, reunindo autores como G. Gerber, e, através dele, a lingüística e a filosofia da linguagem do século XIX, como Hartmann e Schelling. Igualmente relevante, nota Guervós, foram as leituras científicas do jovem filólogo, delas destacamos A natureza dos cometas (1871) de J.C.F. Zöllner. ${ }^{188}$ Seguimos aqui a leitura de Claudia Crawford em CRAWFORD, C. The beginnings of Nietzsche's theory of language. New York: de Gruyter, 1998, p. 160.

${ }^{189}$ Cf. SCHOPENHAUER, 2005, p. 235.
} 
não existe como algo incondicionado unicamente para o homem singular - (Nachlass/FP 1870 - 1871, 5[81], KSA 7.114).

Com efeito, Nietzsche eleva o princípio de razão schopenhaueriano a um princípio cósmico ao afirmar que é a própria vontade que, a partir de uma intuição de si mesma, engendra o espaço, o tempo e a causalidade, quando concebe assim a pluralidade dos fenômenos e o movimento como aparência (Schein): "Na vontade há pluralidade e movimento só através da representação: um ser eterno se converte mediante a representação em vir-a-ser (Werden), em vontade, isto é, o vir a ser, a vontade mesma como agente é uma aparência" (Nachlass/FP 1870 - 1871, 5[80], KSA 7. 112). Entre vontade e representação, Nietzsche insere a noção de aparência, enquanto destitui, assim, o fenômeno de seu caráter meramente subjetivo para restituí-lo como aparência objetiva. O mundo fenomênico, nesta perspectiva, não é um produto da consciência humana, mas sim o produto de uma intuição de si mesma da vontade. $\mathrm{O}$ filósofo afirma: "Deste modo, toda vontade chegou a ser aparência e se intui a si mesma" (Nachlass/FP 1870 - 1871, 7[204], KSA 7.216).

É nesta intuição primeira, neste mecanismo que engendra representações, que a vontade, cuja essência é dor e sofrimento, encontra calmaria e êxtase. Dentre esta multiplicidade de aparências prazenteiras está o homem. Num póstumo redigido entre os anos de 1870 e 1871, Nietzsche escreve: "Só existe a vontade única: o homem é uma representação que nasce a cada momento" (Nachlass/FP 1870 - 1871, 7[125], KSA 7.181). Enquanto aparência gerada da Vontade, o homem se encontra numa condição ambígua: "Nós somos, por um lado, intuição pura (isto é, imagens projetadas de uma essência puramente extática, que encontra uma calma suprema nesta intuição), por outro lado, nós somos a mesma essência única” (Nachlass/FP 1870 - 1871, 7[201], KSA 7.214). Como a intuição pura, o indivíduo se encontra isento do sofrimento e da dor primordial, contudo, uma vez que se é um só com a vontade, participa também deste estado primordial:

(...) $\mathrm{Se}$ nos sentimos como a essência única, somos imediatamente elevados à esfera da intuição pura, a qual está completamente privada de dor: ainda que somos ao mesmo tempo a vontade pura, o sofrimento puro. Mas enquanto nós mesmos não somos mais que "o representado", não participamos deste estado sem dor: pelo contrário, o que representa desfruta completamente deste estado (Nachlass/FP 1870 - 1871, 7[201], KSA 7.214). 
Se por um lado o homem é o "representado", por outro, na medida em que participa da dor e do sofrimento primordial, é também "o que representa". Ora, assim como a Vontade busca na intuição, na projeção de imagens, o êxtase, o cessar da dor primordial, o homem também encontra na sua intuição o êxtase. É na produção artística que a intuição humana se efetiva: "Na arte, pelo contrário, nós chegamos a ser 'sujeitos que representam': daí o êxtase" (Nachlass/FP 1870 - 1871, 7[201], KSA 7.214).

Tal como o homem, a intuição humana, segundo Nietzsche, é apenas uma imagem projetada da intuição primeira da vontade. Nietzsche escreve: "Não obstante, parece que nossa intuição seja só a cópia da intuição única, isto é, nada mais que uma visão da representação única produzida em cada momento" (Nachlass/FP 1870 - 1871, 7[175],KSA 7.208). Mas a despeito de ser cópia da intuição da vontade, diferentemente dela, que gera imagens a partir de si mesma, o processo de representação no homem se inicia na sua relação com as coisas, isto é, na percepção de outras aparências da vontade.

O fato de que no homem a atividade de representar se inicia com a percepção de coisas não implica em reduzir a intuição humana a uma sensibilidade passiva. "A sensação (Empfindung)", explica o filósofo "não é um resultado da célula, mas a célula é um resultado da sensação, isto é, uma projeção artística, uma imagem. O substancial é a sensação, o aparente é o corpo, a matéria. A intuição tem suas raízes na sensação" (Nachlass/FP 1870 - 1871, 7[168], KSA 7.203). Próximo de Lange, Nietzsche entende a intuição humana como uma operação ativa de síntese da multiplicidade percebida, cujo resultado são unidades de aparências ou imagens psíquicas unitárias ${ }^{190}$, o símbolo (Symbol). Corpo e matéria são, portanto, símbolos.

Num póstumo redigido entre os anos de 1870 e 1871, o filósofo afirma: “A representação no sentimento tem só, no que diz respeito ao verdadeiro movimento da vontade, o significado de símbolo. Este símbolo é a imagem ilusória através da qual um instinto universal exercita um estímulo subjetivo individual" (Nachlass/FP 1870 - 1871, 5[80], KSA 7.112). Assim, o que se conhece, isto é, aquilo que afeta os sentidos, não é a essência das coisas, a coisa em si, mas somente representações a partir da qual se inicia o procedimento de criação simbólica, que consiste, em última análise, em produzir uma imagem da imagem. Em um póstumo de 1872, Nietzsche escreve:

${ }^{190}$ Cf. Crawford, 1998, p. 160. 
Inferências inconscientes me põem a pensar: isto é, sem dúvida, um processo de se passar de imagem para imagem. A imagem que é atingida por último opera como um estímulo e motivação. O pensamento inconsciente deve assumir um lugar separado do conceito: deve, portanto, ocorrer em intuições [Anschauungen] (Nietzsche apud Crawford, 1998, p.160).

A primeira imagem, portanto, consiste na multiplicidade de aparências da vontade que afeta o homem de modo inconsciente. Um primeiro pensamento inconsciente "deve, portanto, ocorrer em intuições". Enquanto o pensamento consciente só ocorre ulteriormente, como uma segunda imagem, ou seja, quando se começa a operar a partir dos símbolos da linguagem. Tornar-se consciente, neste sentido, significa recordar e relacionar símbolos. Nietzsche escreve:

O que significa chegar a ser consciente de um movimento da vontade? É um simbolismo que chega a ser cada vez mais claro. A linguagem, a palavra não são mais que símbolos. $\mathrm{O}$ pensamento, isto é, a representação consciente não é mais que a atualização e a relação dos símbolos linguísticos [...] o pensamento é recordação de símbolos (Nachlass/FP 1870 1871, 5[80], KSA 7.112).

Contra a ideia de uma gênese intelectual da linguagem, Nietzsche defende a hipótese de que o seu surgimento advém de um procedimento estético inconsciente, o que o leva a afirmar a polêmica tese da linguagem como arte. Enquanto arte, a linguagem não pode ter sido originada senão da intuição humana, um processo de criação simbólica que tem início na percepção humana da multiplicidade de aparências da vontade.

Além de Lange, a leitura de Die Sprache als Kunst de G. Gerber ${ }^{191}$ foi decisiva para a compreensão da origem artística da linguagem. Em Sobre verdade e mentira no

\footnotetext{
${ }^{191}$ Dentre as fontes citadas,Die Sprache als Kunst, obra de Gustav Gerber publicada em dois volumes entre 1872 e 1873, merece lugar de destaque, primeiramente, por ser uma das referências capitais na ocasião da preparação do Curso de retórica de Nietzsche, e, além disso, afirma Guervós, por se tratar de um sério "estudo da natureza e dos procedimentos artísticos da linguagem, que recorre e interpreta as categorias da retórica antiga a partir da ideia da origem retórica e poética da linguagem" (GUERVÓS, 2002, p.17). Gerber foi diretor do Realgymnasium em Bromberg. Em setembro de 1872, Nietzsche toma emprestado da biblioteca da Universidade da Basiléia o primeiro volume da referida obra, sendo muito provável que não chegou a ler o segundo volume. Sobre a influência de Gerber na teoria da linguagem do jovem Nietzsche cf. F. Nietzsche, Escritos sobre retórica, trad. Luis Enrique de Santiago Guervós. Madrid: Ed. Trotta, 2000; Bierl y William M. Calder III, "F. Nietzsche: 'Abriss der Geschichte der Beredsamkeit’. A new Edition”, em Nietzsche-Studien, 21 (1992), pp. 361-389; A. Meijers y Martin Stingelin, "Konkordanz zu den wörtlichen Abschriften und Übernahmen von Beispielen und Zitaten aus Gustav Gerber: Die Sprache als Kunst (Bromberg, 1871) in Nietzsche Rhetorik Vorlesung e em "Über
} 
sentido extra-moral o jovem Nietzsche descreverá a gênese da linguagem nos seguintes termos: "Um estímulo nervoso (Nervenreiz), primeiramente transposto (übertragen) em uma imagem $($ Bild $)$ ! Primeira metáfora. A imagem, por sua vez, modelada em um som! Segunda metáfora" (WL/VM §1 KSA 1.875, trad. RRTF). Nesta mesma direção, em notas ao seu Curso de retórica realizado entre os anos de 1872 e 1874, o filósofo escreve:

O homem que forma a linguagem [der sprachbildende Mensch] não apreende coisas ou processos, mas excitações [Reize]: não restitui sensações, mas somente cópias [Abbildung] das sensações. A sensação que é suscitada por uma excitação nervosa não apreende a própria coisa: essa sensação é figurada no exterior por uma imagem [...] Em lugar da coisa, a sensação só apreende uma marca [Merkmal] (Curso de retórica $\$ 3, \mathrm{KGW}$ II 4, Trad. T.C).

Concebida assim, a gênese da linguagem não se revela como um procedimento lógico, mas analógico, uma vez que deriva de um processo mimético que consiste, em última análise, na transposição (Uebertragung) de imagens ${ }^{192}$ a partir de um estímulo nervoso. Num póstumo redigido entre 1872 e 1873, Nietzsche escreve: “A imitação requer uma recepção e, em seguida, uma transposição continuada da imagem recebida em mil metáforas, todas atuando" (Nachlass/FP 1872 - 1874, 19[226], KSA 7.489).

Wahrheit und Lüge im aussermoralischen Sinne”, em Nietzsche-Studien, 17 (1988), pp. 350-368; Claudia Crawford:The beginnings of Nietzsche's theory of language. Berlin: de Gruyter, 1988.

${ }^{192}$ É na Poética de Aristóteles que encontramos a definição de metáfora que acabaria por servir de modelo para toda tradição. Para o filósofo estagirita, "a metáfora consiste no transportar para uma coisa o nome de outra, ou do gênero para a espécie, ou da espécie para o gênero, ou da espécie de uma para a espécie de outra, ou por analogia" (Poética, 1457b 6-9). Em seus escritos sobre retórica, Nietzsche se apropria da ideia aristotélica de metáfora como "transposição" - Nietzsche utiliza o vernáculo Uebertragungcomo correspondente para o termo grego epiphora -, e, junto dela, a ideia implícita de dynamis, que o filósofo alemão interpretará como força: "A força (Kraft) que Aristóteles chama retórica, que é a força de deslindar e de fazer valer, para cada coisa, o que é eficaz e impressiona, essa força é ao mesmo tempo a essência da linguagem: esta se reporta tão pouco como a retórica ao verdadeiro, à essência das coisas; não quer instruir, mas transmitir a outrem (auf Andere übertragen) uma emoção e uma apreensão subjetivas" (Curso de retórica §3, KWG II 4). Contudo, como nota Guervós (2002, p. 25), a definição aristotélica, ao se basear em gênero, espécies, definindo-os em relação à sua essência, não poderia ser compatível com os propósitos nietzschianos, já que pressupõe uma definição de metáfora como uma imagem imprópria do mundo dos objetos, portanto, desprovida de valor filosófico uma vez que é carente de valor epistêmico. Aristóteles escreve: "quanto a palavras estrangeiras, metáforas e outras espécies de nomes raros, ver-se-á que dizemos a verdade, se as substituirmos por palavras de uso comum" (Poética, 1458b 5-31). A metáfora, neste sentido, se apresenta em oposição às palavras usuais. Contra Aristóteles e junto de Lange, a teoria da linguagem de Nietzsche opera de modo a desfazer a dicotomia conceito/metáfora, conforme proposto pela Poética de Aristóteles. 
As palavras, portanto, não derivam da essência das coisas, mas de uma relação ${ }^{193}$ mimética com as representações intuitivas, procedimento que consiste, em última análise, em produzir uma imagem a partir de outra imagem. Num apontamento destinado ao Livro do filósofo, Nietzsche afirma: "Sem embargo, não há uma correspondência com a essência das coisas, se trata de um processo cognoscitivo que não afeta a essência das coisas" (Nachlass/FP 1872 - 1874, 19[236], KSA 7.493).

Nesta acepção, a linguagem não é tida como o invólucro da verdade, mas como imagem e aparência, destarte o objetivo do discurso não é a de transmitir um conhecimento verdadeiro, mas comunicar uma opinião a partir de um efeito estético. Em notas de seu Curso de retórica produzido entre 1872 e 1874, o filósofo escreve: "É o primeiro ponto de vista: a linguagem é retórica, porque apenas quer transmitir uma doxa, e não uma epistêmê" (Curso de retórica §3, KGW II 4, Trad. T.C). Ora, uma vez que o pensamento consciente é a atualidade da relação entre os símbolos da linguagem, dado que tais símbolos são produtos de uma intuição, atividade artística inconsciente, o que a linguagem enuncia não pode ser de modo algum o conhecimento puro das coisas.

Nietzsche ataca os fundamentos de uma concepção referencialista ${ }^{194}$ da linguagem ao refutar a hipótese de que entre as palavras e as coisas exista uma conexão lógica, o que permite dizer que os enunciados linguísticos estão relacionados a um significado ideal ou com a essência das coisas. A "coisa-em-si (tal seria justamente a verdade pura e sem consequências)", afirma o filósofo em Sobre verdade e mentira no sentido extra-moral, "é também para o formador da linguagem, inteiramente incaptável

\footnotetext{
${ }^{193}$ Sobre a concepção de linguagem como relação em Nietzsche, Cf. CORBANEZI, E. Sobre a concepção relacional de linguagem em Nietzsche. Cadernos Nietzsche. São Paulo, n.34 - vol. 1, p. 167 - 187, 2014. ${ }^{194} \mathrm{O}$ referencialismo, na filosofia, tem suas raízes na antiguidade, de modo particular, na filosofia aristotélica. Na filosofia moderna e contemporânea ele surge com a tradição lógico-semântica representada por filósofos como G. Frege, B. Russell, A. Tarski e L. Wittgenstein. Segundo Braida (2009), "O referencialismo consiste na tese de que ser significativo é estar ou poder estar correlacionado com algo diferente (...) Nessa perspectiva de conceituação, a linguagem é concebida como um sistema de objetos significantes cuja significância é uma propriedade decorrente de uma relação de remissão a um outro sistema de objetos, relação esta que bem pode ser denominada referencial. Por isso, denomina-se esta forma de conceituação de referencialismo semântico, o qual tem como cerne a tese de que a remissão a entidades é constitutiva da significatividade" (BRAIDA, 2009, p. 129 - 130). Foi Jacques Derrida (2006) que, em sua obra Gramatologia, apontou Nietzsche como sendo um ponto de ruptura com uma determinada tradição referencialista e metafísica da linguagem. O filósofo da desconstrução escreve: “(...) Nietzsche, longe de permanecer simplesmente (junto com Hegel e como desejaria Heidegger) na metafísica, teria contribuído poderosamente para libertar o significante de sua dependência ou derivação com referência ao logos e ao conceito conexo de verdade ou de significado primeiro, em qualquer sentido em que seja entendido. A leitura e portanto a escritura, o texto, seriam para Nietzsche operações 'originárias' com respeito a um sentido que elas não teriam de transcrever ou de descobrir inicialmente, que portanto não seriam uma verdade significada no elemento original e na presença do logos, como topos noetós, entendimento divino ou estrutura de necessidade apriorística" (DERRIDA, 2006, p. 23). Sobre a noção de referencialíssimo cf. BRAIDA, Celso Reni. Filosofia da linguagem. Florianópolis: FILOSOFIA/EAD/UFSC, 2009, particularmente a segunda parte: Teorias do significado.
} 
(...)" (WL/VM §1 KSA 1.875, trad. RRTF). Portanto, o que as palavras denotam e o que a linguagem enuncia não pode ser de modo algum a essência das coisas, enfim, uma epistêmê, mas apenas uma doxa, uma opinião acerca delas. Nietzsche afirma: "É o primeiro ponto de vista: a linguagem é retórica, porque apenas quer transmitir uma doxa, e não uma epistêmê" (Curso de retórica§3, KWG II 4). Mas diante desta origem retórica da linguagem, como surge a crença de que é possível dizer $a^{195}$ verdade?

Numa conhecida passagem de Sobre verdade e mentira no sentido extra-moral, Nietzsche descreve a relação que a linguagem estabelece com a verdade nos seguintes termos:

Agora, com efeito, é fixado aquilo que doravante deve ser 'verdade', isto é, descoberta uma designação uniformemente válida e obrigatória das coisas, e a legislação da linguagem dá também as primeiras leis da verdade: pois surge aqui pela primeira vez o contraste entre verdade e mentira (WL/VM $\S 1$ KSA 1.875, trad. RRTF).

Na seguinte passagem, Nietzsche estabelece que a concepção da verdade como correspondência ${ }^{196}$ tem seu início na linguagem. A ideia de que a linguagem, a partir de seus signos, está numa relação de correspondência com $a$ verdade, está fundamentada na crença primeira de que entre as palavras e as coisas existe uma conexão mais íntima, de caráter eminentemente metafísico. A crença nesta relação institui no âmbito da comunicação humana uma designação uniformemente válida e obrigatória das coisas e,

\footnotetext{
${ }^{195}$ Utilizaremos o recurso do itálico no artigo ou na preposição que precede o termo "verdade" (por exemplo: $a$ verdade; $d a$ verdade) quando este termo se referir à concepção tradicional de verdade, concepção segundo a qual, há uma única verdade. Segundo Günter Abel (2005, p. 180), no que diz respeito à questão da verdade, podemos encontrar na tradição filosófica três representações basilares: a) a verdade como concordância e adequação entre o pensamento e os objetos; b) verdade como autorrevelação da essência das coisas e c) verdade como atividade de tal procedimento. Abel escreve: "Em todas as três perspectivas é pressuposto, além disso, que não há muitas, mas 'Uma Única Verdade"” (ABEL, 2005, p. 180).

${ }^{196}$ Para Wilcox (1986, p. 337), a interpretação mais corrente entre os comentadores de Nietzsche, de modo particular os americanos, é a de que o filósofo alemão teria operado a partir de duas teorias da verdade notadamente contraditórias, a teoria da verdade como correspondência e a teoria pragmática da verdade. Não obstante, afirma o comentador, tal contradição teria sido desfeita após o filósofo distinguir os dois sentidos de verdade, o que resultou na aceitação do último, o sentido pragmático, em detrimento do primeiro, a verdade como correspondência. Segundo Günter Abel (2005, p. 183), a teoria da correspondência é a forma mais predominante da teoria da verdade, sendo a que mais se aproxima do nosso entendimento do cotidiano. Sua posição fundamental, explica o autor, "é a de que uma proposição (um juízo, uma representação) só e somente só é verdadeira quando concorda com a parte correspondente da realidade - quando, portanto, há correspondência entre a proposição (o juízo, a representação) e o mundo (...)".(ABEL, 2005, p. 183).Para uma reflexão sobre a crítica de Nietzsche à teoria da verdade como correspondência Cf. WILCOX, John T. Nietzsche scholarship and the correspondence theory of truth: the Danto case. Nietzsche-Studien, 15, pp. 337-357, 1986; ABEL, G. Verdade e interpretação. In: MARTON, S. (Org.). Nietzsche na Alemanha. São Paulo: Discurso Editorial, 2005.
} 
sob as leis da linguagem, notadamente as leis gramaticais, cria-se a ilusão de que $a$ verdade se apresenta na linguagem. Tal ilusão, segundo Nietzsche, decorre por dois motivos: o esquecimento da origem retórica da linguagem e o uso habitual das designações:

Ora, o homem esquece sem dúvida que é assim que se passa com ele: mente, pois, da maneira designada, inconscientemente [unbewusst] e segundo hábitos seculares - e justamente por essa inconsciência, justamente por esse esquecimento, chega ao sentimento da verdade. (VM $§ 1$, KSA 1.875, trad. RRTF).

Com efeito, o uso constante e habitual das designações leva ao esquecimento e à inconsciência da origem retórica da linguagem, por conseguinte, ao sentimento do verdadeiro. Em um póstumo do verão de 1872 - começo de 1873, o filósofo escreve: “Por 'verdadeiro' há de se entender somente aquilo que usualmente é metáfora habitual - por conseguinte, só uma ilusão que se fez familiar por um uso frequente e que não é percebida como ilusão (...)" (Nachlass/FP 1872 - 1874, 19[229], KSA 7.491).A designação verdadeira, afirma o filósofo, consiste numa "metáfora esquecida, isto é, uma metáfora, da que se esquece de que é uma metáfora" (Nachlass/FP 1872 - 1874, 19[229], KSA 7.491). É a partir do hábito e do esquecimento que as palavras perdem o caráter metafórico e, por conseguinte, sua potência dinâmica para serem compreendidas como conceitos estáveis ${ }^{197}$. Deste modo, ao propor a origem metafórica e intuitiva do conceito, Nietzsche se afasta da tradicional concepção kantiana-schopenhaueriana que afirmava a origem intelectual do conceito, bem como a natureza discursiva do conhecimento humano.

Segundo Kant, a formação dos conceitos ocorre a partir da faculdade do entendimento. No início da "Estética Transcendental”, Kant escreve: "Por intermédio, pois, da sensibilidade são-nos dados objetos e só ela nos fornece intuições; mas é o

\footnotetext{
${ }^{197}$ Acerca da concepção nietzschiana de conceito, concordamos com a posição de Sarah Kofman (1972) quando esta escreve: "Assim, é ao nível do conceito que a atividade metafórica, a mais dissimulada, torna-se por ela mesma a mais perigosa: graças ao conceito, o homem organiza o universo inteiro nas bem ordenadas rubricas lógicas, sem saber que ele continua então a mais arcaica atividade metafórica. Com efeito, o conceito não é nem uma ideia a priori nem um modelo como ele pretende ser" (KOFMAN, 1972, p. 55). Para a autora de Nietzsche et la métaphore, o filósofo alemão visualiza o conceito como "uma passagem do análogo ao idêntico, do diverso à unidade" (KOFMAN, 1972, p. 59), o que leva Kofman a concluir que "o conceito,abstração cristalizada e geral, é um condensado de metáforas e metonímias múltiplas" (KOFMAN, 1972, p. 64) que, no ambiente teórico de Sobre verdade e mentira no sentido extra moral,é organizado e instituído a partir de um impulso natural de sobrevivência e conservação, jamais por uma faculdade intelectual a priori e abstrata, como a postulada pela Analítica kantiana.
} 
entendimento que pensa esses objetos e é dele que provém os conceitos" (KANT, 1997, p. 61). Pensar, para Kant, significa conhecer por conceitos, logo o conhecimento só pode ser discursivo e não intuitivo, ou seja, só pode ser mediato, pois depende das representações do entendimento, os conceitos. Kant escreve: "O conhecimento de todo o entendimento, pelo menos do entendimento humano, é um conhecimento por conceitos, que não é intuitivo, mas discursivo" (KANT, 1997, p. 102).

Ao seguir a via kantiana, em $O$ mundo como vontade e representação Schopenhauer considera o conceito uma representação abstrata e não intuitiva. $O$ filósofo alemão afirma:

É a razão que fala para a razão, sem sair de seu domínio, e o que ela comunica e recebe são conceitos abstratos, representações não intuitivas, as quais, apesar de formadas uma vez e para sempre e em número relativamente pequeno, abarcam, compreendem e representam todos os incontáveis objetos do mundo efetivo. (SCHOPENHAUER, 2005, p. 86).

Como abstração, o conceito só pode ser objeto do pensamento e de modo algum da intuição, isto é, não pode ser objeto da experiência direta, mas tão somente os seus efeitos $^{198}$. Ao afirmar com Kant a impossibilidade de se conhecer a essência das coisas, o conhecimento, para Schopenhauer, dá-se na mediação por conceitos, logo é discursivo e não intuitivo: "Não podemos, por isso, jamais alcançar um conhecimento evidente de sua essência, mas tão-somente um conhecimento abstrato e discursivo" (SCHOPENHAUER, 2005, p. 86).

Enquanto se distancia da tradição kantiano-schopenhaueriana, o jovem Nietzsche propõe a tese de que os conceitos são derivados apenas da experiência direta da intuição humana. Num póstumo do inverno de 1872-1873, Nietzsche escreve: “Os conceitos podem derivar apenas da intuição (Anschauung)" (Nachlass/FP 1872 - 1874, 23[13], KSA 7.543). Na acepção do jovem Nietzsche, como se vê, a intuição humana consiste numa operação ativa de síntese da multiplicidade percebida, cujo produto são unidades de aparências designadas pelo filósofo como símbolo (Symbol). O processo de criação simbólica, por sua vez, tem início no estímulo (Reiz) sensorial que, segundo Nietzsche, mostra-se como o "pressuposto de toda intuição" (Nachlass/FP - 1872 1874, 23[10], KSA 7.541), ao ser também o pressuposto do conceito. Nietzsche inverte

${ }^{198}$ Cf. Schopenhauer, 2005, p. 86. 
a proposição de Schopenhauer ao afirmar que não é o conceito o pressuposto da palavra, mas é a palavra enquanto metáfora, imagem de uma imagem, o substrato do conceito ${ }^{199}$.

Em sua origem, portanto, a concepção é uma palavra e, como tal, uma transposição metafórica de um estímulo nervoso, isto é, uma transposição de imagem para imagem. O filósofo escreve: “(...) até mesmo o conceito, ósseo e octogonal como um dado e tão fácil de deslocar quanto este, é somente o resíduo de uma metáfora”, e adiante complementa: "a ilusão da transposição artificial de um estímulo nervoso em imagens, se não é mãe, é pelo menos avó de todo e qualquer conceito"(VM §1 KSA 1.875, trad. RRTF).Ao tomar como exemplo o conceito de ser (Sein), Nietzsche argumenta: “'Ser' é a transposição da respiração e da vida sobre todas as coisas: simplificação do sentimento humano da vida" (Nachlass/FP 1872 - 1874, 23[13], KSA 7.543).

Para Nietzsche, não é do relacionamento racional e a intuitivo empírico que surge o conceito, mas do uso concreto da linguagem mediante um procedimento de assimilação exclusiva a partir de uma relação de semelhança e diferença. Quando se desconsidera os traços individuais, o conceito opera de modo a igualar o não igual: "Nós só conseguimos um conceito por este caminho e logo atuamos como se o conceito 'homem' fosse algo real, quando a verdade é que foi formado por nós uma vez que temos prescindido de todos os traços individuais" (Nachlass/FP 1872 - 1874, 19[236], KSA 7.493). Com efeito, a desconsideração dos traços individuais que originam os conceitos se dá mediante a ilusão da identidade, ou, como escreverá num póstumo do inverno de 1872-1873: “(...) mediante a pressuposição de identidades (Identitäten): por conseguinte, mediante falsas intuições (falsche Anschauungen). Vemos um homem andar: a isto chamamos 'andar'. Agora um macaco, um cão: dizemos também 'andar'” (Nachlass/FP 1872 - 1874, 23[11], KSA 7.542). Na medida em que despreza as características individuais, os conceitos surgem como unidades abstratas.

Fruto da ilusão da identidade, o conceito é ponto de partida para a crença no conhecimento. Não obstante, por conhecimento Nietzsche não compreenderá a

\footnotetext{
${ }^{199}$ Schopenhauer estabelece uma relação de primazia do conceito frente à palavra, uma vez que esta, sendo objeto de experiência externa, consiste num mero instrumento de transmissão de signos convencionais. Contudo, o que subjaz à estrutura desta comunicação lingüística são as abstrações dos conceitos enquanto representações não intuitivas, logo é o conceito que dá origem ao processo da linguagem. Caso contrário, se os signos da comunicação estivessem assentados sobre representações intuitivas, afirma Schopenhauer, o discurso seria reduzido a um grande tumulto e numa grande fantasia. Porém, afirma Schopenhauer, "o sentido do discurso é imediatamente intelectualizado, concebido e determinado de maneira precisa, sem que, via de regra, fantasmas se imiscuam" (SCHOPENHAUER, 2005, p. 86).
} 
tradicional relação referencial entre o conceito e o objeto, mas sim um modo de operar com metáforas familiares. Numa anotação póstuma redigida entre os anos de 1872 e 1873, Nietzsche escreve: "Conhecer não é mais que trabalhar com as metáforas preferidas, por conseguinte uma imitação já não percebida como imitação. Portanto, o conhecimento naturalmente não pode penetrar no reino da verdade" (Nachlass/FP 1872 - 1874, 19 [228], KSA 7.490). Dessarte, diferentemente do que foi proposto por Kant e Schopenhauer, o conhecimento que se dá por conceitos não é o resultado de uma operação racional, pois ao ser os conceitos constitutivamente metáforas, o conhecimento humano se restringe ao âmbito da intuição.

Razão e conhecimento, portanto, são ilusões criadas a partir do pressuposto da identidade e da estabilidade dos conceitos. O homem, afirma o filósofo, dispõe o "seu agir como ser 'racional' sob a regência das abstrações" (VM §1 KSA 1.875, trad. RRTF). A necessidade de instituir uma linguagem formal e segura decorre do fato de que o homem, ávido pelo conhecimento $d a$ verdade, "não suporta mais ser arrastado pelas impressões súbitas, pelas intuições" (VM §1 KSA 1.875, trad. RRTF) e, dessa forma, põe-se a universalizar "todas essas impressões em conceitos mais descoloridos, mais frios, para atrelar a eles o carro do seu viver e agir" (VM §1 KSA 1.875, trad. RRTF). Não obstante, a capacidade humana para forjar conceitos é, na ótica do jovem Nietzsche, o que destaca o homem do animal: "Tudo o que destaca o homem do animal depende dessa aptidão de liquefazer a metáfora intuitiva em um esquema de dissolver uma imagem em um conceito" (VM $\S 1$, KSA 1.875, trad. RRTF).

É a necessidade de uma comunicação estável e verdadeira que leva ao uso constante e habitual das metáforas e, por conseguinte, ao esquecimento da origem metafórica do conceito. Assim, a linguagem conceitual serve como um suporte sobre o qual se fundam as relações humanas, pois é a partir dela que se confirma o sentimento moral $d a$ verdade. Na acepção nietzschiana, o homem precisa da verdade na medida em que necessita moralmente de convenções fixas que lhe promovam previsibilidade e segurança nas ações: "é uma convicção moral da necessidade de uma convenção fixa para que possa existir uma sociedade humana" (Nachlass/FP 1872 - 1874, 19[230], KSA 7.492).

Opathos da verdade surge no homem no momento da constatação de que a verdade é um bem, pois é garantia de segurança e bem estar social. Nisto consiste, segundo Nietzsche, sua origem moral: "De onde procede o pathos da verdade no mundo da mentira? Da moral" (Nachlass/FP 1872 - 1874, 19[219], KSA 7.488). A 
promulgação de uma lei ou a normatização de um costume - que em última análise não é outra coisa senão o que Nietzsche designa por "verdade-convenção" -, é o primeiro passo para cessar o bellum omnium contra omnes ${ }^{200}$, sentença utilizada pelo filósofo alemão para descrever o hipotético estado de guerra em que encontrar-se-ia uma sociedade desprovida de verdades-convenções. O filósofo escreve: "Se o estado de guerra (Kriegszustand) deve cessar em qualquer parte, então deve começar com a fixação da verdade, isto é, com uma designação válida e vinculante das coisas" (Nachlass/FP 1872 - 1874, 19[230], KSA 7.492). Os acordos decorrentes da condição de vida gregária adquirem legitimidade, segundo Nietzsche, na linguagem.

O homem se utiliza das metáforas usuais, os conceitos, respeitando as designações obrigatórias e as leis gramaticais da linguagem para, ao fim, chegar à firme convicção e ao sentimento moral de ter dito $a$ verdade. O filósofo escreve: "No sentimento de estar obrigado a designar uma coisa como 'vermelha', outra como 'fria', uma terceira como 'muda', desperta uma emoção que se refere moralmente à verdade (...) (VM $§ 1$, KSA 1.875, trad. RRTF). Dizer $a$ verdade, nesta perspectiva, é respeitar os acordos sociais referentes às designações linguísticas enquanto se faz um uso correto delas, logo uma exigência moral.

Nesta perspectiva, o homem verdadeiro é aquele que adere e respeita as designações convencionadas, quando se mostra sempre previsível e confiável aos seus pares. De modo contrário se comporta o mentiroso que, segundo Nietzsche, "usa as palavras para fazer com que o não-efetivo (Unwirkliche) apareça como efetivo (Wirklich), isto é, faz um uso impróprio do fundamento sólido" (Nachlass/FP 1872 1874, 19[230], KSA 7.492) ${ }^{201}$. Ao inverter nomes, subverte-se a tradicional relação entre o signo e o seu referente, o mentiroso usa inadequadamente as designações

\footnotetext{
${ }^{200}$ Guerra de todos contra todos (N. do A.). Esta expressão aparece em Sobre verdade e mentira no sentido extra-moral de 1873 na seguinte passagem: "Enquanto o indivíduo, em contraposição a outros indivíduos, quer conservar-se, ele usa o intelecto, em um estado natural das coisas, no mais das vezes somente para a representação: mas, porque o homem, ao mesmo tempo por necessidade e por tédio, quer existir socialmente e em rebanho, ele precisa de um acordo de paz e se esforça para que pelo menos a máxima bellum omnium contra omnes (guerra de todos contra todos) desapareça de seu mundo" (VM §1, KSA 1.875, trad. RRTF). Numa clara alusão ao pensamento hobbesiano, Sobre verdade e mentira no sentido extra-moral vem afirmar a tese de que a verdade, e com ela a racionalidade, princípios basilares do contrato social e de todo pensamento político moderno, são ilusões causadas pela linguagem.

${ }^{201}$ Em Sobre verdade e mentira no sentido extra-moral, Nietzsche reproduzirá esta mesma ideianos seguintes termos: "O mentiroso usa as designações válidas, as palavras, para fazer aparecer o não-efetivo como efetivo; ele diz, por exemplo: 'sou rico', quando para seu estado seja precisamente 'pobre' a designação correta. Ele faz mau uso das firmes convenções arbitrárias ou mesmo inversões de nomes" (VM $\S 1$, KSA 1.875, trad. RRTF).
} 
convencionais ao tornar-se imprevisível e, por conseguinte, não confiável: uma ameaça ao pacto social.

Desse modo, é instituído entre os homens um discurso oficial $d a$ verdade, regido por normas gramaticais e estilísticas convencionais e obrigatórias, cujo propósito é garantir a veracidade daquilo que é comunicado, ou melhor, garantir a comunicação $d a$ verdade. O cumprimento destas normas imprime no discurso o selo da verdade enquanto lhe confere poder: "A 'verdade' se converte em um poder, quando nós a liberamos primeiro como abstração" (Nachlass/FP 1872 - 1874, 19[204], KSA 7.481). Mais adiante, escreve: "Em uma sociedade política é necessário um compromisso firme, este se fundamenta no uso corrente de metáforas" (Nachlass/FP 1872 - 1874, 19[229], KSA 7.491). Firme e estável, o conceito é o pressuposto sobre o qual se assentam as relações humanas, logo é o pressuposto para a instituição de uma sociedade política.

Ora, uma vez que a verdade é uma ilusão antropomórfica que se esqueceu de seu caráter ilusório, dizer a verdade, para Nietzsche, consiste em "mentir em rebanho, em um estilo obrigatório (verbindlichen Stile) para todos" (WL/VM §1, KSA, 1.875, trad. RRTF). A forma do discurso, portanto, o seu estilo, pode conferir ao discurso o caráter de veracidade ou falsidade. $\mathrm{O}$ valor do estilo, nesta perspectiva, mostra-se decorrente do compromisso moral que o indivíduo assume com a comunidade e com $a$ verdade. Assim, para o homem do conhecimento, o melhor estilo é aquele cuja obscuridade das impressões individuais tenham sido suplantadas pela clareza do discurso racional, em outros termos, é aquele em que a inconstância das metáforas particulares cede lugar à estabilidade dos conceitos universais.

Intencionalmente não artístico, o estilo obrigatório dos modernos visa à comunicação de conhecimentos puros e verdadeiros e, neste sentido, opõe-se veementemente à antiga arte retórica dos gregos que, conscientemente artística, objetiva apenas provocar um efeito e forjar uma doxa.Tal arte, segundo Nietzsche, só poderia ter nascido na Grécia, “num povo que vive ainda em imagens míticas e que ainda não conhece a necessidade incondicionada da confiança na história; prefere ser persuadido a ser instruído (...)"(Curso de retórica §1, KGW II 4, Trad. T.C). Desta maneira, fundamentada nomythos e nas imagens criadas pela intuição do poeta, a formação do homem grego foi desde cedo orientada por uma educação estética por meio da arte da retórica, portanto, uma formação intuitiva e não conceitual. Então, a afinidade pelo estilo belo e o zelo pela língua materna, características que distanciava o homem grego 
dos bárbaros antigos, povos sem cultura, mas que também é, segundo Nietzsche, o que o distingue radicalmente dos alemães, bárbaros modernos.

Procura-se apresentar de que modo o jovem Nietzsche retoma de Winckelmann e de todo Classicismo alemão uma concepção estético-ética de estilo, o que se mostra evidente na medida em que a noção de estilo, tanto em textos da época de $O$ nascimento da tragédia quanto nos textos posteriores sobre a arte retórica, aparece intimamente ligada ao conceito de formação. No que diz respeito ao primeiro caso, Nietzsche apresenta a cultura trágica dos gregos como o resultado de um antagonismo entre dois estilos opostos, Apolo e Dioniso. É da relação antagônica entre o estilo apolíneo e o dionisíaco surge uma nova transfiguração, primeiramente como estilo lírico e posteriormente como trágico. Pode-se concluir, portanto, que a realização deste novo estilo expressa a existência de uma nova cultura entre os gregos, a cultura trágica, bem como de uma formação do homem fundamentada numa educação estética a partir da arte trágica. Contudo, esta cultura foi paulatinamente suplantada pelo otimismo científico de Sócrates e pela cultura alexandrina, cujo ideal teórico de educação e formação do homem pode ser observado no "novo estilo", o stilo rappresentativo que culminou na ópera italiana moderna. Na obra musical de Wagner, reconhecida como o despertar do estilo trágico, Nietzsche encontra o novo paradigma para a formação do homem e edificação da cultura. Analisar-se-á os textos posteriores a $O$ nascimento da tragédia, momento em que o filósofo abandona a investigação acerca da tragédia grega, investigação fundamentada em preceitos schopenhauerianos e wagnerianos, para refletir sobre a linguagem e a arte retórica num registro próximo de Lange e Gerber. Procurouse mostrar de que modo Nietzsche concebeu a linguagem como o resultado de um procedimento eminentemente artístico, um produto da intuição humana e, desse modo, essencialmente retórica. Pretendeu-se, então, reconstituir a gênese da crença no discurso $d a$ verdade e, a partir dele, a instituição de um estilo obrigatório entre os homens, um estilo destituído de elementos retóricos e que, por isso, é supostamente capaz de comunicar conhecimentos puros e verdadeiros. Para Nietzsche, esta é a concepção de discurso que predomina entre os modernos, o que os coloca em plena oposição com os gregos, povo dotado de uma singular sensibilidade para a arte retórica. 
É neste sentido que surge, para Nietzsche, a oposição entre um estilo científico, destinado à instrução e erudição do homem, e um estilo artístico, destinado à formação estético-ética do homem e edificação da cultura. É a partir desta oposição que Nietzsche pensará o problema do estilo na filosofia. 


\section{CAPÍTULO 4 \\ O ESTILO NA FILOSOFIA \\ Um instrumento para a formação do homem}

É significativa a ideia nietzschiana de que a unidade cultural grega, assim como a sua concepção de barbárie, esteja relacionada à língua e à ideia de educação estética do homem ${ }^{202}$. Ao se referir aos alemães modernos como bárbaros em sua Primeira Extemporânea, Nietzsche parece se aproximar desta ideia grega uma vez que tende a observar a barbárie moderna, particularmente a alemã, a partir do fenômeno da dilapidação da língua alemã, fenômeno que decorre, sobretudo, do modo como a língua materna é utilizada pelos escritores e ensinada pelas instituições de formação alemãs do seu tempo. A aproximação do tema da língua e da linguagem fez com que o jovem Nietzsche se distanciasse dos motivos românticos de Schopenhauer e Wagner, e se aproximasse do Classicismo de Goethe e Schiller.

Destarte, contra a pseudoformação erudita, predominante na Alemanha de seu tempo, Nietzsche propõe ideia de uma formação clássica do alemão, fundamentada no rigoroso e disciplinado estudo da língua alemã a partir do estilo artístico dos clássicos alemães, de modo especial de Goethe e Schiller. Imitar o estilo simples e ingênuo dos clássicos alemães é, para Nietzsche, o caminho para a edificação de um autêntico estilo alemão e, por conseguinte, de uma cultura alemã como unidade de estilo artístico. Neste mesmo ímpeto, Nietzsche afasta a filosofia da meta especulativa da ciência para aproximá-la da arte, cuja finalidade é estética e ética. É neste sentido que pensará o papel pedagógico do filósofo e a finalidade propriamente formadora da filosofia, na qual o estilo simples e ingênuo se mostra essencial.

Diante destas questões, o escopo deste capítulo final consiste em mostrar a relação entre estilo e formação a partir da crítica nietzschiana à formação filisteia de seu tempo, crítica que se apresenta, sobretudo, a partir dos temas da língua e do estilo. Apresentar-se-á a proposta nietzschiana de formação clássica como fundamentada na ideia de uma educação estética a partir do estilo simples e ingênuo dos clássicos alemães. Em seguida, analisar-se-á o estatuto da filosofia no jovem Nietzsche com o objetivo de compreender qual é o papel do filósofo e a finalidade da filosofia e, por conseguinte, o estilo que mais se adapta ao seu fim. Por fim, apresentar-se-á

\footnotetext{
${ }^{202}$ Cf. Nachlass/FP 1872 - 1873, 19 [313], KSA 7.515.
} 
Schopenhauer, o gênio ingênuo nietzschiano, como o exemplo de filósofo formador por excelência. Deste modo, espera-se comprovar esta tese de que o estilo é um instrumento fundamental para que a filosofia realize a sua meta formadora.

Em sua Segunda Extemporânea, Nietzsche retoma a oposição entre cultura e barbárie já apresentada em seu escrito sobre David Strauss, porém com alguns ajustes. O filósofo escreve:

A cultura [Kultur] de um povo, como antagonismo de toda barbárie, tem sido definida em certa ocasião, tenho entendido que com certa razão, como unidade de estilo artístico em todas as manifestações vitais de um povo; esta definição não deve ser entendida mal, como se se tratasse de um contraste entre barbárie e estilo 'belo'; o povo a que se atribui uma cultura simplesmente deve, em toda realidade, ser uma unidade vivente, e não dissociar-se de uma maneira tão lamentável em interior e exterior, em conteúdo e forma. Quem quer anelar e promover a cultura de um povo há de anelar e promover esta unidade superior e cooperar na destruição da moderna tendência à erudição [Gebildetheit] em favor de uma formação verdadeira [wahren Bildung] (...) (HL/Co Ext. II § 4, KSA 1.265).

O estado de barbárie em que se encontra a Alemanha do século XIX, segundo Nietzsche, não está relacionado à má produção artística, isto é, ao feio. Ao retomar Schiller, Nietzsche entende que a contradição entre a cultura e a barbárie tem a ver com a ruptura na esfera política entre o conteúdo, o povo, e a forma, o estado. Não obstante, a cisão entre conteúdo e forma, entre interior e exterior na esfera política é consequência desta mesma ruptura no homem, o que está relacionado com uma equivocada concepção de cultura (Kultur) que predomina nesta nação. Nas palavras do filósofo: "uma tendência à erudição (Gebildetheit) sumamente ambígua e em todo caso antinacional que se chama hoje na Alemanha, com perigosa equivocidade, cultura" (DS/Co. Ext. I $\S$ 1, KSA: 1.159). O termo Gebildetheit consiste em um neologismo pouco usual que provavelmente foi tomado de Wagner, mais especificamente de sua obra Über das Dirigierem. Com o respectivo termo, Nietzsche pretende ressaltar o caráter abstrato de um tipo de formação eminentemente teórica cultivada pelos homens cultos e doutos da 
Alemanha, quando se afirma a distância entre esta formação teórica de uma verdadeira formação, concreta e viva, que afeta diretamente o povo.

Nietzsche atribui este tipo de educação ao demasiado cultivo da interioridade em detrimento da exterioridade, do conteúdo em detrimento da forma, o que dissolve no homem a harmonia entre forma e conteúdo, entre exterior e interior. Cindido e debilitado, o alemão adquiriu uma espécie de aversão a todo tipo de imposição de formas objetivas e, de acordo com o filósofo, "um medo descomunal da palavra 'convenção' e sem dúvida também da coisa convencional” (HL/Co Ext. II § 4, KSA 1.265). Não obstante, o cultivo em demasia da interioridade, para Nietzsche, constitui um perigo iminente:

Repudiam eles com franca ironia o sentido da forma - posto que já tem o sentido do conteúdo: com efeito, são o famoso povo da interioridade [Innerlichkeit]. Agora bem, há também um famoso perigo inerente a esta interioridade: o perigo de que o conteúdo mesmo, que se supõe que exteriormente nem pode ser visto, termine por evaporar-se [...] (HL/Co Ext. II § 4, KSA 1.265).

Os alemães, o povo da interioridade, o desprezo pela forma e o cultivo demasiado do conteúdo podem extirpar o próprio conteúdo. Em outros termos, na medida em que não agem para o exterior, mas para o interior, os alemães não conseguem agir como um povo, mas somente como indivíduo isolado. Segundo Nietzsche, “as belas fibras não estão enlaçadas em um nó comum”, e, logo, “a ação visível não é a ação total e a autorrevelação deste interior, mas tão só uma tentativa débil ou torpe de alguma fibra de tomar por uma vez, em aparência, o lugar do todo" (HL/Co Ext. II § 4, KSA 1.265).

Enquanto sobrepuja a forma e a exterioridade, o cultivo demasiado da interioridade pode acabar com a interioridade. Neste sentido, ao se opor às recentes tendências unificadoras do Estado prussiano, o filósofo afirma: “(...) o que anelamos, mais ardentemente que a restauração da unidade política, é a unidade alemã naquele supremo sentido, a unidade do espírito alemão e da vida alemã, após a destruição do contraste entre forma e conteúdo, entre interioridade e convenção -." (HL/Co Ext. II $\S$ 4, KSA 1.265). Contra a formação da unidade política do estado, Nietzsche irá propor, ao modo do Estado estético de Schiller, uma unidade de estilo na formação alemã (eine 
Stileinheit der deutschen Bildung $)^{203}$. Tal empresa, portanto, deve ter início no combate ao tipo de formação teórica que predomina na Alemanha moderna, designada por Nietzsche em sua Primeira Extemporânea de "formação de filisteu" (Philisterbildung) (DS/Co. Ext. I § 2, KSA 1.164).

A formação de filisteu se apresenta, para Nietzsche, como uma força inibidora da autêntica formação alemã (deutsche Bildung) e, dessa forma, um "inimigo interno" do povo alemão. Em outros termos, na medida em que sua ampla disseminação desenvolve no alemão a falsa ideia de ter uma cultura, esta tendência à erudição se mostra perigosa para a constituição do povo alemão, pois impede o surgimento de uma autêntica formação alemã e consequentemente de uma verdadeira cultura alemã. Os responsáveis pela disseminação e manutenção deste tipo de formação teórica perigo são os "filisteus da formação" (Bildungsphilister) ${ }^{204}$, uma classe de homens eruditos e de natureza essencialmente antiestética, mas que a despeito disso se considera artista e homem da cultura ${ }^{205}$.

Segundo Nietzsche, a palavra filisteu "designa o contrário do filho das musas, do artista, do verdadeiro homem da cultura" (DS/Co. Ext. I $§ 2$, KSA 1.164). O que difere esta noção geral de filisteu do filisteu da formação é o fato deste "ter a ilusão de que é filho das Musas e homem de cultura" (DS/Co. Ext. I $\S 2$, KSA 1.164), enquanto interfere em questões estéticas e culturais pois acredita que "sua 'formação' é justamente a viva expressão da verdadeira cultura" (DS/Co. Ext. I § 2, KSA 1.164). Mas de que modo o autêntico filisteu, homem alheio às Musas, converte-se em filisteu da formação e toma gosto pela arte e pelas questões em torno da estética e da cultura? Em um póstumo da época da redação da primeira extemporânea, o jovem filólogo tece algumas observações acerca do surgimento desta nova classe de filisteu, a do filisteu da formação:

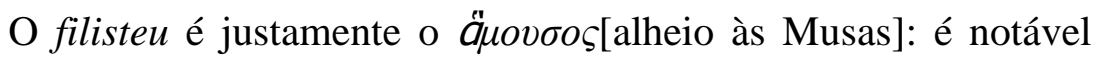
observar como ele apesar disso quer intervir em questões estéticas e culturais. Creio que o que serviu aqui de intermediário tem sido o pedagogo: ele, que por ofício se ocupava da Antiguidade clássica, e que pouco a pouco acreditou que por isso também devia ter um gosto clássico (Nachlass/FP 1873, 27 [56], KSA 7.603).

\footnotetext{
${ }^{203}$ Cf. DS/Co. Ext. I § 1, KSA 1.159.

${ }^{204} \mathrm{Cf}$. nota 12 .

${ }^{205}$ Cf. DS/Co. Ext. I § 2, KSA 1.164.
} 
Num primeiro momento, Nietzsche identifica o pedagogo como o elo entre o filisteu e o filisteu da formação. O ofício da pedagogia, por exigir o contato com a antiguidade clássica e com a autêntica cultura dos gregos, leva o filisteu não só à ilusão de que possui um gosto artístico, mas que este gosto é clássico. Não obstante, ele não percebe a distinção entre uma autêntica formação artística, como a dos gregos do período clássico, e a erudição artística moderna. Em outro apontamento póstumo, também de 1873, Nietzsche esboça uma nova hipótese sobre a origem do filisteu da formação, na qual reconhece no erudito o intermediário entre o autêntico filisteu e o da formação. O filósofo escreve:

Origem do filisteu da formação [Entstehung des Philisters der Bildung]. Em si a formação sempre se reduz a círculos muito exclusivos. O autêntico filisteu se mantém distante deles. O erudito se faz de intermediário, ele acreditava na Antiguidade clássica e valorava os artistas como tipos suspeitos. Hegel pôs em circulação nas universidades muita estética. O público dos "Almanaques" é o público de sempre, jornais da tarde. Nos anos cinquenta os realistas, Julian Schmidt. Pouco a pouco se forma o público das conferências populares, é como um poder, tem simpatias, pressupostos etc. [...] (Nachlass/FP 1873, 27 [52], KSA 7.602).

Com efeito, Nietzsche reconhece no erudito o elo entre o filisteu e o filisteu da formação. São escritores, jornalistas, artistas e outros homens cultos que, por ignorar sua condição mesquinha de filisteu, toma sua erudição como expressão viva de uma cultura autêntica, ou nos termos do próprio filósofo "se sente firmemente convencido de que sua ‘formação' é justamente a viva expressão da verdadeira cultura alemã” (DS/Co. Ext. I $§ ~ 2$, KSA 1.164). A ampliação das discussões sobre estética nas universidades, realizada por professores como Hegel; a influência do realismo literário, bem como de escritores e jornalistas como Julian Schmidt ${ }^{206}$ que, através de almanaques e periódicos levam a arte, a crítica da arte ao grande público dos jornais, faz com que aos poucos se "forme" o público das conferências populares e, com ele, a perigosa confusão entre esta tendência à erudição e a cultura.

Na Alemanha moderna, afirma Nietzsche, o tipo do filisteu da formação está por toda parte e, aonde quer que vá, tem a impressão de si mesmo no contato frequente com

206 Heinrich Julian Schmidt (1818-1886) foi um escritor, jornalista, crítico e historiador da literatura prussiano. Em Leipzig, Junto com Gustav Freytag, outro jornalista atacado por Nietzsche, Schmidt editou periódico Die Grenzbotende 1848 a 1861. Neste ano, se mudou para Berlim onde trabalhou como editor chefe doBerliner allgemeine Zeitung, um dos jornais mais influentes da Alemanha deste período. 
as pessoas cultas de sua espécie. Também se reconhece nas instituições públicas e nos centros escolares, de cultura e de arte, que se organizam em consonância com sua erudição e de acordo com suas necessidades ${ }^{207}$. Da constante impressão de si mesmo em todos os lugares, o filisteu da formação "deduz uma unidade de estilo na formação alemã, enfim, uma cultura" (DS/Co. Ext. I $\S 2$, KSA 1.164). Haja vista que a cultura pressupõe "uma diversidade que conflua na harmonia de um único estilo" (DS/Co. Ext. I $\S 2$, KSA 1.164), ele toma aquela unidade da impressão de si mesmo como uma unidade de estilo na formação, ou seja, como uma autêntica cultura. Nietzsche considera que a uniformidade constatada pelo filisteu da formação não consiste em uma unidade de estilo, pelo seu contrário, corresponde à barbárie. Nietzsche escreve:

O que vê ao seu redor são necessidades exatamente iguais e opiniões similares; aonde vai, lhe envolve de imediato a atadura de uma convenção tácita acerca de muitas coisas, em particular os assuntos da religião e da arte: esta imponente uniformidade, este tutti uníssono que, sem mediar voz de mando, estala ao instante, lhe induz a crer que aqui há uma cultura. Mas pelo fato de ter um sistema, o filisteíssimo sistemático e predominante não é todavia cultura, e nem sequer má cultura, mas seguirá sendo só o contrário, isto é, barbárie com fundamentos consistentes (DS/Co. Ext. I § 2, KSA 1.164).

Com efeito, a imponente uniformidade da formação de filisteu se confirma no círculo cada vez mais amplo de homens semelhantes a ele. Por onde quer que vá, depara-se com uma rígida convenção e padronização de ideias e opiniões consoantes a sua, seja em questões estéticas, ou religiosas. No entanto, o que o filisteu da formação toma por cultura é justamente o seu contrário, a barbárie, ainda que sistematizada. Para Nietzsche, tal processo de uniformidade e padronização deste tipo de formação se dá quando se exclui e se recusa o verdadeiro estilo. O filósofo escreve:

Pois toda essa unidade da impressão que constantemente nos salta aos olhos em toda pessoa culta da Alemanha atual só chega a ser unidade por meio da exclusão e negação, consciente ou inconsciente, de todas as formas e exigências artisticamente produtivas de um verdadeiro estilo [wahren Stils] (DS/Co. Ext. I $\S 2$, KSA 1.164).

${ }^{207}$ Cf. DS/Co. Ext. I § 2, KSA 1.164. 
O sentimento de unidade na formação de filisteu é apenas aparente. Trata-se da conformidade e consonância de atos e opiniões, mas não de uma verdadeira unidade estilística. A unidade em relação à formação filisteia que, segundo Nietzsche, constantemente salta aos olhos do alemão, é por negar e excluir aquilo que é condição para a cultura: a unidade de estilo (Einheit des Stiles).

Por unidade de estilo, Nietzsche entende uma totalidade, uma forma geral para a qual as partes individuais confluam de modo a constituir uma unidade estilística, isto é, uma cultura objetiva e verdadeira. Ao negar as formas e exigências artísticas de um verdadeiro estilo, o filisteu da formação nega o princípio formador tanto do homem quanto do povo e da cultura. Assim, se Nietzsche entende a cultura como unidade de estilo artístico em todas as manifestações da vida de um povo, isto só é possível se partir de um critério estilístico objetivo como parâmetro para a ação dos homens individuais. Em outros termos, cada homem, ao agir de acordo com um único estilo objetivo constitui um povo e reafirma a totalidade estilística que é a cultura. Na medida em que suas ações negam qualquer critério estilístico objetivo, o filisteu da formação não constitui uma cultura, mas seu oposto, uma "não-cultura" (Nicht-Kultur) ou, quando muito, uma "barbárie estilizada" (stilisirten Barbarei) (DS/Co. Ext. I § 2, KSA 1.164)

Desse modo, no que se refere ao filisteu da formação, ainda que haja certa semelhança entre as suas ações e opiniões, tal semelhança só tem a ver com o conteúdo, pois, no tocante à forma não se pode dizer o mesmo. Em outros termos, as ações do filisteu da formação nunca concorrem para um todo estilístico, isto é, não ultrapassam o caráter individual e subjetivo para constituir uma unidade estilística e, dessa forma, não há uma cultura. O filósofo escreve: "Se lhe dá (ao filisteu da formação) a liberdade de eleger entre uma ação conforme a um estilo e a oposta, agarra sempre a última, e como a agarra sempre, todas suas ações ficam marcadas com o selo negativamente uniforme. Neste selo reconhece o caráter da 'cultura' alemã por ele patenteada"(DS/Co. Ext. I $§ 2$, KSA 1.164). Logo, por negar repetidamente qualquer estilo objetivo, o filisteu da formação acaba por desenvolver um sistema coerente de ações negativas que Nietzsche designará de um "sistema da não-cultura" (System der Nicht-Kultur) (DS/Co. Ext. I § 2, KSA 1.164), pois, segundo o filósofo, ele passa a ter "precisamente por cultura o que nega a cultura" (DS/Co. Ext. I $§ 2$, KSA 1.164), isto é, a barbárie: confusão caótica de todos os estilos ou a ausência de um estilo.

A aversão do filisteu pela ideia de convenção e pela ideia de forma se torna manifesto na literatura alemã moderna, marcada pelo constante processo de dilapidação 
da língua alemã em nome de uma linguagem do "tempo atual" (Jetztzeit). As raízes desta tendência na influência que a filosofia hegeliana exerceu sobre o filisteu da formação. Nietzsche escreve:

Uma filosofia que, entre pregas e franjas, ao estilo das transparências de $\operatorname{Coos}^{208}$, encobria o credo filisteu de seu autor, inventou ademais uma fórmula para divinizar a vida cotidiana: esta filosofia falava da racionalidade de todo o real, e assim captou as simpatias do filisteu da formação, a quem também lhe agrada as pregas e franjas, mas que, sobretudo, só se concebe a si mesmo como real e trata sua realidade como medida e razão do mundo (DS/Co. Ext. I $§ 2$, KSA 1.164).

Surge, com o idealismo hegeliano, a ideia de que a linguagem deve ser a expressão racional e subjetiva do seu tempo, um tempo fugaz com o qual Hegel designou a modernidade ${ }^{209}$. Antes de Nietzsche, Schopenhauer já havia se posicionado contra esta tendência moderna.

Schopenhauer acusa os filósofos idealistas de terem introduzido na Alemanha esta linguagem da "atualidade", caracterizada pelo estilo afetado e prolixo ao qual designou stile empesé ${ }^{210}$. Fichte foi o responsável por iniciá-lo; Schelling por aperfeiçoá-lo e Hegel por levá-lo ao extremo ${ }^{211}$. Por isso, desencadeou um processo progressivo de dilapidação da língua alemã em nome da linguagem da "atualidade": "Nobre atualidade", escreve Schopenhauer, "magníficos epígonos, um gênero que cresceu com o leite materno da filosofia hegeliana". Por escreverem de modo pesado e confuso, Schopenhauer se refere a estes filósofos como "paquidermes do estilo". E acrescenta de maneira enérgica: “(...) Fora, paquidermes, fora! Isto é a língua alemã !

\footnotetext{
${ }^{208}$ Dentre os trajes utilizados pelas cortezãs de Atenas, o mais conhecido é a coa, que recebe esse nome da ilha grega de Coos.

${ }^{209}$ Acompanhamos aqui a interpretação de Habermas (2000, p. 09) acerca do conceito de modernidade. Para o filósofo de Frankfurt, Hegel foi o primeiro filósofo a desenvolver um conceito claro de modernidade, isto é, a elevar o termo modernidade a um estatuto conceitual. Segundo ele, a utilização hegeliana desse conceito teria ocorrido num contexto sobretudo histórico, no qual o irromper dos "novos tempos" fora identificado com a expressão "tempos modernos". No entanto, se para o Ocidente cristão a expressão "novos tempos" remete a uma experiência escatológica do tempo, configurada na espera pelo Juízo Final, o conceito secular de tempos modernos expressa, segundo Habermas, a convicção de um futuro que já se iniciou e que se faz presente, em suma, de uma época orientada para o novo. Com o conceito de modernidade, Hegel teria traduzido filosoficamente uma experiência inédita do tempo entendido como passagem e transição para um novo período. O Zeitgeist (espírito do tempo) hegeliano, expressa justamente esta caracterização do presente "como uma transição que se consome na consciência da aceleração e na experiência da heterogeneidade do futuro" (HABERMAS, 2000, p. 10). Modernidade, portanto, não é uma época, mas o modo de se perceber tempo de uma dada época.

${ }^{210}$ Cf. Schopenhauer, 2009, p. 534-535.

${ }^{211}$ Cf. Schopenhauer, 2009, p. 529.
} 
Nela se expressaram homens, nela cantaram grandes poetas e escreveram grandes pensadores (...) $)^{212 "}$ (SCHOPENHAUER, 2009, p. 553-554).

Para Schopenhauer, o cultivo deste estilo da "atualidade", na Alemanha, é um indício de barbárie e decadência do gosto, cuja causa está relacionada ao abandono do ensino das línguas antigas neste país. O filósofo escreve: "Mas se alguma vez, tal e como ameaça nossa época, se deixem de ensinar as línguas antigas, surgirá uma nova literatura constituída de escritos tão bárbaros, vulgares e indignos como jamais houve" (SCHOPENHAUER, 2009, p. 571). Cada vez mais mutilada e empobrecida, afirma o filósofo, a língua alemã "vai degenerando pouco a pouco em um miserável jargão" (SCHOPENHAUER, 2009, p. 571).

O declínio do ensino das línguas antigas também fomenta cada vez mais o mercado das traduções das obras clássicas, o que, para Schopenhauer também é um sintoma da iminente barbárie alemã. Em Parerga e Paralipomena, o filósofo considera a tradução feita em 1830 para o alemão do Corpus Juris (Corpo de lei) ${ }^{213}$ como "um sinal inequívoco da ignorância na base de toda erudição que é a língua latina; isto é, um sinal de barbárie" (SCHOPENHAUER, 2009, p. 498-499). As traduções para o alemão de obras antigas, segundo o filósofo, é um péssimo sintoma e, ao chegar a esse extremo, afirma: “então adeus ao humanismo, ao gosto nobre e o sentido elevado! A barbárie volta apesar das ferrovias, da eletricidade e dos dirigíveis" (SCHOPENHAUER, 2009, p. 498-499).

Em contraste com esta tendência literária da "atualidade", Schopenhauer destaca o engenho, a sabedoria e o rigor com os seus antepassados literatos trataram a língua alemã. O filósofo escreve: "Mas a eles seguem em nossos dias uma geração de rascunhadores rudes, ignorantes e incapazes que, com suas forças e união, fazem negócio destruindo aquela antiga obra de arte com a dilapidação das palavras" (SCHOPENHAUER, 2009, p. 553). Unidos em nome da fama e do dinheiro, os escritores alemães da "atualidade" mantêm-se cúmplices do grosseiro anseio popular por uma linguagem do "tempo atual"(Jetztzeit). Segundo Schopenhauer: "uma grande quantidade de escritores vive exclusivamente da extravagância do público de não querer ler nada além do que se imprime hoje: os jornalistas (Journalisten)" (SCHOPENHAUER, 2009, p. 514).

\footnotetext{
${ }^{212}$ Nietzsche reproduz literalmente esta última passagem em DS/Co. Ext. I § 12, KSA: 1.227.

${ }^{213} \mathrm{O}$ Corpus Juris (Corpo de lei) é a base da jurisprudência latina e foi publicado entre 529 e 534 d.C. por ordens do imperador Justiniano I.
} 
No entanto, a despeito do alto apreço do público em relação à linguagem do "tempo atual", Schopenhauer afirma: "não existe maior erro que crer que a última palavra pronunciada é sempre a mais correta, que todo escrito com posteridade é uma melhora do que se escreveu antes, e que toda transformação é um progresso" (SCHOPENHAUER, 2009, p. 515). Ademais, para o autor de $O$ mundo como vontade e representação, "o novo raramente é o bom; porque o bom é o novo só por um breve tempo"(SCHOPENHAUER, 2009, p. 517). Nesta perspectiva, o que torna latente a diferença entre a grande literatura, como a dos clássicos alemães, da literatura vulgar dos alemães da "atualidade" é, sobretudo, o seu poder de permanência no tempo. Foi por meio do estudo atento dos clássicos, cujo procedimento poético visa à transfiguração da realidade em um estilo artístico ideal e objetivo, que Goethe se tornou um clássico e eternizou a sua poesia, procedimento oposto ao dos escritores da "atualidade", cujo estilo subjetivo visa a expressar a fugacidade do "tempo atual". Quando se alinha ao classicismo de Goethe, Schopenhauer considera a subjetividade no estilo um defeito nativo da Alemanha moderna:

A subjetividade é um defeito estilístico que hoje em dia se faz cada vez mais frequente devido ao estado decadente da literatura e ao abandono das línguas antigas, mas que somente é nativo da Alemanha. Consiste em que ao escritor lhe basta saber ele mesmo o que opina e quer dizer; o leitor já verá como averiguálo (SCHOPENHAUER, 2009, p. 517).

Para Schopenhauer, escrever subjetivamente é como criar um monólogo quando, na verdade, o dever do escritor é estabelecer um diálogo o mais claro e objetivo possível com o leitor. Dessa maneira, deve-se evitar a prolixidade na escrita e, para tanto: "o estilo não deve ser subjetivo, mas objetivo; para isso é necessário colocar as palavras de modo que obriguem diretamente o leitor a pensar exatamente o mesmo que o autor pensou"(SCHOPENHAUER, 2009, p. 517).

$\mathrm{Na}$ esteira da crítica schopenhaueriana da linguagem, Nietzsche considera que a ausência de uma unidade estilística na Alemanha decorre, sobretudo, do fato de que o alemão moderno já não tem apreço e não cultiva a língua alemã falada, o que compromete a instituição de um estilo alemão e, por conseguinte, de uma cultura alemã. Em sua Primeira Extemporânea, Nietzsche escreve: 
Falta aqui um terreno natural, o apreço, o manejo e o cultivo artístico da linguagem falada. Posto que isto, como os próprios termos "conversa de salão", "sermão", "discurso parlamentário" expressam, não constituiu todavia um estilo nacional em todas as manifestações públicas, e, ademais, nem sequer se chegou a sentir a necessidade de que haja um estilo [...] (DS/Co. Ext. I § 11, KSA 1.220).

Quando negligencia o caráter objetivo da língua, indiferente aos seus aspectos formais e normativos, cada indivíduo, autonomamente, regula o seu modo de falar de acordo com suas necessidades. A falta de rigor e os maneirismos linguísticos são indícios do pouco apreço que o alemão tem por sua língua materna, bem como do seu descompromisso com a busca de um estilo artístico autenticamente alemão. Como Schopenhauer, Nietzsche associará essa autonomia no modo de falar do alemão com a dilapidação da linguagem na literatura alemã moderna. O filósofo escreve:

[...] e posto que todos aqueles que falam na Alemanha não foram além de alguns ingênuos experimentos com a língua, o caso é que o escritor não tem nenhuma norma unitária e sim certo direito de lutar por sua conta com a língua: e daí provém, como consequência, a dilapidação sem limites da língua alemã do "tempo atual" [deutschen Sprache derJetztzeit], que Schopenhauer descreveu de maneira mais enérgica (DS/Co. Ext. I $\S 11$, KSA 1.220).

Ao principiar na dilapidação sem limites da língua, os defensores da linguagem alemã do "tempo atual” se caracterizam pela oposição radical à tradição, em particular ao estilo dos grandes escritores da língua alemã, como Lessing, Winckelmann, Goethe, Schiller, aos quais Nietzsche se refere como os "nossos clássicos" (unsere Klassiker). Quando se refere a Schopenhauer, o jovem filósofo escreve: "Se isto segue assim disse em certa ocasião (Schopenhauer) -, no ano de 1900 já não se entenderá bem os clássicos alemães (deutschen Klassiker), posto que a única língua alemã que se conhecerá será o jargão miserável do nobre 'tempo atual' (Jetztzeit)" (DS/Co. Ext. I $\S 11, \mathrm{KSA} 1.220)$.

Segundo Nietzsche, a opinião desses novos “árbitros da língua e da gramática alemãs" do "tempo atual" é a de que o estilo desses escritores é ultrapassado e, por isso, não pode servir de parâmetro para os escritores atuais. Ao seguir esta sugestão, afirma Nietzsche: "os nossos clássicos não podem seguir sendo modelo de nosso estilo 
(unseren Stil), porque empregam uma grande quantidade de termos, expressões e construções sintáticas que nós já perdemos” (DS/Co. Ext. I § 11, KSA 1.220).

Enquanto rejeita o tratamento rigoroso e artístico constatado no estilo dos escritores clássicos da língua alemã, surge na Alemanha moderna uma nova voga literária cuja marca principal é constante experimentação e dilapidação da língua alemã na busca incessante do novo, enfim, do que é mais "atual”. Em tom pejorativo, Nietzsche denomina este novo estilo alemão de estilo jornalístico (Zeitungsstiles) ${ }^{214}$. Os escritores deste novo estilo são recebidos pelos homens cultos da Alemanha do século XIX como os "novos clássicos alemães" (der neuen deutschen Klassiker) ${ }^{215}$, e, neste sentido, são eleitos os novos modelos do estilo alemão ${ }^{216}$. Entre esses "novos clássicos alemães", Nietzsche destaca David Strauss, o escritor que será o tema de sua primeira extemporânea.

Primeiramente, entende-se que o polêmico escrito sobre o famoso escritor alemão não é conduzido por motivos estritamente pessoais, ainda que tais motivos sejam incontestáveis ${ }^{217}$. Grosso modo, Strauss não é o objeto da preocupação nietzschiana e tampouco o seu livro, A antiga e a nova fé, mas sim a fama que se assomou ao escritor e o êxito obtido pela obra ${ }^{218}$. Em um póstumo do ano de 1873, o jovem filósofo escreve: "Para nós o livro de Strauss não é um acontecimento, mas só o seu êxito. Nele não há nenhuma ideia que tenha valor e que se possa considerar boa e nova” (Nachlass/FP 1873, 27 [66], KSA 7.606). Se no que tange a matéria o livro de Strauss não apresenta nada que seja digno de atenção, já o sucesso do autor e o êxito do livro em meio à opinião pública são, para Nietzsche, acontecimentos dignos de nota na

\footnotetext{
${ }^{214}$ Cf. DS/Co. Ext. I § 12, KSA 1.227.

${ }^{215}$ Cf. DS/Co. Ext. I § 1, KSA 1.159.

${ }^{216} \mathrm{Cf}$. DS/Co. Ext. I § 11, KSA 1.220.

${ }^{217}$ Neste sentido, defendemos que a despeito de toda discussão em torno do contexto e dos motivos que supostamente levaram Nietzsche a se ocupar de um escritor como David Strauss em sua Primeira Extemporânea, o alcance crítico e filosófico deste escrito não deve ser minimizado por abordagens biográficas que o reduzem à condição de uma mera "encomenda" ou ao cumprimento do dever de um discípulo para com o seu mestre, Wagner.De fato, na época da redação dessa Extemporânea o jovem Nietzsche ainda se encontravamuito ligado a Wagner, o que torna possível que sua investida contra o recente livro do teólogo alemão David Strauss seja fruto de seu afã em ser útil ao mestre. Wagner tinha um acerto de contas com Strauss por este ter se posicionadoa favor do músico Fran Lachner, seu predecessor na corte de Luis II da Baviera. Não obstante a legitimidade dos referidos dados históricos, entendemos que estes não podem comprometer a autenticidade e o profundo alcance filosófico deste escrito na medida em quenele nos deparamos com motivos autenticamentenietzschianos, como a crítica da cultura e o anti-socratismo já desenvolvido em escritos anteriores como em $O$ nascimento da tragédia. ${ }^{218}$ David Strauss publica em 1872 Das alte und neue Glaube, sua última obra, mas também a de maior sucesso ganhando seis edições em menos de dois anos. A referida obra apresenta ao leitor uma espécie de justificativa do itinerário intelectual do autor, desde o abandono daquilo que designa por "antiga fé", a doutrina cristã, até sua adesão à "nova fé" que, em linhas gerais, consiste numa visão materialista da história justificada hegelianamente.
} 
medida em que se revelam como sintomas de uma cultura em declínio. Em um póstumo lê-se: "Schopenhauer diria de Strauss: é um autor que não vale a pena ser folheado, e muito menos ser estudado: exceto para aqueles que querem medir o grau da estupidez atual" (Nachlass/FP 1873, 27 [50], KSA 7.601).

À vista disto, o ataque de Nietzsche a Strauss ocorre em duas vias críticas: primeiramente ao "devoto", ou seja, ao seu pensamento; e, em seguida, ao "escritor", isto é, ao seu estilo. Em linhas gerais, não é apenas por expressar pensamentos perigosos acerca da filosofia, da ciência, da arte e da religião que Strauss compromete a formação alemã, mas também pela forma que expressa tais pensamentos. É pelo estilo, ou melhor, falta de unidade de estilo em seus escritos. Isto porque, para Nietzsche, esta falta na obra de Strauss não é apenas indício do declínio cultural em que se encontra a Alemanha do século XIX, mas é também uma ameaça iminente ao próprio espírito alemão.

Como um típico filisteu da formação, Strauss é um homem culto e de tendência científica, porém de "natureza totalmente antiestética" (unaesthetische Natur) (Nachlass/FP 1873, 27[54],KSA 7.602). No entanto, a despeito disso, como um típico filisteu da formação Strauss também arroga a si o direito de ser chamado de "clássico". No tocante aos anseios do autor de A antiga e nova fé, Nietzsche se empenha em provar que Strauss não é, como se pensa, um prosista clássico, mas essencialmente moderno. Primeiramente, porque a obra de Strauss não corresponde ao princípio clássico do totum ponere $^{219}$, o que, em linhas gerais, afirma que sua obra é destituída de proporções harmoniosas, logo não constitui um todo orgânico e coeso como deveria ser uma obra clássica $^{220}$. Ainda que se leve em conta o nexo lógico entre suas partes, segundo Nietzsche, o livro de Strauss se apresenta fragmentado e pouco orgânico, na medida em que, segundo o filósofo, não há uma ligação coerente entre as questões que dão nomes às partes do livro ${ }^{221}$.

Um segundo motivo pelo qual Strauss não é um clássico, segundo Nietzsche, é o fato dele não ter um estilo, o que lhe obriga a adquiri-lo de outros. Nietzsche escreve:

\footnotetext{
${ }^{219} \mathrm{Cf}$. nota 06.

${ }^{220}$ Cf. DS/Co. Ext. I $\S 9$, KSA 1.204.

${ }^{221}$ As questões que nomeiam as quatro partes de A antiga e nova fé são as seguintes: Primeira questão: somos ainda cristãos?; Segunda questão: temos ainda religião?; Terceira questão: como concebemos o mundo?; Quarta questão: como ordenamos nossa vida?. Cf. STRAUSS, D. La antigua y la nueva fé. Trad. Ramón Ibañez. Madrid: F. Sempere y Compañía, 1900.
} 
Vamos revelar um segredo: nosso magister nem sempre sabe o que prefere ser, se Voltaire ou Lessing, mas de nenhuma maneira quer ser um filisteu, e se for possível, é seguro que prefira ser os dois, Lessing e Voltaire - para que se cumpra o que está aí escrito: "não tinha nenhum caráter, mas que quando queria tê-lo, antes tinha que adquiri-lo" (DS/Co. Ext. I § 9, KSA $1.204)$

A incapacidade para a unidade de estilo consiste na característica geral do filisteu da formação, logo é também a de Strauss. Seu modo de proceder consiste em produzir um mosaico de estilos inspirados em autores autenticamente clássicos e geniais, como Voltaire e Lessing, enquanto se deduz que Strauss, também é um gênio e um clássico. Nietzsche deduz a falta de estilo de Strauss de sua falta de caráter, o que faz dele um ator: "quando se senta a escrever, põe uma cara que não muda, como se estivesse pousando para um retrato, e mostra ora a cara lessinguiana ora a volteriana (...) o tenho por um ator que faz o papel de gênio ingênuo e de clássico" (DS/Co. Ext. I $§ 10$, KSA 1.216), não obstante, afirma Nietzsche, ele é um mau ator, pois tudo aquilo que imita, imita $\mathrm{mal}^{222}$.

A ausência de caráter num escritor é, segundo Nietzsche, um defeito grave na medida em que o impele a mostrar sempre aquilo que não é, ao passo que o escritor de caráter sempre se apresenta como é, de maneira sincera, simples e ingênua. A simplicidade do estilo (Simplicität des Stil), portanto, tende a ser uma característica central do gênio ingênuo, logo um atributo necessário para todo escritor que deseje um dia ser um clássico. Nietzsche escreve: “ (...) Esta simplicidade tem sido sempre a característica do gênio, o único que tem o privilégio de expressar-se com sensibilidade, naturalidade e ingenuidade (...) ", e acrescenta "Mas o escritor genial não se revela somente na simplicidade e no caráter peremptório da expressão: sua força excessiva o leva a jogar com os conteúdos, ainda que estes sejam perigosos e difíceis”(DS/Co. Ext. I $\S 10$, KSA 1.216). Os gênios verdadeiramente ingênuos, afirma Nietzsche, são suficientes fortes para fazer da multiplicidade de conteúdos uma simplicidade de estilo. Eles não precisam de nada que já não tenham; não usam máscaras e andam estão sempre com "pouca roupa", mas ainda assim aparece mais solenemente que qualquer outro escritor trajado. Nietzsche escreve: "Mas com isso tem feito muito o escritor, ao obrigar os seus leitores a vê-lo mais solene que qualquer outro escritor que vai vestido

\footnotetext{
${ }^{222} \mathrm{Cf}$. DS/Co. Ext. I § 10, KSA 1.216.
} 
com mais roupa. É o caminho para chegar a ser algum dia um clássico" (DS/Co. Ext. I § 10, KSA 1.216).

Diante disso, como atribuir o título de "novos clássicos alemães" a escritores cuja característica principal reside na refutação da simplicidade e ingenuidade inerentes ao estilo dos autênticos "clássicos alemães"? A incoerência parece ser ainda maior quando se pretende o estilo jornalístico do "tempo atual" como um modelo para o estilo alemão, pois como extrair um estilo modelar de uma literatura cuja característica principal é caos estilístico, isto é, a refutação de toda e qualquer norma unitária da linguagem ou unidade estilística objetiva em nome da autonomia subjetiva do autor? ${ }^{223}$ Nietzsche escreve:

Pois bem, o traço mais característico dessa pseudocultura do filisteu da formação é ver como logra para si o conceito de clássico e de escritor exemplar - ele, que só se mostra forte na hora de rechaçar um estilo de cultura verdadeira e artisticamente rigoroso, e que com essa insistência e rechaço logra uma uniformidade na expressão que quase parece ser uma unidade de estilo (DS/Co. Ext. I § 11, KSA 1.220).

Não obstante, a impressão de que com a ausência de um estilo rigoroso obtém-se um novo estilo e uma nova cultura, como se vê, é apenas aparente, haja vista que de uma qualidade negativa não é possível se instituir uma cultura positiva. O contato diário do alemão com a linguagem dos jornais e revistas faz com que gradativamente ele incorpore esta linguagem do "tempo atual". Destarte, na mesma proporção em que o "novo estilo" se fortalece, a língua alemã padece. Na perspectiva de Nietzsche, os responsáveis pelo disseminar e oficialização deste estilo jornalístico e desta formação douta do filisteu da formação são as instituições de formação (Bildungs-anstalten) alemãs organizadas de acordo com as tendências eruditas do primeiro e, neste sentido, atuam de acordo com as suas necessidades.

Em Sobre o futuro de nossas instituições de formação, escrito póstumo do início de 1872, Nietzsche considera que a impotência para a fundação de uma autêntica cultura alemã advém da decadência das instituições de formação, que, em sua época, apresentam-se dominadas por tendências político-pedagógicas perigosas, de caráter eminentemente democrático. Tais tendências, argumenta Nietzsche, apresentam-se sob dois impulsos aparentemente contrários, contudo, igualmente nocivos em seus efeitos:

${ }^{223} \mathrm{Cf}$. DS/Co. Ext. I § 11, KSA 1.220. 
"por um lado, o impulso até a maior ampliação da formação possível; por outro lado, o impulso de redução e enfraquecimento da mesma" (BA/EE, prólogo, KSA 1.643). Em outros termos, o alargamento da educação para o maior número de pessoas possível, como previsto na primeira tendência, só é possível por intermédio do abandono das pretensões supremas e soberanas da educação contidas na segunda.

Quando se persegue o objetivo de modernizar as instituições alemãs de formação, isto é, de conformá-las à época, estes impulsos, diz Nietzsche, desviam-se "das sublimes tendências originárias de sua fundação", enquanto contraria os propósitos da natureza, cuja lei necessária consiste no estreitamento e na concentração da formação de poucos. Distante da natureza, tais impulsos só podem dar conta de fundar uma cultura fictícia (erlogene Kultur), jamais uma cultura autêntica. Mas quais são os riscos de se promover uma ampliação e redução dos meios educacionais? E por que tal tendência deve ser evitada?

Primeiramente, a ampliação dos meios educacionais tem como consequência a barbárie na medida em que inviabiliza uma educação rigorosa, cujos princípios são o hábito e a obediência. Diante destas duas tendências pedagógicas, tais princípios teriam sido substituídos pela ilusão da emancipação racional, que, segundo Nietzsche, "debilita a educação a tal ponto que não pode mais fundar nenhum privilégio nem garantir nenhum respeito. Entendida assim, esta tendência à educação universal só pode ter como fim a barbárie" (BA/EE, prólogo, KSA 1.643). Em segundo lugar, o processo de ampliação deve necessariamente desembocar em um processo de erudição vazio e sem sentido. Nietzsche escreve:

[...] me parece que, por muitos outros lados diferentes, se entoa outra canção, desde logo menos sonora mas com não menos ênfase; a saber, a canção da redução da educação. Em todos ambientes eruditos só se sussurra ao ouvido esta canção: que com o ansiado uso do erudito ao serviço de sua ciência, sua formação se voltará cada vez mais casual e inverossímil (BA/EE, prólogo, KSA 1.643).

Todavia, a despeito do caráter ficcional da cultura alemã de sua época, cuja fundação ocorre sobre impulsos inaturais, há, segundo Nietzsche, uma tendência contrária que consumará, no futuro, uma radical transformação nos meios e métodos de ensino e, consequentemente, nas instituições de ensino. Nietzsche escreve: 
[...] se adivinhará a vitória algum dia a uma tendência educativa já existente, ainda que neste momento pudesse não ser querida, estimada, nem estar estendida. Mas ela vencerá, como creio com a maior das confianças, porque conta com a maior e mais poderosa das companheiras de aliança: a natureza (BA/EE, prólogo, KSA 1.643).

Na luta entre o natural e o inatural, isto é, entre as tendências de ampliação e redução dos meios formativos, ambas inaturais, e a exigência da própria natureza no tocante ao estreitamento e concentração dos meios de formação, a natureza, segundo Nietzsche, mostrar-se-á implacável.

Como contrapartida a esta tendência, encontra-se no ideal classicista de educação estética do homem um firme aporte teórico para as reflexões pedagógicas do jovem Nietzsche que, tal como seus predecessores, também acredita que a valorização da formação erudita e de caráter eminentemente teórico, tal como é praticada nas instituições de ensino alemãs de seu tempo, só pode contribuir para o caos e para a barbárie e jamais para a fundação de uma autêntica cultura. Num póstumo do verão de 1872 - início de 1873, o filósofo defenderá a hipótese de uma formação intuitiva em detrimento de uma formação essencialmente conceitual. Nietzsche escreve: "A formação não é necessariamente conceitual (begriffliche), mas sobretudo é intuitiva (anschauende)" (Nachlass/FP 1872 - 1873 19[298], KSA 7.511). Nesta perspectiva, Nietzsche entende que a educação de um povo para a formação deve ser entendida como um acostumar-se a bons modelos (gute Vorbilder) e a uma formação de necessidades nobres (Bildung edler Bedürfnisse) ${ }^{224}$.

De outro modo, em detrimento de uma formação abstrata e conceitual, Nietzsche sugere que o homem seja formado de maneira intuitiva por meio de uma educação estética (aesthetischer Erziehung) que consiste, em última análise, no contato com a arte dos clássicos antigos e dos clássicos alemães. Nesta acepção, Schiller, Goethe e Winckelmann são, para Nietzsche, modelos imprescindíveis para fazer da moderna educação alemã, uma educação eminentemente estética, o que significa dizer uma educação clássica:

Uma vez mais necessitamos desses mesmos guias, esses mesmos mestres, nossos clássicos alemães, para que o bater das asas de suas aspirações até a antiguidade leve também a nós...

${ }^{224}$ Cf. Nachlass/FP $1872-1873,19$ [299], KSA, 7.511. 
até a terra da nostalgia, a Grécia. Dessa relação - a única possível entre nossos clássicos e a educação clássica, não se vislumbra nada entre os velhos muros das escolas de bacharelado (BA/EE $\S 2$, KSA 1.672)

Contra as tendências modernas de formação, Nietzsche sugere uma pedagogia clássica pautada no estudo meticuloso da língua materna a partir dos escritos dos mestres clássicos alemães, como proposta de renovação dos meios educacionais na Alemanha que, naquele momento se encontrava absolutamente contaminada pelos impulsos modernos de ampliação e redução.

O símbolo maior desse tipo de formação ampliada e reduzida, segundo Nietzsche, é o jornalismo. Nietzsche escreve: "Efetivamente, no jornalismo (Journalistik) confluem as duas orientações; a ampliação e a redução da formação se dão aqui a mão. O jornal ocupa diretamente o lugar da formação (...)" (BA/EE §1 KSA 1.651). No âmbito da Alemanha moderna, a figura do jornalista, o "escravo do instante", substituiu o gênio da espécie, "o guia para todas as épocas, o que redime do instante" (BA/EE $\S 1$ KSA 1.651). Em outros termos, a filosofia e a arte foram substituídas pelo jornal e pelas novelas da moda, "cujo estilo leva em si o repugnante selo da barbárie educativa atual”(BA/EE §1 KSA 1.651).

No centro da crítica nietzschiana às instituições de formação alemãs de sua época está o problema da linguagem. Na avaliação de Nietzsche, as escolas de bacharelado alemãs deixaram de se comprometer com a formação do homem quando deixou de lado a rígida disciplina linguística ao desvalorizar e desfigurar a língua alemã. Para o filósofo, o aprendizado profundo da língua materna é uma condição, ou melhor, um "dever sagrado" para todo aquele que almeja ao ensino superior. Em tom de exortação, Nietzsche escreve: "Levar a sério vossa língua! Quem não consegue sentir nisso um dever sagrado, não terá em si nem sequer o gérmen para uma educação superior" (BA/EE $\S 2, \mathrm{KSA} 1.672)$. A maneira como a língua materna é tratada por um povo, afirma Nietzsche, diz muito acerca do seu apreço pela arte, bem como de sua aptidão para perseguir a cultura: "Se não chegais a tanto como a sentir asco ante certas palavras e certas distorções linguísticas de nosso condicionamento jornalístico então podeis deixar já de perseguir a cultura" (BA/EE $\S 2$, KSA 1.672).

A língua materna é o meio para realizar a verdadeira formação estética e moral do homem, bem como para construir uma autêntica cultura. Neste ponto de vista, Nietzsche atribui ao professor de alemão, no bacharelado, a incumbência de chamar a 
atenção dos alunos sobre as distorções linguísticas atuais em que os proíbe de utilizar, em seu vocabulário, tais distorções. Por outro lado, afirma Nietzsche, o mesmo professor deveria se utilizar dos autores clássicos alemães, percorrendo "linha a linha com quanto cuidado e rigor há que tomar as expressões quando no coração se tem o sentimento artístico correto e diante dos olhos a completa compreensibilidade de tudo o que escreve"(BA/EE $\S 2, \mathrm{KSA} 1.672)$. Segundo Nietzsche, este ensino rigoroso e exaustivo da língua alemã é um modo de separar os alunos mais bem dotados e aptos para o ensino superior, dos menos dotados, que desistirão no meio do caminho.

Porém, não é este o método que Nietzsche vê aplicado nas escolas de bacharelado alemãs. Nelas, o ensino rigoroso da língua materna a partir dos escritores clássicos fora substituído pelas características repugnantes da estética jornalística: "Na escola de bacharelado se imprimem as repugnantes características de nossa estética jornalística sobre os espíritos não formados dos adolescentes” (BA/EE § 2, KSA 1.672). Nestas escolas, tanto a língua alemã quanto os autores clássicos são banalizados pelos próprios professores. Para Nietzsche, estes são os responsáveis por disseminar um "grosseiro querer-mal-interpretar (Mißverstehen-wollen)" dos clássicos alemães" (BA/EE $\S 2, \mathrm{KSA} 1.672$ ), pois afirmam efetuar uma crítica estética quando o que fazem não é outra coisa senão uma "descarada barbárie” (BA/EE § 2, KSA 1.672).

O problema deste tipo de abordagem dos clássicos alemães não é apenas a banalização de suas obras e da própria língua materna, mas o falso sentimento de autonomia e autossuficiência que é produzido no aluno. Em disciplinas como "composição em alemão", incita-se a personalidade do aluno, ou seja, sua própria individualidade. Nietzsche escreve: "A composição em alemão é uma chamada ao indivíduo" (BA/EE $\S 2$, KSA 1.672). Ora, para Nietzsche, incitar a personalidade e originalidade do aluno na escrita é cometer um afrontamento diante da sagrada língua materna, e, neste sentido, é cometer "um pecado contra o espírito". (BA/EE $\S 2, \mathrm{KSA}$ 1.672).

Para Nietzsche, a originalidade e a personalidade são atributos que poucos homens maduros conseguem ter, portanto, incitar um adolescente a ter personalidade é um grande equívoco da educação alemã de sua época. Ao se considerar que um adolescente é capaz de compor um texto literário original e com personalidade, as instituições de formação também considera que este adolescente tem o direito de emitir opiniões e juízos próprios sobre os assuntos e as pessoas mais sérias. Para Nietzsche, 
tais instituições cometem um equívoco ao ensinar a autonomia quando deveria se ensinar a obediência. O filósofo alemão escreve:

[...] um ensino de verdade deveria reprimir com todos seus esforços as ridículas pretensões de uma autonomia de juízo e habituar o jovem a uma obediência estrita sob o cetro do gênio. Se está pressupondo a capacidade de representar o grande a uma idade em que qualquer frase, falada ou escrita, constitui um barbarismo (BA/EE $\S 2, \mathrm{KSA} 1.672)$.

Segundo Nietzsche, ao fomentar este tipo de formação as instituições de educação alemãs engendram uma situação perigosa para o futuro. Nietzsche enumera os males que o culto da personalidade e a autonomia de juízo na formação escolar geraram no ambiente literário e artístico alemão de sua época, estes são: a produção apressada e vaidosa, a completa falta de estilo, a ausência de caráter e refinamento na expressão, a perda de todo cânon estético, e, por fim, o prazer na anarquia e no caos. Estes são, em resumo, os traços literários que Nietzsche chama de jornalismo estético, ou, numa palavra, a barbárie. As instituições de formação alemãs, na acepção nietzschiana, ainda não possuem condições de implantar uma rigorosa e verdadeira formação, a que, segundo o filósofo, consiste, antes de tudo, na obediência e no hábito, especialmente no que se refere à língua materna.

Para o filósofo alemão, a tendência jornalística, ao prescindir dos ensinamentos dos grandes clássicos alemães, como Goethe, Schiller, Winckelmann e Lessing, se desviou da única via que conduz à autêntica formação clássica, a saber, a antiguidade, pois "toda a assim chamada educação clássica só tem um ponto de partida são e natural: o hábito artisticamente sério e rigoroso no uso da língua materna" (BA/EE $§ 2$, KSA 1.672). Nesta tarefa de formação, os clássicos são imprescindíveis, pois são como guias e mestres que conduzirão o aluno à verdadeira formação e à cultura.

O ensino da língua materna é uma chave de acesso ao espírito do povo. Dessarte, a concessão à cultura estrangeira, aos hábitos e aos estilos de outros povos é, segundo Nietzsche, o inimigo mais perigoso do espírito. Conservar a língua alemã é, em última análise, conservar a cultura e o espírito alemão. Nietzsche escreve: "Com força nos aferramos ao espírito alemão que se manifestou na Reforma alemã e na música alemã, e que se demonstrou na extraordinária audácia e rigor da filosofia alemã e na fidelidade recentemente provada do soldado alemão" (BA/EE $\S 2$, KSA 1.672). Entretanto, o que 
se promove nas instituições de formação alemãs não é o cultivo da língua materna, mas o seu extermínio.

Ao fomentar a extirpação da língua alemã, as instituições contribuem para o desaparecimento do próprio espírito alemão. Num póstumo de 1873, o filósofo escreve: “O alemão será logo um mosaico de palavras sem alma e com uma sintaxe europeia. Perdemos cada vez mais a linguagem e deveríamos saber que valor tem para nós - o alemão! Conseguimos um império alemão, no momento em que estamos a ponto de deixar de sermos alemães" (Nachlass/FP 1873, 27 [24], KSA 7.593). Próximo do pensamento de Burckhardt ${ }^{225}$, Nietzsche entende a linguagem como a expressão mais direta e ideal do espírito de um povo. Posto isto, ao dilapidar a língua alemã, o alemão aniquila aquilo que faz dele o que ele é: o espírito alemão. Nietzsche escreve:

Pois quem pecou contra a língua alemã profanou o mysterium de nossa germanidade: é somente ela que através de toda a mescla e as modificações das nacionalidades e dos costumes, como por milagre metafísico, se salvou a si mesma e desse modo salvou também o espírito alemão. É somente ela que garante ademais esse espírito para o futuro, sempre que não pereça ela mesma nas mãos perversas do "presente" (DS/Co Ext. I $\S 12$, KSA 1. 227).

Como produto da intuição humana, a linguagem guarda um potencial artístico e inconsciente de um povo que é ativado e ampliado pela atividade do estilista ou do orador. É, portanto, no aperfeiçoamento dos elementos artísticos inconscientes da

\footnotetext{
${ }^{225}$ Em Reflexões sobre a história, o historiador alemão Jacob Burckhardt afirma: “(...) os idiomas são a expressão mais direta, mais total e altamente específica do espírito dos povos, sua imagem ideal, a forma mais duradoura, na qual os povos depositam a substância da sua vida espiritual, encerrada principalmente nas palavras de seus grandes poetas e pensadores (BURCKHARDT, 1961, p. 63). É notória a influência das ideias do historiador da cultura Jacob Burckhardt no pensamento de Nietzsche, que participou como ouvinte das conferências que Burckhardt proferiu na Universidade da Basiléia das quais resultou a obra citada acima. Não obstante, não foi apenas a concepção burckhardtiana da linguagem que chamou a atenção do jovem filólogo, mas também a sua concepção de "Estado como obra de arte". Neste sentido, Burckhardt toma o estado como a uma criação artística consciente de um povo e não um acidente da história. Tal concepção é decisiva para a elaboração da concepção de cultura como unidade de estilo artístico de Nietzsche. Em A cultura do renascimento na Itália, Burckhardt escreve: "Assim como, em sua maioria, os Estados italianos constituíam obras de arte - ou seja, eram produto da reflexão, criações conscientes, embasadas em manifestos e bem calculados fundamentos -, também sua relação entre si e com o exterior tinha de ser uma obra de arte" (BURCKHARDT, 2009, p. 112). Sobre a influência de Burckhardt no pensamento de Nietzsche ver: ANDLER, Charles. Nietzsche, sa vie et sa pensée; GONTIER, Thierry. Nietzsche, Burckhardt et la 'question' de la Renaissance.Noesis, Paris, $\mathrm{n}^{\circ} 10$, p. 49 71, 2006; LARGE, Duncan. Nosso maior mestre: Nietzsche, Burckhardt e o conceito de cultura. Cadernos Nietzsche. São Paulo, n..9, p. 3-39, 2000. CHAVES, Ernani. Cultura e política: o jovem Nietzsche e Jacob Burckhardt. Cadernos Nietzsche. São Paulo, n.9, p. 41-66, 2000.
} 
língua, que as artes retórica e poética despertam no homem imagens inconscientes de sua coletividade ao mesmo tempo em que dissipa a representação ilusória da individuação. Então, ao dilapidar a língua alemã, o alemão aniquila aquilo que faz dele o que ele é; o próprio espírito alemão. Ao pensar a língua como o fundamento do espírito de um povo, Nietzsche não pode deixar de pensar o discurso filosófico sob a perspectiva da formação e da cultura, o que exige do filósofo alemão a tarefa de elaborar uma concepção de filosofia a partir da sua distinção em relação à ciência e à arte.

Entre os anos de 1872 e 1873, após a publicação de $O$ nascimento da tragédia, Nietzsche redige uma extensa série, notas destinadas a analisar a relação entre a filosofia e a cultura (Kultur). Como na primeira obra, o horizonte do pensamento nietzschiano continua a Grécia antiga, porém, em contraste com o que foi apresentado no primeiro livro, nestes escritos o jovem filólogo procura reavaliar o privilégio que outrora havia concedido à arte em detrimento da ciência no que tange o processo de construção da cultura grega, o que o leva a repensar a função e o lugar da filosofia nesta cultura $^{226}$. Nietzsche se põe a investigar a natureza do trabalho filosófico e a complexa relação que a filosofia estabelece com a ciência e com a arte, pois, se por um lado é ciência, a filosofia não é completamente arte; se de algum modo é arte, ela não pode ser uma ciência pura ${ }^{227}$.

Numa anotação póstuma dos cadernos do inverno de 1872- 1873, Nietzsche escreve: "Não é possível fundar uma cultura popular (Volkskultur) sobre a filosofia. Assim, a filosofia nunca pode ter, em relação com uma cultura (Kultur), uma importância fundamental, mas unicamente uma importância secundária. Qual é?" (Nachlass/FP 1872 - 1874, 23[14], KSA 7.439). Em outro fragmento do mesmo período, lê-se: “A filosofia não é para o povo e, portanto, não é base de uma cultura

\footnotetext{
${ }^{226}$ Nesta época, o contato com A história do materialismo de Friedrich Albert Lange parece ter despertado no jovem filólogo o gosto pelas ciências naturais e pelas filosofias positivistas, ao mesmo tempo em que o fez refutar a metafísica, inclusive a de Schopenhauer,passando a considerar dela apenas o valor edificante de uma "poesia conceitual". Esta guinada científica viria também a dissipar as convicções da metafísica de artista de procedência wagneriana, conforme proclamada em seu primeiro livro, e, segundo D'Iorio, atendia ao interesse do jovem Nietzsche de pensar o seu próprio lugar, como filósofo, em meio à futura cultura de Bayreuth. D'Iorio escreve: “Os fragmentos póstumos deste período procuram definir a função do gênio filosófico no seio da comunidade grega; isto é - traduzido numa linguagem contemporânea - de definir a posição de Nietzsche no seio da futura Kultur de Bayreuth. Uma Kultur mais e mais distante dos projetos de juventude de Wagner e bem diferente da comunidade de discípulos que, no ano anterior, teria participado da colocação da primeira pedra do teatro de Bayreuth" (D'IORIO, 1994, p. 14).

${ }^{227}$ Sobre a constituição ao mesmo tempo científica e artística da filosofia cf. os póstumos Nachlass/FP 19[62], KSA 7.439 e Nachlass/FP 23[8], KSA 7.540.
} 
(Kultur), por conseguinte, é apenas um instrumento (Werkzeug) de uma cultura (Kultur)" (Nachlass/FP 1872 - 1874, 23[45], KSA 7.558) ${ }^{228}$. A afirmação nietzschiana de que a filosofia, por não ser destinada para o povo, ocupa um lugar secundário em relação à cultura vista apenas como um instrumento a serviço de uma cultura, o que leva o homem a indagar sobre a natureza deste lugar, bem como o papel do filósofo no âmbito da cultura. Não obstante, é necessário que se compreenda previamente o que a filosofia é.

Em linhas gerais, a concepção de filosofia que é apresentada nos escritos póstumos de 1872 - 1873 é de inspiração grega. O contato com os filósofos antigos, de modo particular os pré-socráticos, foi determinante para que Nietzsche elaborasse a compreensão da filosofia como algo heterogêneo. Desse modo, a filosofia pré-socrática se apresenta, para Nietzsche, como uma pluralidade de interesses e perspectivas filosóficas distintas, sistemas e teorias filosóficas que ora se mostram próximos, ora, contraditórios $^{229}$. Tal complexidade faz da filosofia um importante instrumento para a cultura dos gregos na medida em que se constitui como um obstáculo ao dogmatismo rigoroso. No seguinte fragmento póstumo, Nietzsche esboça o modo de atuação da filosofia em relação à cultura grega em quatro pontos, cada um relacionado a um filósofo ou grupo de filósofos:

Domesticação do mítico. - Reforçar o sentido da verdade frente à poesia livre. Vis veritatis, ou fortalecer o conhecimento puro [Tales, Demócrito, Parmênides].

Domesticação do instinto do saber - ou reforçar o místicomítico, o artístico [Heráclito, Empédocles, Anaximandro]. Legislação do grande.

Destruição do dogmatismo rigoroso: a) na religião b) costumes c) ciência. Tendência cética.

Toda força [religião, mito, instinto de saber], quando é excessiva, tem efeitos bárbaros, imorais e embrutecedores, como domínio rígido [Sócrates].

\footnotetext{
${ }^{228}$ Sobre a relação do filósofo com o povo cf. Nachlass/FP 1872 - 1874, 23[14, 19].

${ }^{229} \mathrm{Em}$ suas Lições sobre os filósofos pré-platônicos, Nietzsche refutou a ideia tradicionalmente aceita em sua época de que a cronologia dos filósofos pré-socráticos poderia ser estipulada a partir de uma série de $\Delta \downarrow \alpha \delta o \chi \alpha i$, ou seja, de que é possível se organizar os filósofos em escolas e relacioná-los uns aos outros conforme uma ideia de sucessão entre mestre e discípulo. Contra esta ideia, o filósofo alemão propõe a tese de que a cronologia dos filósofosé “confirmada por sistemas" (Nachlass/FP 1872 - 1874, 23[41], KSA 7.557). Sobre a interpretação nietzschiana da cronologia dos filósofos pré-socráticos, cf. o criterioso estudo de Francesco Fronterrota que precede a tradução francesa das Lições sobre os filósofos préplatônicos: FRONTEROTTA, F. Chronologia philosophorum. In: NIETZSCHE, F. Les philosophes préplatoniciens. Trad. Olivier Sedeyn. Combas: éditions de l'éclat, 1994.
} 
Destruição da cega secularização [substituição da religião]. (Anaxágoras, Péricles). Tendência mística (Nachlass/FP 1872 - 1874, 23[14], KSA 7.439).

A despeito da pluralidade dos sistemas, Nietzsche concebe toda a filosofia présocrática sob a perspectiva de um jogo entre duas forças antagônicas: a arte e a ciência. Neste sentido, com Tales, Demócrito e Parmênides, a filosofia grega atuava de modo a reprimir o poder imagético do mito a partir de uma abordagem natural (Tales e Demócrito) e lógica (Parmênides), em suma, científica do cosmos. Por outro lado, sistemas filosóficos como o de Heráclito, Empédocles e Anaximandro produziam uma força contrária, de tendência artística e que atuava de modo a reprimir o instinto de saber do homem da ciência com o mito, instinto que posteriormente iria se assenhorear da filosofia com Sócrates.

Desse modo, no ambiente agonístico, ora científico ora artístico da filosofia présocrática, nenhuma das forças tende a se tornar excessiva e, por conseguinte, tirânica, fato que interdita o dogmatismo rigoroso e seus efeitos bárbaros sobre a cultura. Por isso, a afirmação nietzschiana de que, embora a filosofia não tenha uma importância fundamental para a cultura, uma vez que não se dirige ao povo, possui um determinado valor $(\text { Werth })^{230}$ na medida em que se impõe, ao mesmo tempo: “a) contra o dogmatismo das ciências; b) contra a confusão de imagens das religiões míticas na natureza; c) contra a confusão ética devido às religiões (Nachlass/FP 1872 - 1874, 23[45], KSA 7.558). Essencialmente antidogmática, a filosofia não pode criar uma cultura, logo, afirma Nietzsche, resta ao filósofo apenas a tarefa de "prepará-la; ou conservá-la; ou moderá-la”(Nachlass/FP 1872 - 1874, 23[14], KSA 7.439). Mas como pode a filosofia cumprir o papel ambíguo de ser ora um instrumento científico e esclarecedor, ora um instrumento artístico a serviço do mito?

"Na filosofia", afirma Nietzsche, "não há um elemento comum, ora é ciência, ora arte" (Nachlass/FP1872 - 1874, 23[8], KSA 7.540). Com efeito, o caráter não dogmático da filosofia está relacionado com a sua capacidade de atuar tanto como ciência quanto como arte, de modo que o que determinará a sua forma será o seu fim. Nietzsche escreve: "A essência (Wesen) da filosofia está de acordo com o seu fim"(Nachlass/FP 1872 - 1874, 23[45], KSA 7.558). Como um instrumento da cultura, sua finalidade deve ser consoante às necessidades da mesma. Dessa maneira, se for

\footnotetext{
${ }^{230}$ Sobre o valor da filosofia para a cultura, Cf. Nachlass/FP - $1872-1874,23[10]$, KSA 7.541.
} 
necessário, a filosofia se constituirá como ciência ao impedir que o dogmatismo religioso predomine numa determinada época - eis que surgem os sistemas de Tales, Demócrito e Parmênides. Caso contrário, ela se constituirá como arte e investirá contra o dogmatismo científico - é o momento de Heráclito, Empédocles e Anaximandro. Mas, se a filosofia é capaz de se moldar às necessidades da cultura é justo indagar em que medida possui uma existência em si mesma.

Para Nietzsche, a filosofia não existe em si mesma e, deste modo, pode assumir formas distintas de acordo com as necessidades da cultura, característica que faz dela um precioso instrumento para a sua preparação e preservação. Num fragmento póstumo do inverno de 1872-1873, Nietzsche escreve: “A existência de elementos preservadores que lutam durante um tempo. A filosofia, que não tem de modo algum existência em si mesma, é parte destes elementos. Colorida e preenchida conforme a época" (Nachlass/FP 1872 - 1874, 23[9], KSA 7.541). É por este motivo que a filosofia pode se apresentar entre os gregos da forma que se apresentou, ora como ciência ora como arte. Sem existência em si mesma, em que consiste a filosofia afinal?

Num fragmento póstumo destinado ao "livro do filósofo" (Philosophenbuch) ${ }^{231}$, Nietzsche demonstra certa perplexidade diante da constituição ambígua da filosofia:

Grande embaraço, se a filosofia é uma arte ou uma ciência. É uma arte em seus fins e em sua produção. Mas ela tem em comum com a ciência o meio, a representação em conceitos. É uma forma de arte poética. - Não se pode classificá-la: por isso devemos inventar uma nova espécie e caracterizála.(Nachlass/FP - 1872 - 1874, 19[62], KSA 7.439).

Como um tipo híbrido, a filosofia se constitui tanto como uma ciência quanto como arte, "é uma forma de arte poética". Contudo, sem ser estritamente nem uma coisa e nem outra, ela se torna inclassificável e carente de uma nova espécie para caracterizá-

\footnotetext{
${ }^{231}$ Dentre os póstumos redigidos nos anos de 1872 e 1873 encontram-se um grupo de notas destinadas à realização de um dos projetos inacabados de Nietzsche, o Livro do filósofo (Philosophenbuch). Embora tal empresa não tenha sido levada a termo, as anotações destinadas ao Livro acabaram sendo utilizadas em importantes escritos de sua produção juvenil. Tais notas compõem todo o grupo dezenove de fragmentos póstumos e, dispondo de uma grande diversidade temática, estes fragmentos serviram de base para a redação de importantes escritos deste período, como a série das quatro considerações extemporâneas, $A$ filosofia na época trágica dos gregos e Sobre a verdade e mentira no sentido extramoral, bemcomo para a preparação de cursos, como é o caso das lições sobre os filósofos pré-platônicos.
} 
la. Para isso, Nietzsche recorrerá a Lange e à sua caracterização da filosofia como poesia conceitual, bem como do filósofo como um poeta dos conceitos ${ }^{232}$.

Não obstante, tal definição traz mais problemas do que soluções, pois como conceber a ideia de uma poética conceitual sem negligenciar as diferenças que se interpõem entre a linguagem conceitual da ciência e da filosofia e a linguagem imagética da poesia? Em linhas gerais, a definição langeana da filosofia como poesia conceitual está assentada na ideia da constituição poética da linguagem, o que significa, para Lange, a linguagem se revela como uma proliferação de imagens que, a despeito de sua natureza estética se mostram úteis ao homem e à vida. Tal concepção vem ao encontro dos anseios teóricos do jovem Nietzsche que, como se viu no capítulo anterior, apareceram todas as formas discursivas, por conseguinte a filosofia e a ciência, como constitutivamente poéticas.

Volta-se, então, à distinção que o jovem Nietzsche faz entre a filosofia e a ciência, na qual afirma que tais discursos estão próximos no que tange os seus meios, isto é, sua natureza conceitual, porém, no que diz respeito à sua forma e aos seus fins a filosofia se distancia da ciência para se aproximar da $\operatorname{arte}^{233}$. Ora, se o discurso filosófico e o científico se utilizam dos mesmos meios, os conceitos, como compreender a divergência entre a sua forma e os seus fins? E em que sentido a forma e o fim do discurso filosófico estão próximos da arte? Em linhas gerais, é o posicionamento diante da verdade e do conhecimento o que determina a finalidade do discurso, e esta por sua vez determinará a sua forma.

\footnotetext{
${ }^{232} \mathrm{~A}$ designação do filósofo como um poeta dos conceitos e da filosofia como poesia conceitual é uma herança que o jovem Nietzsche recebe da teoria da linguagem de Friedrich A. Lange. Segundo Crawford (1988, p. 85), a concepção poética da linguagem, conforme exposta na teoria langeana da linguagem, exercerá uma forte influência sobre o jovem Nietzsche no que diz respeito as suas considerações acerca da relação entre a linguagem e a verdade. Crawford escreve: "Embora a linguagem não represente a verdade, ainda é uma necessidade básica para a preservação das espécies e, como tal, somos constrangidos a operar dentro de suas limitações. Em sua insistência de que a linguagem e a filosofia, até mesmo a ciência, em última análise, são imagens úteis, expressão poética, o que leva em direção ao ideal, Lange abre a possibilidade de um uso da linguagem figurativa, que teve uma grande influência sobre Nietzsche". Para Paolo D'Iorio (1994, p.35), Nietzsche utiliza a concepção langeana de poesia conceitual como um aporte teórico para a sua concepção do filósofo como criador de mitos para a construção e manutenção da cultura. D'Iorio escreve: “Ainda uma vez, Nietzsche faz apelo à concepção langeana do filósofo como poeta dos conceitos e tenta aproximar arte e filosofia enquanto forças produtoras de mitos indispensáveis para o surgimento de uma Kultur" (D’Iorio, 1994, p.35). Sobre a influência de Lange na teoria da linguagem do jovem Nietzsche cf. CRAWFORD, Claudia. The Beginnings of Nietzsche's Theory of Language. Berlin: de Gruyter, 1988. Sobre a concepção nietzschiana de filosofia como poesia conceitual cf. D'IORIO, P. La naissance de la philosophie enfantée par l'esprit scientifique. In: NIETZSCHE, F. Les philosophes préplatoniciens. Trad. Olivier Sedeyn. Combas: éditions de l'éclat, 1994.

${ }^{233}$ Nos referimos a Nachlass/FP $1872-1874,19[62]$, KSA 7.439
} 
O homem do conhecimnto (vernünftige Mensch), segundo Nietzsche, trabalha com a finalidade de produzir conhecimentos puros e verdadeiros, pois se encontra amparado em crenças vulgares: primeiramente, a crença de que existem coisas; em segundo lugar, a de que se pode conhecê-las e, finalmente, a de que se pode designá-las a partir de signos logicamente adequados, como visto nos conceitos. Deste modo, a superação da multiplicidade das representações pela unidade abstrata do conceito é o que torna possível o procedimento classificatório e generalizador sob o qual opera a ciência. Nietzsche escreve: "Fazer caso omisso do individual nos proporciona o conceito e com ele começa nosso conhecimento: com a classificação, com a formação de gêneros" (Nachlass/FP 1872 - 1874, 19[236], KSA 7.493).

Se o conceito é o ponto de partida para a produção de conhecimento puro e de verdades científicas, e se em sua origem é uma metáfora e jamais um signo que se encontra numa referência direta com a essência da coisa, qual é então o estatuto da verdade científica? Desprovida de fundamento ontológico, lógico ou epistemológico, a verdade científica, para Nietzsche, é uma tautologia que resulta da visada antropomórfica que o pesquisador dirige às coisas. Em Sobre verdade e mentira no sentido extra-moral, Nietzsche escreve:

Se forjo a definição de animal mamífero e em seguida declaro, depois de inspecionar um camelo: "vejam, um animal mamífero", com isso decerto uma verdade é trazida a luz, mas ela é de valor limitado, quero dizer, é cabalmente antropomórfica e não contém um único ponto que seja "verdadeiro em si", efetivo e universalmente válido, sem levar em conta o homem. $\mathrm{O}$ pesquisador dessas verdades procura, no fundo, apenas a metamorfose do mundo em homem, luta por um entendimento do mundo como uma coisa à semelhança do homem e conquista, no melhor dos casos, o sentimento de sua assimilação [...] Seu procedimento consiste em tomar o homem por medida de todas as coisas: no que, porém, parte do erro de acreditar que tem essas coisas imediatamente como objetos puros diante de si. Esquece, pois, as metáforas intuitivas de origem, como metáforas, e as toma pelas coisas mesmas (VM $\S 1, \mathrm{KSA} 1.875$, trad. RRTF).

Logo, a crença na existência de coisas passíveis de serem conhecidas e designadas revela o plano referencialista sobre o qual o homem da ciência constrói o seu discurso, bem como o caráter antropomórfico da sua concepção de verdade. (VM $§ 1$, KSA 1.875 , trad. RRTF). 
Enquanto se opõe ao método da ciência, a filosofia é apresentada por Nietzsche a partir de três pontos essenciais que são: "1. Convencida do antropomorfismo é cética; 2. Tem caráter seletivo e grandeza $(G r o ̈ ß e) ; 3$. Altaneira, abarca as coisas sob a ideia de unidade (...)" (Nachlass/FP 1872 - 1874, 23[45], KSA 7.558). No que diz respeito ao seu caráter cético, pode-se afirmar que o criticismo kantiano é sem dúvida o ponto de partida do ceticismo epistemológico a partir do qual o jovem Nietzsche identifica um ponto de inflexão no modo de se fazer filosofia. A impossibilidade de conhecer a coisaem-si, enfim, de acessar $a$ verdade, destitui o filósofo do compromisso com a produção de conhecimento puro e verdadeiro. Entretanto, o filósofo autêntico é o que reconhece esse momento como ponto de partida para o seu filosofar ${ }^{234}$.

Embora Nietzsche afirme que, ao filósofo iniciado na doutrina kantiana, não resta outra atitude em relação à verdade em si senão a cética, o ceticismo não pode ser a meta da filosofia. Numa nota póstuma, o filósofo escreve: "Aqui há de se criar um conceito: pois o ceticismo não é a meta" (Nachlass/FP 1872 - 1874, 19[35], KSA 7.427). O ceticismo, portanto, é o caminho através do qual a filosofia procura alcançar o seu propósito, logo é algo a ser superado: "Neste ceticismo nada pode viver [...] Nós devemos transcender este ceticismo, temos que esquecê-lo!" (Nachlass/FP 1872 - 1874, 19[125], KSA 7.459). Desfeita a ilusão da verdade, o filósofo nietzschiano já não crê na possibilidade da linguagem como correspondência entre os signos e as coisas, entre o conceito e $a$ verdade, doravante, resta ao filósofo a tarefa de criar conceitos e, por conseguinte, de criar verdades. Portanto, a filosofia se afasta da meta meramente especulativa da ciência para aproximar dos desígnios da arte.

Posto isto, em oposição ao modo dogmático de operar da ciência, que crê em tal correspondência, a verdade filosófica surge da construção artística de uma visão de mundo (Weltanschauung), haja vista a criação de conceitos no início deste procedimento. Nesta acepção, o discurso filosófico não deve estar voltado para os mesmos fins que o discurso da ciência, isto é, não cabe à filosofia enunciar conhecimentos puros e verdadeiros, pois, o que o filósofo empreende com os seus

\footnotetext{
${ }^{234}$ Para Nietzsche, Schopenhauer é umexemplo deste filósofo autêntico. Em sua Terceira Extemporânea, investigando as circunstâncias sob a qual aparece Schopenhauer, Nietzsche escreve: "Este foi o primeiro perigo cuja sombra cresceu Schopenhauer: o isolamento. O segundo se chama: o desespero da verdade. Este perigo acompanha todo pensador que segue seu caminho a partir da filosofia kantiana, pressupondo que seja um ser humano vigoroso e inteiro no sofrer e apetecer, e não uma ruidosa máquina de pensar e calcular" (SE/Co. Ext. III, §3, KSA 1.350).
} 
conceitos é mais uma construção de mundo (Weltconstruktion) do que a enunciação de um conhecimento puro e verdadeiro, eis porque a meta da filosofia está mais próxima da arte do que da ciência.

Em notas ao Livro do filósofo, Nietzsche descreve a natureza deste nos seguintes termos: "A descrição da natureza do filósofo. Ele conhece poetizando, e poetiza conhecendo" (Nachlass/FP 1872 - 1874, 19[62], KSA 7.439). No que diz respeito ao discurso filosófico, verdade e conhecimento são consequências do ato de poetizar, pois é poetizando que o filósofo cria e ao mesmo tempo, conhece a verdade sobre a qual poetiza. Mas como se dá este processo de construção poética da verdade na filosofia? E, uma vez que não se destina ao conhecimento puro, qual é a meta da filosofia? E em que medida se aproxima da arte?

Segundo Nietzsche, "O filosofo é uma autorrevelação do atelier (Werkstätte) da natureza - filósofo e artista falam dos segredos artesanais da natureza" (Nachlass/FP 1869 - 1874, 19[17], KSA 7.423). Conforme afirmado, o surgimento de um filósofo ou de um artista não é consequência do acaso e tampouco depende dos anseios e esforços de um sujeito que, mais que tudo, deseja se tornar um artista ou um filósofo. Em linhas gerais, eles são eventos necessários da natureza, representações do Uno-Primordial que carregam em si o telos da natureza. Em suas obras, nomeadamente a filosofia e a arte, representam os desígnios secretos da natureza e por isso são designados pelo filósofo alemão como os gênios (Genius) da espécie. Entendido como meta suprema da natureza que deseja efetivar-se na aparência prazenteira, gênio filosófico e gênio artístico, em suas representações, revelam os desígnios secretos da natureza.

Contudo, as representações do gênio filosófico e do gênio artístico extrapolam o âmbito da mera aparência ao se concretizar no modo de vida de um povo e ao se inscrever em sua praxis. No entanto, ainda que o gênio seja necessário para o povo, ele não é um produto da vontade do povo. Num dos fragmentos iniciais do Livro do filósofo, Nietzsche escreve: "Se há de mostrar como toda a vida de um povo reflete, de uma maneira impura e confusa, a imagem oferecida por seus gênios maiores: estes não são produtos da massa, mas a massa mostra sua repercussão" (Nachlass/FP 1869 1874, 19[1], KSA 7.417). É o gênio quem modela o povo ao instituir através de suas representações as normas, os costumes e hábitos, numa palavra, o ethos deste povo: "Também as forças éticas de uma nação se manifestam em seus gênios" (Nachlass/FP 1869 - 1874, 19[1], KSA 7.417). 
É notória a aproximação estabelecida entre a filosofia e a arte, produções que, na ótica do jovem Nietzsche, podem se reunir e até mesmo coincidir no que se refere a sua forma e finalidade edificante: "a uma boa altura tudo se reúne e coincide - as ideias do filósofo, as obras do artista e as boas ações” (Nachlass/FP 1869 - 1874, 19[1], KSA 7.417). Esta reunião, ademais, esta coincidência, revela o complexo fundo ao mesmo tempo estético e ético sobre o qual Nietzsche forja o seu conceito de filósofo, de inspiração eminentemente grega: "No mundo esplendido da arte - como filosofam eles!. ${ }^{235}$ (...) Seu juízo sobre a existência diz mais, porque tem ante si a plenitude relativa e todos os véus e ilusões da arte" (Nachlass/FP 1869 - 1874, 19[5], KSA 7.417).

Criadores de mundo, os filósofos pré-socráticos ultrapassam o plano do puro conhecimento teórico e científico da realidade na medida em que, de um ponto de vista estético, os seus sistemas filosóficos se revelam como construções de mundo que imprimem uma verdade e um sentido ético para a existência humana. O filósofo, em última análise, é necessário para o mundo, embora o universo não seja uma necessidade para o filósofo. Mas como compreender a relação entre a arte e filosofia? Ao partir da premissa de que "a uma boa altura tudo (arte, filosofia e moral) se reúne e coincide", pode-se concluir que tudo se identifica?

Não obstante a proximidade entre a filosofia e a arte, não se pode afirmar que há uma identidade entre estes conceitos, o que pode ser observado quando se leva em conta as distintas atribuições que Nietzsche confere ao filósofo e ao artista: "O filósofo deve conhecer o que se necessita e o artista deve criá-lo" (Nachlass/FP - 1872 - 1874, 19[23], KSA 7.423). Inspirado nos filósofos pré-socráticos, o filósofo nietzschiano "deve sentir de maneira mais intensa a dor universal: da mesma maneira que cada um dos antigos filósofos gregos expressam uma necessidade: aí, nesta falha, introduz o seu sistema. Constrói o seu mundo dentro dessa falha” (Nachlass/FP - 1872 - 1874, 19[23], KSA 7.423). A despeito da relação ambígua que o filósofo guarda com o artista, Nietzsche não deixa dúvidas sobre as competências de cada um, isto é, ao filósofo cabe o conhecimento das necessidades e ao artista a criação daquilo que se necessita.

\footnotetext{
${ }^{235}$ Aqui, Nietzsche alude aos filósofos gregos antigos, especificamente aos filósofos pré-socráticos.
} 
Contudo, o impulso do conhecimento e o da criação pode se reunir e coincidir num mesmo indivíduo - como é o caso dos filósofos pré-socráticos - quando se forma um novo tipo de filósofo, o que Nietzsche designa por artista-filósofo: "eu posso imaginar uma espécie completamente nova de artista-filósofo (Philosophen-Künstlers), o qual introduza naquele vazio uma obra de arte, como valor estético" (Nachlass/FP 1869 - 1874, 19[39], KSA 7.431). Então, inspirado nestes filósofos pré-platônicos, o jovem Nietzsche estabelece um tipo de relação agonística ${ }^{236}$ com a época trágica grega que acaba por influenciar decisivamente o modo de pensar a filosofia e o filósofo de seu tempo.

Resultado da relação entre o impulso criador e o do conhecimento, a filosofia, para Nietzsche, constitui-se em estreita relação tanto com a ciência quanto com a arte. Acerca da natureza desta relação, Nietzsche escreve:

Como se relaciona o gênio filosófico com a arte? Pouco há que aprender da relação direta. Devemos perguntar: o que é arte em sua filosofia? Obra de arte? O que é que fica quando seu sistema é destruído como ciência? Sem embargo, isso que permanece deve ser precisamente aquilo que reprime o impulso de saber, por conseguinte o artístico de uma filosofia (Nachlass/FP $1872-$ 1874, 19[45], KSA 7.433).

Dessa perspectiva, ainda que um sistema filosófico seja refutado enquanto ciência, de um ponto de vista estético perdura no tempo. Neste ponto de vista, seria impróprio invalidar um sistema filosófico como, por exemplo, o atomismo de Demócrito, ainda que dentro dos parâmetros da física atual sua teoria seja desprovida de qualquer valor científico. $\mathrm{O}$ que confere validade eterna à filosofia, portanto, não é a presença $d a$ verdade em seu discurso, mas da arte. Em resumo, se Demócrito pode

\footnotetext{
${ }^{236}$ No que concerne esta afirmação, estamos de acordo com o argumento que Paolo D'Iorio apresenta em $O$ nascimento da filosofia, texto introdutório à tradução francesa das lições nietzschianas sobre Osfilósofos pré-platônicos. Segundo este comentador, repetindo uma metodologia já utilizada em $O$ nascimento da tragédia, as lições nietzschianas sobre os filósofos pré-platônicos são frutos de uma relação agonística e paradigmática com o passado. D’Iorio escreve: "Nietzsche lança um olhar moderno sobre a antiguidade e observa o mundo contemporâneo com o olhar grego. A contaminação entre a filologia e as teorias estéticas wagnerianas engendraram o 'centauro' Nascimento da tragédia onde Ésquilo e Richard Wagner, a Kultur de Bayreuth e a cultura grega, se esclarecem reciprocamente. Desta vez, Nietzsche procura pôr em contato os fragmentos do pensamento pré-platônico com um conjunto de doutrinas e de correntes filosóficas (e científicas) de sua época. Nos dois casos, o estudo do passado assume um valor agonístico e paradigmático face ao presente" (D'IORIO, 1994, p.17).
} 
construir uma verdade enquanto uma visão de mundo atemporal foi porque neste filósofo o impulso do saber foi domesticado pelo artístico. Chega-se, portanto, à segunda característica da filosofia, a capacidade seletiva e a grandeza.

Com efeito, o impulso artístico, no filósofo, tende a inibir e dominar o do conhecimento (Erkenntnißtrieb): "O conteúdo da arte coincide com o da filosofia antiga, mas vemos utilizadas como filosofia as partes isoladas constitutivas da arte, para reprimir o impulso do conhecimento"(Nachlass/FP 1869 - 1874, 19[41], KSA 7.432). A rigor, a atuação desse impulso estético permite ao filósofo distinguir e selecionar aquilo que merece ser conhecido, o que faz da filosofia um tipo de conhecimento elevado: "Agora nos foi dada uma forma superior de vida, um transfundo artístico - também agora a consequência imediata é um impulso de conhecimento seletivo, isto é, a filosofia" (Nachlass/FP 1869 - 1874, 19[21], KSA 7.422). Distinta da ciência, cujo impulso do conhecimento se lança, sem critério ou meta, sobre qualquer coisa que possa ser conhecida, a filosofia pode selecionar aquilo que conhece.

A capacidade seletiva é o que está na base da distinção nietzschiana entre

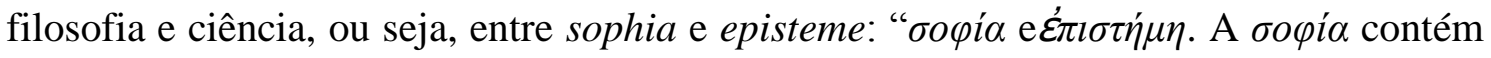
em si o seletivo, o que possui gosto: enquanto a ciência, que carece de semelhante gosto refinado, se lança sobre tudo o que é digno de ser sabido" (Nachlass/FP 1872 - 1874,

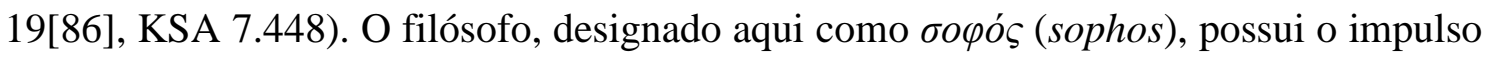
cognoscitivo seletivo e moderado, tem o gosto apurado ${ }^{237}$ e, dessa forma, não lhe apetece o conhecimento desesperado e sem meta. No que tange o homem da ciência, "sem essa discriminação e esse refinamento do gosto, precipita-se sobre tudo o que é possível saber, na cega avidez de querer conhecer a todo preço" (PHG/FT §3, KSA $1.813)$.

É certo que o filósofo e o homem da ciência atuam a partir do mesmo impulso do conhecimento, o que faz com que a filosofia e a ciência pensem do mesmo modo: "Não existe nenhuma filosofia especial, separada da ciência: em um caso como em outro se pensa do mesmo modo" (Nachlass/FP 1872 - 1874, 19[76], KSA 7.444).

\footnotetext{
${ }^{237}$ É importante notar que, de um ponto de vista semântico o termo "filosofia" provavelmente não existia na época dos pré-platônicos com o sentido que veio a assumir a partir dos escritos de Platão. Daí o destaque que Nietzsche confere a outro termo, mais antigo e vigente já na época de Tales: sophos. Em $A$ filosofia na época trágica dos gregos, Nietzsche escreve: "A palavra grega que designa o "sábio" prendese etimologicamente a sapio, eu saboreio, sapiens, o degustador, sisyphos, o homem do gosto mais apurado; um apurado degustar e escolher, um significativo discernimento constitui, pois, segundo a consciência do povo, a arte própria do filósofo" (PHG/FT §3, KSA 1.813).
} 
Quando Nietzsche afirma ser a capacidade seletiva o que distingue a filosofia da ciência, o filósofo alemão se refere ao poder que a filosofia tem de eleger aquilo que é digno de ser conhecido, isto é, de tratar de assuntos grandes: “O pensamento filosófico é especificamente da mesma natureza que o pensamento científico, mas se refere a coisas e a assuntos grandes" (Nachlass/FP 1872 - 1874, 19[83], KSA 7.447). Esta capacidade da filosofia de selecionar os assuntos grandes só é possível quando se inibe e seleciona o impulso do conhecimento. Mas em que consiste o conceito nietzschiano de grande $($ Größe) ?

"O conceito de grande", afirma Nietzsche, "é, sem embargo, um conceito variável, em parte estético, em parte moral. É uma repressão do impulso de conhecimento. Nisso reside seu significado para a cultura” (Nachlass/FP 1872 - 1874, 19[83], KSA 7.447). O que está em jogo, no limite, é a possibilidade de que, através do seu impulso artístico, o filósofo possa reprimir o impulso do conhecimento e sua vontade desenfreada de saber enquanto o orienta para os fins elevados da existência, isto é, aqueles que contribuam de alguma forma para a vida: "O valor da filosofia nesta repressão não está na esfera cognitiva, mas na esfera da vida (...)” (Nachlass/FP 1872 1874, 19[45], KSA 7.433).

Nietzsche aposta na arte como único meio de refrear a ciência de seu tempo: "A domesticação da ciência se consegue agora somente através da arte. Se trata de juízos de valor sobre o saber e a erudição" (Nachlass/FP 1872 - 1874, 19[36], KSA 7.428). Nesta lógica, o ataque que o jovem Nietzsche empreende ao cientificismo dominante na Alemanha moderna não tem por objetivo a aniquilação da ciência, mas sim o seu controle e submissão à filosofia: "não se trata de destruir a ciência, mas de dominá-la" (Nachlass/FP 1872 - 1874, 19[24], KSA 7.424). Desse modo, assim como no passado o saber científico foi um instrumento necessário e eficaz para reprimir a fé e o dogmatismo religioso, o homem moderno necessita da arte para refrear o impulso cognoscitivo desmedido e fortalecer os seus impulsos éticos e estéticos: "A história e as ciências naturais foram necessárias frente à idade média: o saber frente à fé. Nós dirigimos hoje a arte contra o saber: volta à vida! Repressão do impulso do conhecimento! Fortalecimento dos instintos morais e estéticos!” (Nachlass/FP 1872 1874, 19[38], KSA 7.430).

Nesta acepção, é o impulso artístico o que permite ao filósofo dominar e direcionar o pathos da verdade, isto é, o seu impulso à verdade para as necessidades da vida. Assim, a filosofia, na perspectiva do jovem Nietzsche, deve ser um conhecimento 
controlado e dirigido para assuntos grandes, de modo especial àqueles que dizem respeito à formação estética e moral do homem. Quando isso não acontece, ou seja, quando o impulso do conhecimento não é controlado, a filosofia se reduz a um conhecimento sem critério e sem meta como o conhecimento científico, cuja principal característica é o anseio desenfreado pelo saber: "O filósofo do conhecimento desesperado se consumará em uma ciência cega: o saber a todo custo" (Nachlass/FP 1872 - 1874, 19[38], KSA 7.430). Segundo Nietzsche, o impulso de conhecimento indiscriminado e desmedido, como o da ciência, é "um sinal de que a vida envelheceu (...)" (Nachlass/FP $1869-1874,19[21]$, KSA 7.422).

Dessa maneira, enquanto na ciência o pathos da verdade resulta numa busca cega e improfícua $d a$ verdade, no filósofo esse sentimento produz outra relação com verdade. Neste, graças à intervenção do impulso artístico, o pathos da verdade se revela num desejo profundo de, através da arte, dar à luz uma verdade eterna. É neste sentido que o filósofo alemão escreve: "lutar por uma verdade e lutar pela verdade são coisas completamente distintas" (Nachlass/FP 1872 - 1874, 19[106], KSA 7.454). O desejo de criar uma verdade permanente é uma tarefa completamente distinta da de buscar incessantemente $a$ verdade. Sobre essa nova tarefa do filósofo, Nietzsche escreve:

O filósofo busca também agora, no âmbito em que dominam as religiões, o 'efetivo' (Wirkliche), o que permanece, no sentimento do eterno jogo mítico da mentira. Ele quer uma verdade que permaneça. Para tanto, estende a novos âmbitos a necessidade de convenções sólidas de verdade (Nachlass/FP 1872 - 1874, 19[230], KSA 7.492).

Tal como o mito e a religião, a filosofia também anseia por uma verdade que permaneça no tempo, que não está à espera do filósofo e por isso tem de ser forjada por si mesmo no jogo constante com a ilusão e a mentira. Não é a aniquilação da verdade o que o filósofo pretende, mas sua reconstrução sobre uma nova base, a arte. Inicia-se, então, a terceira característica da filosofia anunciada por Nietzsche: a maneira de abarcar a multiplicidade das coisas sob a ideia de unidade.

Em Sobre o pathos da verdade, escrito póstumo redigido no ano de 1872, Nietzsche apresenta o problema da verdade em conexão com o problema da cultura 
$(\text { Kultur })^{238}$. Para Nietzsche, é a partir de um impulso artístico que o filósofo, num momento de iluminação, domina a multiplicidade do vir-a-ser e cria um mundo como uma totalidade: "Estes são os momentos das iluminações repentinas, nas que o homem estende seu braço numa atitude imperativa como na criação do mundo, retirando luz de si mesmo e irradiando-a ao seu redor"(CV/CP Sobre o pathos da verdade $\S 1$, KSA 1.755). O mundo criado pelo filósofo é uma verdade que ilumina e enobrece os sentimentos estéticos e morais do homem, logo, uma verdade que o filósofo considera digna de ser eternizada: "Em seguida, ele - o filósofo - rompeu com a feliz certeza de que não se pode privar a posteridade de que aquilo que lhe havia elevado e arrebatado até o mais distante, ou seja, à altura deste sentimento único (CV/CP Sobre o pathos da verdade $\$ 1, \mathrm{KSA} 1.755)$.

Frente à multiplicidade do vir-a-ser, o homem necessita crer em uma verdade que permaneça. Por isso, o homem necessita do filósofo, pois tem necessidade eterna da verdade. Nietzsche escreve: "Posto que o mundo necessita eternamente da verdade, tem a eterna necessidade de Heráclito, ainda que Heráclito não necessite do mundo" (CV/CP Sobre o pathos da verdade $\S 1$, KSA 1.755). Como legítimo construtor de mundo, o filósofo é o portador da verdade: "O filósofo tem a verdade; a roda do tempo pode rodar até onde queira, mas nunca poderá escapar da verdade" (CV/CP Sobre o pathos da verdade $§ 1, \mathrm{KSA} 1.755)$.

Dessarte, a eterna busca pela verdade impele o homem a eternizar o momento grande e único de claridade que só o filósofo lhe proporciona, enquanto exige que se conserve essa verdade única que o eleva. Segundo Nietzsche, o imperativo do homem moral diz: "o que existiu uma vez para perpetuar de uma maneira mais bela o conceito de 'homem', deve também subsistir eternamente" (CV/CP Sobre o pathos da verdade $\S 1$, KSA 1.755). Destarte, o filósofo surge como uma garantia do futuro da humanidade uma vez que, como afirma Nietzsche, "a humanidade necessita dele para o futuro" (CV/CP Sobre o pathos da verdade §1, KSA 1.755). O grande (Größe) momento criado

\footnotetext{
${ }^{238}$ Sobre o pathos da verdade é o primeiro dos Cinco prefácios para cinco livros não escritos, escrito póstumo dedicado e enviado a Cosima Wagner que o receberá com certo receio, afirmando que, a despeito dos sentimentos profundos ali expressados, o texto se apresenta como uma "busca torpe". Em uma anotação de seu Diário de 3 de janeiro, Cosima Wagner escreve: "O manuscrito do Pr. N. tampouco alegra nosso espírito; agora se expressa em ocasiões com uma torpe busca, contudo são sempre sentimentos de uma grande profundidade. Desejaríamos que ele se ocupasse principalmente de temas gregos". Os temas apresentados em Sobre o pathos da verdade são temas que serão tratados por Nietzsche em escritos posteriores, como o problema verdade como correspondência em Sobre verdade e mentira no sentido extra-moral e o problema da cultura (Kultur) nas Extemporâneas.
} 
por ele, sua própria filosofia, é o que permanece sobre o desaparecer e perecer de todas as coisas, pois através desta verdade eterna o presente é anelado ao passado e ao futuro. Num fragmento dedicado ao Livro do filósofo, Nietzsche escreve: "A filosofia tem que se manter firme através dos séculos nos altos cumes do espírito: e reter neles a fecundidade eterna de tudo o que é grande" (Nachlass/FP 1872 - 1874, 19[33], KSA 7.426).

Com o passar dos séculos, a filosofia se constitui como um instrumento valioso da cultura $(\text { Kultur })^{239}$. Nietzsche escreve: “A ideia fundamental de cultura é que os grandes momentos formem uma cadeia, que eles, como uma cordilheira de montanhas, unam a humanidade através de milênios, que para mim o maior de uma época passada seja também grande (Größe) (...)”(CV/CP Sobre o pathos da verdade §1, KSA 1.755). Dessa maneira, o grande é aquilo que não está susceptível à temporalidade e, por conseguinte, a eternidade é a essência do conceito nietzschiano de grandeza. A exigência da humanidade para que se eternize o momento grande é o início da luta da cultura: "Com a exigência de que a grandeza deve ser eterna, se inicia a terrível luta da cultura" (CV/CP Sobre o pathos da verdade $§ 1$, KSA 1.755).

$\mathrm{Na}$ medida em que imprime o selo do grande no passado, no presente e no futuro, o filósofo é capaz de reduzir a pluralidade das ações humanas a uma unidade coesa, de modo que aquilo considerado como grande se eternize em cada manifestação do homem quando a eleva moralmente. Logo, o filósofo, para Nietzsche, opera como um legislador da grandeza, isto é, um nomeador das coisas: "“isso é grande' diz o filósofo, e com isso eleva o homem. Começa com a legislação da moral: 'isso é grande' (...)” (Nachlass/FP 1872 - 1874, 19[33], KSA 7.426). Legisladores do grande, os filósofos são, para Nietzsche, homens raros e exemplares, que "deixam atrás de si uma doutrina, segundo a qual esta existência é vivida da maneira mais bela por aquele que não lhe dá muita importância”(CV/CP Sobre o pathos da verdade §1, KSA 1.755).

É nesta sequência que, ainda que não atribua à filosofia uma importância fundamental para a cultura, Nietzsche a considera um valioso instrumento para a sua preparação ${ }^{240}$, pois, ao criarem visões de mundo grandes e eternas, os filósofos

\footnotetext{
${ }^{239}$ Em uma anotação para o Livro do filósofo, Nietzsche assume como sua tarefa "compreender o íntimo nexo e a necessidade de toda verdadeira cultura. O remédio protetor e terapêutico de uma cultura, a relação da mesma com o gênio do povo" (Nachlass/FP 1872 - 1874, 19[33], KSA 7.426).

${ }^{240}$ Cf. Nachlass/FP $1872-1874,23[14]$, KSA 7.544
} 
fornecem os subsídios necessários para a realização da cultura. Em um póstumo do inverno de 1872-1873, o filósofo escreve: “A cultura só pode partir da significação central de uma arte ou de uma obra de arte. A filosofia preparará involuntariamente a visão de mundo dessa obra de arte"(Nachlass/FP 1872 - 1874, 23[14], KSA 7.544). E em passagens do Livro do filósofo, afirma: "A consequência de todo mundo artístico grande é uma cultura" (Nachlass/FP 1872 - 1874, 19[33], KSA 7.426). Nesta acepção, pode-se afirmar que é somente através da criação artística que a cultura, como unidade de estilo artístico em todas as manifestações da vida de um povo ${ }^{241}$, pode ser instituída. Não obstante, é somente através da visão de mundo criada pelo filósofo que o artista pode conceber a tal obra. Dessa forma, no que diz respeito aos seus fins edificantes, a filosofia se aproxima da arte uma vez que se encontra a serviço da cultura. Entretanto, é preciso ainda investigar em que sentido a filosofia se aproxima da arte no aspecto formal.

Se Nietzsche aproxima a filosofia da arte no tocante a sua forma é por entender que a filosofia é antes de tudo uma criação poético-conceitual e que o filósofo é um poeta dos conceitos. É neste sentido que se deve entender a descrição nietzschiana de Schopenhauer: "Como antítese de Kant, Schopenhauer é o poeta; como antítese de Goethe, é o filósofo" (Nachlass/FP 1868 - 1869, 75[20], KWGI. 5. 241). Para o jovem Nietzsche, o filósofo que na Alemanha de sua época melhor representa esta concepção de filosofia é Schopenhauer: "Esta é a época de Schopenhauer; um pessimismo são que tem no fundo o ideal de uma seriedade viril, de uma aversão até o vazio e privado de substância, e de uma inclinação até o saudável e simples" (Nachlass/FP 1868 - 1869, 75[20], KWGI. 5. 241).

Schopenhauer é uma exceção entre os escritores alemães ${ }^{242}$ de seu tempo. A linguagem simples e substancial em que transcreve o seu sóbrio pessimismo são aspectos que fazem da sua filosofia da vontade um evento sem paralelo na cena filosófica da Alemanha de sua época. Nesse ambiente cultural, em que a utilização arbitrária da língua alemã pelos escritores modernos desencadeia um processo de

\footnotetext{
${ }^{241}$ Esta é a definição nietzschiana de cultura expressa na PrimeiraExtemporânea.Cf. DS/Co I $§ 2$.

${ }^{242} \mathrm{Um}$ filósofo cometa, cf. PHG/FT $§ 2, \mathrm{KSA} 1.809$.
} 
fragmentação da linguagem e caos estilístico ${ }^{243}$, Nietzsche encontra na escrita schopenhaueriana a simplicidade de estilo que própria do gênio ${ }^{244}$.

Com efeito, o estilo é um fator determinante na avaliação que o jovem Nietzsche faz acerca do filósofo de seu tempo e, de modo particular, de Schopenhauer. Primeiramente, é um critério segundo o qual o autor de $O$ nascimento da tragédia opõe o mestre pessimista aos seus pares: "há nele estilo: enquanto a maioria dos filósofos não o tem [...]"(Nachlass/FP 1868 - 1869, 75[20], KWGI. 5. 241).. E ainda: "É sumamente notável o fato de que Schopenhauer escreva de uma maneira bela! Também sua vida tem mais estilo que a dos docentes universitários - mas os ambientes em que ele se move são ambientes raquíticos! (Nachlass/FP 1872 - 1874, 19[22], KSA 7.423).

Ora, o que Nietzsche acha notável, em primeiro lugar, é o fato de Schopenhauer escrever com estilo, isto é, de uma "maneira bela". Portanto, sua escrita não está a serviço $d a$ verdade, mas da beleza ${ }^{245}$, o que pode provocar um sentimento estético no leitor. Notável também é o fato de que a vida de Schopenhauer também tem mais estilo do que a dos seus pares. Pode-se afirmar então que, no que diz respeito à escrita ou à vida, aquilo que tem mais estilo tem mais beleza. Ainda no ímpeto de distinguir Schopenhauer dos filósofos de seu tempo, Nietzsche afirma: "no que diz respeito à Kant, é ingênuo (naïf) e clássico (klassisch)" (Nachlass/FP 1868 - 1869, 75[20], KWGI. 5. 241), é "o filósofo de uma reanimada classicidade, de uma grecidade alemã" (Nachlass/FP 1868 - 1869, 75[20], KWGI. 5. 241).

Mais do que um modelo artístico da antiguidade, o clássico, para Nietzsche, relaciona-se com a ideia de totalidade ${ }^{246}$. Um escritor clássico, portanto, é aquele cuja potência artística é capaz de criar uma obra enquanto um todo coeso para o qual é necessário ser simples e ingênuo. Como artista ingênuo ${ }^{247}$, deve ordenar o caos dos elementos linguísticos e rítmicos ao impor à obra uma unidade de estilo artístico. Simplicidade de estilo (Simplicität des Stil) e ingenuidade são as principais

\footnotetext{
${ }^{243} \mathrm{Cf}$. DS/CO ext.I § 1, KSA 1.159.

${ }^{244} \mathrm{Cf}$. DS/CO ext.I $\S 10$, KSA 1.216.

${ }^{245} \mathrm{~A}$ noção de beleza, no jovem Nietzsche, se aproxima da acepção do classicismo alemão, de modo particular de Winckelmann, que considerava, bela uma obra cujas partes se harmonizem num todo. No entanto, se afasta destes autores na medida em que não acredita que a arte bela seja o produto de um sujeito, mas como vimos no capítulo anterior, consiste num impulso da vontade.

${ }^{246} \mathrm{Em}$ sua Primeira Extemporâneas, Nietzsche tende a identificar o escritor clássico (klassischer Schriftsteller) a partir desta capacidade para compor um todo. Questionando a possibilidade de David Strauss ser um escritor clássico ou não, o filósofo escreve: "Assim, pois, o que nós perguntamos é se Strauss tem a força artística para traçar um todo, um totum ponere" (Cf. DS/Co. Ext. I § 9, KSA 1.208).

${ }^{247}$ Sobre o conceito de ingênuo (naïf), cf. nota 167.
} 
características do escritor clássico, bem como os indícios de sua genialidade, haja vista que o gênio é o único capaz de se expressar de maneira simples, natural e ingênua ${ }^{248}$.

Com efeito, Schopenhauer é, para o jovem Nietzsche, o gênio ingênuo de seu tempo. Na sua escrita, afirma Nietzsche "se pode reconhecer com frequência onde estabelece um novo começo, onde adquire um genial impulso" (Nachlass/FP 1868 1869, 75[20], KWGI. 5. 241). A ingenuidade e a simplicidade de estilo do autor de $O$ mundo como vontade e representação, é relacionada com a capacidade genial de engendrar sempre um novo começo, um novo mundo, uma nova criação artística. Sobre este impulso criador, Nietzsche escreve: "também os juízos de Schopenhauer tem uma originalidade clássica: grande parte do patrimônio universal, já deteriorado e esmagado, reaparece nele como uma nova criação. Tem obtido brilho de moedas depreciadas e revelado seu áureo esplendor" (Nachlass/FP 1868 - 1869, 75[20], KWGI. 5. 241).

O poder edificador ou formador de um filósofo, portanto, encontra-se diretamente relacionado à dimensão estética de sua escrita, que é o resultado imediato da sua ingenuidade e classicidade, isto é, da simplicidade de seu estilo e da força para criar uma plenitude a partir do caos um mundo. É pela sua simplicidade de estilo que Schopenhauer se distingue de todos os seus pares, um clássico entre os modernos, enfim, belo e saudável num ambiente cultural degenerado. Sua escrita é a escrita de outros tempos; sua verdade é a verdade eterna do gênio que deve ser conduzida à posteridade e eternizada pela humanidade. Nesta acepção, Nietzsche escreve:

Schopenhauer é o filósofo de uma Alemanha regenerada; por isso estava tão acima de seu tempo, tempo que agora começa a se aproximar. É mais sóbrio que sua época e, ao mesmo tempo, mais são, ainda que também mais belo e ideal, sobretudo mais verdadeiro (Nachlass/FP 1868 - 1869, 75[20], KWGI. 5. 241).

Ser sóbrio, sadio e belo são os indícios da saúde e do caráter, qualidades que se traduzem em ser simples e uno no seu estilo. A "classicidade" se revela como uma expressão da potência para estabelecer a medida e a proporção ao caos. Deste modo, a grandiosidade de um sistema filosófico é sempre derivada do caráter grande (grossen Character) do gênio, pois, se a escrita tem unidade de estilo é porque na vida ele

\footnotetext{
${ }^{248}$ Cf. DS/Co. Ext. I §10, KSA 1.216.
} 
também o tem. Dessa forma, o potencial formador da linguagem não emana do desenvolvimento lógico dos argumentos, mas do contato afetivo com o caráter que está configurado no estilo e na linguagem. Em um póstumo intitulado Sobre a linguagem e o estilo de Schopenhauer, Nietzsche escreve:

Aquela força vigorosa e viril, e sua linguagem que alcança a profunda intuição artística até a altura solar da mística, com a qual nosso filósofo "atual” [philosophischer „,Gegenwärtiger"] busca designá-las mediante o termo depreciável de "elegância". Ah, estes "elegantes"! Falta-lhes completamente esse pathos moral [sittliche Pathos] e esse tom uniformemente elevado. (Nachlass/FP 1869 - 1872, 7[159], KSA 7.200).

Ao buscar a eterna grandeza e a profunda intuição artística, a força e virilidade do estilo de Schopenhauer se opõem radicalmente à "elegância" do filósofo "atual". Seu tom uniformemente elevado revela o pathos moral e o caráter legislador de sua filosofia que busca no grande a elevação do homem. É neste sentido que Nietzsche o tomará como educador. Não obstante, da perspectiva nietzschiana, educar não consiste em doutrinar ou instruir, mas em libertar o homem para que este encontre o caminho para o cultivo de si mesmo, o que significa dizer para a formação.

Dessa maneira, ao fomentar o cultivo de si mesmo, a filosofia, para Nietzsche, mostra-se como um preâmbulo para a formação. Em tom confessional, Nietzsche afirma ter desde cedo buscado no filósofo o educador ideal. Na filosofia de Schopenhauer, Nietzsche diz ter tido pela primeira vez o pressentimento de ter encontrado este filósofo educador $^{249}$. Mas é na naturalidade do estilo de Schopenhauer que Nietzsche constata a honestidade, a serenidade e a constância do seu caráter exemplar, bem como o poder formador de sua filosofia:

$\mathrm{Eu}$ não descrevo outra coisa que a primeira impressão de certo modo fisiológica que Schopenhauer produziu em mim, essa mágica difusão da força íntima de uma criatura da natureza sobre outra que acontece com o primeiro e mais leve dos contatos; e se agora analiso retrospectivamente essa impressão, a encontro composta em três elementos, da impressão de sua honestidade, da sua serenidade e da sua constância.

\footnotetext{
${ }^{249}$ Cf. SE/Co. Ext. III § 2, KSA 1.341.
} 
Schopenhauer é honesto porque fala a si mesmo e porque escreve para si mesmo, é sereno, porque mediante o pensamento venceu o mais difícil, e é constante, porque tem a obrigação de ser $\operatorname{assim}($ Cf. SE/Co. Ext. III $§ 2$, KSA 1.337).

Como expressão de seu caráter simples e ingênuo, o estilo de Schopenhauer se revela como o princípio formador de sua filosofia, uma vez que se mostra como o exemplo a partir do qual o seu leitor formará o seu próprio caráter. Nesta afirmação, a filosofia de Schopenhauer, segundo Nietzsche, não pode ser entendida da perspectiva teórica, mas estética e ética. Eis o motivo de seu estilo.

Quando se leva em conta um póstumo da década de 1870, em que Nietzsche sugere que o valor do estilo, para a filosofia, depende do que se exige do filósofo, isto é, se o fim da filosofia é o puro conhecimento científico e a erudição, ou se sua tarefa é a formação do homem ${ }^{250}$. Pode-se, então, propor o seguinte questionamento: qual é, para Nietzsche, o estilo apropriado para o discurso filosófico? Com efeito, se a meta da filosofia, para Nietzsche, não é o conhecimento puro, mas, como se procurou mostrar, é a edificação do homem, prescinde do estilo obrigatório e habitual da ciência, cujo poder semântico das metáforas já se encontra inibido pelo uso e pelo hábito. Na medida em que Nietzsche pensa em uma formação intuitiva, o estilo do discurso filosófico deve revelar sua potência artística, isto é, a sua capacidade de produzir no leitor um efeito estético e, neste sentido, ele não pode ser destituído dos elementos retóricos da linguagem.

É na escrita inabitual da poesia que, segundo Nietzsche, a filosofia deve encontrar mais estímulos: "Agora bem, o raro e o inabitual estão mais plenos de estímulos - a mentira é percebida como um estímulo. Poesia" (Nachlass/FP 1872 1874, 19[228], KSA 7.490). Nos arranjos raros e nas metáforas não habituais, a escrita poética se mostra como um instrumento eficaz para a comunicação da verdade filosófica que, como se vê, não consiste em comunicar uma verdade a ser capturada pelo intelecto, mas na comunicação afetiva para visualizar o mundo artisticamente. O estilo, portanto, é o elemento que torna o discurso filosófico pleno de estímulos, destarte apropriado para realizar a tarefa da educação estética do homem.

\footnotetext{
${ }^{250}$ Nachlass/FP 1869, 75[20], KWG I. 5. 241.
} 
Tal como o artista, o filósofo deve ser um estilista, isto é, pensa a filosofia não como um conjunto de ideias abstratas, mas como fizeram os filósofos gregos préplatônicos, expressa uma visão de mundo grande e nobre através de uma forma estética que também possua grandeza e nobreza. É a partir desta forma, enfim, deste estilo, que o filósofo produz no indivíduo um efeito transfigurador ${ }^{251}$, o que significa aperfeiçoar a sua natureza de modo a fazer de si mesmo um todo harmônico e coeso. Por intermédio do estilo próprio, o filósofo realiza a sua tarefa educadora que, da perspectiva do jovem Nietzsche, consiste em remodelar (umbilden) o ser humano inteiro em um sistema solar e planetário dotados de vivos movimentos ${ }^{252}$. Uma vez que a ideia nietzschiana de formação está vinculada ao ideal estético do totum ponere, ou seja, de construir uma totalidade, é nos ideais de ingenuidade e simplicidade do classicismo alemão que Nietzsche encontrará o estilo apropriado para que a filosofia realize sua meta: a formação.

Desta forma, ao propor a sua concepção de cultura como unidade de estilo artístico em todas as manifestações da vida de um povo, Nietzsche estabelece um nexo entre as noções de estilo e cultura e passará a avaliar a Alemanha de seu tempo a partir deste critério da unidade estilística. Neste capítulo final, procurou-se mostrar que as críticas que o jovem Nietzsche dirige aos filisteus da formação, bem como às instituições de formação alemãs, estão assentadas no relacionamento estabelecido entre estilo e formação. Desta maneira, percebe-se que o problema central do livro de David Strauss, A antiga e nova fé, consiste em um problema estilístico, uma vez que o livro não apresenta uma estrutura clássica, enfim, não se apresenta como uma totalidade, mas sua forma caótica e desordenada faz dele um livro eminentemente moderno.

Também no que se refere às instituições de formação, mostra-se que o incentivo à autonomia dos jovens escritores é o que faz com que a barbárie, isto é, a confusão caótica de todos os estilos, prolifere no âmbito da literatura alemã do tempo de Nietzsche, o que consiste num perigo para a língua alemã e, por conseguinte, para o

${ }^{251} \mathrm{Cf}$. SE/Co. Ext. III $\S 4$, KSA 1.363.

${ }^{252} \mathrm{SE} / \mathrm{Co}$. Ext. III $\S 2$, KSA 1.341. 
espírito alemão. Contra esta pseudoformação de caráter teórico, Nietzsche apresentará a proposta de uma formação clássica de caráter estético, o que consiste na educação do jovem através de um rigoroso estudo da língua alemã a partir do estilo simples e ingênuo dos autênticos clássicos alemães, de modo especial de Goethe e Schiller.

Em seguida, propôs-se mostrar de que modo o filósofo nietzschiano, na medida em que se afasta dos ideais teóricos da formação filisteia, prescinde do trabalho meramente especulativo da ciência para assumir-se como educador e formador. Tendo em vista o pressuposto de que a meta da filosofia é a formação do homem, e ao entender que esta formação tem um caráter intuitivo e não teórico, procurou-se apresentar a tese de que o estilo, para Nietzsche, consiste num instrumento fundamental para que a filosofia realize a sua meta formadora. Não qualquer estilo, mas o simples e ingênuo, tal como se pode observar na filosofia de Schopenhauer, o filósofo educador por excelência. 


\section{CONCLUSÃO}

Procurou-se, ao longo deste trabalho, defender a tese de que o estilo, para o jovem Nietzsche, é um importante instrumento por meio do qual a filosofia realiza a sua meta suprema, e como foi visto, não há nada com a divulgação de conhecimentos científicos e tampouco com a instrução (Belehrung) do indivíduo, mas sim com a formação (Bildung) do homem. Constatou-se que, ao pensar o tema do estilo à luz da reflexão sobre a formação, o jovem Nietzsche se fez herdeiro e continuador de uma corrente de ideias e pensadores que, quando rompe com a tradicional concepção normativa de estilo, puderam conceber o estilo como um princípio estético e ético fundamental para um conceito de educação (Erziehung) e formação do homem através da arte.

Confirmou-se esta hipótese a partir da reconstituição histórica do conceito de estilo desde a antiga retórica, em que este recebe um acento normativo, até a sua acepção moderna, revelou-se como a expressão singular e original de um indivíduo. Neste percurso, destacou-se a elaboração de um conceito histórico de estilo desenvolvido por Winckelmann, conceito que influenciou de maneira decisiva toda a história da arte. Com o decorrer do tempo, o estilo foi compreendido como um instrumento hermenêutico com o qual o historiador pode acessar o universo de significados de culturas e épocas passadas. Não obstante, observou-se que a reflexão winckelmanniana sobre o fenômeno do estilo ultrapassa os limites da mera especulação na medida em que propõe a imitação do estilo dos clássicos como uma via segura para a formação (Bildung) do artista moderno. Com a reflexão de Winckelmann sobre os efeitos do estilo grego clássico na formação do artista moderno, inaugurou-se na Alemanha uma nova concepção estético-moral de estilo ao despertar a antiga relação entre a educação e a arte no pensamento de homens como Goethe, Schiller e, como se pretendeu mostrar, do próprio Nietzsche.

Com Goethe, viu-se de que modo a valorização da subjetividade, "moléstia da atualidade”, promoveu a disseminação da barbárie no âmbito da ciência e do universo artístico alemão. Foi proposto que o conceito de estilo goethiano, à medida que se trata de um princípio estético ideal e objetivo, apresentou-se como um elemento fundamental para a formação estética do homem e, por conseguinte, para a superação da barbárie. Ao seguir a intuição de Goethe sobre o estilo, porém amparado pela segunda Crítica kantiana, mostrou-se como para Schiller, é compreendido num registro ao mesmo 
tempo estético e moral. O estilo, para ele, é a representação da liberdade na expressão artística, perspectiva que, como se viu, será explorada e radicalizada em suas Cartas acerca da educação estética do homem.

No presente trabalho, apresentou-se o jovem Nietzsche como um herdeiro e continuador deste movimento empreendido pelos clássicos alemães e que ele mesmo definiu como uma "luta pela formação". A favor desta hipótese, mostrou-se que, tal como seus mestres, Nietzsche entendeu o estilo como um princípio estético fundamental para a formação e educação estética do homem, quando se apresenta numa relação direta com a cultura (Kultur). No entanto, a despeito do papel de sucessor dos clássicos alemães, o jovem Nietzsche, num primeiro momento, afastar-se-á dos ideais classicistas na medida em que a Grécia que realmente lhe interessa é a Grécia pré-platônica e não a clássica; mas também porque a arte grega que lhe interessa é a tragédia, com um destaque para a música, não às artes plásticas.

A visão pessimista que o jovem Nietzsche apresentou em $A$ visão dionisíaca do mundo, bem como em $O$ nascimento da tragédia destoou da serenidade apolínea contida no ideal grego de Winckelmann, Goethe e Schiller. Nietzsche apresentou os princípios estéticos do dionisíaco e do apolíneo como estilos antagônicos, mas que uma vez reunidos produziram o maior evento da cultura grega antiga, a tragédia. Dessa forma, a constituição estilística do drama ático teve um aspecto fundamental para a formação do homem grego, bem como para a realização de sua cultura (Kultur). No entanto, os textos posteriores a $O$ nascimento da tragédia e os escritos preparatórios apresentaram uma virada no pensamento nietzschiano uma vez que já não se teve mais o estilo trágico.

Na Primeira Extemporânea o que se viu foi uma valorização do estilo ingênuo e simples dos clássicos em detrimento do estilo trágico, bem como a ideia de que é a língua alemã, e não a música, o fundamento para a formação do homem alemão. Nesta mesma obra, analisou-se de que modo os conceitos de estilo, formação e cultura se relacionaram. Ao definir a cultura como unidade de estilo artístico nas manifestações da vida de um povo, o jovem Nietzsche estabeleceu uma relação entre os conceitos de cultura e estilo que, como se viu, teve consequências diretas para a sua concepção de educação e formação. Nietzsche definiu como barbárie a falta de estilo ou a caótica proliferação de todos os estilos na Alemanha moderna e atacou os chamados filisteus da formação e as instituições de formação alemãs por promoverem um tipo de formação 
teórica que teve como meta a erudição e o acúmulo de saberes científicos, o que, segundo Nietzsche, tornou-se a fonte da barbárie alemã.

Contra este tipo de formação erudita e contra o modelo de educação propagado pelas instituições de ensino alemãs de seu tempo, Nietzsche apresentou a hipótese de uma formação intuitiva, um tipo de formação que teve no ideal classicista da educação estética do homem o caminho para a formação plena do homem e instituição de uma autêntica cultura alemã. A superação do estado de barbárie, para Nietzsche, dependeu da suplantação de uma equivocada formação, de caráter eminentemente teórico e abstrato, por uma formação intuitiva, que atuou na sensibilidade e obteve como fim o homem total, real e concreto.

Em sua Terceira Extemporânea, analisou-se o modo como Nietzsche compreendeu o papel do filósofo na formação do homem. Como indivíduo modelar ${ }^{253}, \mathrm{o}$ filósofo nietzschiano é um educador (Erzieher) por excelência. Entretanto, o jovem Nietzsche entendeu a tarefa de educar como algo radicalmente diferente e, num certo sentido, oposta à de instruir. Quando visou ao estatuto modelar do educador nietzschiano, o processo educativo jamais deveria ocorrer pela via da ilustração (Aufkärung) e da erudição científica, mas pelo contrário, dar-se-ia através da apreensão estética do modelo. Portanto, para o jovem Nietzsche, a educação (Erziehung) não teve como meta a erudição e o acúmulo de saberes científicos, mas sim a edificação estética e moral do indivíduo, o que significa realizar a sua plena formação (Bildung).

Como educador, o filósofo nietzschiano apresentou-se como um verdadeiro libertador e descobridor ${ }^{254}$, o que significou que ao educar teve a possibilidade de se livrar de tudo o que o impedia de acessar o seu ser mais íntimo e descobrir a si mesmo, pois, a concepção nietzschiana de educação se apresentou como próxima das noções de liberdade e emancipação. Não obstante, o filósofo nietzschiano também operou numa via propositiva, pois, uma vez emancipado, o indivíduo livrou-se para realizar de modo pleno a sua formação e, além de filósofo educador foi também o formador e modelador do homem.

Nessa análise da reflexão nietzschiana, a filosofia se mostrou como o meio pelo qual o filósofo realizou a educação e a formação do homem como uma totalidade, ou nas palavras de Nietzsche, como um sistema solar em que todas as forças girassem em torno e em prol de uma força central. Formar o homem como uma totalidade e em plena

${ }^{253}$ SE/Co. Ext. III § 3, KSA 1.350.

${ }^{254} \mathrm{SE} / \mathrm{Co}$. Ext. III $§ 1, \mathrm{KSA} 1.337$. 
harmonia consigo mesmo e com a cultura (Kultur), como a meta da filosofia e como a tarefa do filósofo. Logo, a formação e a cultura, para o jovem Nietzsche, apresentaramse como instâncias em permanente comunicação, pois para realizar uma autêntica formação é imprescindível ter uma verdadeira cultura, una e coesa, ou pelo menos que se forme segundo os preceitos de uma. Foi nisto que Nietzsche empreendeu uma volta aos gregos.

Se a formação estética do homem sempre foi tarefa do filósofo educador e a meta da filosofia, o estilo do discurso filosófico se apresentou como um elemento fundamental deste processo. Se o fim da filosofia não foi a produção de puro conhecimento, tampouco a erudição do indivíduo, então o discurso filosófico se afastou daquilo que convencionalmente foi instituído como um estilo obrigatório, ou seja, um estilo caracterizado pela ausência de elementos retóricos da linguagem. Quando se provocou um "efeito estético formador" no indivíduo, o filósofo se ocupou de uma linguagem que seja plena de estímulos, como a poética e, portanto, os elementos retóricos, como as metáforas e metonímias, foram imprescindíveis ao discurso filosófico. Contudo, na medida em que a ideia nietzschiana de formação consistiu na transfiguração do indivíduo como uma totalidade, o estilo a ser incorporado pelo discurso filosófico constituiu-se deste todo. O estilo mais apropriado ao discurso filosófico, segundo Nietzsche, foi o simples e ingênuo, tal como aquele que os clássicos alemães viram nos gregos. Simplicidade de estilo (Simplicität des Stil) e ingenuidade foram as principais características do gênio, o único que teve o privilégio de se expressar nesses temos. Dotado de capacidade para o simples e ingênuo, Schopenhauer foi, segundo Nietzsche, o gênio ingênuo do seu tempo. Por meio de um estilo sóbrio e simples, Schopenhauer fez com que a filosofia realizasse a sua meta formativa, eis o motivo de Nietzsche o considerou o seu mais importante educador.

Compreendido nesta assertiva estético-ética, o tema do estilo, no jovem Nietzsche, pode ser uma chave para compreender o sentido da peculiar arte estilística que o filósofo alemão desenvolveu em textos da maturidade, como em Humano, demasiado humano e Assim falava Zaratustra. Como instrumento ao mesmo tempo hermenêutico e pedagógico, o estilo permaneceu um elemento indispensável para que Nietzsche pensasse o discurso filosófico a partir de uma nova relação entre interpretação e formação. Como se ler um texto filosófico não significasse apenas assimilar ideias de um determinado autor, mas, mais do que isso, ser afetado pelo seu caráter. 


\section{REFERÊNCIAS}

\section{Obras de Nietzsche:}

NIETZSCHE, F. W. Sämtliche Werke. Kritische Studienausgabe. Hg. G. Colli e M. Montinari. Berlin: Walter de Gruyter, 1980, $15 \mathrm{v}$.

. Sämtliche Briefe. Kritische Studienausgabe. Hg. G. Colli e M. Montinari.

Berlin, New York: Walter de Gruyter, 1986, 8v.

. Obras incompletas. Trad. Rubens Rodrigues Torres Filho. São Paulo: Abril

Cultural, 2000. (Os pensadores).

. O nascimento da tragédia. Trad. J. Guinsburg. São Paulo: Companhia das

Letras, 1992.

. Obras completas V.1: escritos de juventude. Trad. Joan. B. Llinares, Diogo

Sánchez Meca e Luis E. de Santiago Guervós. Madrid: Techos, 2011.

. Fragmentos Póstumos (1869-1874). V. 1.Trad. Luis E. de Santiago Guervós.

Madrid: Techos, 2007.

.Les philosophes préplatoniciens. Trad. Olivier Sedeyn. Combas: éditions de l'éclat, 1994.

Ecce Homo. In: Basic Writings of Nietzsche. Trans. Walter Kaufmann, New

York: The Modern Library, 1992.

. Da retórica. Trad. Tito Cardoso e Cunha. Lisboa: Passagens, 2002.

\section{Obras complementares:}

ABEL, Günter. Consciência-Linguagem-Natureza: a filosofia da mente em Nietzsche. In: MARTON, S. (Org.). Nietzsche na Alemanha. São Paulo: Discurso editorial, p. 199-265, 2005 (Coleção Sendas e Veredas). 
ANDLER, C. Nietzsche, sa vie et sa pensée.Paris: Éditions Bossard, 1920.

ANTUNES, L.B.C. Ritmo e sonoridade na poesia grega antiga. São Paulo: Humanitas/FAPESP, 2011

ARISTÓTELES. Poética. Trad. Eudoro de Souza. Lisboa: Imprensa Nacional-Casa da Moeda, 2003.

BARK, K. FONTIUS, M. SCHLENSTEDT, D. (Orgs.). Ästhetische Grundbegriffe. Historisches Wörterbuch, Bd. 5.Stuttgart: Metzler, 2003.

BARRENECHEA, M.A. Nietzsche e a «Grande Política »: Memória, Educação e Criaçao de Valor. Ethica. Rio de Janeiro, n.1-vol.11, p. 93-110, 2004.

BATTEUX, C. As belas-artes reduzidas a um mesmo princípio. Trad. Natalia Maruyama. São Paulo: Humanitas, 2009.

BAYARD, E. L'artde reconnaîtreles styles: architecture - ameublement. Paris: Librairie Garnier Fr`eres, 1913.

BEHLER, E. Nietzsche und die romantische Metapher von der Kunst als Spiel, In: BATTS, M.S. et al. (orgs.). Echoes and influences of German Romanticism. Frankfurt/Meno: Peter Lang, 1987.

BELLORI, Giovanni Pietro. Observações de Nicolas Poussin sobre a pintura. In. LICHTENSTEIN, J (org.). A Pintura - vol.10: os gêneros pictóricos. Trad. Magnólia Costa. São Paulo: Ed. 34, 2006.

BLONDEL, Éric. Nietzsche: Le corps et la cultura. Paris: Presses Universitaires de France, 1986.

BOMBASSARO, Luiz Carlos. Paidéia e humanitas enquanto raízes do projeto formativo iluminista.In: CENCI, A.C.; DALBOSCO, C.A., MÜHL, E.H. (org.). Sobre filosofia e educação: racionalidade, diversidade e formação pedagógica. Passo fundo: Ed. Universidade de Passo Fundo, 2009. 
BORNHEIN, G. Introdução à leitura de Winckelmann. In: WINCKELMANN, J.J. Reflexões sobre arte antiga. Trad. Herbert Caro e Leonardo Tochtrop. Porto Alegre: Movimento, 1975.

BOTZ-BORNSTEIN, T. 'ART', Habitus, and style in Herder, Humboldt, Hamann, and Vossler: Hermeneutics and linguistics.Linguistic and Philosophical Investigations. New York, Volume 13, p. 121-139, 2014.

BRAIDA, Celso Reni. Filosofia da linguagem. Florianópolis: FILOSOFIA/EAD/UFSC, 2009.

BRANDÃO, Carlos Antônio Leite. Quid tum?: o combate da arte em Leon Battista Alberti. Belo Horizonte: Editora da Universidade Federal de Minas Gerais, 2000.

BRUFORD, W.H. The German Tradition of Self-Cultivation: 'Bildung' from Humboldt to Thomas Mann. Cambridge: Cambridge University Press, 2009.

BUFFON, Georges-Louis Leclerc. Discurso sobre o estilo. Tradução de Artur Morão. Covilhã: Universidade da Beira Interior, 2011. Disponível em: www.lusosofia.net/ textos/bufon_george_louis_discurso_sobre_o_estilo.pdf.

BURKE, E. Uma investigação filosófica sobre a origem de nossas ideias do sublime e do belo. Trad. Enid Abreu. Campinas: Editora da Unicamp, 2013.

BURCKHARDT, J. A cultura do renascimento na Itália: um ensaio. Trad. Sérgio Tellaroli. São Paulo: Companhia das letras, 2009. Reflexões Sobre a História. Trad. Leo Gilson Ribeiro. Rio de Janeiro: Zahar Editôres, 1961.

CASARES, M. O "giro retórico" de Nietzsche. Cadernos Nietzsche, São Paulo, n. 13, p. $7-36,2002$. 
CHAVES, Ernani. Cultura e política: o jovem Nietzsche e Jacob Burckhardt. Cadernos Nietzsche. São Paulo, n.9, p. 41-66, 2000.

CICERO, M.T. The Orations of Marcus Tullius Cicero. Translated by C. D. Yonge. London: George Bell \& Sons, 1903.

CLARK, Maudemarie. Nietzsche on truth and philosophy. Nova Iorque: Cambridge University Press, 2002.

CORBANEZI, E. Sobre a concepção relacional de linguagem em Nietzsche. Cadernos Nietzsche. São Paulo, n.34 - vol. 1, p. 167 - 187, 2014.

CRAWFORD, C. The beginnings of Nietzsche's theory of language. New York: de Gruyter, 1998.

. Nietzsche's great style: educator of the ears and of the heart. Nietzsche-Studien. Berlin, n.20, p. 210 - 237, 1991.

DELEUZE, Gilles. A lógica do sentido. Trad. Luis Roberto Salinas Fortes. São Paulo: Perspectiva, 2000.

Nietzsche. Tradução Alberto de Campos. Lisboa: Edições 70, 1994. . Nietzsche e a filosofia. Tradução Antonio M. Magalhães. Porto: Res Editora, [S.d.].

Pensamento nômade. In: MARTON, S. (org.) Nietzsche hoje?: Colóquio de Cerisy. Trad. Milton Nascimento e Sonia Salzstein Goldberg. São Paulo: Brasiliense, 1985. Pourparlers.Paris: Minuit,1990.

DERRIDA, Jacques. Gramatologia. Tradução Miriam Chnaiderman e Renato Janine Ribeiro. São Paulo: Perspectiva, 2006. . Eperons: les styles de Nietzsche. Paris: Flammarion, 1997. . A farmácia de Platão. Trad. Rogério Costa. São Paulo: Iluminuras, 1997. 
Políticas da amizade. Trad. Fernanda Bernardo. Porto: Campo das letras, 2003.

DIDEROT, D; D' ALEMBERT, J. Encyclopédie ou Dictionnaire Raisonné des Sciences, des Arts et des Métiers. Tome quinzième. Par une Société des Gens de Lettres. Neufchastel: Samuel Faulche et Compagnie, 1751-1765.

D'IORIO, Paolo. La naissance de la philosophie enfantée par l'esprit scientifique.In: NIETZSCHE, F. Les philosophes préplatoniciens. Trad. Olivier Sedeyn. Combas: éditions de l'éclat, 1994.

DILTHEY, W. Teoría de las concepciones del mundo. Madrid: Aliança Editorial, 1988.

DONATO, E. Donati ars maior. In: KEIL, H. (Ed.). Grammatici Latini, vol.IV. Leipzig: Teubner, 1855-1880.

DUFLO, C. O jogo:de Pascal a Schiller. Trad. Francisco Settineri e Patrícia Chittoni Ramos. Porto Alegre: Artmed Editora, 1999.

FRANCO, Maria Sylvia Carvalho. Linguagem e pensamento conservador: Aristóteles fonte da sociologia.Revista USP, São Paulo, v. 3, p. 113 - 142, 1989.

ECKERMANN, Johann P. Conversações com Goethe. Trad. Marina Leivas Bastian Pinto. Rio de Janeiro: Irmãos Pongetti Editores, 1950.

FINK, E. Spiel als Weltsymbol. Stuttgart: Kohlhammer, 1960.

FREZZATTI JR, Wilson Antonio. A fisiologia de Nietzsche: a superação da dualidade cultura/biologia. Ijuí: Ed. Unijuí, 2006.

FRONTEROTTA, F. Chronologia philosophorum. In: NIETZSCHE, F. Les philosophes préplatoniciens. Trad. Olivier Sedeyn. Combas: éditions de l'éclat, 1994.

GADAMER, Hans-Georg. Verdade e Método I: traços fundamentais de uma hermenêutica filosófica. Trad. Flavio Paulo Meurer. Petrópolis: Editora Vozes, 2005. 
GENTILE, C. Os gregos aprenderam aos poucos a organizar o caos: os conceitos de estilo e cultura na Segunda consideração extemporânea deF. Nietzsche. Cadernos Nietzsche. São Paulo, n. ${ }^{\circ}$ 27, p. 51-71, 2010.

GOETHE, J.W.; SCHILlER, F. Correspondência. Trad. Claudia Cavalcanti. São Paulo: Editora Hedra, 2011. . Goethes Gespräche mit J.P.Eckermann. Leipzig: Insel-Verlag, 1908. . A imitação simples da natureza, maneira, estilo. In: Escritos sobre arte. Trad. Marco Aurélio Werke. São Paulo: Humanitas, 2008. . Antigo e moderno. In: Escritos sobre arte. Trad. Marco Aurélio Werke. São Paulo: Humanitas, 2008a. Os anos de aprendizado de Wilhelm Meister. Trad. Nicolino Simone Neto. São Paulo: Editora 34, 2009.

GONTIER, Thierry. Nietzsche, Burckhardt et la 'question' de la Renaissance.Noesis, Paris, $\mathrm{n}^{\mathrm{o}} 10$, p. $49-71,2006$.

GONTIJO, L. Friedrich Nietzsche: "ideal clássico" e "ideal romântico" na tradição alemã. Cadernos Nietzsche.São Paulo, n. 22, p. 93 - 126, 2007.

GRIMM, J. e W. Deutsches Wörterbuch. Frankfurt am Main: Deutsches Taschenbuch, 1984.

GUERVÓS, Luis Enrique de Santiago. El poder de la palabra: Nietzsche y la retórica. In: NIETZSCHE, F. Escritos sobre retórica. Trad. Luis Enrique de Santiago Guervós. Madri: Trotta, 2000.

. "A dimensão estética do jogo na filosofia de F. Nietzsche", in cadernos Nietzsche, n. ${ }^{\circ}$ 28. São Paulo: Discurso Editorial, 2011, p. 49-72.

HABERMAS, J. O discurso filosófico da modernidade. Trad. Luiz Sérgio Repa e Rodnei Nascimento. São Paulo: Martins Fontes, 2000. 
HARVEY, P. Dicionário Oxford de Literatura Clássica. Rio de Janeiro: Jorge Zahar Editor, 1987.

HAVELOCK, E. Prefácio à Platão. Trad. Enid Abreu Dobránzsky. Campinas-SP: Papirus, 1996.

HEIDEGGER, Martin. NietzscheI.Trad. Marco Antônio Casanova. Rio de Janeiro: Forense Universitária, 2007.

. Conferências e escritos filosóficos. Trad. Ernildo Stein. São Paulo: Nova Cultural, 1991.(Os Pensadores) . Ensaios e conferência. Trad. Emanuel Carneiro Leão, Gilvan Fogel, Márcia Sá Cavalcante Schuback. Petrópolis: Vozes, 2006.

HELL, V. Friedrich Von Schiller: Théories dramatiques et structures esthétiques. Paris: Aubier, 1974.

HOOPS, J. Reallexikon der Germanischen Altertumskunde. Dreißigster Band.Berlin: Walter de Gruyter, 2005.

HORÁCIO. Arte poética. In: A Poética Clássica. Trad. Jaime Bruna. São Paulo: Editora Cultrix, 1997.

ITAPARICA, André. Nietzsche: estiloe moral. São Paulo: Discurso Editorial, 2002.

JASPERS, K. Nietzsche: introduction à sa philosophie. Trad. Henri Niel. Paris: Gallimard, 2000.

JÜNGER, E. Scritti politici e di guerra: 1919-1933. Gorizia: LEG, 2003.

KANT, I. Fundamentação da metafísica dos costumes. Trad. Valerio Rohden e António Marques. Rio de Janeiro: Forense Universitária, 1993. . Crítica da Faculdade do Juízo. Trad. Valerio Rohden e António Marques. Rio de Janeiro: Forense Universitária, 1995. 
Crítica da Razão Pura. Trad. Manuela Pinto dos Santos e Alexandre F.

Morujão. Lisboa: Fundação Calouste Gulbenkian, 1997.

KAPUST, D. Cicerón: El decorum y La moralidad de La retórica. Trad. Christian Felipe

Pineda Pérez. Praxis Filosófica, Cali, v.35, p. 257-282, julho/dez. 2012.

KOFMAN, Sarah. Nietzsche et la métaphore. Paris: Payot, 1972.

O/Os “conceitos"de cultura nas extemporâneas. In: MARTON, S. (org.)

Nietzsche hoje?: Colóquio de Cerisy. Trad. Milton Nascimento e Sonia Salzstein

Goldberg. São Paulo: Brasiliense, 1985.

KOSSOVITCH, Leon. Signos e poderes em Nietzsche. Rio de Janeiro: Azougue

Editorial: 2004.

KLAFKI, W. Neue Studien zur Bildungstheorie und Didaktik. Zeitgemässe Allgemeinbildung und kritisch-konstruktive Didaktik. Weinheim und Basel: Beltz Verlag, 2007.

LACOUE-LABARTHE, P. Le détour: Nietzsche et la réthorique. Poétique, Paris, v. II, p. $56-76,1971$.

LARGE, Duncan. Nosso maior mestre: Nietzsche, Burckhardt e o conceito de cultura. Cadernos Nietzsche. São Paulo, n..9, p. 3-39, 2000.

LEWIS, C; SHORT, C. A Latin Dictionary. Oxford: Clarendon Press, 1958.

LICHTENSTEIN, J (org.). A Pintura - vol.10: os gêneros pictóricos. Trad. Magnólia Costa. São Paulo: Ed. 34, 2006.

LOPES, Rogério A. Elementos de retórica em Nietzsche. São Paulo: Edições Loyola, 2006.

LOSURDO, Domenico. Nietzsche, il ribelle aristocrático. Torino: Bollati Boringhieri, 2002. 
LÖWITH, K. Nietzsche: philosophie de l'éternel retour du meme. Trad. Anne-Sophie Astrup. Paris: Hachette Littératures, 1991.

LUKÁCS, G. La destruction de la raison. Trad. Stanislas George, André Gisselbrecht e Eduard Pfrimmer. Paris: L’Arche Éditeur, 1958.

MACHADO, R. Nietzsche e o renascimento do trágico. Kriterium, Belo Horizonte, $\mathrm{n}^{\circ}$ 112, p. $174-182$, Dez/2005.

MARTON, Scarlett. Das forças cósmicas aos valores humanos. Belo Horizonte: Editora UFMG, 2010.

Silêncio, solidão.Cadernos Nietzsche,São Paulo, n.9, p. 79 - 105, 2000.

(org.). Nietzsche na Alemanha. São Paulo: Discurso Editorial, 2005.

(org.). Nietzsche pensador mediterrâneo: a recepção italiana. São Paulo:

Discurso Editorial, 2013.

(org.) Nietzsche hoje?: Colóquio de Cerisy. Trad. Milton Nascimento e Sonia

Salzstein Goldberg. São Paulo: Brasiliense, 1985.

Novas liras para novas canções: reflexões sobre a linguagem em Nietzsche. IDE, São Paulo, v. 30 (44), p. 32-39, junho-2007.

MAS, S. Introducción: La Grecia de Winckelmann. In: WINCKELMANN, J.J. Reflexiones sobre la imitación de las obras griegas em la pintura y la escultura. Trad. Salvador Mas. Madrid: Fondo de cultura econômica, 2008.

MAAS, Wilma Patrícia. A bela alma e a estética goethiana do símbolo. Viso - Caderno de estética aplicada. Rio de Janeiro, № 9, jul-dez 2010.

MATTÉI, Jean-François. A barbárie interior: ensaio sobre o i-mundo moderno. Trad. Isabel Maria Loureiro. São Paulo : Editora UNESP, 2002.

MECA, D.S. A evolución Del pensamiento de Nietzsche em sus escritos de juventud.In: NIETZSCHE, F. Obras completas: Volume I: escritos de juventud. Trad. Joan B. 
LLinares, Diego Sánchez Meca y Luis E. de Santiago Guervós. Madrid: Editorial Tecnos, 2011.

MONTINARI, M. Equívocos Marxistas. Cadernos Nietzsche. São Paulo, n.12, p. 33-52, 2002.

MORITZ. K. P. Signatur des Schönen und andere Schriften zur Begründung der Autonomieästhetik.Hamburg: Philo Phine Arts, 2009.

MOUTSOPOULOS, E. La musique dans l'ouvre de Platon. Paris: Presses Universitaires de France, 1959.

MÜLLER-LAUTER. O desafio Nietzsche. In: MARTON, S. (Org.). Nietzsche na Alemanha. São Paulo: Discurso editorial, p. 199-265, 2005 (Coleção Sendas e Veredas).

NABAIS, N.A metafísica do trágico. Lisboa: Relógio D’Água Editores, 1997.

NASSER, E. O destino do gênio e o gênio enquanto destino: o problema do gênio no jovem Nietzsche. Cadernos Nietzsche. São Paulo, n.30, 287-302, 2012.

NASSER, N. A doutrina do ethos na música. Boletim do CPA, Campinas, n. ${ }^{\circ} 4$, p. 241254, jul./dez. 1997. NUNES, B. Introdução à filosofia da arte. São Paulo: Editora Ática, 2002.

NEHAMAS,A. Nietzsche: life as literature. Cambridge, Massachusetts: Harvard University Press, 1985.

NIEMEYER, C. (org.). Léxico de Nietzsche.Trad. André M. Garcia, Ernani Chaves, Fernando Barros, Jorge Luiz Visenteiner, William Matiolli. São Paulo: Edições Loyola, 2014.

NUNES, B. Introdução à Filosofia da Arte. São Paulo: Ática, 2002.

PALMER, R. C. Oxford Latin Dictionary. Oxford: Clarendon Press,1968. 
PIMENTA, Olímpio. Sobreo Nascimento da Tragédia. In: ALVES Jr., D.G.(Org.). Os destinos do trágico: arte, vida, pensamento. Belo Horizonte: Autêntica/FUMEC, 2007.

PLATÃO. A república.Trad. Maria Helena da Rocha Pereira. Lisboa: Fundação Calouste Gulbenkian, 1996.

RINGER, F. O declínio dos mandarins alemães - A comunidade acadêmica alemã, 1890-1933. Trad. Dinah de Abreu Azevedo. São Paulo: Edusp, 2000.

RITTER, J. ; GRÜNDER, K. (Orgs.). Historisches Wörterbuch der Philosophie, Bd.10. Basel: Schwabe, 1989.

RUBIRA, L. Nietzsche: do eterno retorno do mesmo à transvaloração de todos os valores. São Paulo: Barcarolla/Discurso editorial, 2010.

RUSSELL, B. The history of western philosophy. London: George Allen \& Unwin ltd, 1947.

SAFATLE, V. Nietzsche e a ironia em música. Cadernos Nietzsche.São Paulo, n. 21, p.7-28, 2006.

SAUERLÄNDER, W. From stilus to Style: Reflections on the Fate of a Notion. Art History, Hamilton, v. 6, n.3, p. 253-270, September 1983.

SCHAPIRO, M. Style, Artiste et société. Trad. Daniel Arasse. Paris: Éditions Gallimard, 1982.

SCHILLER, F. Kallias ou sobre a beleza: a correspondência entre Schiller e Körner, janeiro-fevereiro 1793. Trad. Ricardo Barbosa. Rio de Janeiro: Jorge Zahar Ed., 2002.

. Schillers Briefwechsel mit Körner. Von 1784 bis zum Tode Schillers. Vol 1. Leipzig: Veit, 1874. 
Über die ästhetische Erziehung des Menschen in einer Reihe von Briefen: mit den Augustenburger Briefen. Stuttgart: Reclam, 2008.

. A educação estética do homem numa série de cartas. Trad. Roberto Schwarz e

Márcio Suzuki. São Paulo: Iluminuras, 2002.

. Poesia ingênua e sentimental. Trad. Márcio Suzuki. São Paulo: Iluminuras, 1991.

. Fragmentos das preleções sobre estética do semestre de inverno de 1792-93.

Trad. Ricardo Barbosa. Belo Horizonte: Editora UFMG, 2004.

SCHOPENHAUER, Arthur. O mundo como vontade e representação (III Parte). Trad.

Wolfgang Leo Maar, Maria Lúcia Mello, Oliveira Cacciola. São Paulo: Nova Cultural, 2000. (Os Pensadores).

O Mundo como Vontade e Representação. Trad. Jair Barbosa. São Paulo:

Editora Unesp, 2005.

. Parerga y paralipómena II.Trad. Pilar López de Santa María. Madrid: Editorial

Trotta, 2009, p. 527.

SILVA JR, I. Em busca de um lugar ao sol: Nietzsche e a cultura alemã. São Paulo: Discurso Editorial, 2007.

SILVA, J. A. O fragmento e a síntese. São Paulo: Editora Perspectiva, 2003.

SOCA. R. La fascinante historia de las palabras,Tomo I. Río de Janeiro: Asociación Cultural Antonio de Nebrija, 2004.

SOHM, P. Maniera and the absent hand: Avoiding the etymology of style. RES: Anthropology and Aesthetics, Harvard, n.36, p.100-124, Autumn, 1999.

SPINELLI, M. Sobre as diferenças entre éthos com épsilon e êthos com eta. Trans/Form/Ação. São Paulo, 32(2), p. 9-44, 2009. 
STEGMAIER, W. As linhas fundamentais do pensamento de Nietzsche: coletânea de artigos 1985-2009.Trad. Vários tradutores. Petrópolis: Editora Vozes, 2013.

STEINER, Deborah. Images in mind: Statues in Archaic and Classical Greek Literature and Thought. Princeton: Princiton University Press, 2001.

STRAUSS, D.F. La antigua y la nueva fe.Trad. Ramón Ibáñez. Madrid: F. Sempere y Compañía, Editores, 1900.

TORRES, Rubens R. Ensaios de filosofia ilustrada. São Paulo: Editora Brasiliense, 1987.

TRINGALI, D. A arte poética de Horácio. São Paulo: Musa Editora, 1993.

VATIMO, G. Diálogo com Nietzsche. Ensaios 1961 - 2000. Trad. Carmen Revilla. Barcelona: Paidós, 2002.

VAZ, H. C. de Lima. Escritos de Filosofia IV: Introdução à ética filosófica 1. São Paulo: Ed. Loyola, 1999.

VIEHAUS, R. Geschichtliche Grundbegriffe. Historisches Lexikon zur politischesozialen Sprache in Deutschland, 7v., orgs. Otto Brunner, Werner Conze e Reinhart Koselleck, v. 1, Stuttgart: Klett-Cotta, 4 ed., 1992, p. 508-551.

WAGNER, R. Beethoven. Trad. Theodemiro Tostes. Porto Alegre: L\&PM, 1987.

WEBER, José Fernando. Formação (Bildung), educação e experimentação em Nietzsche. Londrina: Eduel, 2011.

WERLE, M.A. Winckelmann, Lessing e Herder: estéticas do efeito? Trans/Form/Ação. São Paulo, n.23, p. 19-50, 2000. A relação entre a estética de Hegel e a poesia de Goethe. Discurso. São Paulo, n. 32, p. $161-92,2001$. . A aparência sensível da ideia: estudos sobre a estética de Hegel e a época de Goethe.São Paulo: Edições Loyola, 2013. 
WILCOX, John T. Nietzsche scholarship and the correspondence theory of truth: the Danto case. Nietzsche-Studien. Berlin,n.15, p. 337-357, 1986.

WINCKELMANN, J.J. Reflexiones sobre la imitación de las obras griegas em la pintura y la escultura. Trad. Salvador Mas. Madrid: Fondo de cultura econômica, 2008.

Reflexões sobre arte antiga. Trad. Herbert Caro e Leonardo Tochtrop. Porto Alegre: Movimento, 1975.

. Essays on the philosophy and history of art. Vol. III. Trans. Curtis Bowman. New York: Continuum, 2005.

_. On Grace.In: Reflections on the paiting and sculpture of the greeks.London:Henry Fusseli,1765.

WÖLFFLIN, H. Conceitos Fundamentais da História da Arte. São Paulo: Martins Fontes, 1982.

WOTLING, P. Nietzsche e o problema da civilizaçao. Trad. Vinícius de Andrade. São Paulo: Editora Barcarolla, 2013.

ZEDLER, J.H. Großes vollstandiges Universallexikon, Bd.40. Leipzig: Bernhard Christoph Breitkopf, 1744.

ZOURABICHVILI, François. O Vocabulário de Deleuze. Trad. André Telles. Rio de Janeiro: Relume Dumara, 2004. 